\title{
STUDIES ON THE DISTRIBUTION OF APPENDICULARIANS AND SOME THALIACEANS OF THE NORTH PACIFIC, WITH SOME MORPHOLOGICAL NOTES
}

\author{
$\operatorname{AUTHOR}(\mathrm{S})$ : \\ Tokioka, Takasi
}

\section{CITATION:}

Tokioka, Takasi. STUDIES ON THE DISTRIBUTION OF APPENDICULARIANS AND SOME THALIACEANS OF THE NORTH PACIFIC, WITH SOME MORPHOLOGICAL NOTES.

PUBLICATIONS OF THE SETO MARINE BIOLOGICAL LABORATORY 1960, 8(2): 351-443

\section{ISSUE DATE:}

1960-12-20

URL:

http://hdl.handle.net/2433/174644

RIGHT: 


\title{
STUDIES ON THE DISTRIBUTION OF APPENDICULARIANS AND SOME THALIACEANS OF THE NORTH PACIFIC, WITH SOME MORPHOLOGICAL NOTES ${ }^{1)}$
}

\author{
TAKASI TOKIOKA
}

Seto Marine Biological Laboratory, Sirahama

With 16 Text-figures and 36 Tables

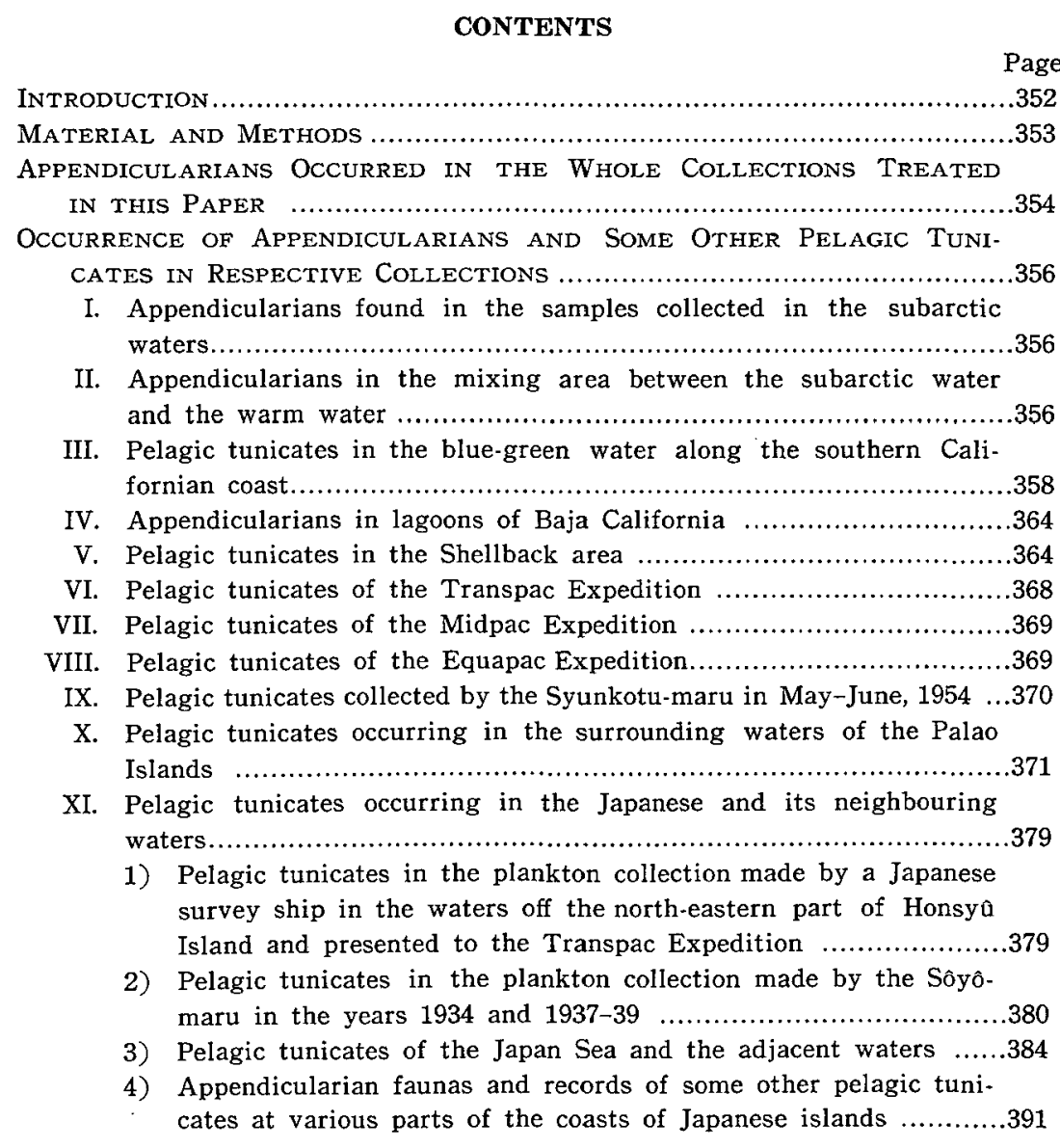

1) Contributions from the Seto Marine Biological Laboratory, No. 357.

Publ. Seto Mar. Biol. Lab., VIII (2), 1960. (Article 27) 
XII. Occurrence of pelagic tunicates in the waters adjoining to the North Pacific.

1) Pelagic tunicates of the Siboga area ................................393

2) Pelagic tunicates of the Arafura Sea ..............................394

3) Pelagic tunicates in the waters off eastern Australia................396

4) Pelagic tunicates of the South Pacific .................................397

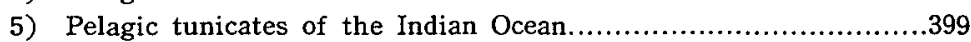

XIII. Pelagic tunicates of the Altantic .......................................402

(a) The Atlantic Ocean ................................................402

(b) The Mediterranean Sea .............................................408

(c) Tne Gulf of Mexico..........................................411

XIV. General distributional aspect of pelagic tunicates in the North Pacfic...413

1) Vertical distribution of appendicularians .........................413

2) Areas of abundant occurrences of appendicularians in the warmwater regions of the North Pacific

3) Constitution of the appendicularian population ......................415

4) Distribution of doliolums........................................419

5) Distribution of salps .............................................422

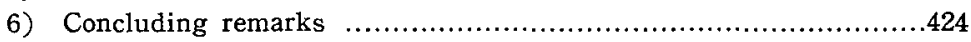

Morphotogical Notes on SOME APPENDICULARIANS AND Thaliaceans...425

1) Colouration of some appendicularians ...................................425

2) Colouration of some thaliaceans ......................................426

3) Subchordal cells in some species of Oikopleura (Vexillaria)..............426

4) Size of some appendicularians........................................427

5) Morphology of some appendicularians ................................428

6) Characteristics of Thalia democratica var. orientalis ......................429

7) Parasitic organism of appendicularians ..............................430

SUMMARY AND CONCLUSIONS...................................................430

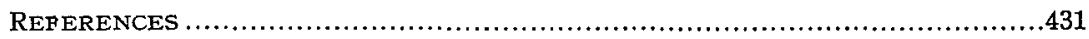

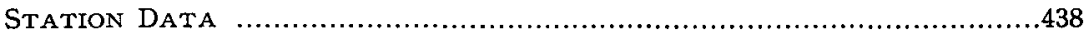

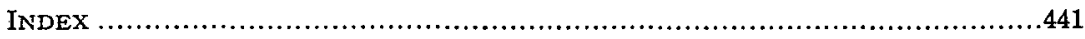

APPENDIX TABLES 1-19 (Sheets folded at the end)

\section{INTRODUCTION}

From the standpoint of the distribution of chaetognaths of the North Pacific, I proposed the possibility of separating the bedoti-water as a distinct water mass from the vast far oceanic pacifica-dominant water mass (1959). Besides, I tried to distinguish the enflata-dominant equatorial water mass in the same paper. However, in order to ascertain these ideas, it is very necessary to find out some plankton animals other than chaetognaths, which are distributed in similar manners as in the above-mentioned chaetognaths. For this reason, I am going to analyse the distribution of appendicularians of the North Pacific in the same way as that adopted in my former study of chaetognaths in 1959. Namely, predominant species are selected out at first, ratios among these species are calculated and then the distribution of ratio values is studied. In the warm water of the North Pacific, Oikopleura longicauda and $O$. fusiformis can be taken up as predominant forms as seen clearly in Table 1 showing the abundance of respective 
species in the collections treated in the present paper. Thus, the ratio $\mathrm{F} / \mathrm{L}(=$ O. fusiformis/O. longicauda) was calculated about each available sample. By the way, distributions of Doliolum denticulatum, Doliolum nationalis and Dolioletta gegenbauri var. tritonis in the North Pacific are studied in this paper in relation to various water masses. Further, a notice was paid on the distribution of Thalia democratica var. orientalis to find out whether or not the distribution of this variety and that of the typical form are segregative.

Although I used many data published by various authors together with my own unpublished ones to build up the general outline of the distribution of appendicularians and some thaliaceans of the North Pacific, most parts of the data were obtained while I was staying at the Scripps Institution of Oceanography in 1956-57 to study a part of the vast collection of plankton samples kept there. Consequently, this paper might be regarded as the third paper dealing with the results of my appendicularian studies made at that laboratory. All of my own unpublished data, mentioned above, are shown in appended tables at the end of this article. Because there have not yet been any papers in which the distribution of appendicularians is discussed in the scale of the North Pacific, this paper might be regarded as a preliminary report on this subject, although there remain still some wide areas, where the appendicularian fauna has never been studied. Besides the distributional studies, some short morphological notes on several species will be found in later pages.

Before going further, I want to express my hearty thanks to the staff of the Scripps Institution of Oceanography for granting me the favour of a seat at the laboratory for a year, especially to Prof. M. W. JoHnson for his kindness in providing facilities and also to the Rockefeller Foundation for a postdoctoral fellowship.

\section{MATERIAL AND METHODS}

The material treated in this article comprises all of the seven collections mentioned in my previous paper (1959) on the North Pacific chaetognaths and a few other collections which are described fully in respective chapters where the data on these collections are published for the first time. Here, I have to express my hearty thanks again to Prof. Fred B PhLEGer and members of the Foraminifera Laboratory of the Scripps Institution of Oceanography for their kindness in allowing me to examine the plankton samples collected from Scammon's and Manuela lagoons and to quote some of the hydrographical data in this paper, as those samples included a number of Oikopleura dioica and thus they offered very important data for the distribution of this species.

The whole contents were examined with a magnification of $30 \times$ or under the microscope with more higher magnifications, when the samples collected with small nets were treated. Every individual of each species was identified carefully 
and counted. However, only a quater of the contents was examined in this way, when the large net samples were dealt with.

It is clear that the present material is not satisfactory as to the evenness of the distribution of sampling stations and times in respective areas referred to. Moreover, there is another difficulty which cannot be overcome easily. As the body consistency of appendicularians is not so tough and ready to be easily mutilated, lots of specimens are of ten found damaged and cannot be identified. The proportion of these damaged specimens to the whole appendicularian population is usually much larger in respective samples than in the cases concerning chaetognaths. If the damaged specimens occurred in a certain proportion to the whole population in respective species, then the existence of such unidentified specimens would not be a significant obstacle in discussing the quantitative distribution of respective species. Actually, however, some species can be identified very exactly even in a heavily damaged condition, these include Fritillaria pellucida, $F$. formica and sometimes some oikopleurids belonging to the subgenus Vexillaria having a tough tail-musculature with subchordal cells; while some other oikopleurids belonging to the subgenus Coecaria having a rather delicate tailmusculature without any subchordal cells and such fritillarians as $F$. haplostoma can hardly be identified with certainty in a damaged state. It is very probable that latter forms are damaged more easily than former ones. Thus, the distribution of damaged and unidentified individuals among species cannot be parallel to that of identified individuals. And yet, this discrepancy can never be adjusted in any way. For these reasons, the acuracy of the ratio F/L, percentages of respective species and other values estimated on these should be lowered for some extent. It seems quite impossible to assess the extent, some people might consider it is scarcely possible to deduce any trends from the arrangement of such values, but I believe the trends found in the distribution of those values are reliable when abundant data are treated. To do with many data seems to be the only solution for the above-mentioned difficulty. In computing percentages, ratios and means, fractions less than $1 / 2$ were disregarded and the rest were counted as units.

\section{APPENDICULARIANS OCCURRED IN THE WHOLE COLLECTIONS TREATED IN THIS PAPER}

Forty forms of appendicularians were identified in the present material. They are:

1. Oikopleura (Coecaria) longicauda (VogT), 1854

2. Oikopleura (Coecaria) intermedia LoHMANN, 1896

3. Oikopleura (Coecaria) fusiformis FoL, 1872

4. Oikopleura (Coecaria) fusiformis f. cornutogastra (AIDA), 1907 
5. Oikopleura (Coecaria) gracilis LohmanN, 1896

6. Oikopleura (Coecaria) graciloides Lohmann \& Bückmann, 1924

7. Oikopleura (Vexillaria) dioia Fol, 1872

8. Oikopleura (Vexillaria) rufescens Fol, 1872

9. Oikopleura (Vexillaria) parva. Lohmann, 1896

10. Oikopleura (Vexillaria) cophocerca Gegenbaur, 1855

11. Oikopleura (Vexillaria) albicans (LEUCKART), 1854

12. Oikopleura (Vexillaria) labradoriensis LOHMANN, 1892

13. Megalocercus huxleyi (RITTER), 1905

14. Megalocercus abyssorum $\mathrm{CHUN}_{\mathrm{H},} 1888$

15. Stegosoma magnum (LANGERHANS), 1880

16. Folia gracilis Lohmann, 1892

17. Pelagopleura verticalis (LOHMANN), 1914

18. Althoffia tumida LoHMANN, 1896

19. Sinisteroffia scrippsi TокIOKA, 1957

20. Bathochordaeus sp.

21. Fritillaria (Acrocercus) haplostoma FoL, 1872

22. Fritillaria (Acrocercus) abjornseni LohmanN, 1909

23. Fritillaria (Acrocercus) arafoera ТокіокА, 1956

24. Fritillaria (Acrocercus) aberrans LoHMANN, 1896

25. Fritillaria (Acrocercus) formica f. digitata Lohmann \& Bückmann, 1926

26. Fritillaria (Acrocercus) fraudax LoHmans, 1896

27. Fritillaria (Acrocercus) gracilis LoHManN, 1896

28. Fritillaria (Acrocercus) charybdae Lohmans, 1899

29. Fritillaria (? Acrocercus) pacifica TokIoKA, 1958

30. Fritillaria (Eurycercus) pellucida (BuScH), 1851

31. Fritillaria (Eurycercus) borealis f. typica (LoHmanN), 1900

32. Fritillaria (Eurycercus) borealis f. intermedia (LOHMANN), 1905

33. Fritillaria (Eurycercus) borealis f. sargassi (LohmanN), 1896

34. Fritillaria (Eurycercus) megachile FoL, 1872

35. Fritillaria (Eurycercus) tenella Lohmann, 1896

36. Fritillaria (Eurycercus) venusta LoHmanN, 1896

37. Tectillaria fertilis (LoHmanN), 1896

38. Tectillaria taeniogona (ТокіокA), 1957

39. Appendicularia sicula FoL, 1874

40. Kowalevskaia tenuis FoL, 1872

All the specimens of Fritillaria (Acrocercus) formica FoL, 1872 were represented by forma digitata LOHMANN \& BücKMANN in the present material. The abundance of respective species in each collection is shown in the Table 1 , besides Tables 3, 4, 7-11, 13-22 are needed for making the general outline of the appendicularian distribution in the North Pacific. The following eight species 
O. longicauda

O. fusiformis

O. rufescens

Frit. borealis f. sargassi

Frit. pellucida

Steg. magnum

$O$. cophocerca

M. huxleyi

are considered to be common ones throughout the eight collections from the warm water regions of the Indo-Pacific, especially first three are outstanding. It is very clear that $O$. longicauda is the commonest species and $O$. fusiformis may be said as following it. Thus, the ratio between these two species (F/L) was calculated as to respective samples and the distribution of this ratio was studied.

\section{OCCURRENCE OF APPENDICULARIANS AND SOME OTHER PELAGIC TUNICATES IN RESPECTIVE COLLECTIONS}

\section{APPENDICULARIANS FOUND IN THE SAMPLES COLLECTED IN THE SUBARCTIC WATERS}

(Appendix Table 1)

Only two species, O. labradoriensis and Frit. borealis f. typica, occurred in 34 samples collected in the subarctic waters during the Transpac-Expedition; the former was much more abundant than the latter. $O$. labradoriensis was very abundant at Stations TP 25 and TP 37 and pretty dense at Stations TP 30 and TP 44, while Frit. borealis f. typica was fairly abundant at Station TP 42. This seems to strengthen the possibility that $O$. chamissonis MERTENS 1831, an insufficiently described form from the Bering Straits might be identical with $O$. labradoriensis.

\section{APPENDICULARIANS IN THE MIXING AREA BETWEEN THE SUBARCTIC WATER AND THE WARM WATER}

(Table 2)

In the Transpac-Expedition samples from the mixing area between the subarctic and the warm water, $O$. longicauda was much more abundant then $O$. fusiformis which occurred only rarely. The component of the appendicularian population in each sample including $O$. labradoriensis is shown below in Table 2 . This shows evidently that $O$. longicauda is predominant among warm water species in both eastern and western mixing areas. The collection made by the Japanese survey ship and presented to the Transpac Expedition party contains only a single sample in which $O$. labradoriensis is found; forty $O$. longicauda and a 


\begin{tabular}{|c|c|c|c|c|c|c|c|c|c|}
\hline Collections & JS & $\mathrm{TP}$ & SB & MP & EQP & $\mathrm{CP}$ & $\mathrm{AR}$ & $\mathrm{CI}$ & Total \\
\hline O. longicauda & 6900 & 3828 & 3400 & 1809 & 2200 & 1312 & $\overline{4560}$ & 4400 & 28409 \\
\hline O. intermedia & - & 6 & 96 & 33 & 40 & 42 & 32 & 72 & 321 \\
\hline O. fusiformis & 962 & 2080 & 474 & 486 & 700 & 2492 & 319 & 1134 & 8647 \\
\hline $\begin{array}{l}\text { O. fusiformis } \\
\text { f. cornutogastra }\end{array}$ & 16 & $*$ & 10 & 9 & $*$ & - & 836 & 8 & $* 879$ \\
\hline O. gracilis & - & 16 & 8 & - & - & - & - & 64 & 88 \\
\hline O. graciloides & 32 & 120 & 51 & 9 & 40 & - & - & 12 & 264 \\
\hline O. dioica & 63 & 240 & 19 & 12 & - & - & 432 & 105 & 871 \\
\hline O. rufescens & 371 & 528 & 511 & 689 & 700 & 671 & 1300 & 803 & 5573 \\
\hline O. parva & - & 24 & 42 & 7 & - & 7 & $\overline{2}$ & 115 & 197 \\
\hline O. cophocerca & 10 & 174 & 553 & 588 & 160 & 36 & 160 & 464 & 2145 \\
\hline O. albicans & - & 120 & 264 & 77 & 20 & - & - & 135 & 616 \\
\hline O. labradoriensis & 25 & 372 & - & 二 & - & - & - & - & 397 \\
\hline M. huxley $i$ & - & 16 & 126 & 200 & 160 & 1204 & 27 & 36 & 1769 \\
\hline M. abyssorum & - & - & * & 18 & - & - & - & - & $* 18$ \\
\hline Steg. magnum & 78 & 145 & 174 & 192 & 180 & 810 & 9 & 620 & 2208 \\
\hline Folia gracilis & - & - & * & 一 & - & - & - & - & * \\
\hline P. verticalis & - & - & 42 & - & ?* & $? 4$ & - & 45 & $* 91$ \\
\hline Alth. tumida & - & 1 & 39 & 2 & ?* & 25 & - & - & $* 67$ \\
\hline Sin. scrippsi & - & - & 8 & - & - & - & - & - & 8 \\
\hline Bathochordaeus sp. & - & - & * & - & $*$ & - & - & - & * \\
\hline Frit. haplostoma & 28 & 80 & 31 & 32 & 40 & 44 & 80 & 112 & 441 \\
\hline Frit, abjornseni & - & 2 & 二- & - & 二 & - & 10 & - & 12 \\
\hline Frit. arafoera & 5 & $\div$ & 二 & 二 & - & - & 2 & - & 7 \\
\hline Frit. aberrans & - & 4 & 29 & 28 & $*$ & - & - & - & $* 61$ \\
\hline $\begin{array}{l}\text { Frit. formica } \\
\text { f. digitata }\end{array}$ & 224 & 81 & 52 & 63 & 80 & 172 & 25 & 108 & 805 \\
\hline Frit. fraudax & 5 & - & $*$ & 24 & 40 & - & - & 8 & $* \overline{77}$ \\
\hline Frit. gracilis & - & - & $*$ & * & 40 & - & - & 28 & $* 68$ \\
\hline Frit. charybdae & - & - & * & - & 二 & - & 二 & - & * \\
\hline Frit. pacifica & - & 1 & 15 & - & 80 & - & - & - & 96 \\
\hline Frit. pellucida & 26 & 154 & 150 & 100 & 1840 & 256 & 8 & 114 & 2648 \\
\hline $\begin{array}{l}\text { Frit. borealis } \\
\text { f. typica }\end{array}$ & 10 & 252 & - & - & - & - & - & $\rightarrow$ & 262 \\
\hline $\begin{array}{l}\text { Frit. borealis } \\
\text { f. intermedia }\end{array}$ & - & 一 & 4 & - & $*$ & - & - & 12 & $* 16$ \\
\hline $\begin{array}{l}\text { Frit. borealis } \\
\text { f. sargassi }\end{array}$ & 638 & 610 & 99 & 490 & 320 & 126 & 1120 & 462 & 3865 \\
\hline Frit. megachile & 10 & 16 & * & 6 & 40 & 35 & - & 16 & $* 123$ \\
\hline Frit. tenella & - & - & 54 & 49 & 640 & - & - & - & 743 \\
\hline Frit. venusta & - & 二 & 44 & 6 & 160 & 22 & 二 & - & 232 \\
\hline T. fertilis & 63 & 34 & 15 & $*$ & 20 & - & 2 & - & $* 134$ \\
\hline T. taeniogona & - & - & 15 & - & 二 & - & - & - & 15 \\
\hline App. sicula & 96 & 63 & $*$ & $*$ & - & $\cdots$ & 464 & 45 & $* 668$ \\
\hline K. tenuis & $*$ & * & $*$ & - & - & 143 & 2 & 一 & $* 145$ \\
\hline Oikopleurids damaged & 444 & 1008 & 3700 & 3690 & 2600 & 2500 & 384 & 1022 & 15348 \\
\hline Fritillarians damaged & 33 & 54 & 40 & 84 & 80 & 21 & 4 & 108 & 424 \\
\hline Number of samples & 19 & $\overline{97}$ & 48 & 56 & 5 & 28 & 55 & 26 & 334 \\
\hline
\end{tabular}

Table 1. The value Frequency of Occurrence $\times$ Mean Percentage of each species in respective collections made in the warm water regions of the Indo-Pacific.

AR-The collection from the Arafura Sea, CI...The central part of the tropical Indian Ocean, CP...The Central Pacific surveyed by the Syunkotu-Maru, EQP...The collection of the Equapac Expedition, JS...The collection made by the Japanese Survey Ship in the offshore waters off the north-eastern part of Honsy $\hat{a}$ Island, Japan; MP...The

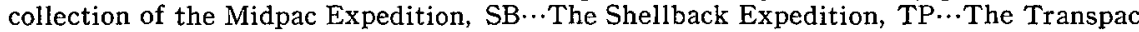
Expedition. *...The value less than 1, in the last column it indicates that the numerals show the total of values excluding those less than 1 . 
single damaged and unidentified specimen were found in this sample (see J3 of Appendix Table 18). In many samples collected by the vertical haul from $50-100 \mathrm{~m}$ to the surface in the Japan Sea, were found considerable numbers of O. labradoriensis, too. In these samples, besides O. labradoriensis, O. longicauda and $O$. dioica were found most frequently as seen later in Tables $16-18$ in the

\begin{tabular}{|c|c|c|c|c|c|c|c|c|c|c|c|c|}
\hline Stations & $\begin{array}{l}\mathrm{TP} \\
18\end{array}$ & $\begin{array}{l}\text { TP } \\
26\end{array}$ & $\begin{array}{l}\text { TP } \\
33\end{array}$ & $\begin{array}{l}\mathrm{TP} \\
51\end{array}$ & $\begin{array}{l}\text { TP } \\
52\end{array}$ & $\begin{array}{c}\mathrm{TP} \\
57 \mathrm{~A}\end{array}$ & $\begin{array}{c}\mathrm{TP} \\
58 \mathrm{~A}\end{array}$ & $\begin{array}{l}\text { TP } \\
61\end{array}$ & $\begin{array}{l}\mathrm{TP} \\
67\end{array}$ & $\begin{array}{l}\text { TP } \\
68\end{array}$ & $\begin{array}{l}\mathrm{TP} \\
73\end{array}$ & 11 samples \\
\hline o. labradoriensis & 4 & 2 & 5 & 25 & 14 & 13 & 5 & 5 & 5 & $\mathbf{1}$ & 2 & F.O. $-100 \%$ \\
\hline O. longicauda & & 1 & 1 & 12 & 11 & 21 & 4 & 10 & 38 & 28 & 36 & 91 \\
\hline o. fusiformis & & & & & 10 & & 10 & & & & & 18 \\
\hline o. dioica & & & & & & & & & & & 21 & 9 \\
\hline $\begin{array}{l}\text { Oikopleurids } \\
\text { damaged }\end{array}$ & & & & 2 & 2 & 1 & 1 & & & & 3 & 45 \\
\hline Frit. pellucida & 18 & & & & 1 & & & & & & & 18 \\
\hline $\begin{array}{l}\text { Frit. borealis } \\
\text { f. typica }\end{array}$ & & & & 14 & 3 & 2 & 576 & & & & & 36 \\
\hline
\end{tabular}

Table 2. Occurrence of appendicularians in the Transpac-Expedition samples collected in the mixing area between the subarctic water and the warm water.

chapter concerning the appendicularian fauna of the Japan Sea. In southern part of this sea, however, the distribution of $O$. labradoriensis seemed frequently to be segregated vertically from those of $O$. longicauda and other warm water forms, namely the former was found confined to the submerged cold water mass, while the latter were abundant in the surface warm water.

\section{PELAGIC TUNICATES IN THE BLUE-GREEN WATER ALONG THE SOUTHERN CALIFORNIAN COAST}

\section{(App. Tables 2 and 3, Table 3 and Text-fig. 1)}

Eight species of appendicularians occurred in the nineteen plankton samples collected March 12-13, 1956 in the coastal blue-green water along the Californian coast from San Diego to Long Beach, when a small net, $17 \mathrm{~cm}$ in the mouth diameter, was towed from $20-40 \mathrm{~m}$ to the surface. $O$. dioica occupied the largest part of the appendicularian population and Frit. borealis f. typica did also a significant part. Small numbers of $O$. longicauda were found in samples collected near the boundary between the blue-green water and the more offshore blue water. The occurrence of a few $O$. labradoriensis together with a considerable number of Frit. borealis f. typica shows evidently that the water of the surveyed area was influenced by the subarctic water carried by the California Current at that time and the predominance of $O$. dioica indicates that the neritic nature was highly retained there at the same time (App. Table 2).

$$
-136-
$$


The 35 plankton samples collected off San Diego with a similar small net and stored at the Scripps Institution contained a large number of O. longicauda and a pretty amount of $O$. dioica (App. Table 3). Here occurred a significant number of $O$. fusiformis, although $\mathrm{F} / \mathrm{L}$ being only 0.03 . A few Frit. borealis $\mathrm{f}$. sargassi together with f. typica were found in this collection. Thus, it is clear that the water of the surveyed area was the mixture of the neritic water and the warm oceanic water and partly affected by the subarctic influx. Of Thaliacea, Doliolum nationalis and Dolioletta gegenbauri var. tritonis were found in this collection. Although RitTer (1905) reported Doliolum tritonis, Doliolum ehrenbergii and Doliolum mülleri from the San Diego region, it is hardly possible to determine which of $D$. denticulatum or $D$. nationalis is represented by his $D$. ehrenbergii.

\begin{tabular}{|c|c|c|}
\hline & $\begin{array}{r}\text { off San Diego } \\
\text { (35 samples) } \\
\end{array}$ & $\begin{array}{c}\text { Blue-grean water } \\
\text { (19 samples) }\end{array}$ \\
\hline O. longicauda & 4095 & 63 \\
\hline o. fusiformis & 136 & * \\
\hline o. dioica & 1880 & 8400 \\
\hline O. parva & - & $*$ \\
\hline o. labradoriensis & - & $*$ \\
\hline Frit. abjornseni & 12 & - \\
\hline Frit. pellucida & - & * \\
\hline $\begin{array}{l}\text { Frit. borealis } \\
\text { f. typica }\end{array}$ & 17 & 1500 \\
\hline $\begin{array}{l}\text { Frit. borealis } \\
\text { f. sargassi }\end{array}$ & 28 & - \\
\hline App. sicula & 9 & - \\
\hline$K$. tenuis & - & * \\
\hline
\end{tabular}

Table 3. Abundance of respective species of appendicularians in the coastal waters of southern California.

Numerals indicate values Frequency of occurrence $\times$ Mean percentage, $*$-less than 1 .

Frit. borealis f. typica occurred also at Stations 1 and 3 of the Transpac Expedition, which were situated near the blue-green water; there occurred, at the same time, a few individuals of $O$. cophocerca, a warm oceanic water form.

The outline of the appendicularian fauna of this area is shown clearly by ESSENBERG's works (1922 and 1926) based on daily collections taken from the surface of the water at or near the end of the pier at the Scripps Institution for Biological Research for three years. According to her papers, maximum numbers of appendicularian individuals were to be found in the winter season, from October to March or April; minimum numbers in summer. "In general the data shows a very marked correlation between the temperature of the water 
and the number of appendicularians, in which increase of temperature is accompanied by or followed by decrease in numbers and vice versa". $O$. dioica and $O$. longicauda were the commonest species, they occurred even throughout summer and rarely in large numbers in this warm season. Other forms occurred mostly in winter and unevenly in the season, unusually dense populations of $O$. fusiformis and Frit. formica were recorded. In all, she listed forty-eight species, of which thirty were new species. I believe, however, this number is too large for this region. In my opinion, her list is reducible to the following twenty-one forms, all her new species being treated as synonyms of already known species.
1. O. longicauda
2. O. fusiformis
3. O. graciloides ( $=$ O. californica ESSENBERG)
4. O. dioica
5. O. rufescens
6. O. cophocerca
7. O. labradoriensis

It is very possible that $O$. albicans described by EsSENBERg may be identical with $O$. labradoriensis, because the shape of its left stomach lobe and the arrangement of the subchordal cells resemble those of labradoriensis rather than those of albicans.

8. Oikopleura vanhöffeni LoHManN, 1896

9. Steg. magnum

Megalocercus diegensis ESSENBERG may be safely identified as Steg. magnum, as IHLE has already mentioned in his note of 1929.

10. Pelagopleura gracilis LoHMANN, 1914 (=Althoffia pacifica EsSENBERG)

11. Frit. haplostoma

Frit. lucibila and Frit. limpida described by EsSENBERG as new species are evidently identical with the present species. Frit. truncata EsSENBERG might also be treated under this species.

12. Frit. abjornseni

Frit. lohmanni, Frit. amygdala and Frit. tereta described by EsSENBERG as new species are evidently identical with the present species. Frit. campila and Frit. tacita, both described by ESSENBERG as new species, may safely be include in the "haplostoma"-group and identified as haplostoma or abjornseni rather than be treated as distinct species.

13. Frit. formica

14. Frit. pellucida

15. Frit. borealis f. typica (=Frit. borealis by ESSENBERG)

Frit. delicata ESSENBERG has the tail ending in an acute point; the structure of the trunk is, however, related closely to that of Frit. borealis f. typica or Frit. haplostoma. Probably this is a form attributable to Frit. haplostoma having an imperfectly preserved trunk or one belonging to Frit. borealis f. typica having an imperfectly preserved tail which is shrunk near the distal end.

16. Frit. borealis f, intermedia (=Frit. juncea EsSENBERG, ? Frit. gigas EssEN. BERG, Frit. claudaria Essenberg) 
Frit. exilis and Frit. pulchrituda described by ESSENBERG as new species, are considered safely to belong to the species borealis and may be classified as f. intermedia or f. typica. Frit. nitida ESSENBERG and Frit. brevicollis ESSENBERG have the tail ending in a pointed tip, but the structure of their trunks resembles very closely that of Frit. borealis $\mathrm{f}$. typica or f. intermedia. It is very possible that these two are nothing but imperfectly preserved specimens of $\mathrm{f}$. intermedia, in which the posterior end of the tail fin is shrunk as to be seen ending in an acute tip, because the tail-musculature is rather wider for f. typica. Frit. tenebra and Frit. artus, both having the tail ending in an acute tip and identified by ESSENBERG as new species, may safely be identified as Frit. borealis f. intermedia or f. typica, for the same reason as mentioned above.

17. Frit. borealis f. sargassi (=Frit. sargassi and Frit. ritteri by EsSENBERG, Frit. trigonis ESSENBERG)

Frit. diafana, Frit. plana and Frit. clava, all described by EssENBERG as new species, may safely be identified as Frit. borealis f. sargassi having a rather narrow tail musculature. Frit, angularis and Frit. velocita are provided with the tail ending in an acute tip, but the structure of their trunks are just the same as that of Frit. borealis f. sargassi. Very probably these are imperfectly preserved specimens of Frit. borealis f. sargassi in which the tail fin is fairly shrunk.

18. Frit. megachile (=Frit. macrotrachela ESSENBERG and Frit. dispara ESSENBERG)

The complete absence of any glandular appendages on the stomach and intestine is common to Frit. megachile and two ESSENBERG's species. The distal end of the tail fin is widely cut in, the trunk is very elongate and the ovary and testis are arranged antero-posteriorly in all these three forms.
19. Frit. venusta (=Frit. inverta ESSENBERG)
20. App. sicula
21. K. tenuis

Most of Essenberg's new species are considered to be included in the "Formenkreis" of Fritillaria haplostoma or Fritillaria borealis. And these two species are well known by their remarkable variability found in the size of matured individuals, body shape and width of tail musculature. In the group of Frit. haplostoma, one end of the variation is represented by a comparatively large typical form which has a very elongate trunk, the posterior end of the oikoplast epithelium being far apart from the stomach, and a very narrow tail musculature, while the other end of the variation is shown by Frit. arafoera which has a very short trunk and a fairly wide tail musculature; and Frit. abjornseni is considered to be situated near Frit. arafoera (TokiokA $1955 \mathrm{a}$ and $1956 \mathrm{c}$ ). The length of the distal exposed portion of chorda decreases towards Frit. arafoera. I have treated Frit. abjornseni and Frit. arafoera as distinct species. It is, however, very probable that these may be included in the single species represented by Frit. haplostoma and treated as intraspecific varieties or forms, when the biometrical and statistical studies are made on many specimens from various localities. Actually BJörNBERG and ForNERIS (1955) are treating abjornseni as a form of Frit. haplostoma against f. typica of the species.

- The "Formenkreis" of Fritillaria borealis was shown in the earlier stage of 
the study of appendicularian taxonomy by the following four species: Frit. borealis Lohmann 1896 a, Frit. sargassi Lohmann 1896 b, Frit. messanensis LohmanN 1899 and Frit. ritteri AIDA 1907. Later, LOHMANN (1905) united the first two into Frit. borealis and subdivided the species into three formae and one variety; they were

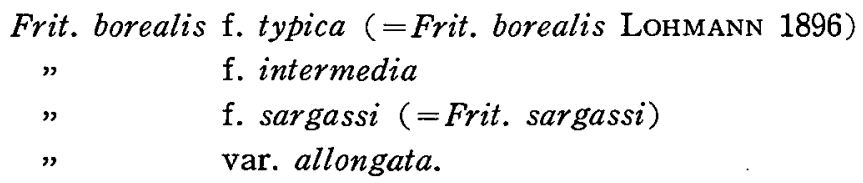

Then he rearranged these forms all as formae of Frit. borealis (1926).

$\begin{array}{ll}\text { Frit. borealis } & \text { f. typica } \\ & \text { f. intermedia } \\ " & \text { f. allongata } \\ " & \text { f. sargassi } \\ " & \text { f. ritteri (=Frit. ritteri AIDA) }\end{array}$

Lastly (1931) he revised the classification as follows:

$\begin{array}{ccc}\text { Frit. borealis acuta typica } \\ " & \text { prolifera } \\ " & \text { truncata intermedia } \\ " & " & \text { allongata } \\ " & " & \text { crassa } \\ " & " & \text { ritteri } \\ " & " & \text { sargassi. }\end{array}$

All these subspecies, varieties or formae were defined by the combination of various shapes and relative positions of the testis and ovary and different width of the tail musculature, the appearance of the distal end of the musculature and the shape of the shoulder-like basal part of the tail fin. However, the characteristics concerning the tail, which were adopted by LOHMANN as clues to separate forms, are completely continuous one another that any distinct boundaries cannot be discerned. The variations found in the shape of the ovary and testis are also quite continuous. Only the relative position of the testis and ovary seems to be very stable, namely the arrangement of the ovary and testis may be symmetrical or asymmetrical. Allongata and prolifera features are nothing but deformations found in the symmetrical arrangement, most possibly found in individuals matured in small sizes; while the crassa feature is merely a modification of the asymmetrical arrangement, found frequently in small-sized mature individuals. And usually the symmetrical arrangement of the gonad is accompanied with the narrower tail musculature and the asymmetrical arrangement of the gonad is combined with the wider tail musculature in which occurs most commonly the truncate feature of the distal end of the musculature. VERNiERES (1933) estab- 
lished a new variety Frit. borealis acuta f. typica var. mediterranea which was resembling Frit. borealis truncata intermedia very closely, but differing from it in having the tail musculature ending in a pointed tip (p. 42, fig. 18). This variety seems, however, to be treated more reasonably as a typica-form side individual of intermedia-form. For these reasons, I shortened the classification of Frit. borealis into only three forms, f. typica with the symmetrical arrangement of the gonad and the very narrow tail musculature, f. sargassi with the asymmetrical arrangement of the gonad and the much wider tail musculature and $\mathrm{f}$. intermedia with the symmetrical arrangement of the gonad and the tail musculature showing an intermediate feature between f. typica and f. sargassi (1940). Here, it is not impossible that f. intermedia might be included in f. typica as a variant mostly occurring in the warm water or in the mixing area between the cold and warm waters. Frit. messanensis has been left outside the discussion about the "Formenkreis" of Frit. borealis as BJÖRNBERG and FORNERIS (1955) treat this as a distinct

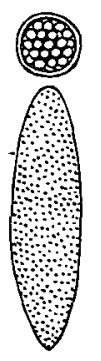

1

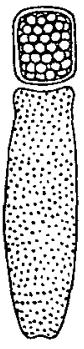

2

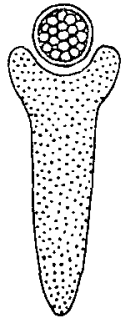

3

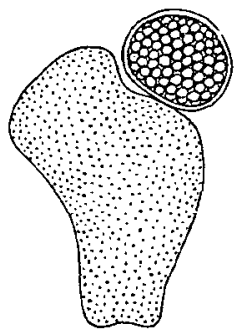

4

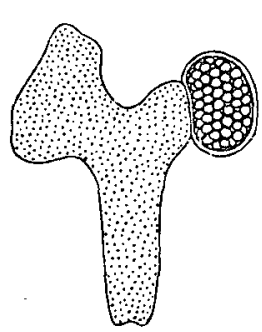

5

Fig. 1. Schemata of the arrangement of ovary and testis in various forms of Fritillaria borealis LOHMANN. 1‥ typica and $\mathrm{f}$. intermedia, $2 \cdots \mathrm{f}$. allongata, $3 \cdots \mathrm{f}$. prolifera, $4 \cdots \mathrm{f}$. crassa, $5 \cdots$ f. sargassi and f. ritteri.

species. But, I feel, in all probability, that this might be a small form of $f$. intermedia with unusually wider tail musculature.

It is very difficult to show exactly what the cause of such morphological variations found in Frit. haplostoma and Frit. borealis is. Even the variation found in the body size does not seem to be simply explained. However, it is very probable that the variable environment might be favourable to the occurrence of those variants mentioned above. The area covering the pier at the Scripps Institution where EsSENBERG collected her samples is effected by the southward flowing California Current and the northward flowing narrow Davidson Current bordering the coast, and these two currents change their strength from time to time, besides some upwelled water masses may join there at times and make the environment of the area very complicated. Thus, it is very resonable that EsSENBERG found so many variants in specimens of Frit. haplostoma and 
Frit. borealis collected from this area of complicated environment and named them respectively as distinct species. But, the features characterizing these new species should be treated as the intraspecific variations found in these two species. Among the species listed by EsSENBERG, the occurrence of $O$. vanhoffeni, the species characteristic of the very cold arctic water, must be especially noted.

In the more northern part of the blue-green water, BIGELow and LESLIE (1930) records the common occurrence of O. labradoriensis in July, 1928 in Monterey Bay, the sufficiently abundant catch of $O$. dioica and the questionable occurrence of $O$. intermedia. O. vanhöffeni was, however, not found there.

\section{APPENDICULARIANS IN LAGOONS OF BAJA CALIFORNIA}

(Table 4)

Considerable numbers of Oikopleura dioica were found in four of ten plankton samples collected in Scammon's lagoon situated approximately at $27^{\circ} 45^{\prime} \mathrm{N} \times$ $114^{\circ} 10^{\prime} \mathrm{W}$, Oct. 9-12, 1955. The water at Stations 10 and 16 was characterized by dominancy of a copepod Paracalanus, that of Station $15 \mathrm{~B}$ was predominated by Acartia, while the sample from Station 15 A contained Paracalanus, Oithona and Acartia.

\begin{tabular}{|l|c|c|c|}
\hline Stations & Salinity & O. dioica & O. longicauda \\
\hline St. 10 & $36.3 \%$ & 13 & - \\
\hline St. $15 \mathrm{~A}$ & $34.7 \%$ & 134 & 1 \\
\hline St. 15B & & 226 & - \\
\hline St. 16 & $37.6 \%$ & 10 & - \\
\hline
\end{tabular}

Table 4. Occurrence of appendicularians in Scammon's lagoon.

Besides, I had a chance to examine two samples towed respectively at 2 and 3 feet deep for five minutes near North End of Manuela lagoon, situated in a short distance north to Scammon's lagoon, on Oct. 12, 1952. These samples seemed to consist nearly of the pure Acartia population and I could not find any appendicularians in them. For positions of sampling stations, see Fig. 24 in my paper of 1959.

\section{PELAGIC TUNICATES IN THE SHELLBACK AREA}

(App. Tables 4-5, Tables 5-6 and Text-figs. 2-3)

Thirty-six species were found in the collection of the Shellback Expedition. Fritillarians were rather scarce in the collection, this is probably due to the fact that the samples were towed by a large net. O. longicauda was the commonest species and followed by $O$. cophocerca, $O$. rufescens and $O$. fusiformis. O. albicans 
occurred also in a little abundance. The ratio $F / L$ is very low, mostly less than 0.10 ; but the real value might be much higher, because the damaged specimens of oikopleurids were very abundant in this collection and these might include a significant number of $O$. fusiformis. The distribution of $\mathrm{F} / \mathrm{L}$ in the Shellback

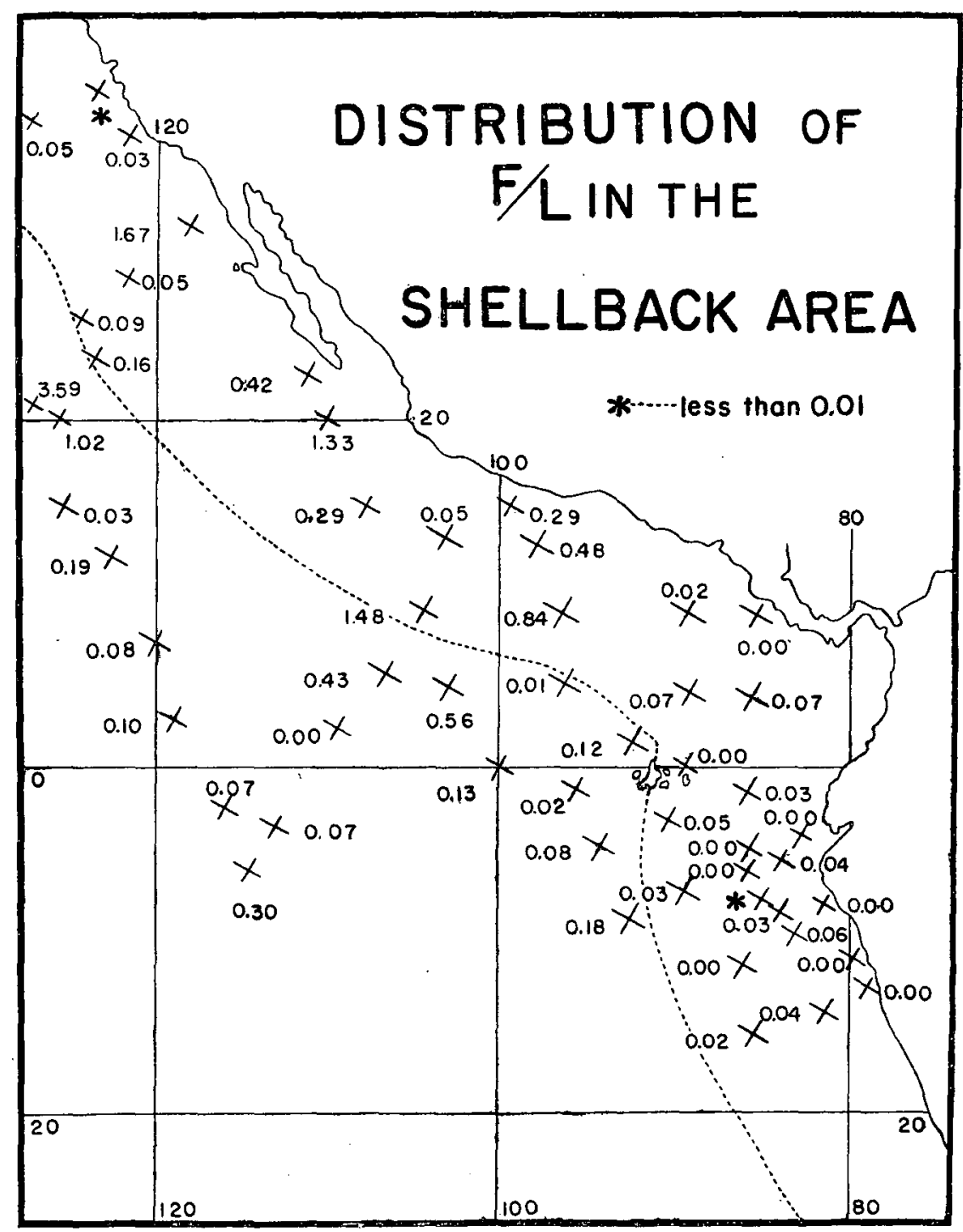

Fig. 2. Distribution of $\mathrm{F} / \mathrm{L}$ in the Shellback area.

area is shown in Fig. 2. The value seems to trend towards the slight decrease near the coast; this may be seen rather easily in Table 6 , in which stations are divided into the inshore and offshore groups by drawing a line about 600 miles 
apart from and running parallel to the coast line and values at stations in respective groups are arranged so as to make the comparison easier. The abovementioned 600 mile line is shown by a broken line in Fig. 2. Of fritillarians, only Frit. pellucida and Frit. borealis f. sargassi occurred in significant numbers, Frit. formica f. digitata and Frit. haplostoma were as scarce as Frit. tenella and Frit. venusta.

Of doliolums, Doliolum denticulatum occurred most frequently and abundantly. Doliolum nationalis and Doliolina intermedia occurred commonly, too, but much

\begin{tabular}{|c|c|c|}
\hline $\begin{array}{c}\text { Number of } \\
\text { sampling stations }\end{array}$ & \multicolumn{2}{|c|}{48} \\
\hline 0 & 10 & \\
$*-0.10$ & 21 & \multirow{2}{*}{44} \\
\hline $0.11-0.50$ & 11 & \\
\hline $0.51-1.00$ & 2 & \\
\hline $1.01-2.00$ & 4 & 4 \\
\hline
\end{tabular}

Table 5. Occurrence of respective values of $F / L$ in the Shellback area.

\begin{tabular}{|c|c|c|c|c|}
\hline & & $\begin{array}{l}\text { Inshore } \\
\text { stations }\end{array}$ & & $\begin{array}{l}\text { Offshore } \\
\text { stations }\end{array}$ \\
\hline $\begin{array}{l}\text { Number of } \\
\text { stations }\end{array}$ & & 36 & & 18 \\
\hline 0 & 10 & \multirow{2}{*}{$75 \%$} & 1 & \multirow{2}{*}{$50 \%$} \\
\hline$*-0.10$ & 17 & & 8 & \\
\hline $0.11-0.50$ & 5 & \multirow{2}{*}{$17 \%$} & 6 & \multirow{2}{*}{$39 \%$} \\
\hline $0.51-1.00$ & 1 & & 1 & \\
\hline $1.01-2.00$ & 3 & \multirow{2}{*}{$8 \%$} & 1 & \multirow{2}{*}{$11 \%$} \\
\hline$>2.01$ & - & & 1 & \\
\hline
\end{tabular}

Table 6. Occurrence of respective values of $\mathrm{F} / \mathrm{L}$ in the inshore and offshore waters in the Shellback area and adjacent region.

less frequently and less abundantly than $D$. denticulatum. The dense population of Doliolum nationalis was found at SB 137 and a pretty dense one at SB 115. Dolioletta gegenbauri var. tritonis occurred at some stations in significant numbers, most abundantly at SB 118 and then at SB 122 and SB 137. The distribution of $D$. nationalis seems to trend towards the increase in the inshore water in this area. D. gegenbauri var. tritonis also occurred more frequently in the inshore water than in the offshore water and consequently was often collected together with $D$, nationalis (occurrence together with $D$. nationalis 10 : occurrence inde- 
pendent of $D$. nationalis 4). The collection of the "Vettor Pisani" contained Doliolum nationalis, Dolioletta gegenbauri var. tritonis and Doliolina krohni from the waters along the Chilean coast, Doliolum denticulatum and Doliolina krohni from

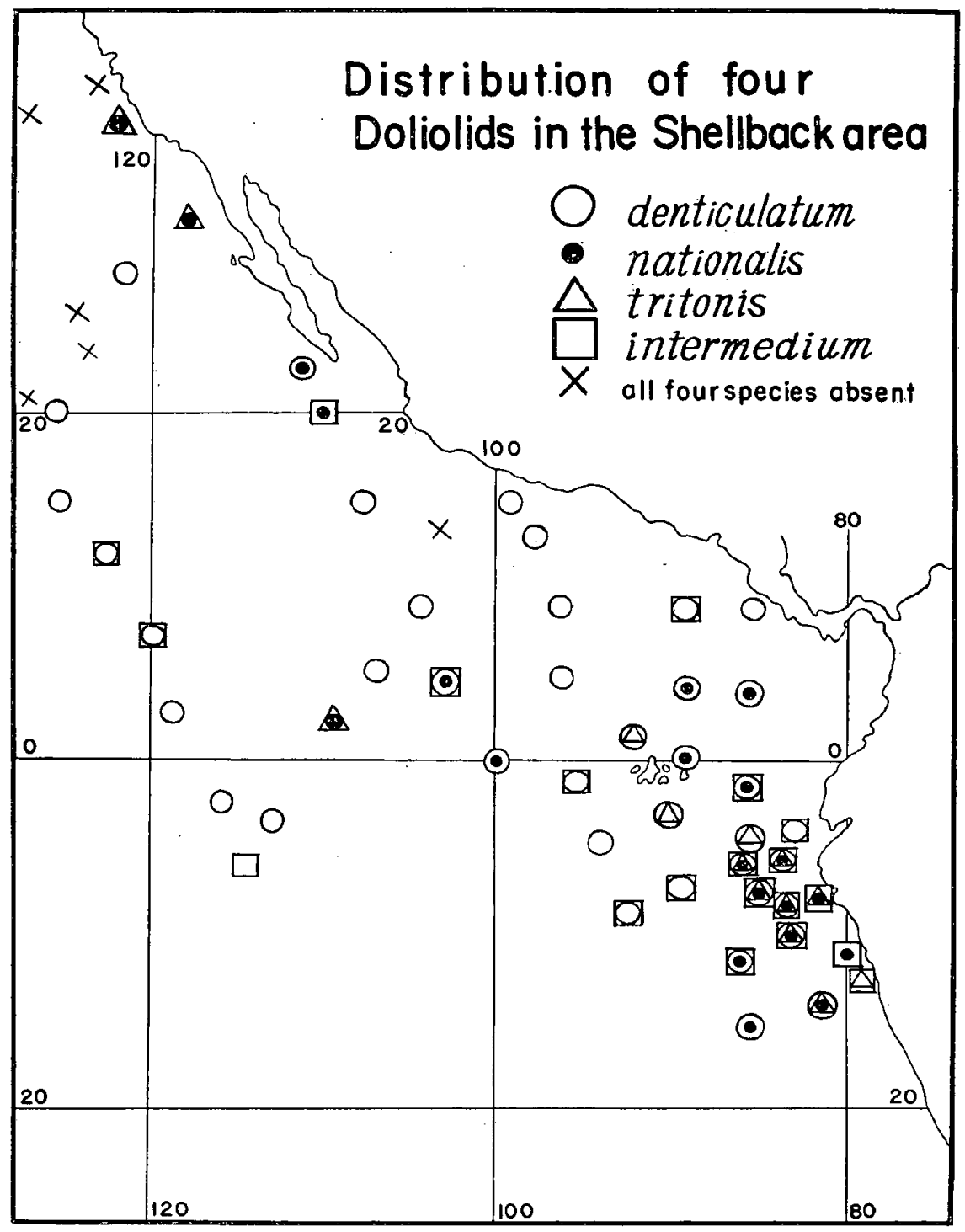

Fig. 3. Distribution of four doliolids in the Shellback area.

the waters around the Galapagos Islands and Doliolum denticulatum, Doliolum nationalis and Dolioletta gegenbauri var. tritonis from the Gulf of Panama (BORGERT 1896). This seems to show the frequent occurrences of Doliolum nationalis and 
Dolioletta gegenbauri var. tritonis in the inshore waters. Thalia democratica was the most abundant of all salpas and followed by Salpa cylindrica and Iasis zonaria. Of the solitary form of the first species, var. orientalis occurred slightly more frequently than typical forms, although individuals were fewer in the former than in the latter.

\section{PELAGIC TUNICATES OF THE TRANSPAC EXPEDITION}

(App. Tables 6-7, Table 7 and Text-figs. 4-5)

Putting two subarctic species, $O$. labradoriensis and Frit. borealis f. typica, aside, $O$. longicauda was the commonest species and next $O$. fusiformis. Frit. borealis $\mathrm{f}$. sargassi and $O$. rufescens were also pretty common, then $O$. dioica; $O$. cophocerca, Frit. pellucida, Steg. magnum, O. graciloides and O. albicans occurred in significant numbers, but much less than preceding species. The scarcity of $M$. huxleyi and the absence of Frit. tenella and Frit. venusta in this collection are

\begin{tabular}{|c|c|c|c|c|c|c|c|c|c|c|}
\hline Sections & \multicolumn{2}{|c|}{ NW } & \multicolumn{2}{|c|}{ NWM } & \multicolumn{2}{|c|}{$\mathrm{NM}$} & \multicolumn{2}{|c|}{ NEM } & \multicolumn{2}{|c|}{$\mathrm{NE}$} \\
\hline $\begin{array}{c}\text { Number of } \\
\text { samples }\end{array}$ & \multicolumn{2}{|c|}{24} & \multicolumn{2}{|c|}{14} & \multicolumn{2}{|c|}{13} & \multicolumn{2}{|c|}{4} & \multicolumn{2}{|c|}{7} \\
\hline $0 / 0$ & \multicolumn{2}{|c|}{-} & \multicolumn{2}{|c|}{-} & \multicolumn{2}{|c|}{-} & \multicolumn{2}{|c|}{-} & \multicolumn{2}{|c|}{ - } \\
\hline 0.00 & 1 & \multirow{4}{*}{20} & - & \multirow{4}{*}{8} & - & \multirow{4}{*}{3} & - & \multirow{4}{*}{1} & 1 & \multirow{4}{*}{3} \\
\hline$<0.10$ & 2 & & - & & - & & - & & 1 & \\
\hline $0.11-0.50$ & 13 & & 6 & & 1 & & - & & 1 & \\
\hline $0.51-1.00$ & 4 & & 2 & & 2 & & 1 & & - & \\
\hline $1.01-2.00$ & 4 & \multirow{5}{*}{4} & 1 & \multirow{5}{*}{6} & 3 & \multirow{5}{*}{10} & - & \multirow{5}{*}{3} & 1 & \multirow{5}{*}{4} \\
\hline $2.01-5.00$ & - & & 1 & & 3 & & 1 & & 1 & \\
\hline $5.01-10.00$ & - & & - & & 1 & & - & & - & \\
\hline$>10.01$ & - & & 1 & & - & & - & & 1 & \\
\hline$\infty$ & - & & 3 & & 3 & & 2 & & 1 & \\
\hline
\end{tabular}

Table 7. Occurrence of respective values of $F / L$ in sections of the North Pacific surveyed by the Transpac Expedition and other expeditions. For the position of respective sections see Figs. 4 and 5 .

probably due to the fact that most stations were situated in the area of higher latitudes more northern than the subtropical zone.

The distribution of $\mathrm{F} / \mathrm{L}$ seems to show the trend towards the increase in the central part of the North Pacific. This does not mean the increase of $O$. fusiformis individuals in the central part of the North Pacific. Rather, the absolute abundance of $O$. fusiformis may be larger in the areas not far from the coast. Then this can be accepted as to mean the rapid drop of $O$. longicauda population 


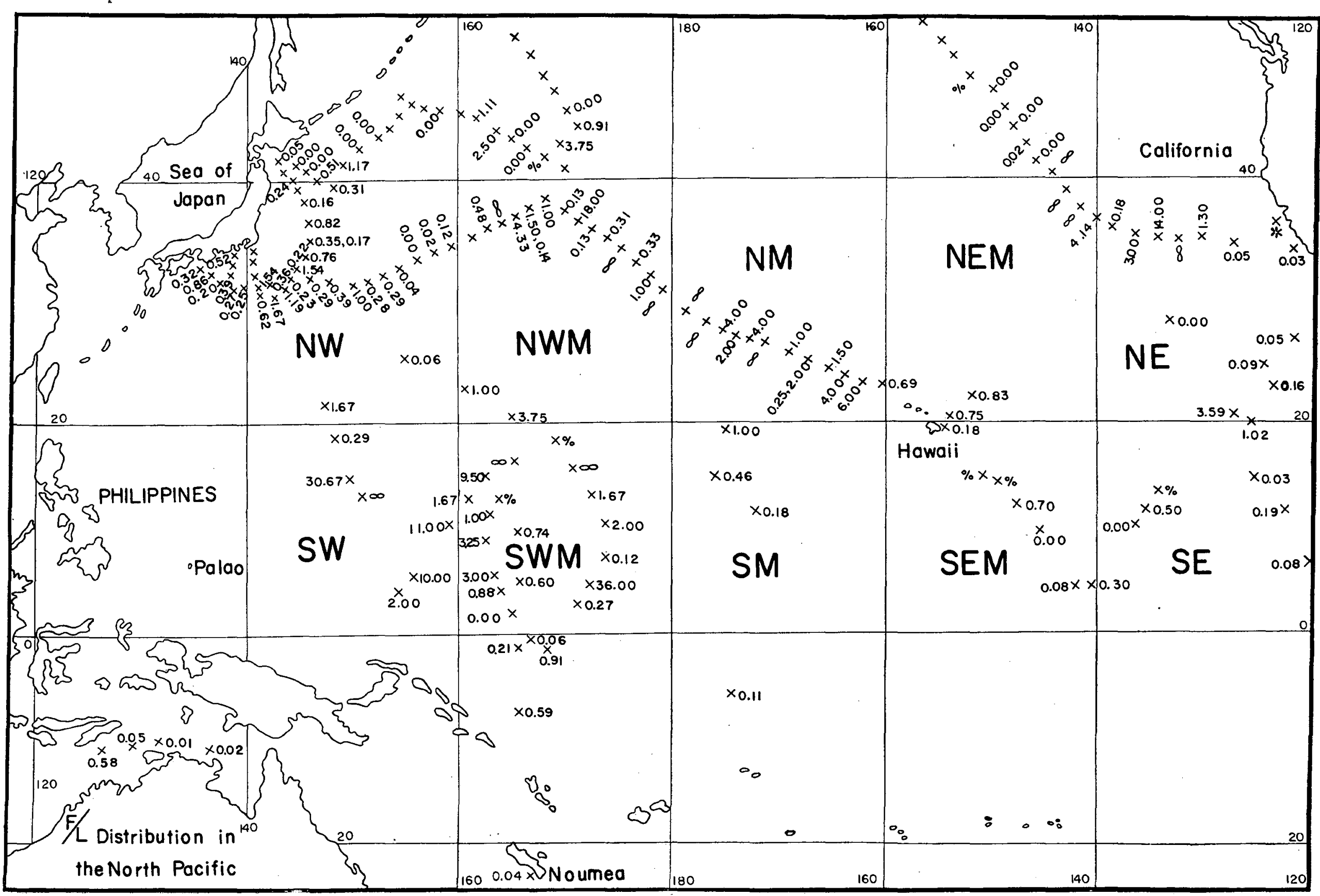

Fig. 4. Distribution of $\mathrm{F} / \mathrm{L}$ in the North Pacific. 


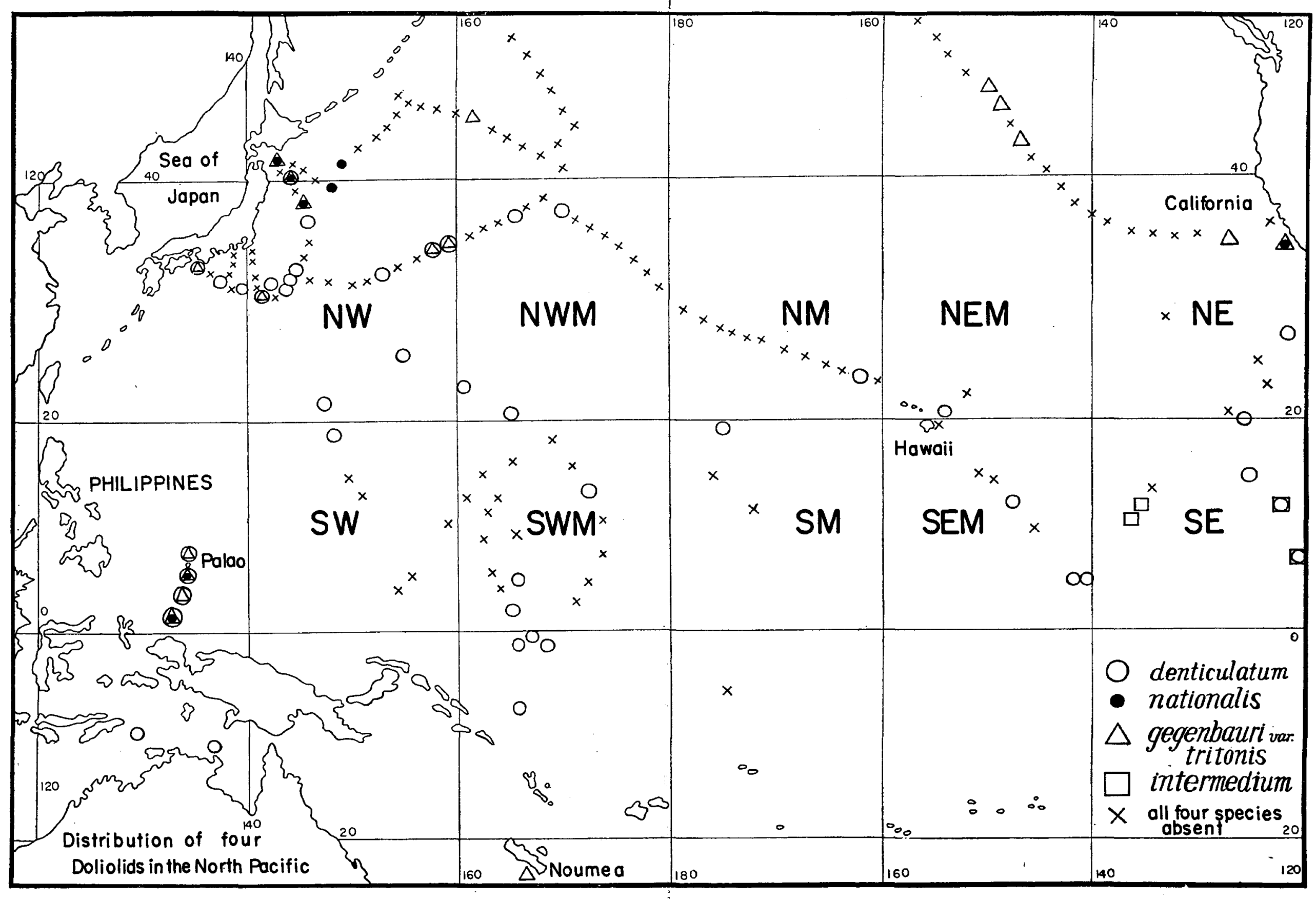

Fig. 5. Distribution of four doliolids in the North Pacific. 
in the central North Pacific. The area where O. longicauda greatly predominated over $O$. fusiformis was much wider in the western Pacific than in the eastern Pacific.

Thalia democratica was the commonest of all thaliaceans as in other collections. There were 10 samples in which the solitary form of this salp was found, the typical form occurred in five of them and the variety orientalis did in seven. Doliolum denticulatum was distributed very widely and occurred frequently (Fig. 5), while the distribution of $D$. nationalis was confined to the area near the coast, although sometimes it occurred in very dense populations as seen in samples from Stations 74, 76 and 78. Dolioletta gegenbauri var. tritonis occurred also rather commonly, but its distribution did not seem to be extended to the central part of the North Pacific. The frequent occurrence of this doliolid seemed to be confined to the area near the coast where O. longicauda was maintaining its dominancy or to the area along the mixing region between the subarctic water and the warm water.

\section{PELAGIC TUNICATES OF THE MIDPAC EXPEDITION}

(App. Tables 8-9)

Twenty-six species of appendicularians occurred in the collection. The most abundant one was $O$. longicauda which was then followed by $O$. rufescens, $O$. cophocerca and $O$. fusiformis. $M$. huxleyi and Steg. magnum were also found commonly. Of fritillarians, Frit. borealis f. sargassi was the commonest, and Frit. pellucida and Frit. formica f. digitata followed it. Frit. haplostoma was rather scarce in this collection, its value Frequency of Occurrence $\times$ Mean Percentage was smaller even than that of Frit. tenella. The values of F/L seemed to be lowered towards the south in the section SM and they were very small near the coast in the section NE (see Fig. 4); the values in sections SEM and SE were not large, either.

Thalia democratica was the commonest salpa; of solitary forms, var. orientalis was met with much more frequently than the typical form was (solitary forms of the typical form occurred in 6 samples, solitary forms of var. orientalis in 17 samples, both forms occurred in 4 samples). Doliolum denticulatum was rather common, while $D$. nationalis was quite absent in the present collection. Doliolina intermedia occurred in significant numbers at only Stations 7 and 8.

\section{PELAGIC TUNICATES OF THE EQUAPAC EXPEDITION}

(App. Tables 10 and 11)

Twenty-six species of appendicularians were found in five samples of the Equapac Expedition. O. longicauda and Frit. pellucida were the most prominent species in this collection and followed by $O$. fusiformis, O. rufescens and Frit. tenella. Frit. borealis f. sargassi occurred also in significant numbers. O. cophocerca, 
M. huxleyi, Steg. magnum and Frit. venusta were pretty common, though much less than preceding species. $F / L$ varied in the range from 0.11 to 0.74 , being 0.45 on an average. Thalia democratica was the commonest thaliacean, solitary forms of both the typical form and var. orientalis occurred at the similar frequency and in very similar numbers. Doliolum denticulatum occurred rather commonly, but none of $D$. nationalis.

\section{PELAGIC TUNICATES COLLECTED BY THE SYUNKOTU-MARU IN MAY-JUNE 1954}

\section{(Appendix Table 12, Tables $8-9$, see also Table 1 )}

The area surveyed by the Syunkotu-maru covers most parts of the Marshall Islands and is shown in my previous paper* dealing with chaetognaths of the area. The results of the examination on appendicularians collected during the cruise have already been published in my paper of $1955 \mathrm{~d}$. Important oikopleurids were $O$. fusiformis, $O$. longicauda, $M$. huxleyi, Steg. magnum and $O$. rufescens;

\begin{tabular}{|l|c|c|c|}
\cline { 2 - 4 } \multicolumn{1}{c|}{} & $\begin{array}{c}\text { North Equatorial } \\
\text { Current }\end{array}$ & $\begin{array}{c}\text { Counter Equatorial } \\
\text { Current }\end{array}$ & $\begin{array}{c}\text { South Equatorial } \\
\text { Current }\end{array}$ \\
\hline Number of samples & 17 & 7 & 4 \\
\hline O. longicauda & 71 & 100 & 100 \\
\hline O. fusiformis & 88 & 100 & 75 \\
\hline O. rufescens & 47 & 71 & 100 \\
\hline O. cophocerca & 12 & - & 75 \\
\hline M. huxleyi & 82 & 86 & 100 \\
\hline \begin{tabular}{l} 
Steg. magnum \\
\hline Frit. haplostoma
\end{tabular} & 24 & 100 & - \\
\hline Frit. formica & - & 43 & - \\
\hline Frit. pellucida & 47 & 24 & - \\
\hline $\begin{array}{l}\text { Frit. borealis } \\
\text { f. sargassi }\end{array}$ & 35 & 43 & 25 \\
\hline
\end{tabular}

Table 8. Frequency of occurrence of important species in respective currents remarkable in the area surveyed by the Syunkotu-maru.

while fritillarians were represented mainly by Frit. pellucida, Frit. formica and Frit. borealis f. sargassi. The largest total of appendicularian individuals per each haul was found in samples from the South Equatorial Current. The ratio $\mathrm{F} / \mathrm{L}$ seemed higher in the northern part than in the southern part of the surveyed area (Table 9).

Of 13 distinctly identified species of salps, Thalia democratica, Salpa cylindrica and Cyclosalba pinnata were prominent ones and followed by Salpa fusiformis

* Tokioka, T. (1955): On some plankton animals collected by the Syunkotu-maru in May-June, 1954. I. Chaetognatha. Publ. Seto Mar. Biol. Lab., IV (2-3), pp. 223-225. 
which was fairly fewer than the above-mentioned three species. The solitary form of the typical Thalia democratica occurred at the frequency of $25 \%$, while that of var. orientalis was met with at the frequency of $50 \%$; three of the eighteen occurrences of the solitary form of this salpa were represented by both of the typical form and var. orientalis. Doliolum denticulatum occurred at the frequency of $32 \%$, while none of $D$. nationalis was found in the collection.

\begin{tabular}{|c|c|c|c|c|c|c|}
\hline & \multicolumn{2}{|c|}{$\begin{array}{c}\text { North Equatorial } \\
\text { Currett } \\
\end{array}$} & \multicolumn{2}{|c|}{$\begin{array}{c}\text { Counter Equatorial } \\
\text { Current }\end{array}$} & \multicolumn{2}{|c|}{$\begin{array}{c}\text { South Equatorial } \\
\text { Current }\end{array}$} \\
\hline $\begin{array}{c}\text { Number of } \\
\text { samples }\end{array}$ & \multicolumn{2}{|c|}{17} & \multicolumn{2}{|c|}{7} & \multicolumn{2}{|c|}{4} \\
\hline $0 / 0$ & \multicolumn{2}{|c|}{2} & \multicolumn{2}{|c|}{-} & \multicolumn{2}{|c|}{ - } \\
\hline 0.00 & - & \multirow{4}{*}{5} & - & \multirow{4}{*}{2} & 1 & \multirow{4}{*}{4} \\
\hline$<0.10$ & 1 & & - & & 1 & \\
\hline $0.11-0.50$ & 2 & & 1 & & 1 & \\
\hline $0.51-1.00$ & 2 & & 1 & & 1 & \\
\hline $1.01-2.00$ & 3 & \multirow{5}{*}{10} & 1 & \multirow{5}{*}{5} & - & \multirow{5}{*}{0} \\
\hline $2.01-5.00$ & 1 & & 2 & & - & \\
\hline $5.01-10.00$ & 1 & & 1 & & - & \\
\hline$>10.01$ & 2 & & 1 & & - & \\
\hline$\infty$ & 3 & & - & & - & \\
\hline
\end{tabular}

Table 9. Occurrence of respective values of $\mathrm{F} / \mathrm{L}$ in different currents in the area surveyed by the Syunkotu-maru.

\section{PELAGIC TUNICATES OCCURRING IN THE SURROUNDING WATERS OF THE PALAO ISLANDS}

(App. Tables 15-17, Tables 10-11, Text-figs. 6-8)

While I was staying at the former Palao Tropical Biological Station located on Korôru Island of the Palao Islands during the period from May 1940 to January 1941, I had a chance to examine 62 plankton samples mostly collected at various parts of Iwayama Bay (Fig. 8) which was called a lagoon in the lagoon of the Palao Islands and some other stations in the lagoon. Besides, I examined two series of plankton samples collected by the former Japanese fishery experiment station at Palao with KiTAHARA's quantitative net from $50 \mathrm{~m}$ to the surface. One consisted of 104 samples collected in the neighbouring waters of the islands in the years 1939-40, while the other included 45 samples collected during the Palo-New Guinea cruises 1939-40. The data about fifty of the former and thirtyone of the latter were recorded in a form to be available for the present studies. All available data concerning the pelagic tunicates are given here in App. Tables 15-17. 


\begin{tabular}{|c|c|c|c|c|}
\hline & $\begin{array}{c}\text { North } \\
\text { Equatorial } \\
\text { Current }\end{array}$ & $\begin{array}{c}\text { Counter } \\
\text { Equatorial } \\
\text { Current }\end{array}$ & $\begin{array}{c}\text { South } \\
\text { Equatorial } \\
\text { Current }\end{array}$ & $\begin{array}{c}\text { Lagoon } \\
\text { water }\end{array}$ \\
\hline Number of samples & 46 & 19 & 16 & 62 \\
\hline O. longicauda & 61 & 100 & 94 & 97 \\
\hline o. intermedia & - & 21 & - & - \\
\hline o. fusiformis & 76 & 74 & 94 & 2 \\
\hline $\begin{array}{l}\text { O. fusiformis } \\
\text { f. cornutogastra }\end{array}$ & 28 & 26 & 19 & 87 \\
\hline o. graciloides & 4 & 5 & - & - \\
\hline O. dioica & 7 & 21 & 38 & 81 \\
\hline o. rufescens & 85 & 89 & 100 & 58 \\
\hline O. cophocerca & 52 & 63 & 75 & 2 \\
\hline M. huxleyi & 39 & 63 & 50 & - \\
\hline Steg. magnum & 72 & 79 & 88 & 3 \\
\hline P. verticalis & 9 & 26 & - & - \\
\hline Frit. haplostoma & 65 & 58 & 69 & 60 \\
\hline Frit. abiornseni & 13 & 16 & 13 & 5 \\
\hline Frit. aberrans & 4 & 5 & 一 & - \\
\hline $\begin{array}{l}\text { Frit. formica } \\
\text { f. digitata }\end{array}$ & 65 & 74 & 94 & 2 \\
\hline Frit. gracilis & 9 & - & - & - \\
\hline Frit. fraudax & - & 11 & - & - \\
\hline Frit. pellucida & 65 & 47 & 56 & 6 \\
\hline $\begin{array}{l}\text { Frit. borealis } \\
\text { f. intermedia }\end{array}$ & 2 & 一 & - & - \\
\hline $\begin{array}{l}\text { Frit. borealis } \\
\text { f. sargassi }\end{array}$ & 91 & 79 & 94 & 32 \\
\hline Frit. megachile. & - & - & 6 & - \\
\hline Frit. tenella & - & 5 & - & - \\
\hline Frit. venusta & - & 5 & - & - \\
\hline$T$. fertilis & 4 & 11 & - & - \\
\hline App. sicula & 7 & 26 & 50 & 66 \\
\hline$K$. tenuis & - & 11 & - & - \\
\hline Number of species & 20 & 23 & 15 & 13 \\
\hline
\end{tabular}

Table 10. Frequency of occurrence of respective species in different currents and the lagoon water, at and near the Palao Islands. 


\begin{tabular}{|l|c|c|c|c|}
\cline { 2 - 5 } \multicolumn{1}{c|}{} & $\begin{array}{c}\text { North } \\
\text { Equatorial } \\
\text { Current }\end{array}$ & $\begin{array}{c}\text { Counter } \\
\text { Equatorial } \\
\text { Current }\end{array}$ & $\begin{array}{c}\text { South } \\
\text { Equatorial } \\
\text { Current }\end{array}$ & Total \\
\hline O. longicauda & - & 6 & 7 & 13 \\
\hline O. fusiformis & 2 & - & 2 & 4 \\
\hline O. rufescens & 2 & - & - & 5 \\
\hline O. cophocerca & - & - & - & 0 \\
\hline \begin{tabular}{l} 
M. huxleyi \\
\hline Steg. magnum
\end{tabular} & - & - & - & 1 \\
\hline Frit. haplostoma & 1 & - & - & 1 \\
\hline $\begin{array}{c}\text { Frit. formica } \\
\text { f. } \text { digitata }\end{array}$ & 1 & - & - & 2 \\
\hline Frit. pellucida & - & - & - & 0 \\
\hline $\begin{array}{c}\text { Frit. borealis } \\
\text { f. sargassi }\end{array}$ & - & - & - & 0 \\
\hline
\end{tabular}

Table 11. Abundant occurrences of 10 important species in respective currents in the neighbouring waters of the Palao Islands.

\section{Appendicularians}

Species occurring in the open waters: In all, 26 species occurred in this region (App. Tables 16-17, Table 10). Important forms were O. longicauda, O. fusiformis, O. rufescens, O. cophocerca, M. huxleyi, Steg. magnum, Frit. haplostoma, Frit. formica, Frit. pellucida and Frit. borealis f. sargassi. Among Oikopleura, O. longicauda is the commonest species and followed by $O$. rufescens and $O$. fusiformis. Frit. borealis f. sargassi occurred very frequently, but never in abundance. Relative abundance of $O$. longicauda seemed to be slightly lowered in the North Equatorial Current as seen in Table 11. The increase of O. dioica towards south (Table 10) is considered to show the trend towards the increase of the littoral character in the southern waters.

Species occurring in Iwayama Bay: Thirteen species were found in the collection made in the Bay (Appendix Table 15). Important forms of Oikopleura were $O$. longicauda, $O$. fusiformis f. cornutogastra, $O$. dioica and $O$. rufescens, and significant species of Fritillaria were $F$. haplostoma and $F$. borealis f. sargassi, besides App. sicula. The frequency of abundant occurrence in these species was as follows :

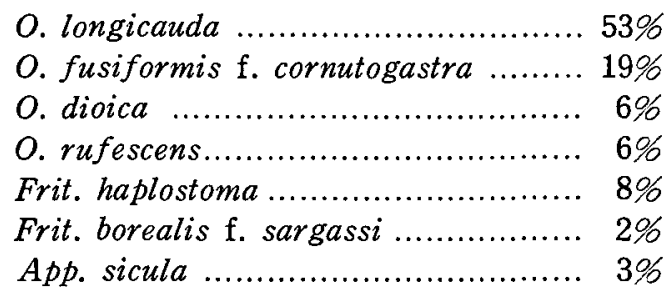




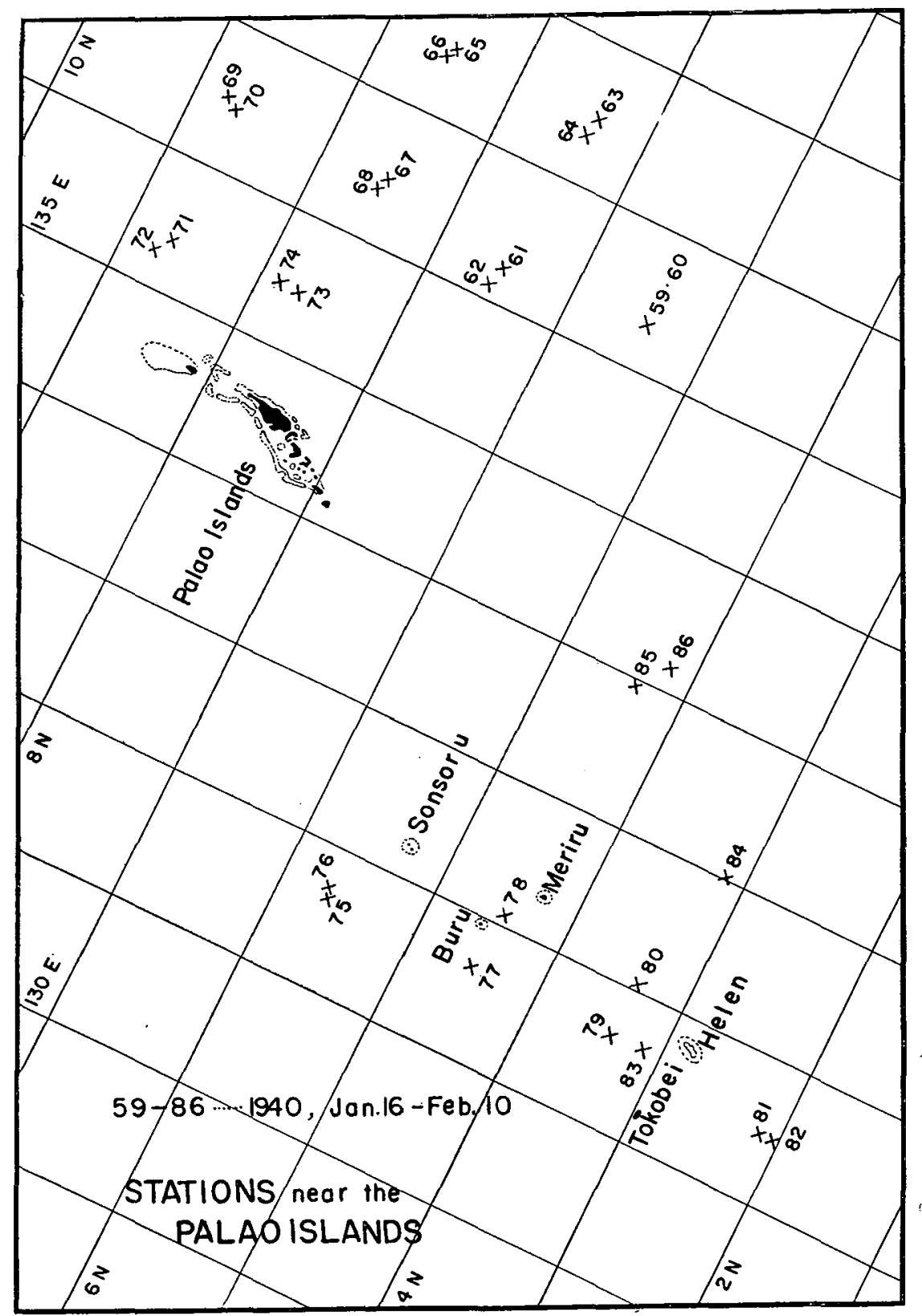

Fig. 6. Sampling stations in the neighbouring waters of the Palao Islands. 


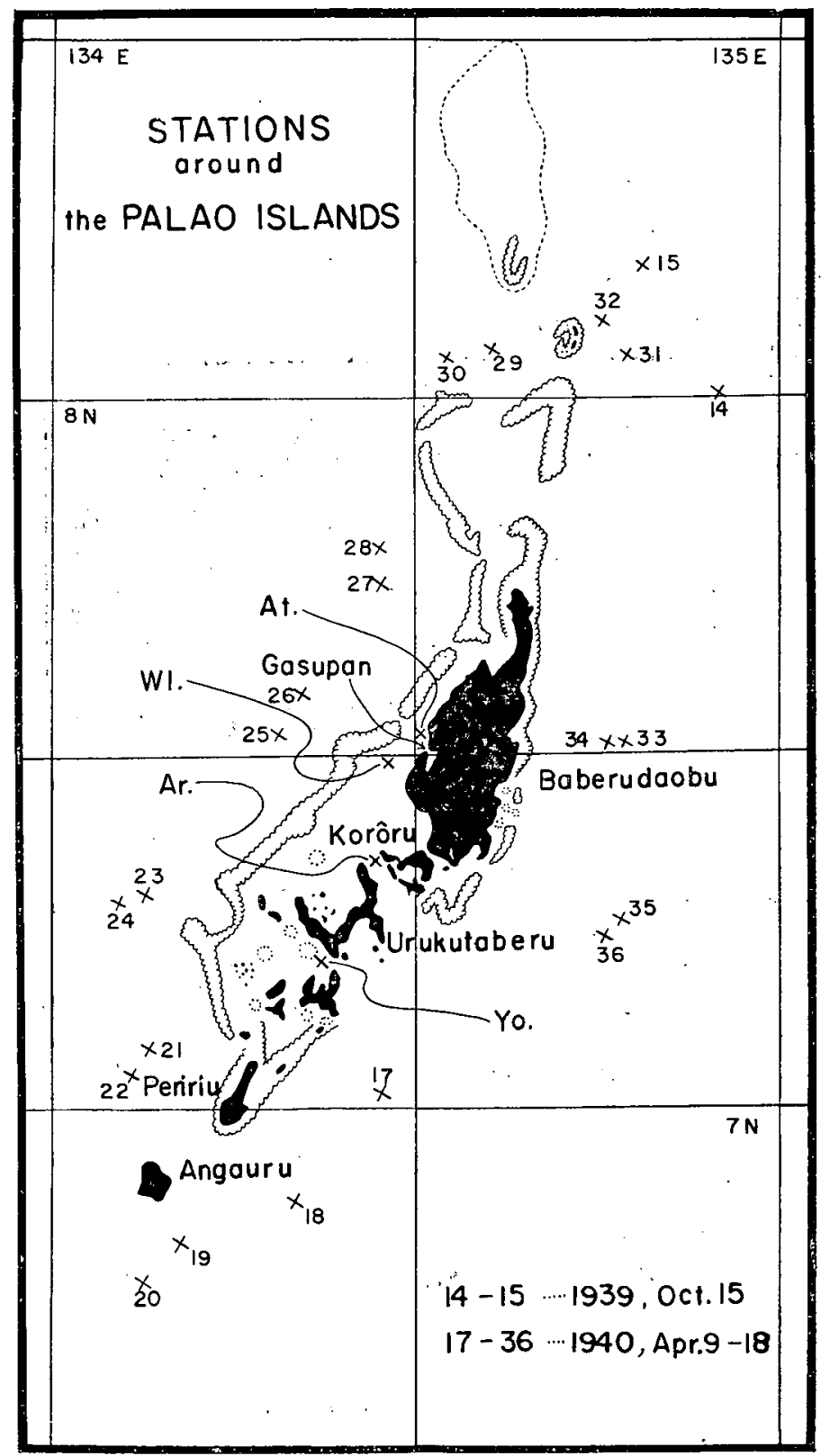

Fig. 7. Sampling stations around the Palao Islands.

Ar....Station off Arakabesan, At...Station off Arumatenguru, Wl...Station in the West Lagoon, Yo....Station in the Yô Channel. 


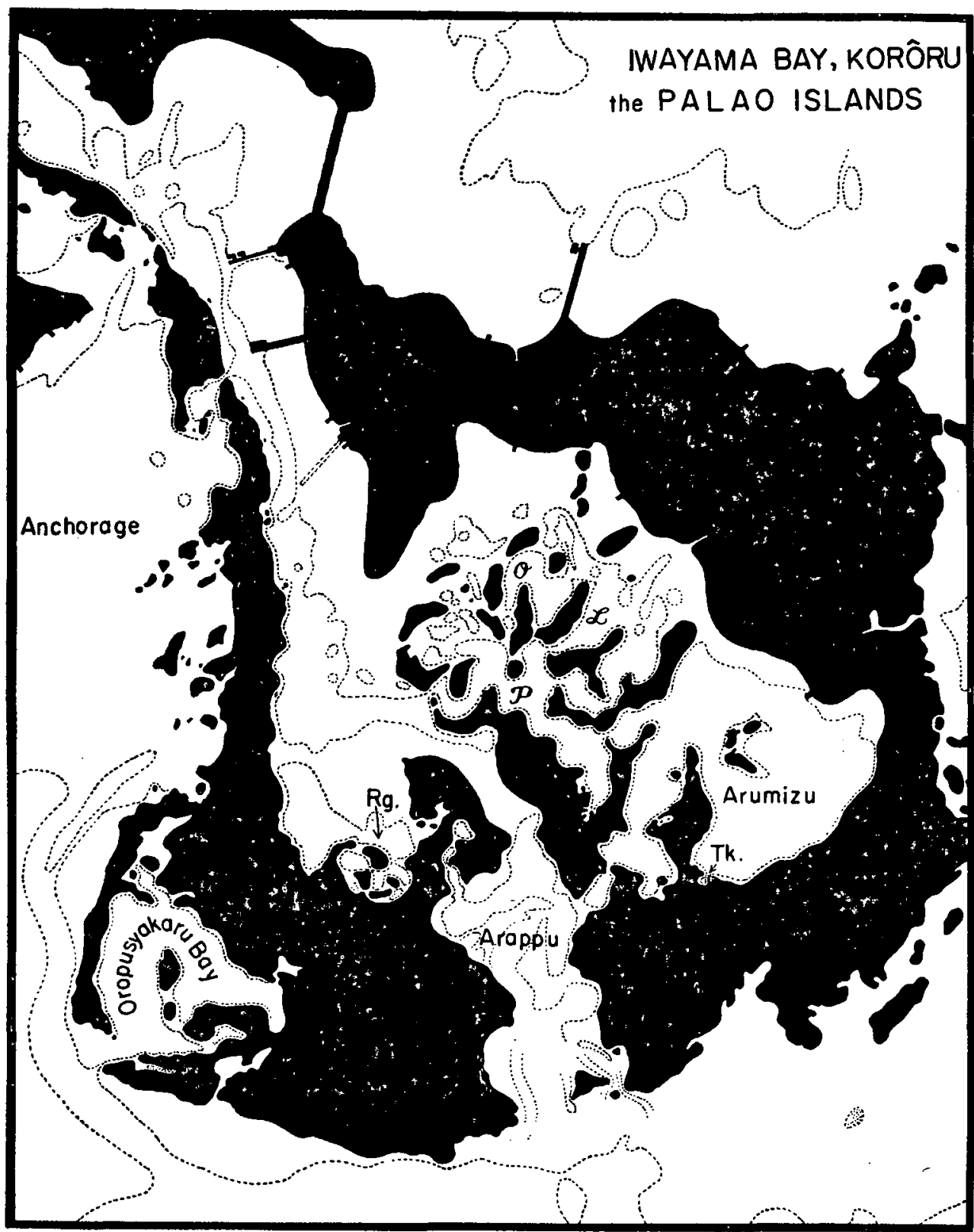

Fig. 8. Iwayama Bay of Korôru Island, the Palao Islands.

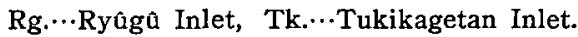


Typical form of $O$. fusiformis, O. cophocerca, Steg. magnum, Frit. formica $\mathrm{f}$. digitata, Frit. pellucida and Frit. abjornseni occurred only insignificantly. Most of these species, excepting the last one, are oceanic water-forms and their frequent occurrence was confined to such areas as Anchorage, Arappu, off Arakabesan and the West Lagoon where the water was strongly affected by the influx of the oceanic water. The exact distribution of Frit. abjornseni is not yet known fully, although the species is regarded by some authors as a neritic form (BJöRNBERG \& FORNERIS 1956 a, TOKIOKA 1956 c).

The distribution of the seven important species in the Bay: O. dioica-This neritic or inlet water-species was distributed nearly evenly in the Bay and found richly even in the inner-most part of the North West Inlet of Oropusyakaru Bay and also in Gasupan Bay where this was the sole appendicularian found there. Seasonal fluctuation of its population was quite insignificant. The density in the West Lagoon was less prominent than in other more protected areas.

O. rufescens, Frit. haplostoma and Frit. borealis f. sargassi-These oceanic waterforms were found in most areas of the Bay, although significant occurrences were not observed in strongly protected portions of the Bay such as divisions $\mathrm{O}, \mathrm{P}$ and Ryûgû Inlet for the first two species and $\mathrm{O}, \mathrm{L}$ and Ryûgû Inlet for the last one.

O. longicauda-Originally this is also an oceanic water-form, although it was found survived in a quite perfect condition in the inner parts of the Bay so that it predominated over any of other appendicularians, even $O$. dioica, in most parts of the Bay. It was distributed nearly evenly in the Bay, but the population seemed to be lowered in some degree in the division $O$ which was considered to be the most protected part of the Bay. Gasupan Bay on the western coast of Palao Island was the only place where this species was not found at all. This species and also other oceanic water-forms appeared in the Bay most abundantly in the latter half of May and in July when the influx of the oceanic water into the Bay was considered to be very prominent.

O. fusiformis f. cornutogastra-This was very abundant in the Bay next the preceding species. It was distributed nearly evenly in the Bay, although it occurred especially numerously off Arakabesan and in the anchorage. Gasupan Bay was the only inlet where this species was not found at all. The population scarcely showed the seasonal fluctuation in the Bay. The frequency of occurrence of thir form in the open waters around the islands seemed to decrease considerably as shown in Table 10. Such features of the distribution and occurrence may possibly be accepted as indicating that the form is a lagoon water-form like Sagitta oceania GRAY, a well known inhabitant of the lagoon water throughout the tropical Pacific islands. Of course, this form can survive in the open sea water and actually it has been reported as being distributed very widely in the warm oceanic water as in the case of $O$. dioica, although there it is found very 
sparsely and less frequently.

App. sicula-This was also distributed very widely and nearly evenly throughout the Bay, although it was generally not so abundant as $O$. longicauda, $O$. fusiformis f. cornutogastra or $O$. dioica. It was found even in the innermost part of the North West Inlet of Oropusyakaru Bay, but it did not occur in Gasupan Bay. There was observed a diatom bloom, consisting chiefly of Lauderia annulata, Rhizosolenia imbricata, Chaetoceros affinis, Chaetoceros Lauderi, Chaetoceros pseudocurvisetus and Biddulphia sinensis, in the area covering $\mathrm{L}, \mathrm{O}$ and $\mathrm{P}$ divisions of the Bay during the period extending from the end of May to the beginning of July. $O$. longicauda and $O$. fusiformis $f$. cornutogastra were very scarce in these parts of the Bay during this diatom propagation. ESSENBERG (1922) mentioned also that the continuing high density of microplankton brought the remarkable decrease of appendicularians in the San Diego region. App. sicula was, however, maintained in these parts as usual even during the diatom bloom; rather its maximal populations throughout the observations made in the Bay were observed in divisions $\mathrm{L}$ and $\mathrm{P}$ during this season. The fact that no repulsion was seen between $A p p$. sicula and the dense diatom population and the peculiarity of the distribution that the frequency of occurrence of this species was higher in the Bay than in the surrounding waters of the islands and in the latter it increased towards the South Equatorial or the New Guinea Coastal Current, where the neritic nature of the water was considerably remarkable, seem to show the possibility that $A p p$. sicula may belong to the neritic form rather than to the pure oceanic species. This species has been reported as being distributed very widely in all tropical waters (Fol 1872, 1874; Langerhans 1880, Lohmann 1896 b, 1909 b, 1931 ; Lohmann \& BüCKMANN 1926, EsSENBERG 1926), but occurring in great abundance near the estuary of the Amazon and off the west coast of Africa in the region of Sierra Leone. According to Bernard (1958), a large number of App. sicula were caught by M. CACHON in September, 1953 in the inner portion of the Bay of Alger. The range of the salinity throughout the recorded localities of this species is relatively wide, $29.80-37.30 \%$. These features seem to support the above-mentioned idea.

Throughout the whole surveyed sections of the Bay and the adjacent areas, appendicularians occurred in all plankton samples but a single one collected off Arumatenguru where the water was heavily polluted by the waste water shed from the aluminium mine. On one hand such oceanic water-forms as O. longicauda and others which were very common in the surrounding waters of the islands penetrated into even the inner-most parts of the Bay and on the other hand a considerable number of an inlet water-form, O. dioica, was maintained in the Bay; besides those, a possible lagoon water-form, $O$. fusiformis $\mathrm{f}$. cornutogastra, and a probable neritic water-form, App. sicula, were distributed evenly in the Bay in fairly prominent densities. The pure inlet water population consisting solely of o. dioica was found only in Gasupan Bay. The abundant occurrence of appen- 
dicularians and the dense diatom vegetation seemed to repulse each other in the Bay, but for App. sicula. However, the dense population of dinoflagellates did not seem to be always repulsive against appendicularians. For instance, in the red water caused by Ceratium furca eugramma and appeared on May 18, 1940 in Ryûgû. Inlet, oikopleurids, especially O. fusiformis f. cornutogastra, were extremely scarce; whereas considerable numbers of them were observed in the dense population of Dinophysis homunculus var. tripos appeared in the end of $M$ ay in the Division of Arumizu.

\section{Thaliaceans}

Three salps occurred in the surveyed area, they were Brooksia rostrata, Salpa cylindrica and Thalia democratica, of which the last one was the commonest. In fifty plankton samples collected in the neighbouring waters of the Palro Islands, Thalia democratica occurred in 14 samples, six of which included the solitary forms. Two of the six occurrences of the solitary form were represented by the typical form, three by var. orientalis and another contained both of the typical form and var. orientalis. No salps occurred in Iwayama Bay. Three species of doliolums were identified in the material. They were Doliolum denticulatum, Doliolum nationalis and Dolioletta gegenbauri var. tritonis. The most important

\begin{tabular}{|ll|}
\hline \multicolumn{3}{|c|}{ Frequency of Occurrence of Doliolum denticulatum } \\
\hline North Equatorial Current (46 samples) & $37 \%$ \\
Counter Equatorial Current (19 samples) & $73 \%$ \\
South Equatorial Current (16 samples) & $81 \%$ \\
\hline
\end{tabular}

species in the open waters was Doliolum denticulatum which occurred also in Iwayama Bay once at the division of Arumizu. Doliolum nationalis was found only in three of 81 samples, two of which were Stations 31 and 32 situated in the North Equatorial Current just near the Palao Islands, while another Station 15 was situated in the New Guinea Coastal Current. This did not occur in Iwayama Bay. Dolioletta gegenbauri var. tritonis was fairly abundant, but much less than Doliolum denticulatum. However, it was found in Iwayama Bay in a very perfect living state as seen in two abundant occurrences in the Division $\mathrm{L}$.

\section{PELAGIC TUNICATES OCCURRING IN THE JAPANESE AND ITS NEIGHBOURING WATERS}

(App. Tables 18-19, Tables $12-21$ and Text-figs. 9-12)

1) Pelagic tunicates in the plankton collection made by a Japanese survey ship in the waters off the north-eastern part of Honsy $\hat{u}$ Island and presented to the Transpac Expedition (Appendix Table 18, Table 12 and Text-figs. 9-10). 
The area where the collection was made is shown as A in Figs. 9-10. The northern part of this area belongs to the mixing region between the cold Oyasio and the warm Kurosio and in two samples form this mixing region there occurred the following forms:

\begin{tabular}{|l|c|c|}
\hline \multicolumn{1}{|c|}{ Stations } & $\mathrm{J} 3$ & $\mathrm{~J} 9$ \\
\hline O. longicauda & 40 & 48 \\
\hline O. fusiformis & - & 1 \\
\hline O. dioica & - & 1 \\
\hline O. labradoriensis & 2 & - \\
\hline Oikopleurid damaged & 1 & - \\
\hline Frit. borealis f. typica & - & 1 \\
\hline
\end{tabular}

Table 12. Appendicularian populations in two samples from the mixing region.

In the warm water-region of this area, occurred eighteen forms, of which $O$. longicauda was the commonest one. O. fusiformis and $O$. rufescens also occurred frequently, but much less abundantly. Frit. borealis f. sargassi was the dominant-most fritillarian and followed by Frit. formica f. digitata. O. cophocerca and Frit. pellucida, both occurring rather abundantly in the tropical waters, were very scarce in the collection. M. huxleyi was not found in the collection. Frit. venusta and Frit. tenella did not occur in any samples, either. F/L was low, less than 1.00 at the maximum, but usually less than 0.48 and 0.18 on an average. In this area, Doliolum nationalis was much commoner than Doliolum denticulatum. Dolioletta gegenbauri var. tritonis occurred at four of 19 stations. Solitary forms of Thalia democratica comprised both the typical and orientalis forms in this collection.

2) Pelagic tunicates in the plankton collection made by the Sôyô-maru in the years 1934 and 1937-39 (Appendix Table 19, Text-figs. 9-10).

The samples of this collection were not examined completely, only a small part was taken out of each sample for examination. Consequently the results of the examination shown in App. Tables 19 1-2 and Figs. 9-10 are considered as only contributing to make a rough outline of distributions of identified species and the value F/L. Lower F/L along the coasts of Japan and the continent, comparatively abundant occurrence of $O$. rufescens and $M$. huxleyi in the southern waters and the wide distribution of Doliolum denticulatum in the oceanic waters against those of Doliolum nationalis and Dolioletta gegenbauri var. tritonis, rather confined to the coastal waters, may be accepted as trends discerned on these data. The commonest salpa was Thalia democratica. 


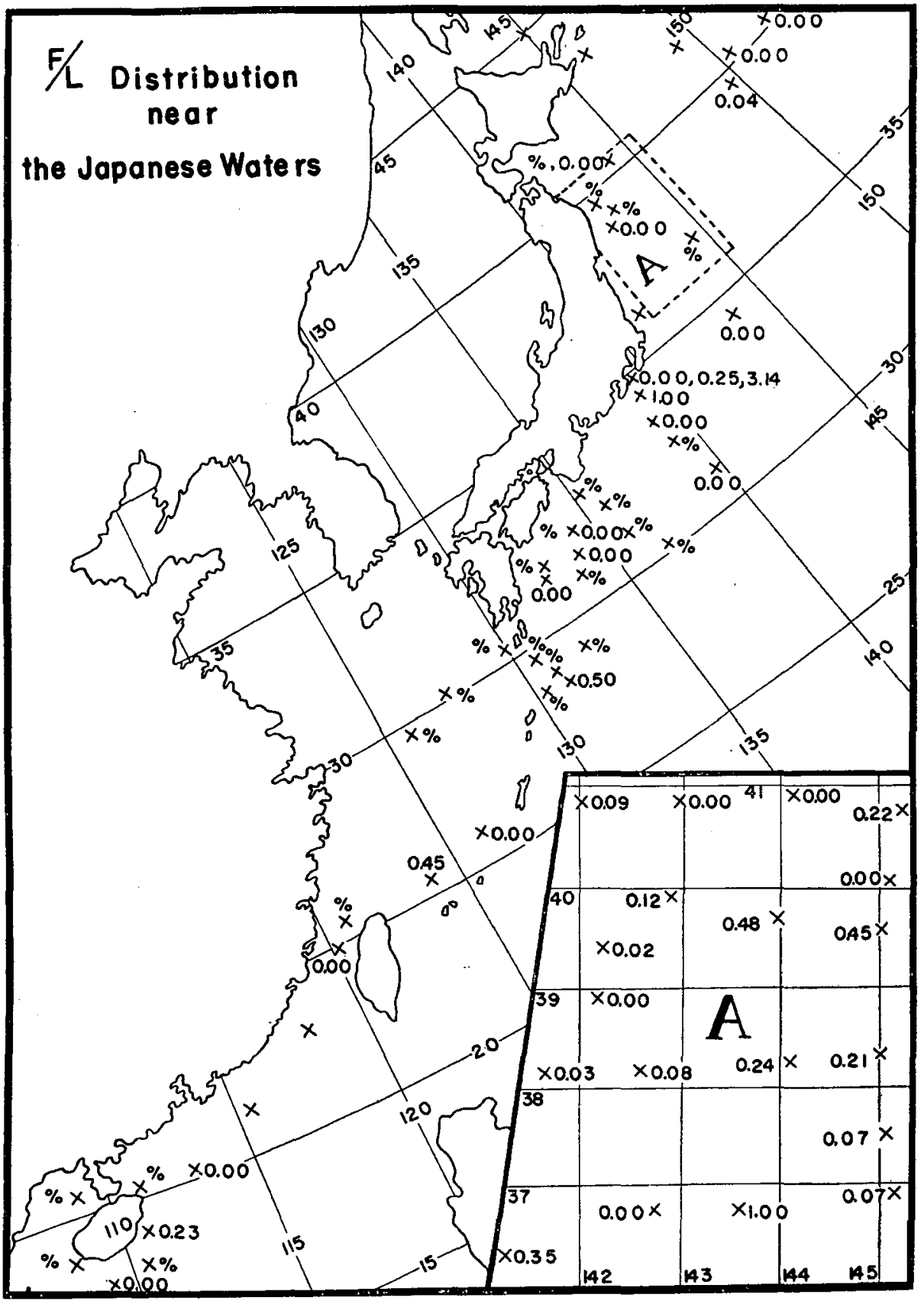

Fig. 9. Distribution of $\mathrm{F} / \mathrm{L}$ in the Japanese and its neighbouring waters. \% indicates that both $O$. longicauda and $O$. fusiformis were absent. 


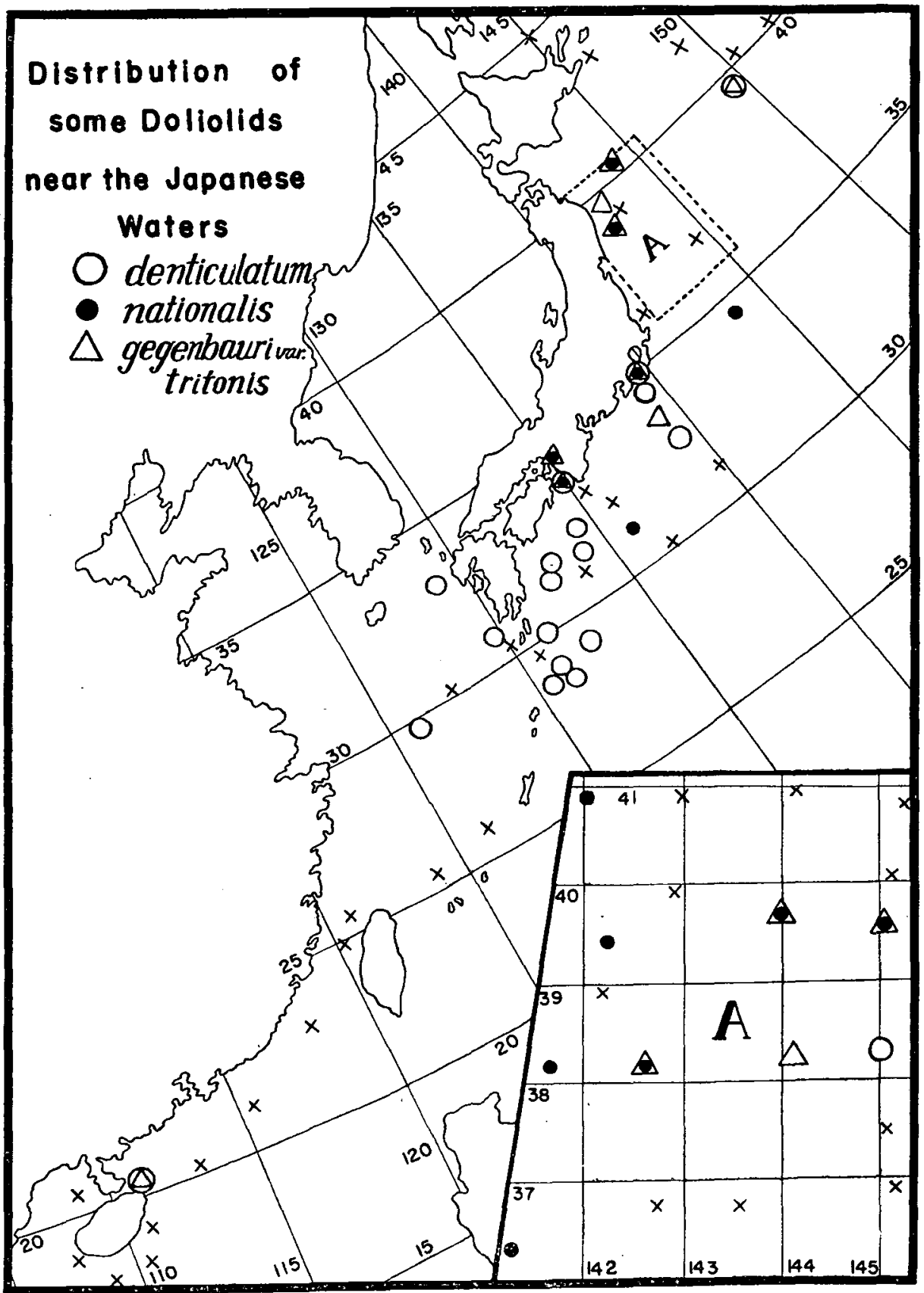

Fig. 10. Occurrences of Doliolum denticulatum. Doliolum nationalis and Dolioletta gegenbauri var. tritonis in the Japanese and its neighbouring waters. 


\begin{tabular}{|c|c|c|c|c|c|c|}
\hline & \multicolumn{2}{|c|}{ April $26-28$} & \multicolumn{2}{|c|}{ July 25} & \multicolumn{2}{|c|}{ September $25-27$} \\
\hline & $\begin{array}{c}\text { Surface } \\
\text { hauls }\end{array}$ & $\begin{array}{l}\text { Vertical } \\
\text { hauls }\end{array}$ & $\begin{array}{c}\text { Surface } \\
\text { hauls }\end{array}$ & $\begin{array}{c}\text { Vertical } \\
\text { hauls }\end{array}$ & $\begin{array}{c}\text { Surface } \\
\text { hauls }\end{array}$ & $\begin{array}{c}\text { Vertical } \\
\text { hauls }\end{array}$ \\
\hline O. longicauda & 7644 & 9200 & 1166 & 6110 & 4800 & 5810 \\
\hline o. fusiformis & - & 一 & 5795 & 528 & 1633 & 755 \\
\hline $\begin{array}{l}\text { O. fusiformis } \\
\text { f. cornutogastra }\end{array}$ & - & $\cdots$ & - & 30 & 113 & 20 \\
\hline O. gracilis & - & - & - & 12 & - & 67 \\
\hline o. dioica & 2318 & 728 & 1575 & 6 & - & * \\
\hline O. rufescens & - & - & - & 554 & 1575 & 655 \\
\hline o. parva & 一 & 一 & 一 & 35 & - & 11 \\
\hline O. cophocerca & - & - & - & 18 & 16 & 67 \\
\hline O. labradoriensis & - & 99 & - & - & - & - \\
\hline $\begin{array}{c}\text { Oikopleurids } \\
\text { damaged }\end{array}$ & 4 & 一 & 1272 & 376 & 938 & 355 \\
\hline M. huxleyi & - & - & - & 18 & 188 & - \\
\hline Steg. magnum & - & - & - & - & 71 & * \\
\hline Pelagopleura sp. & - & - & - & - & 12 & - \\
\hline Frit. haplostoma & - & - & - & 71 & 520 & 900 \\
\hline Frit. aberrans & - & - & - & $*$ & - & -- \\
\hline Frit. formica & - & - & - & 160 & 88 & 166 \\
\hline Frit. charybdae & - & - & - & * & - & 77 \\
\hline Frit. pellucida & - & - & 一 & 722 & 56 & 445 \\
\hline $\begin{array}{l}\text { Frit. borealis } \\
\text { f. intermedia }\end{array}$ & 一 & - & 60 & 122 & - & 107 \\
\hline $\begin{array}{l}\text { Frit. borealis } \\
\text { f. sargassi }\end{array}$ & - & - & - & 6 & - & 22 \\
\hline Frit. tenella & - & - & - & 795 & - & 296 \\
\hline Frit. venusta & - & - & - & 53 & - & 181 \\
\hline $\begin{array}{l}\text { Fritillarians } \\
\text { damaged }\end{array}$ & 一 & - & - & 316 & - & 67 \\
\hline App. sicula & - & - & 189 & 6 & - & * \\
\hline Numbers of samples & 23 & 9 & 19 & 17 & 24 & 9 \\
\hline
\end{tabular}

Table 13. Abundance of respective species, Frequency of Occurrence $\times$ Mean Percentage, in surface and vertical hauls in different seasons (Cruises to New Yamato Bank in the Japan Sea, 1950). 
3) Pelagic tunicates of the Japan Sea and the adjacent waters (Tables 13-18, Text-figs. 11-12).

The largest data about the pelagic tunicates fauna in the Japan Sea are found in ToKIOKA's paper (1951 b) dealing with the material got during the cruises to the New Yamato Bank. Here occurred 22 forms of appendicularians, of which O. dioica was the commonest form in Maizuru Bay (Table 14), while O. longicauda

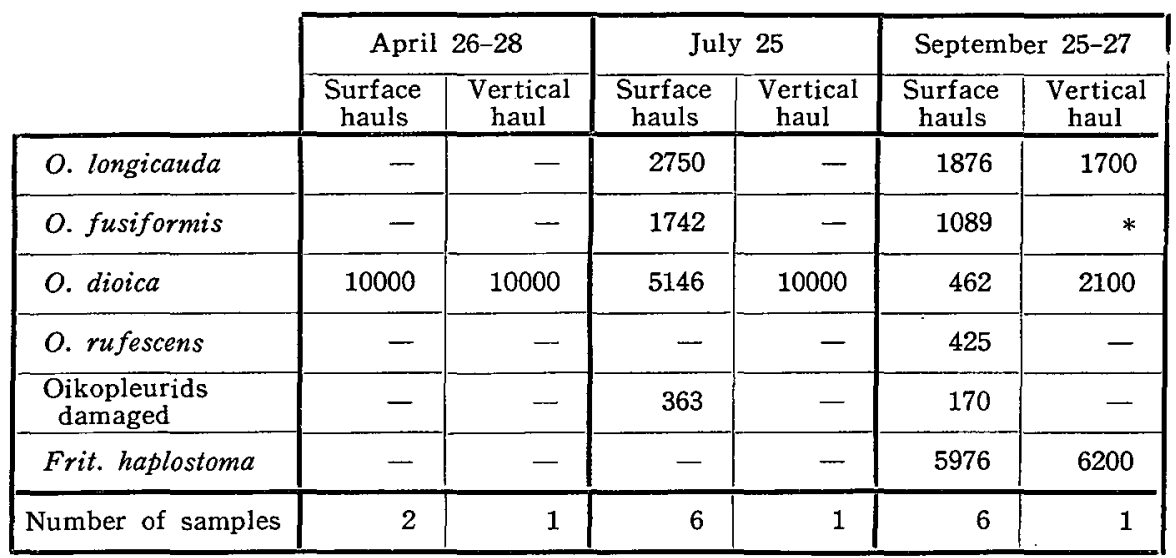

Table 14. Abundance of respective species, Frequency of Occurrence $\times$ Mean Percentage, in surface and vertical hauls in Maizuru Bay 1950.

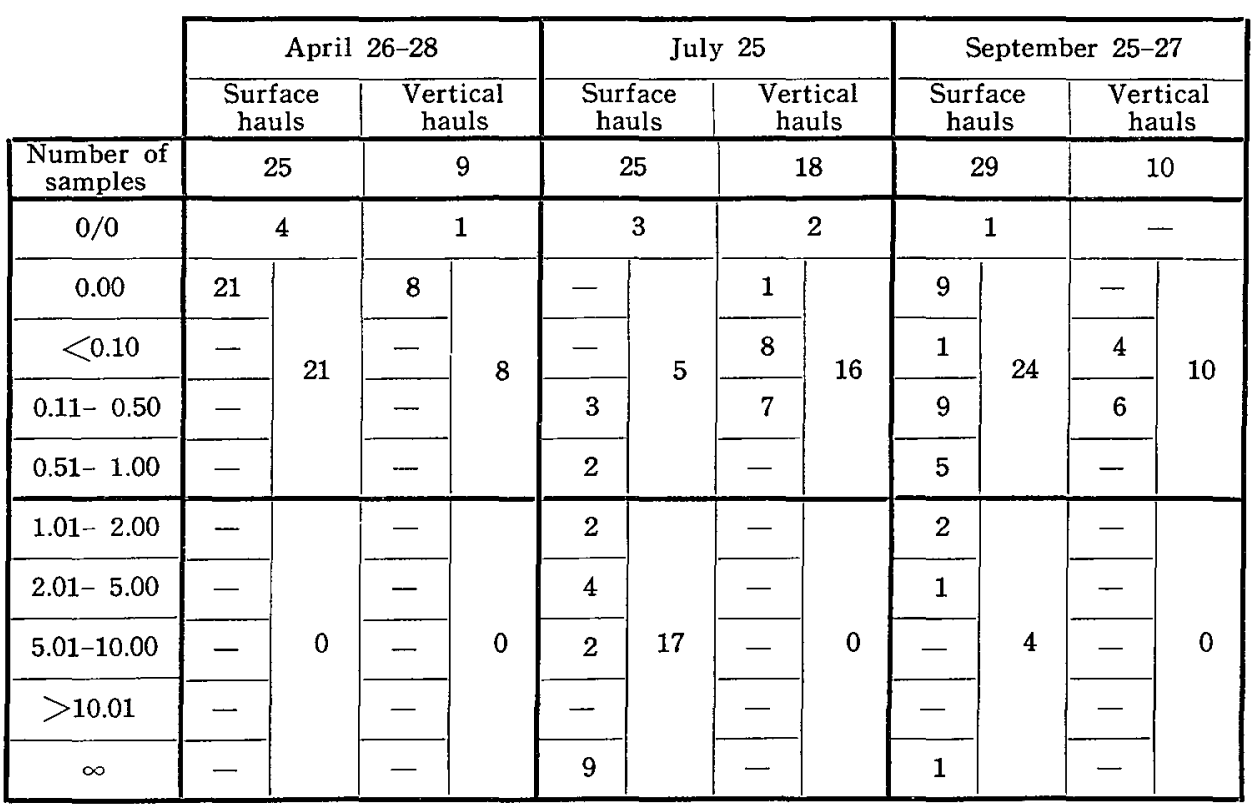

Table 15. Occurrence of respective values of $\mathrm{F} / \mathrm{L}$ in samples collected during the cruises to New Yamato Bank 1950. 
was the commonest one in the open sea (Table 13). During the warm season, July and September, when the Tusima Current, a branch of the Kurosio, was very vigorous along the Japan Sea coast of Honsyû Island, considerable numbers of $O$. fusiformis and $O$. rufescens occurred there, besides pretty many Frit. haplostoma, Frit. pellucida and Frit. tenella. M. huxleyi was found, too. While in the cold season, in April, when the Tusima Current was not so strong, the appendicularian fauna was quite simple; only $O$. dioica was prominent and followed by O. longicauda. Generally $\mathrm{F} / \mathrm{L}$ was very low excepting in the very surface layer of the water where $O$. fusiformis predominated over $O$. longicauda sometimes (surface hauls in July), this might be considered as indicating that the warm oceanic water was flowing along the surface (Table 15). Of thaliaceans only Doliolum nationalis occurred in significant numbers; Thalia democratica was found very rarely.

While I examined chaetognaths of the plankton collection made by the former Husan Fishery Experiment Station in Korea in the waters along the Korean coasts and in the waters extending from the western to southern Kyûsyû, I noted also the occurrences of pelagic tunicates in respective samples. This included the following data shown in Table 16. This seems to show the predominance of $O$. longicauda and frequent occurrences of $O$. fusiformis and $O$. rufescens in these waters, and also the frequent occurrence of Doliolum nationalis in the Japan Sea. YAMADA (1933) also showed the common occurrence of Doliolum nationalis in the Tyôsen Straits. O. rufescens was also found in a plankton sample collected off Yunohama of Yamagata Prefecture on Oct. 16, 1935. Besides the above-mentioned data, many plankton samples were collected by the Synpûmaru of the Kobe Marine Observatory in this sea and some parts of the 1930 collection were examined to obtain data of pelagic tunicates. Most of samples were collected by vertical hauling from 40,50 or $60 \mathrm{~m}$ to the surface, but some ones were collected by $100-0 \mathrm{~m}$ hauling. The results are shown in Table 17. This shows evidently that $O$. fusiformis was extremely scarce at most stations in the sea, although it sometimes increased at some stations in the Tugaru Straits. In a word, $O$. longicauda and $O$. dioica were the remarkable appendicularians found most commonly in the collection; besides, O. labradoriensis was found usually in somewhat deeper water. Only Doliolum nationalis was met with in examined samples of the present collection. This doliolid seems to be prevailing in the Japan Sea, as Iizuka \& others (1951) and Motoda \& Anraku (1951) report the unusual dense population of this species occurred around the southwestern corner of Hokkaidô Island and being extended to the north of Isikari Bay (ca. $44^{\circ} 10^{\prime} \mathrm{N} \times 141^{\circ} 04^{\prime} \mathrm{E}$ ) in the spring to summer of 1950 . 
Table 16.

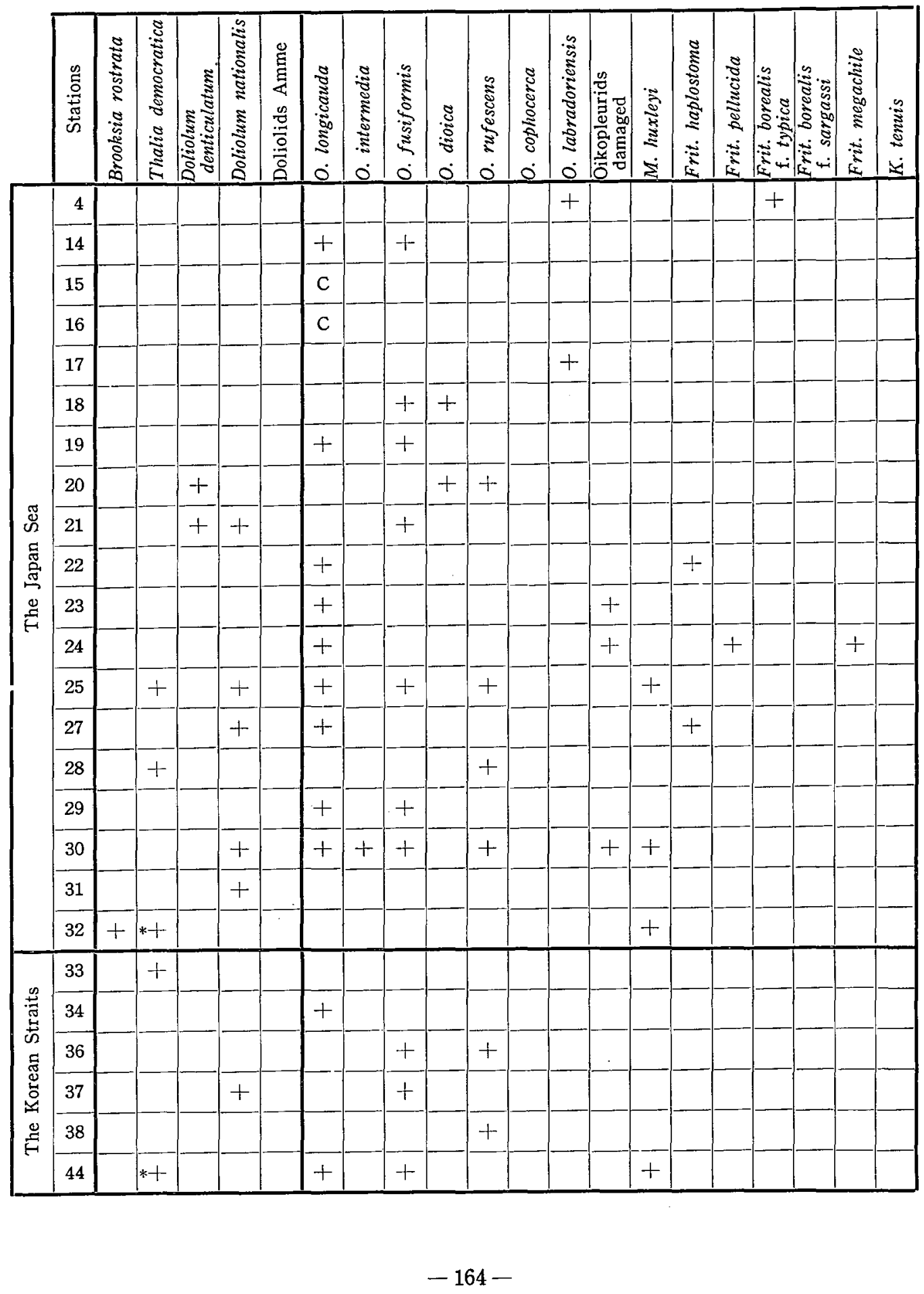


Table 16. (continued)

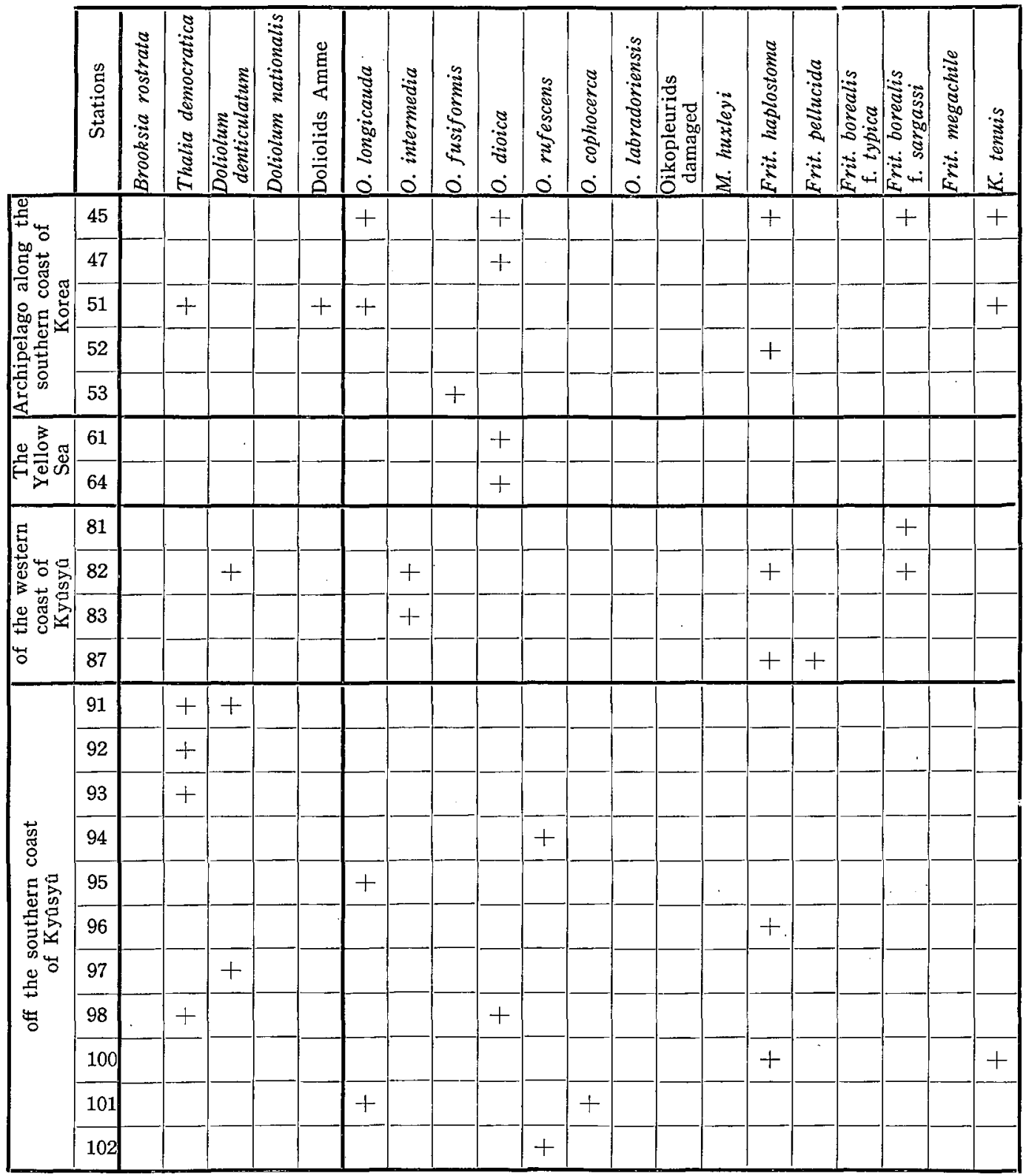

Occurrences of pelagic tunicates in the plankton samples collected by the former Husan Fishery

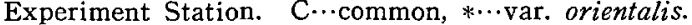

St. $14\left(40^{\circ} 35^{\prime} \mathrm{N} \times 129^{\circ} 35^{\prime} \mathrm{E}\right) \cdots$ the northern-most locality for O. longicauda and $O$. fusiformis, St. 20 $\left(38^{\circ} 15^{\prime} \mathrm{N} \times 129^{\circ} 45^{\prime} \mathrm{E}\right) \cdots$ the northern-most locality for Doliolum deticulatum and $O$. rufescens, St. 21 $\left(38^{\circ} 15^{\prime} \mathrm{N} \times 130^{\circ} 45^{\prime} \mathrm{E}\right) \cdots$ the northern-most locality for Doliolum nationalis, St. $22\left(38^{\circ} 15^{\prime} \mathrm{N} \times 131^{\circ}\right.$ $\left.45^{\prime} \mathrm{E}\right) \cdots$ the northern-most locality for Frit. haplostoma, St. $24\left(37^{\circ} 15^{\prime} \mathrm{N} \times 129^{\circ} 45^{\prime} \mathrm{E}\right) \cdots$ the northernmost locality for.Frit. pellucida, St. $25\left(37^{\circ} 15^{\prime} \mathrm{N} \times 130^{\circ} 45^{\prime} \mathrm{E}\right) \cdots$ the northern-most locality for $M$.

huxleyi. For positions of other stations, see TokIOKA, T. (1940): The chaetognath fauna of the waters of western Japan. Rec. Oceanogr. Works Japan, Vol. 12, No. 1, pp. 12-22. 


\begin{tabular}{|c|c|c|c|c|c|c|c|c|c|c|c|}
\hline & 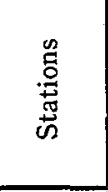 & 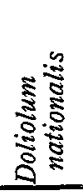 & 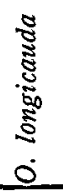 & 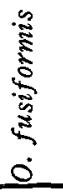 & 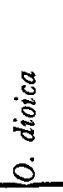 & 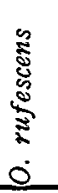 & 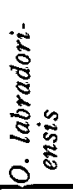 & 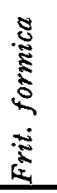 & 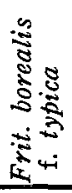 & 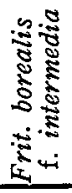 & 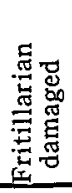 \\
\hline \multirow{11}{*}{ 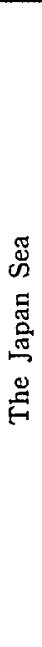 } & 7 & & 140 & & 11 & & & & & & \\
\hline & 9 & 2 & 190 & 8 & & & & & & & \\
\hline & $10-12$ & 1 & 20 & 4 & & 5 & 1 & & 1 & & 1 \\
\hline & $13-14$ & & 141 & & 39 & & & & & & \\
\hline & $26-27$ & & 7 & & & & 17 & & 3 & 30 & \\
\hline & $36-37$ & & & & & & 4 & & & & \\
\hline & 37 & & 78 & & 5 & & 14 & & & & \\
\hline & $56-58$ & & 1 & & 9 & & 3 & & & & \\
\hline & $64-65$ & & 76 & & 14 & & & & & & \\
\hline & 68 & & 65 & & 1 & & 22 & & & & \\
\hline & 69 & & 63 & & 7 & & 6 & & & & \\
\hline \multirow{10}{*}{ 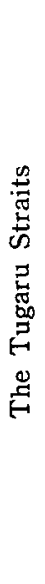 } & $72-74$ & & 14 & & 13 & & 15 & & & & \\
\hline & 75 & & 16 & & 27 & & 16 & & & & \\
\hline & 76 & & & & 6 & & 7 & & & & \\
\hline & $79-80$ & & 82 & & 27 & & 34 & & & & \\
\hline & 94-95 & 24 & 32 & 24 & 3 & 2 & & 1 & & & \\
\hline & $94-97$ & & 17 & & 3 & & 1 & & & & \\
\hline & $98-100$ & 4 & 53 & & & & 1 & & & & \\
\hline & $101-102$ & & 31 & 23 & & & & & & & \\
\hline & 104 & & 4 & & & 1 & & & & & \\
\hline & 105 & & & & & 1 & & & & & \\
\hline \multirow{4}{*}{ 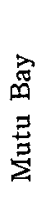 } & 82 & & 92 & & 17 & & 11 & & & & \\
\hline & 83 & & 71 & & 3 & & & & & & \\
\hline & $88-89$ & & 3 & & & & 1 & & & & \\
\hline & 90 & & & & & & 2 & & & & \\
\hline
\end{tabular}

Table 17. Occurrences of pelagic tunicates in the plankton samples collected by the Syunpü. maru 1930.

St. $12\left(38^{\circ} 34^{\prime} \mathrm{N} \times 128^{\circ} 52^{\prime} 30^{\prime \prime} \mathrm{E}\right) \cdots$ the northern-most locality for $O$. fusiformis and O. rufescens, St. $27\left(41^{\circ} 14^{\prime} 20^{\prime \prime} \mathrm{N} \times 129^{\circ} 48^{\prime} 05^{\prime \prime} \mathrm{E}\right)$...the northern-most locality for O. longicauda; both in the Japan Sea samples. 


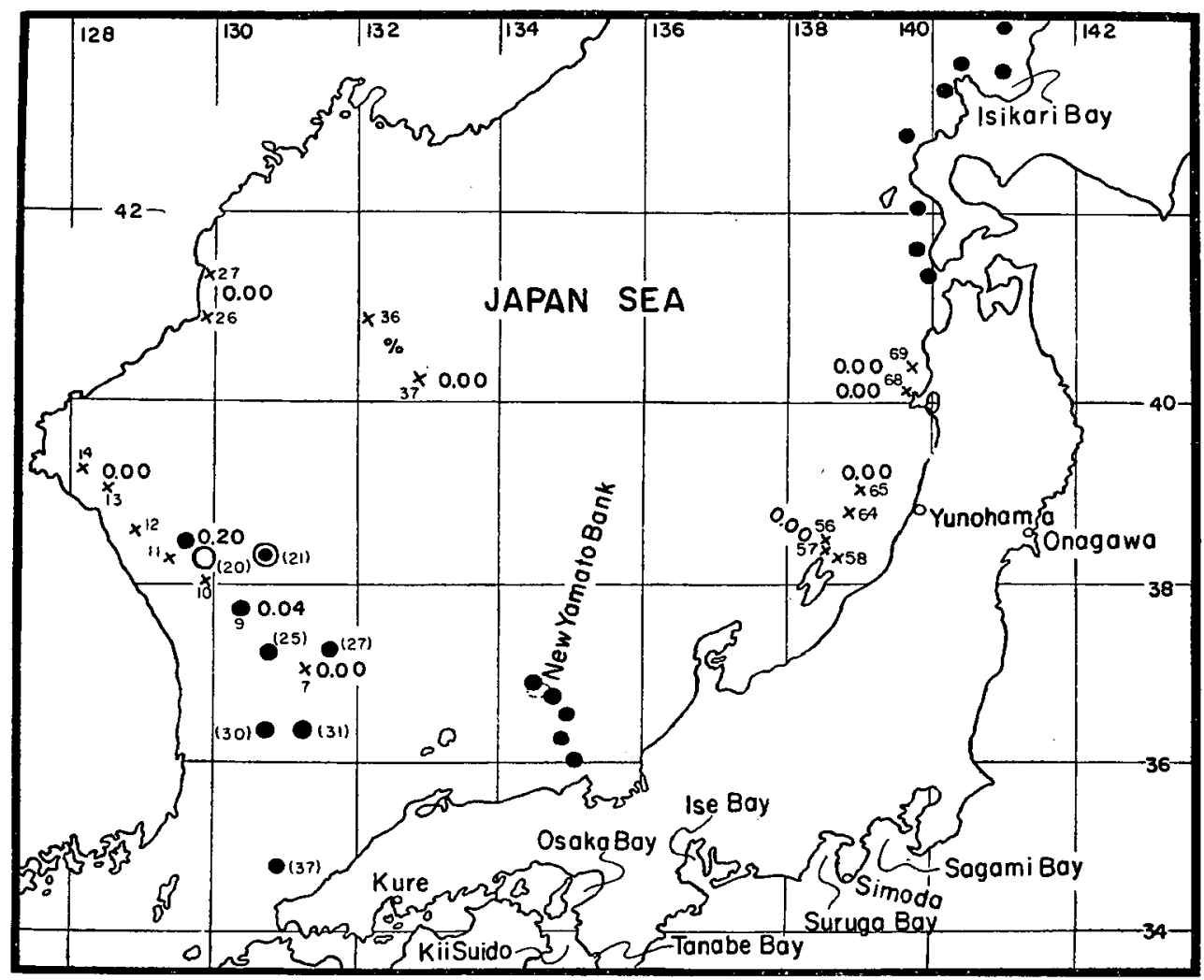

Fig. 11. Distributions of $\mathrm{F} / \mathrm{L}$ and two doliolids in the Japan Sea. Open circle $\cdots$ Doliolum denticulatum, solid circle...Doliolum nationalis, large numerals $\cdots \mathrm{F} / \mathrm{L}$ obtained by the Syunpû-maru, small numerals $\cdots$ station numbers of the Syunpû-maru Expedition 1930, parenthesized small numerals..station numbers of the expedition made by the former Husan Fishery Experiment Station in Korea (ToKIOKA 1940). 


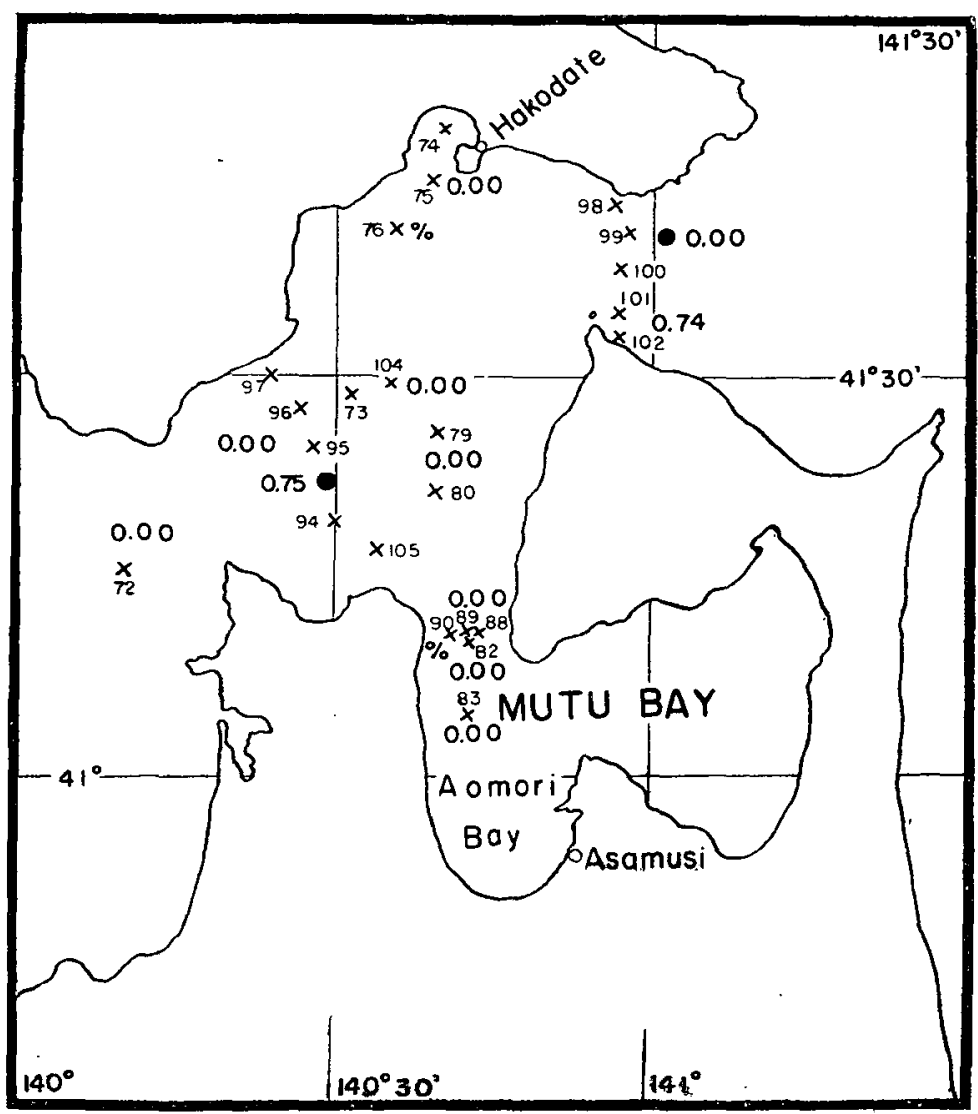

Fig. 12. Distributions of F/L and Doliolum nationalis (solid circle) in the Tugaru Straits during the Syunpo-maru Expedition 1930. Large numerals $\cdots$ values of $\mathrm{F} / \mathrm{L}$, small numerals $\cdots$ station numbers.

Occurrences of $O$. longicauda and Doliolum nationalis in the Tugaru Straits is recognized by KокUво (1926), too, on the plankton samples collected June

\begin{tabular}{|c|c|c|}
\hline & August 15,1930 & March 1, 1939 \\
\hline o. longicauda & + & 4 \\
\hline O. dioica & + & 6 \\
\hline O. labradoriensis & - & 45 \\
\hline Frit. borealis f. typica & - & 5 \\
\hline Fritillaria sp. (damaged) & - & 1 \\
\hline
\end{tabular}

Table 18. Appendicularians in Aomori Bay. 
21-25, 1924. As to the appendicularian fauna in Aomori Bay, the inner part of Mutu Bay facing the Tugaru Straits, there are the preceding two data. Yamada (1933) showed the occurrence of $O$. dioica in the Yellow Sea in one of the distribution maps of plankton of that sea. My data in Table 16 show also that this species was the only appendicularian found in the crassa-water of the Yellow Sea. 4) Appendicularian faunas and records of some other pelagic tunicates at various parts of the coasts of Japanese islands (Tables 19-21).

i-Etorohu Island. Four specimens of O. longicauda were found in the plankton sample which was collected by Dr. R. Yosir on Aug. 20, 1933 off Iriribusi (入里節) of this island of the Tisima Islands, a small village facing the Pacific and located about $35 \mathrm{~km}$ south to Hitokappu (単冠) Bay.

ii-Hokkaidô Island. The occurrence of O. dioica in Lake Notoro (能取) and that of Oikopleura sp. (probably $O$. dioica) in Lake Onne-numa (温根沼), both facing the Okhotsk Sea, are reported by Hokkaido Fishery Experiment Station (1934). The water temperature and chlorinity in these lakes at the time when the samples were collected were:

\begin{tabular}{|l|c|c|c|}
\cline { 2 - 4 } \multicolumn{1}{c|}{} & Date & Water Temperature & Chlorinity \\
\hline Notoro & June 1932 & $11.5-14.6^{\circ} \mathrm{C}$ & $14.490-17.475 \%$ \\
\hline Onne-numa & Oct. 1932 & $12.1-13.0^{\circ} \mathrm{C}$ & $15.810-17.600 \%$ \\
\hline
\end{tabular}

Table 19. Water temperature and chlorinity in the lakes of Hokkaidô Island, where $O$. dioica was collected.

iii-Onagawa (女川) Bay. Two plankton samples from the bay situated on the Pacific coast of the north-eastern part of Honsyu Island were examined and found containing only the following two forms.

\begin{tabular}{|l|c|c|}
\cline { 2 - 3 } & May 19, 1937 & Oct. 27, 1939 \\
\hline O. longicauda & $40-50$ & 25 \\
\hline O. dioica & 3 & 1 \\
\hline
\end{tabular}

Table 20. Occurrence of appendicularians in Onagawa Bay.

iv-The bays of Sagami and Suruga. Throughout AIDA's paper (1907) dealing with the material collected in or near Misaki Harbour of Sagami Bay and ToKioKA's material (1940) came from both of Sagami and Suruga bays, seventeen appendicularians have been reported from this area (Table 21). Both Doliolum denticulatum and Doliolum nationalis are known from this area. Sisido (1899) recognized the occurrence of Dolioletta gegenbauri var. tritonis at Misaki in the summer of 1898. Solitary forms of Thalia democratica were mostly represented by var. orientalis during my stay at the Mitsui Institute of Marine Biology for 1936-1938. 


\begin{tabular}{|c|c|c|}
\hline . & $\begin{array}{l}\text { The Bays of Sagami } \\
\text { and Suruga }\end{array}$ & The vicinity of Seto \\
\hline O. longicauda & + & + \\
\hline o. intermedia & + & + \\
\hline o. fusiformis & + & + \\
\hline $\begin{array}{l}\text { O. fusiformis } \\
\text { f. cornutogastra }\end{array}$ & + & + \\
\hline O. dioica & + & + \\
\hline O. rufescens & + & + \\
\hline O. cophocerca & + & + \\
\hline O. albicans & - & + \\
\hline M. huxleyi & + & + \\
\hline Steg. magnum & + & + \\
\hline Alth. tumida & - & + \\
\hline Frit. haplostoma & + & + \\
\hline Frit. formica f. digitata & + & + \\
\hline Frit. fraudax & - & + \\
\hline Frit. pellucida & + & + \\
\hline $\begin{array}{l}\text { Frit. borealis } \\
\text { f. intermedia } \\
\end{array}$ & - & + \\
\hline Frit. borealis f. sargassi & + & + \\
\hline Frit. megachile & + & + \\
\hline Frit. tenella & + & - \\
\hline Frit. venusta & - & + \\
\hline T. fertilis & + & + \\
\hline App. sicula & - & + \\
\hline K. tenuis & + & - \\
\hline Number of species & 17 & 21 \\
\hline
\end{tabular}

Table 21. Appendicularians occurring in the Bays of Sagami and Suruga and in the vicinity of Seto, Kii.

$\mathrm{v}$-The vicinity of the Seto Marine Biological Laboratory. The laboratory is situated near the end of the peninsula embracing the southern side of Tanabe Bay facing the Kii-Channel. From the vicinity of Seto, where the laboratory is located, twenty-one appendicularians have been reported; two of them, O. albicans and Althoffia tumida, were collected in the far oceanic water off Cape Sionomisaki. The collections made in the present and preceding regions constituted the most 
part of the material on which my general consideration on Japanese appendicularian fauna was based $(1955 \mathrm{c})$, and consequently the relative abundance of respective species are seen in that paper. In an inlet at Yukawa near Katu-ura, situated at a short distance east from Cape Sionomisaki, only $O$. dioica is found commonly. This species is very common in the inner parts of Tanabe Bay, too, where a quantity of Frit. haplostoma may join to the population sometimes (Tok IOKA 1940, p. 9). Of thaliaceans occurring in this vicinity, Dolioletta gegenbauri var. tritonis is the commonest of doliolids, although both Doliolum denticulatum and Doliolum nationalis occur, too; and Thalia democratica and Salpa fusiformis are the most frequent visitors of salps.

$\mathrm{vi}$-Ise Bay. I had a chance to examine a plankton sample collected in this bay on March 26, 1938 and found $O$. dioica and $O$. fusiformis in it.

vii-Ôsaka Bay and Kii-Channel. During my observations on chaetognaths and pelagic tunicates in this region (1939), O. dioica was prevailing in Ôsaka Bay, besides only a single specimen of $O$. longicauda was found in the collection made in the Bay. On the other hand, Doliolum nationalis and Dolioletta gegenbauri var. tritonis occurred at considerably higher frequencies, namely 53\% and 59\% respectively, although their occurrences were roughly confined to the western half of the Bay. The ratio $\mathrm{F} / \mathrm{L}$ was distributed in the Kii-Channel on Nov. 20, 1938 as 0.00 off Yuasa and Kii Yura, 0.03 off Gobô and 0.08 off Minabe, here the localities are arranged in the order from the north adjoining Osaka Bay to the south opening to the ocean.

viii-The Inland Sea. $O$. dioica is prevailing in most parts of the Inland Sea. For instance, in each of the six plankton samples collected Aug. 3-6, 1938 in the region stretching from the area off Kure to Hiuti-nada situated nearly at the middle of the Inland Sea, I found a pretty number of $O$. dioica, but $O$. longicauda only in a single sample from the Sound of Ondono-seto. A doliolid Amme was found in a sample collected off Kure, but the specific identification of this Amme was not made.

\section{OCCURRENCE OF PELAGIC TUNICATES IN THE WATERS ADJOINING TO THE NORTH PACIFIC}

\section{(Appendix Tables 13-14, Tables 22-27)}

1) Pelagic tunicates of the Siboga area (Table 22).

IHLE (1908) found fourteen species of appendicularians in 69 plankton samples of the Siboga Expedition. O. longicauda was the commonest species and followed by $M$. huxleyi and $O$. rufescens. O. fusiformis was much less than O. longicauda, occurring at the frequency of only 20\%. Among fritillarians, Frit. pellucida occurred most frequently, being followed by Frit. formica and Frit. borealis f. sargassi.

Doliolum denticulatum, Doliolum nationalis and Dolioletta gegenbauri var. tritonis were found distributing in the Siboga area (IHLE 1910), and the first and the last 
of these three were also recorded near Amboina (BEDot 1909, p. 168). Doliolum denticulatum was quite common in this area and occurred at the frequency of $88 \%$, while other two were rather rare; the frequency of occurrence (F.O.) of Doliolum nationalis was only $5 \%$ and that of Dolioletta gegenbauri var. tritonis was

\begin{tabular}{|l|c|}
\hline \multicolumn{1}{|c|}{ Species } & Frequency of Occurrance \\
\hline Frit. pellucida & $25 \%$ \\
\hline Frit. haplostoma & 1.4 \\
\hline Frit. formica & 12 \\
\hline Frit. megachile & 1.4 \\
\hline Frit. tenella & 7 \\
\hline Frit. venusta (described as Frit. bicornis) & 4 \\
\hline Frit. borealis f. sargassi (described as f. ritteri) & 12 \\
\hline M. huxleyi & 64 \\
\hline O. longicauda & 84 \\
\hline ?O. intermedia (described as O. microstoma) & 1.4 \\
\hline O. fusiformis & 20 \\
\hline O. cophocerca & 20 \\
\hline O. rufescens & 58 \\
\hline Steg. magnum & 26 \\
\hline
\end{tabular}

Table 22. Frequency of occurrence of respective species of appendicularians of the Siboga Expedition.

14\%. Of the thirteen salps known from this area, Thalia democratica was the commonest $($ F.O. $=81 \%$ ), then followed Salpa cylindrica $($ F. O. $=41 \%)$, Salpa fusiformis including f. aspera (F. O.=27\%), Cyclosalpa pinnata (F. O.=24\%), Ritteriella amboinensis (F.O.=19\%), Brooksia rostrata (F.O.-15\%) and Iasis zonaria (F. O. $-11 \%$ ).

2) Pelagic tunicates of the Arafura Sea (Appendix Table 13, Tables 23-24).

As to the appendicularian fauna of this sea, I gave preliminarily a list of species occurred in a small collection made by $\mathrm{Mr}$. S. WADA in 1939 (TokiokA 1942); nine species, O. longicauda, O. intermedia, O. fusiformis, O. fusiformis $\mathrm{f}$. cornutogastra, O. dioica, O. rufescens, $M$. huxleyi, Steg. magnum and Frit. borealis $\mathrm{f}$. sargassi, were included in it. $O$. longicauda and O.rufescens were the commonest forms and $M$. huxleyi was found rather richly. Later, a comparatively large material collected by Mr. Z. SAGARA in 1955 in the western part of this waters adjoining to the Timor Sea was studied, and results of the examination on this 
collection were published in my previous paper of $1956 \mathrm{~b}$ in detail. There were nineteen identified species; the abundance of respective species is seen in Table 1 (AR). The most prominent species was $O$. longicauda, next $O$. rufescens, Frit. borealis f. sargassi (mostly smaller individual) and $O$. fusiformis f. cornutogastra and followed by App. sicula, $O$. dioica and $O$. fusiformis. $O$. fusiformis

\begin{tabular}{|c|c|c|c|c|}
\hline & The Timor Sea & West of $130^{\circ} \mathrm{E}$ & $\begin{array}{c}\text { Between } 130^{\circ} \mathrm{E} \\
\text { and } 133^{\circ} \mathrm{E}\end{array}$ & East of $133^{\circ} \mathrm{E}$ \\
\hline O. longicauda & 100 & 100 & 77 & 100 \\
\hline o. fusiformis & 100 & 25 & 7 & 25 \\
\hline $\begin{array}{l}\text { O. fusiformis } \\
\text { f. cornutogastra }\end{array}$ & 33 & 94 & 54 & 90 \\
\hline O. dioica & 17 & 31 & 31 & 50 \\
\hline O. rufescens & 83 & 44 & 77 & 70 \\
\hline O. cophocerca & 50 & 38 & 0 & 0 \\
\hline M. huxleyi & 17 & 13 & 0 & 10 \\
\hline Steg. magnum & 17 & 19 & 0 & 5 \\
\hline Frit. haplostoma & 50 & 25 & 8 & 15 \\
\hline $\begin{array}{c}\text { Frit. formica } \\
\text { f. digitata }\end{array}$ & 50 & 0 & 0 & 0 \\
\hline Frit. pellucida & 17 & 0 & 0 & 0 \\
\hline $\begin{array}{l}\text { Frit. borealis } \\
\text { f. sargassi }\end{array}$ & 100 & 94 & 46 & 85 \\
\hline App. sicula & 50 & 56 & 46 & 70 \\
\hline $\begin{array}{c}\text { Number of } \\
\text { samples }\end{array}$ & 6 & 16 & 13 & 20 \\
\hline
\end{tabular}

Table 23. Frequency of occurrence of respective important species in different sections of the surveyed area in or near the Arafura Sea.

\begin{tabular}{|c|c|c|c|c|c|c|c|c|}
\hline . & \multicolumn{2}{|c|}{ The Timor Sea } & \multicolumn{2}{|c|}{ West of $130^{\circ} \mathrm{E}$} & \multicolumn{2}{|c|}{$\begin{array}{c}\text { Between } 130^{\circ} \mathrm{E} \\
\text { and } 133^{\circ} \mathrm{E}\end{array}$} & \multicolumn{2}{|c|}{ East of $133^{\circ} \mathrm{E}$} \\
\hline $\begin{array}{l}\text { Number of } \\
\text { samples }\end{array}$ & \multicolumn{2}{|c|}{6} & \multicolumn{2}{|c|}{16} & \multicolumn{2}{|c|}{13} & \multicolumn{2}{|c|}{20} \\
\hline $0 / 0$ & \multicolumn{2}{|c|}{-} & \multicolumn{2}{|c|}{-} & \multicolumn{2}{|c|}{3} & \multicolumn{2}{|c|}{-} \\
\hline 0.00 & - & \multirow{4}{*}{4} & 12 & \multirow{4}{*}{16} & 9 & \multirow{4}{*}{10} & 15 & \multirow{4}{*}{20} \\
\hline$<0.10$ & 1 & & 3 & & 1 & & 4 & \\
\hline $0.11-0.50$ & 2 & & - & & - & & 1 & \\
\hline $0.51-1.00$ & 1 & & 1 & & - & & - & \\
\hline $1.01-2.00$ & 2 & 2 & - & 0 & - & 0 & - & 0 \\
\hline
\end{tabular}

Table 24. Occurrences of respective values of $\mathrm{F} / \mathrm{L}$ in different sections of the surveyed area in or near the Arafura Sea. 
seemed to trend towards the decrease to the east, this may be seen rather clearly in Table 24 showing the distribution of $\mathrm{F} / \mathrm{L}$ in respective sections of the surveyed area. O. cophocerca, Frit. formica f. digitata and Frit. pellucida were confined to the Timor Sea and its adjoining region during this survey. While, O. fusiformis f. cornutogastra, $O$. dioica and $A p p$. sicula seemed to increase towards the eastern part where the neritic character of the water was considered to be stronger than in the western portion. O. rufescens, Frit haplostoma and Frit. borealis f. sargassi seemed to be distributed rather evenly.

Of thaliaceans, Dolioletta gegenbauri and Doliolum denticulatum were the species occurred in significant numbers in this collection; the former was distributed rather evenly in the surveyed area excepting the Timor Sea, while the latter occurred chiefly in the Timor Sea.

3) Pelagic tunicates in the waters off eastern Australia (Table 25).

(1) The Great Barrier Reef Region. The pelagic tunicates of the Great Barrier Reef Expedition 1928-29 were identified by Hastings (1931) and the occurrence of respective species was studied in detail by Russell and Colman (1935). There occurred nine species of Thaliacea and eight of Appendicularia. Of doliolids, Doliolum denticulatum was the commonest, the frequency of occurrence of this species throughout 121 samples consisting of oblique hauls of the 1-metre stramin net and those of the coarse silk tow-net was $74 \%$, while other two, Dolioletta gegenbauri and its variety tritonis, occurred only insignificantly. Among salps, Thalia democratica was the commonest one, its frequency of occurrence attained $70 \%$ (of 121 samples); other five species were Cyclosalpa pinnata, Brooksia rostrata, Iasis zonaria, Salpa cylindrica and Pegea confoederata.

In appendicularians, $O$. rufescens was the commonest, its frequency of occurrence was $54 \%$ (of 121 samples). M. huxleyi occurred very frequently (F.O.66\%), but it was much less than $O$. rufescens. O. longicauda was found in 12 of 74 samples (F. O.-16\%) and Steg. magnum in 29 of 121 samples (F. O.-24\%), both in very small numbers. $O$. fusiformis, Frit. haplostoma, Frit. pellucida and Frit. borealis f. intermedia occurred only insignificantly. Abundant occurrences of large-sized Megalocerus and Stegosoma and of O. rufescens whose house seems to be tough enough against the towing by a coarse net and contrarily the scarcity of small-sized forms may be safely attributable to the using of coarse stramin or silk nets. HASTINGS (1931) mentions that "the absence of Oikopleura cophocerca is rather surprising", but this might be related with the complete absence of this species in the eastern part of the Arafura Sea (Table 23).

(2) South eastern Australian waters (Table 25). The large collection made by the research vessel $M$. V. Warreen of the Commonwealth Council for Scientific and Industrial Research in the south eastern Australian area, extending from the tropic of Capricorn to part of the South Australian coast, was studied by Thompson (1948) in detail. Of two doliolids, Doliolum denticulatum (including 
D. nationalis) was much more abundant than Dolioletta gegenbauri (including var. tritonis), though the distribution of the latter extended more to the south. HERDMAN (1888) reported the occurrence of Doliolum denticulatum in the Bass Straits, but this is a questionable record. Of 18 salps, Thalia democratica was the commonest. Ihlea magalhanica and Salpa fusiformis were abundant in the southern half of the surveyed area, Traustedtia multitentaculata, Brooksia rostrata, Salpa maxima, Salpa cylindrica, Iasis zonaria and Pegea confoederata occurred fairy abundantly in the order of this listing.

Of 22 species of appendicularians, $O$. longicauda was the outstanding species and other important species were $O$. fusiformis, Frit. pellucida and O. rufescens.

\begin{tabular}{|c|c|c|c|c|c|c|c|c|c|c|c|}
\hline O. longicauda & $\ldots$ & $\ldots$ & $\ldots$ & $\cdots$ & $\ldots$ & $\ldots$ & $\ldots$ & $\ldots$ & $\ldots$ & $\ldots$ & 269,912 \\
\hline o. fusiformis & & $\ldots$ & $\ldots$ & $\ldots$ & $\ldots$ & $\ldots$ & $\ldots$ & $\ldots$ & $\ldots$ & $\ldots$ & 57,485 \\
\hline Frit. pellucida & $\ldots$ & $\ldots$ & $\ldots$ & $\ldots$ & $\ldots$ & $\ldots$ & $\ldots$ & $\ldots$ & $\ldots$ & $\ldots$ & 46,654 \\
\hline O. rufescens & $\cdots$ & $\ldots$ & $\ldots$ & $\ldots$ & $\ldots$ & $\ldots$ & $\ldots$ & $\ldots$ & $\ldots$ & $\ldots$ & 45,718 \\
\hline O. dioica $\quad \ldots$ & $\cdots$ & $\cdots$ & $\cdots$ & $\cdots$ & $\cdots$ & $\cdots$ & $\cdots$ & $\cdots$ & $\cdots$ & $\cdots$ & 15,159 \\
\hline$M$. huxleyi... & $\ldots$ & $\ldots$ & $\cdots$ & $\cdots$ & $\cdots$ & $\cdots$ & $\ldots$ & $\cdots$ & $\ldots$ & $\ldots$ & 11,294 \\
\hline Steg. magnum & $\ldots$ & $\ldots$ & $\ldots$ & $\ldots$ & $\ldots$ & $\ldots$ & $\ldots$ & ... & $\ldots$ & $\ldots$ & 9,751 \\
\hline O. albicans & $\ldots$ & $\ldots$ & $\ldots$ & $\ldots$ & $\ldots$ & $\ldots$ & $\ldots$ & $\ldots$ & $\ldots$ & $\ldots$ & 8,897 \\
\hline O. cophocerca & $\cdots$ & $\ldots$ & $\ldots$ & $\cdots$ & $\ldots$ & $\cdots$ & $\ldots$ & $\cdots$ & ... & $\cdots$ & 3,597 \\
\hline O. cornutogastr & & $\cdots$ & $\cdots$ & $\cdots$ & $\cdots$ & $\cdots$ & $\cdots$ & $\cdots$ & $\cdots$ & $\cdots$ & 3,483 \\
\hline Frit. formica & $\cdots$ & $\ldots$ & $\ldots$ & $\ldots$ & $\ldots$ & $\ldots$ & $\ldots$ & ... & ... & $\ldots$ & 1,580 \\
\hline O. parva $\quad \ldots$ & $\ldots$ & $\ldots$ & $\ldots$ & $\cdots$ & $\ldots$ & $\cdots$ & $\ldots$ & $\ldots$ & $\ldots$ & $\cdots$ & 1,536 \\
\hline o. intermedia & $\cdots$ & $\ldots$ & $\ldots$ & $\cdots$ & $\ldots$ & $\ldots$ & $\cdots$ & $\cdots$ & ... & $\ldots$ & 1,263 \\
\hline Frit. borealis f. & & gassi & & $\ldots$ & $\ldots$ & $\ldots$ & $\ldots$ & $\cdots$ & $\ldots$ & $\ldots$ & 815 \\
\hline Frit. haplostoma & & $\ldots$ & $\ldots$ & $\ldots$ & $\ldots$ & $\ldots$ & $\ldots$ & $\ldots$ & $\ldots$ & $\ldots$ & 300 \\
\hline
\end{tabular}

Table 25. Total individuals of respective fifteen important species of appendicularians occurring in south-eastern Australian waters. (THOMPSON 1948)

Totals of individuals of respective fifteen species occurred in the surveyed area in significant numbers are quoted here from ThompSon's book (p. 166). Relatively large population of $O$. dioica and low value of $F / L(0.21)$ seem to show that the above totals obtained throughout the whole collection might be strongly influenced by relatively frequent hauls made in the coastal waters. Small populations of Frit. borealis f. sargassi and Frit. haplostoma are rather impressive when these are compared with those in the adjacent waters such as the Arafura Sea and the Marshall Islands area surveyed by the Syunkotu-maru. The complete absence of $A p p$. sicula in this area is quite strange.

4) Pelagic tunicates of the South Pacific.

In addition to several appendicularians commonly occurring in the warm waters of the world oceans, LohmanN (1931) identified the following 15 species 
in the collection made by FRIEDRICH DAHL in 1896-97 at Ralum of the Bismarck Archipelago, approximately $4^{\circ} \mathrm{S} \times 152^{\circ} \mathrm{E}$.

O. gracilis

O. graciloides

O. parva

O. mediterranea

$P$. verticalis

P. gracilis

Alth tumida

Frit. fraudax

Frit. gracilis

Frit. borealis f. intermedia (described as Frit. messanensis by LOHMANN)

Frit.borealis f. sargassi (described as Frit.borealis truncata by LOHMANN)

Frit. tenella

Frit. venusta (described as Frit. bicornis by LoHMANN)

T. fertilis

App. sicula

GARSTANG and Georgeson (1935) recorded O. longicauda, O. rufescens, O. dioica and Steg. magnum (described as a new species Stegosoma conogaster) from the vicinity of Three Kings Islands of Northern New Zealand during the British Antarctic ("Terra Nova") Expedition, 1910. There, the first of the four species was the commonest and the last one was represented by 76 individuals, while the second and the third were quite scarce. Recently BARY (1960) studied the plankton samples collected by H.M.N.Z.S. Lachlau in south-eastern New Zealand waters stretching from $43^{\circ} 15^{\prime} \mathrm{S}$ to $51^{\circ} 41^{\prime} \mathrm{S}$ and published that $O$. fusiformis was captured by the hauls made mainly in cooler oceanic waters and $O$. dioica occurred infrequently in warm coastal waters. Lastly TokıokA (1960) records Frit. borealis f. sargassi, $O$. longicauda, $O$. dioica, $O$. fusiformis, O. parva and Steg. magnum from the lagoon water near Noumea, New Caledonia; these species are listed here in the order of abundance.

Of Thaliacea, Garstang (1933) recorded Dolioletta gegenbauri, Doliolum denticulatum and lesser individuals of Doliolina mülleri and Dolioletta mirabilis at the South Pacific stations during the British Antarctic Expedition and recently ThOMfson (1954) recorded Pyrosoma atlanticum and Iasis at the stations near Tasmania during the B.A.N.Z. Antarctic Research Expedition 1929-31 and also. Thetys and Salpa fusiformis in the area, these two species were considered by him to tolerate cooler conditions. Especially S. fusiformis appears to be most tolerant, of all salp species, of very cold water condition, its distribution being extended even to the pack ice area at $65^{\circ} \mathrm{S}$. BARY (1960) records abundant occurrences of Dolioletta valdiviae together with its old oozooids and Pyrosoma atlanticum in the area he studied. There, Ihlea magalhanica APSTEIN was very 
common, Salpa fusiformis f. aspera was common and Thalia democratica occurred abundantly though infrequently; besides, Pyrosoma spinosum, Iasis zonaria and Pegea confoederata were recorded. Thalia democratica is described in his paper without being divided into f. typica and var. orientalis. ToкIокA (1960) records Thalia democratica var. orientalis and Dolioletta gegenbauri var. tritonis in the south-western coastal waters of New Caledonia.

5) Pelagic tunicates of the Indian Ocean (Appendix Table 14, Tables 26-27).

The appendicularian fauna of the Indian Ocean has not yet been studied so fully as to be exactly compared with those of the Atlantic and some parts of the Pacific. First the fauna of the Indian Ocean was introduced to us by the "Deutsche Südpolar-Expedition" and the "Tiefsee-Expedition". In addition to the species listed in the column of CI of Table 1, Chunopleura microgaster LoHMANN $1914 \mathrm{a}$ and Frit. venusta (recorded as F. bicornis) were captured by the last Expedition near Sumatra. Generally speaking, appendicularians were very abundant in the northern tropical part of the Indian Ocean, especially they were found in very dense populations along the equatorial East African coast and at the entrance to Aden Bay under the special condition effected by monsoon; while they were extremely scarce in the southern part of the Indian Ocean (LoHMANN 1933, p. 176), although some warm water appendicularian population consisting of $O$. longicauda, $O$. fusiformis and Frit. borealis f. sargassi was found extending to the "Tiefsee-Expedition" Station $43^{\circ} 44^{\prime} \mathrm{S} \times 75^{\circ} 33.7^{\prime} \mathrm{E}$ where the water temperature was only $8.8^{\circ} \mathrm{C}$. Numbers of individuals caught in the southern Indian Ocean during the "Südpolar-Expedition" (p. 204) were :

\begin{tabular}{|c|c|c|}
\hline O. longicauda & 315 & Frit. haplostoma \\
\hline Steg. magnum & 246 & Frit. tenella \\
\hline O. fusiformis & 58 & Frit. pellucida \\
\hline O. cophocerca & 22 & Frit. formica.. \\
\hline O. albicans & 11 & O. parva \\
\hline O. rufescens.. & 9 & \\
\hline
\end{tabular}

The occurrence of $O$. fusiformis f. cornutogastra along the Somalian coast and at Poat Natal is considered to be noted. Later, Sewell (1953) recorded a single individual of each of Frit. pellucida and Frit. formica and several specimens of $O$. dioica and $O$. rufescens from Sta. $58\left(22^{\circ} 22^{\prime} 12^{\prime \prime} \mathrm{N} \times 59^{\circ} 57^{\prime} 30^{\prime \prime} \mathrm{E}\right)$ in the Arabian Sea region, where "enormous numbers of Noctiluca were swarming in the surface water". It is noteworthy that none of O. longicauda nor O. fusiformis occurred there. ToкіокA (1956 a) shows the occurrence of 23 forms in the central part of the Indian Ocean (Table 1, CI). The commonest species was O. longicauda and next O. fusiformis. O. rufescens and Steg. magnum occurred abundantly, too. $O$. cophocerca and Frit. borealis f. sargassi were met with frequently, but less than the preceding four species. In addition to them, $O$. albicans, O. parva, O. dioica, Frit. pellucida, Frit. haplostoma and Frit. formica f. 
digitata occurred in significant numbers. The remarkable scarcity of $M$. huxleyi is rather strange when it is compared with the abundance of Steg. magnum in this region. F/L was less than 1.00 in all 26 samples. The same author ( $1955 \mathrm{~b})$ found 12 species in the collections made in the North Eastern part of the Ocean (Nicobar, Nias and Bali-Lombok). These include the first six of abundant species in the central part; besides, $O$. gracilis, M. huxleyi, Frit. haplostoma, Frit. formica, Frit. pellucida and Frit. venusta. The last one was not included in the collection from the central part.

In Lawson's Bay near Waltair, East India, according to Ganapati and Bhavanarayama (1958), $O$. longicauda, $O$. fusiformis and $O$. dioica are found throughout the year and considered to be able to tolerate wide ranges of salinity and temperature. Frit. lucibila (=Frit. haplostoma), Frit. campila

\begin{tabular}{|c|c|c|}
\hline 0.00 & 5 & \multirow{4}{*}{26} \\
\hline$<0.10$ & 3 & \\
\hline $0.11-0.50$ & 12 & \\
\hline $0.51-1.00$ & 6 & \\
\hline$>1.01$ & 0 & 0 \\
\hline $\begin{array}{l}\text { Number of } \\
\text { samples }\end{array}$ & & \\
\hline
\end{tabular}

Table 26. $\mathrm{F} / \mathrm{L}$ in the central part of the Indian Ocean (ToKIoKA 1956a). (= probably haplostoma with a slightly wider tail musculature), Frit. formica, $O$. cophocerca and some salps (Pegea, Ritteriella amboinensis, Cyclosalpa pinnata and Salpa cylindrica) are found in the southerly current, characterized by low salinity, high turbidity and high temperature, during July $\sim$ December, while Frit. haplostoma, Frit. limpida (=haplostoma), Frit. pellucida, Frit. borealis f. sargassi, $O$. rufescens and Althoffia pacifica (=probably Pelagopleura gracilis) occur in the northerly current, characterized by high salinity, high transparency and low temperature, during January June. In addition to these, "in the March $\sim$ April period, there is upwelling in the nearshore waters and the mesopelagic Frit. pellucida makes its appearance in the surface waters during these months". It is rather difficult to find out differences of any essential significance between the community including Frit. haplostoma, Frit. formica, $O$. cophocerca and some salps and that containing Frit. haplostoma, Frit. pellucida, Frit. borealis f. sargassi, $O$. rufescens and Pelagopleura. But this seems to show that the composition of far offshore appendicularian populations may differ considerably from time to time and that Frit. haplostoma occurs rather commonly in this region. As fragmental records, Ока (1915) identified Megalocercus sp. (most probably M. huxleyi) together with salpas, Iasis, Metcalfina, Salpa cylindrica, Thetys and Pegea, in the collection of the Indian Museum.

On the west coast of Australia, Lohmann (1909a) examined nine plankton samples collected in or near Sharks Bay. In six hauls made in the Bay only $O$. dioica was found, while in three others collected near Fremantle outside the Bay $O$. longicauda, $O$. fusiformis, $O$. rufescens and $O$. cophocerca occurred in addition to $O$. dioica; proportions of these five species are given below in Table 27. $\mathrm{F} / \mathrm{L}$ was $0.05-0.09$ in these hauls. In addition to the above-mentioned five oiko- 
pleurids, a single specimen of Fritillaria abjornseni was found at North Fremantle in the Swan River (sea water) and three individuals of Doliolum denticulatum occurred in the hauls made in Sharks Bay.

Of Thaliacea, besides the previously made records by Sewell (1926) and others, SEwelL (1953) records that Thalia was the commonest of all salpas and Doliolum denticulatum and Dolioletta gegenbauri occurred abundantly in the surveyed Arabian Sea region during the John Murray Expedition 1933-34; here Doliolum nationalis was included in the former and Dolioletta gegenbauri var. tritonis was treated under the latter species. He mentions that Thalia democratica var. orientalis occurred in the area, too and there it seemed to be more abundant in the greater depths than in the surface water at least at Station 61. My examination on the collection from the central part of this ocean revealed that Doliolum nationalis occurred in the collection, but none of Doliolum denticulatum (Appendix

\begin{tabular}{|l|c|c|}
\cline { 2 - 3 } \multicolumn{1}{c|}{} & Station 24 & $\begin{array}{c}\text { Stations 28 and 28a } \\
\text { near the Bay }\end{array}$ \\
\hline O. longicauda & $89.5 \%$ & $43.5 \%$ \\
\hline O. fusiformis & 8.5 & 2.0 \\
\hline O. dioica & 0.25 & 38.5 \\
\hline O. rufescens & 1.5 & 16.0 \\
\hline O. cophocerca & 0.25 & - \\
\hline Number of individuals & 348 & 169 \\
\hline
\end{tabular}

Table 27. Proportions of five speciess of appendicularians occurred near Sharks Bay. (LoHMANN 1909a)

Table 14). According to the results of the "Tiefsee-Expedition" by the "Valdivia" (Neumann 1906), Doliolum denticulatum was found widely distributed in the warmwater regions of the Indian Ocean, while Doliolum nationalis occurred in the Gulf of Bengal, in the waters along Sumatra and the eastern coast of Africa extending from Aden to Cape Town; besides, the occurrences near the Seychells and St. Paul Island were recorded, the occurrence at the latter locality must be noted as it is located near the middle of the southern Indian Ocean far apart from the coastal waters. The distributions of Dolioletta gegenbauri and its variety tritonis seemed to conform roughly to that of Doliolum nationalis, although the distribution of the first form was extended to the area beyond Madagascar and to New Amsterdam. In the Red Sea, are recorded the occurrence of Doliolum denticulatum, Doliolum nationalis and Doliolina intermedia. The most important salps collected during the expedition of the "Investigator" 1922-23 were Thalia democratica, Salpa cylindrica and Iasis zonaria (SEwELL 1926, p. 117). 


\section{PELAGIC TUNICATES OF THE ATLANTIC}

(a) The Atlantic Ocean. Appendicularians:-The first report on the appendicularian fauna of the warm water regions of the Atlantic was given by LANGERHANS (1880) who recorded nine species from the waters surrounding the Madeiras, they were $O$. longicauda (described as $O$. velifera), $O$. fusiformis, $O$. dioica, $O$. rufescens, Steg. magnum (described as Oikopleura magna), Frit. formica, Frit. pellucida (listed as Frit. furcata), Frit. megachile and App. sicula. The fauna of the North Atlantic was then clarified by LoHmann's comprehensive studies (1896 b) based on the material of the Plankton Expedition. This time were identified the 25 species shown in Table 28. Then the collections of the "Tiefsee-Expedition" (1898) and the "Deutsche Südpolar-Expedition" (1901-03) were examined by the same author and others and the following eleven species: O. graciloides, $O$. fusiformis f. cornutogastra, $M$. abyssorum (described by LoHMANN as $M$. atlanticus Lohmann 1914), P. verticalis, P. oppressa (Lomann) 1914, P. gracilis, Bathochordaeus charon, Frit. helenae Lohmann 1924, Frit. drygalski Lohmann 1924, Frit. borealis f. intermedia (described by LoHMANN as Frit. messanensis) and Frit. scillae were added to the warm water appendicularian fauna of the Atlantic. The occurrence of Frit. megachile in the Madeiras waters was doubted by LOHMANN, as the specimen described by Langerhans resembled LoHManN's Frit. tenella. Recently, however, this species was reported again from the South Atlantic by BJönnerg \& FoRNERIS (1955) who recorded 15 species of appendicularians from the surrounding waters of Trinidad Island $\left(20^{\circ} 30^{\prime} \mathrm{S} \times 29^{\circ} 22^{\prime} \mathrm{W}\right)$ and Jaseur Bank $\left(20^{\circ} 40^{\prime}\right.$ $\left.\mathrm{S} \times 35^{\circ} 10^{\prime} \mathrm{W}\right)$, this includes the new record of Frit. abjornseni in the Atlantic. BERNARD (1958) expresses her opinion that Frit. drygalski might be identical with Frit. aequatorialis (p. 216). Treating this as a distinct one, in all 38 forms of appendicularians are known from the warm waters of the Atlantic.

In the warm water regions of the Atlantic, appendicularians are most abundant in the equatorial region and the starting area of the North Equatorial Current along the western African coast near the Cape Verde Islands and the wide area along the Brazilian coast near the estuary of the Amazon. On the other hand, in the West Wind Drift in the north-eastern part of the North Atlantic, appendicularians are very poor both in number of individuals and number of occurring species.

$O$. longicauda is the commonest species throughout the warm water regions of the Atlantic. Next $O$. fusiformis which is also distributed widely, O. rufescens and $O$. cophocerca occur abundantly, especially in the far offshore waters, and may take the place of $O$. fusiformis in some areas such as the western half of the Sargasso Sea, the northern part of the starting area of the North Equatorial Current and the Benguela Stream. Frequent and abundant occurrence of $O$. dioica is a remarkable feature characteristic of the waters near the coast and also the currents strongly influenced by the coastal water as in the Guinea Current. The 


\begin{tabular}{|l|r|r|r|r|r|r|r|r|}
\hline \multicolumn{1}{c|}{ A } & $\begin{array}{c}\text { Florida } \\
\text { Current }\end{array}$ & $\begin{array}{c}\text { Sargasso } \\
\text { Sea }\end{array}$ & $\begin{array}{c}\text { North } \\
\text { Equa. } \\
\text { Current }\end{array}$ & $\begin{array}{c}\text { Guinea } \\
\text { Current }\end{array}$ & $\begin{array}{c}\text { South } \\
\text { Equa. } \\
\text { Current } \\
\text { (Mix. Ar. }\end{array}$ & $\begin{array}{c}\text { South } \\
\text { Equa. } \\
\text { Current }\end{array}$ & $\begin{array}{c}\text { West- } \\
\text { wind } \\
\text { Drift }\end{array}$ & Sum \\
\hline O. longicauda & $* 1120$ & $* 2726$ & 4700 & 4900 & $* 3510$ & $* 5518$ & $* 2500$ & 24974 \\
\hline O. intermedia & $*$ & $* 117$ & 297 & 38 & 30 & - & 13 & 495 \\
\hline O. fusiformis & 140 & 528 & 1000 & 1232 & 720 & 855 & 300 & 4775 \\
\hline O. gracilis & - & 38 & - & - & - & - & - & 38 \\
\hline O. cophocerca & $* 560$ & $* 1675$ & 913 & 825 & $* 770$ & $* 158$ & 3800 & 8701 \\
\hline O. albicans & - & $* 45.6$ & $*$ & $* 50$ & $* 39$ & $*$ & $*$ & 135 \\
\hline O. parva & $*$ & $* 153$ & - & 143 & - & - & - & 296 \\
\hline O. rufescens & 180 & 1170 & 2380 & 1210 & $* 792$ & $* 568$ & 413 & 6713 \\
\hline O. dioica & - & $* * 351$ & 637 & 1437 & 80 & 163 & 25 & 2693 \\
\hline
\end{tabular}

\begin{tabular}{|c|c|c|c|c|c|c|c|c|}
\hline $\mathbf{B}$ & \multicolumn{7}{|c|}{ Frequency of Occurrence } & Mean \\
\hline Steg. magnum & 20 & 82 & 50 & 75 & 60 & 32 & 50 & 53 \\
\hline Folia gracilis & - & - & - & 38 & 10 & - & - & 7 \\
\hline Alth. tumida & 20 & 27 & - & - & 20 & - & - & 10 \\
\hline T. fertilis & 20 & 18 & 33 & 13 & - & - & - & 12 \\
\hline Frit. gracilis & - & 27 & - & 38 & 10 & 11 & - & 12 \\
\hline Frit. pellucida & 40 & 58 & 83 & 38 & 40 & 32 & 50 & 49 \\
\hline Frit. fraudax & - & 18 & - & - & - & - & - & 3 \\
\hline Frit. aberrans & - & - & - & - & 10 & - & - & 1 \\
\hline Frit. haplostoma & 20 & 30 & 67 & 50 & - & 32 & - & 28 \\
\hline Frit. formica & 40 & 82 & 67 & 88 & 50 & 63 & 50 & 63 \\
\hline Frit. aequatorialis & - & - & - & - & 20 & 16 & - & 5 \\
\hline Frit. tenella & 20 & 27 & 33 & 38 & 10 & 16 & - & 21 \\
\hline Frit. venusta & 40 & 6 & 50 & 63 & 50 & 11 & - & 31 \\
\hline $\begin{array}{l}\text { Frit. borealis } \\
\text { f. sargassi }\end{array}$ & 40 & 42 & 67 & 63 & 40 & 42 & 25 & 46 \\
\hline App. sicula & 20 & 70 & 67 & 88 & 60 & 63 & 50 & 60 \\
\hline K. tenuis & - & 15 & 17 & - & - & - & - & 5 \\
\hline $\begin{array}{c}\text { Nomber of } \\
\text { samples }\end{array}$ & 5 & 33 & 6 & 8 & 10 & 19 & 4 & \\
\hline
\end{tabular}

Table 28. Abundance of warm water-oikopleurids, Frequency of Occurrence $\times$ Mean Percentage, in respective currents and seas during the Plankton Expedition (A), and Frequency of Occurrence of other appendicularians in the same areas (B). * *..excluding the occurrences not shown in numbers, ***including the $100 \%$ occurrence at St. George Harbour, Bermuda on August 10. Equa...Equatorial, Mix. Ar...Mixing area. 


\section{$\mathbf{C}$}

\begin{tabular}{|l|c|}
\hline O. longicauda & $77.5 \%$ \\
\hline O. intermedia & 1.0 \\
\hline O. fusiformis & 3.5 \\
\hline O. rufescens & 1.0 \\
\hline O. cophocerca & 4.0 \\
\hline O. albicans & 7.0 \\
\hline
\end{tabular}

Table 28 (C). Percentage composition of the appendicularian-population in the Benguela Stream in the range between Ascension and Cape Town 1901-1903.

(LOHMANN \& BUCKMANN 1926, pp. 196-197)

distribution of F/L during the Plankton Expedition seems to show the trend towards the slight increase in the equatorial region (Table 29). BJöNBERG and Forneris (1956 a) show a very interesting F/L distribution around Fernando de Noronha Island. Values of $\mathrm{F} / \mathrm{L}$ were generally higher at the stations located on the northern side of the island than at the south side stations, although it is difficult to judge whether or not the above distribution of $F / L$ values is attributable to different water masses flowing along respective sides of the island. In the North Atlantic, the dominancy of $O$. longicauda becomes indistinct with the fall of the water temperature, contrarily percentages of $O$. fusiformis, $O$. cophocerca and $O$. albicans are raised till $O$. longicauda disappears at last and the dominancy is taken by $O$. fusiformis which may reach near Greenland (Lohmann $1896 \mathrm{a}$ ). In a sample collected at the station of Aug. 2a in the mixing area between the warm Florida Current and the cold Labrador Current during the Plankton Expedition, many $O$. dioica and some $O$. parva and $O$. albicans were found in addition to cold water species O. labradoriensis and Frit. borealis f. typica, but none of O. longicauda was found. The distribution of $O$. fusiformis is very wide near the equatorial region and in the northern area beyond the region, but it seems to be narrowed in the South Atlantic south of ca. $10^{\circ} \mathrm{S}$, there the distribution is seen along the continents, although the edge of the dense distribution attains $50^{\circ} \mathrm{S}$; while the southern limit of dense occurrences of $O$. longicauda is seen along the isotherm of $18^{\circ} \mathrm{C}$ and the distribution seems to be limited by the $15^{\circ} \mathrm{C}$ isotherm (LoHManN \& HentSchel 1939). Udvardy (1958) records that $O$. longicauda occurred during the Swedish Antarctic Expedition 1901-03 most commonly between $38^{\circ} 50^{\prime} \mathrm{N}-$ $43^{\circ} 52^{\prime} \mathrm{S}$ and its dense population was observed at $51^{\circ} 14^{\prime} \mathrm{S}$, while $O$. fusiformis was found between $35^{\circ} 5^{\prime} \mathrm{N}-61^{\circ} 29^{\prime} \mathrm{S}$. These seem to approve that $O$. fusiformis is more tolerant against the lowered water temperature than O. longicauda. Then, 
it is very strange that $O$. longicauda had been found in the Antarctic Sea, reaching $72^{\circ} 30^{\prime} \mathrm{S}$, while $O$. fusiformis had never been collected in the Antarctic (LoHmann 1928). Of fritillarians, Frit. formica, Frit. pellucida and Frit. borealis f. sargassi are the commonent species, Frit. formica occurred most frequently during the Plankton Expedition, but Frit. borealis (chiefly f. sargassi) was the most abundant of all fritillarians and at the same time of all appendicularians in the $50-0 \mathrm{~m}$ plankton samples collected near Fernando de Noronha Island (ca. $3^{\circ} 41^{\prime} \mathrm{S} \times$

\begin{tabular}{|c|c|c|c|c|c|c|c|c|c|c|c|c|c|c|}
\hline A & \multicolumn{2}{|c|}{$\begin{array}{l}\text { Florida } \\
\text { Current }\end{array}$} & \multicolumn{2}{|c|}{$\begin{array}{c}\text { Sargasso } \\
\text { Sea }\end{array}$} & \multicolumn{2}{|c|}{$\begin{array}{c}\text { North } \\
\text { Equatorial } \\
\text { Current }\end{array}$} & \multicolumn{2}{|c|}{$\begin{array}{l}\text { Guinea } \\
\text { Current }\end{array}$} & \multicolumn{2}{|c|}{$\begin{array}{c}\text { South } \\
\text { Equatorial } \\
\text { Mixing Area }\end{array}$} & \multicolumn{2}{|c|}{$\begin{array}{c}\text { South } \\
\text { Equatorial } \\
\text { Current }\end{array}$} & \multicolumn{2}{|c|}{$\begin{array}{l}\text { West } \\
\text { Wind } \\
\text { Drift }\end{array}$} \\
\hline $\begin{array}{c}\text { Number of } \\
\text { samples }\end{array}$ & \multicolumn{2}{|c|}{5} & \multicolumn{2}{|c|}{33} & \multicolumn{2}{|c|}{6} & \multicolumn{2}{|c|}{8} & \multicolumn{2}{|c|}{10} & \multicolumn{2}{|c|}{19} & \multicolumn{2}{|c|}{4} \\
\hline $0 / 0$ & \multicolumn{2}{|c|}{1} & \multicolumn{2}{|c|}{3} & \multicolumn{2}{|c|}{-} & \multicolumn{2}{|c|}{ - } & \multicolumn{2}{|c|}{ - } & \multicolumn{2}{|c|}{1} & \multicolumn{2}{|c|}{ - } \\
\hline $\mathrm{v} / \mathrm{v}$ & \multicolumn{2}{|c|}{ 一 } & \multicolumn{2}{|c|}{2} & \multicolumn{2}{|c|}{$\rightarrow$} & \multicolumn{2}{|c|}{ - } & \multicolumn{2}{|c|}{2} & \multicolumn{2}{|c|}{3} & \multicolumn{2}{|c|}{1} \\
\hline 0.00 & 3 & \multirow{2}{*}{3} & 15 & \multirow{2}{*}{18} & - & \multirow{2}{*}{2} & 1 & \multirow{2}{*}{1} & 2 & \multirow{2}{*}{3} & - & \multirow{2}{*}{5} & 1 & \multirow{2}{*}{2} \\
\hline$<0.10$ & - & & 3 & & 2 & & - & & 1 & & 5 & & 1 & \\
\hline $0.11-0.50$ & 1 & \multirow{2}{*}{1} & 8 & \multirow{2}{*}{10} & 3 & & 7 & & 3 & & 8 & & - & \\
\hline $0.51-1.00$ & - & & 2 & & 1 & & - & & 1 & & 1 & & 1 & \\
\hline$\infty$ & & & & & & - & & & & & & 1 & & \\
\hline
\end{tabular}

\begin{tabular}{|c|c|c|c|c|}
\hline $\mathbf{B}$ & $\begin{array}{r}\text { Nort } \\
\text { the }\end{array}$ & & Sou & e of \\
\hline $\begin{array}{c}\text { Number of } \\
\text { stations }\end{array}$ & & & & \\
\hline $\begin{array}{c}\text { Number of } \\
\text { samples }\end{array}$ & \multicolumn{2}{|c|}{. } & \multicolumn{2}{|c|}{12} \\
\hline$<0.10$ & 1 & \multirow{3}{*}{1} & - & \multirow{3}{*}{12} \\
\hline $0.11-0.50$ & - & & 7 & \\
\hline $0.51-1.00$ & - & & 5 & \\
\hline $1.01-2.00$ & 4 & 4 & - & 0 \\
\hline
\end{tabular}

\begin{tabular}{|c|c|c|}
\hline 0.00 & 2 & \multirow{4}{*}{8} \\
\hline$<0.10$ & 1 & \\
\hline $0.11-0.50$ & 3 & \\
\hline $0.51-1.00$ & 2 & \\
\hline $1.01-2.00$ & 1 & 1 \\
\hline $\begin{array}{c}\text { Number of } \\
\text { samples }\end{array}$ & \multicolumn{2}{|c|}{9} \\
\hline
\end{tabular}

Table 29. Occurrences of respective values of $\mathrm{F} / \mathrm{L}$ in the Atlantic. A $\cdots$ In the collection of

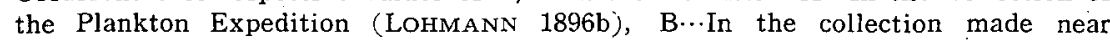
Fernando de Noronha Island, the maximum value 1.87 (BJórnBerg \& Forneris 1956a); C...IIn the collection made near Alcatrazes Island, the maximum value 1.43. (BJÖRNBERG \& FORNERIS 1956b)

$32^{\circ} 25^{\prime} \mathrm{W}$ ) in the South Equatorial Current and Frit. pellucida was the next one (BJöRnBerg \& Forneris 1956 a) and Frit. pellucida was the most significant fritillarian in the collection made near Alcatrazes Island located approximately at $24^{\circ} \mathrm{S} \times 46^{\circ} \mathrm{W}$ (BJörnBERG \& ForNERIS $1956 \mathrm{~b}$ ).

Frit. haplostoma usually occurs sparsely in the far offshore waters of the Atlantic, although it was found occurring in swarms at some coastal stations such 
as the station of Oct. 9 during the Plankton Expeditipn not far from the Tocantin Delta near the estuary of the Amazon (LOHMANN $1896 \mathrm{~b}$ ) and at St. 10, an inshore station in the surrounding waters of Alcatrazes Island (BJöRnBERg \& ForNeris 1956 b). Results of the German Atlantic Expedition by the "Meteor" 1925-27 show also that pretty abundant occurrences of this species were observed along the eastern coast of South America, in the range between La Plata and Rio and off Cape S. Roque, and near the estuary of the Niger (Lohmann \& Hentschel 1939).

Appendicularian faunas of the Baltic Sea and the North Sea are represented by $O$. dioica and Frit. borealis; that of the latter sea is enriched by frequent visiting of $O$. fusiformis and $O$. labradoriensis; besides, there are records of rare occurrences of $O$. vanhöffeni, Frit. venusta and App. sicula (BückMANN 1926, also BERRILL 1950). Frit. borealis is mostly represented by f. typica, although f. intermedia can be seen sometimes.

In the inlet waters or the very coastal water in the warm water regions of the Atlantic, $O$. dioia and $O$. longicauda are common inhabitants, they were ever found even in the somewhat brackish water near the Tocantin Delta, especially $O$. dioica was found in the Rio Tocantin upper than Para during the Plankton Expedition.

Thaliaceans:--Many papers have been published on the Atlantic salps and it is a well-known fact that Thalia democratica is the commonest one in the warm water regions, although the distinction between the typical and orientalis forms have never been made and consequently the occurrence of var. orientalis in the Atlantic can not yet be recognized.

During the Plankton Expedition, Doliolum denticulatum was distributed very widely in the warm water regions, although its distributional area seemed to be narrower than that of Doliolum nationalis in the north-eastern part of the North Atlantic (BORGERT 1894). The distribution of Doliolum nationalis is, however, considered to show the trend towards the increase in the inshore waters, for instance during the Plankton Expedition this doliolum occurred infrequently at offshore stations in the Florida Current, Sargasso Sea and North Equatorial Current, but was collected abundantly near the Cape Verde Islands and at most stations in the North Equatorial Current, Guinea Current and South Equatorial Current located in the range between Cape Verde and Ascension, excepting only a single station. It was very scarce again at offshore stations in the South Equatorial Current, located in the range between Ascension and Fernando de Noronha, but it occurred at every station in the same current in the range between Fernando de Noronha and the estuary of the Rio Para. Also it was found in large numbers at the station of Oct. 30 off Spain and near the western end of the English Channel and the entrance to the Mediterranean Sea. Occurrences of Doliolum nationalis off Plymouth are reported also by RUSSELL and HASTINGS (1933). 
In the South Atlantic, Doliolum denticulatum occurs steadily in the waters off the west coast of Africa extending from the equatorial zone to the Benguela Current, but Doliolum nationalis had been found occurring abundantly only in the equatorial zone, stopping suddenly and completely when the cool waters of the Benguela Stream were encountered (Neumans 1906). Doliolum nationalis was not found in the Benguela Stream during the German Atlantic Expedition by the "Meteor", either (KRÜGER 1939). Recently, however, ZYL (1960) records the occurrence of this species in the routine area in the Benguela Stream off South Africa and on many occasions in association with Doliolum denticulatum. There, Doliolum denticulatum and many salps show their highest frequencies of occurrences in the spring summer season, but Doliolum nationalis solely has its highest incidence during winter. Furthermore these is a direct relationship between the mean integral temperature of the water of the $0-50 \mathrm{~m}$ layer and the occurrences of many salps and Doliolum denticulatum in quantities, but the relation between the former and the dense occurrence of Doliolum nationalis is inverse. Thus the distribution of Doliolum denticulatum and that of Doliolum nationalis show the tendency of having inverse relations in the Atlantic. The "Tiefsee-Expedition" caught some Doliolum denticulatum and Doliolum nationalis near Cape Town (Neumann 1906), these were very probably carried there by the Agulhas Current.

The distribution of Dolioletta gegenbauri var. tritonis seems to resemble somewhat that of Doliolum nationalis, although it extends more northerly than that of Doliolum nationalis. During the Plankton Expedition, this doliolum occurred most abundantly in the eastern parts of the North Equatorial, Guinea and South Equatorial Currents, stretching between the Cape Verde Islands and Ascension and also in the western part of the South Equatorial Current between Fernando de Noronha Island and the estuary of the Rio Para. In addition, it occurred near the boundary between the Florida Stream and the Sargasso Sea and was found carried north by the Gulf Stream to New Foundland in west and to the Hebrides in east (BORGERT 1894). In the southern South Atlantic it occurs around the Cape of Good Hope and in the Benguela Gurrent where it is found most frequently in spring - summer, though rather rare $\left(Z_{Y L} 1960\right)$. Dolioletta gegenbauri is recorded from the waters near the Shetlands, Faeroes and Scottish waters (Fraser 1949) and also from the North Sea and occasionally from the western portion of the English Channel (Russell and Hastings 1933); most specimens belong to the typical form, but a small part is represented by var. tritonis. It occurs more abundantly in the Mediterranean Sea than in the Sargasso Sea.

Doliolina intermedia reaches northerly $63,3^{\circ} \mathrm{N}$ in the northern mixing area, but its abundant occurrence seems to be confined to the subtropical zone of the South Atlantic, south of $15^{\circ} \mathrm{S}$ in the eastern and of $30^{\circ} \mathrm{S}$ in the western part of the ocean, namely the distribution is limited northerly by the line of the tropical convergence (KRUGER 1939). 
(b) The Mediterranean Sea. Fol $(1872,1874)$ recorded the following twelve appendicularians from the waters around Messiana:
O. longicauda (described as $O$. spissa)
O. fusiformis
O. dioica
O. rufescens
O. cophocerca
Frit. haplostoma (described as Frit. aplostoma)
Frit. formica
Frit. urticans
Frit. pellucida (described as Frit. furcata)
Frit. megachile
App. sicula
K. tenuis

The appendicularian fauna at Messina, however, had grown up to be 28 species when LoHmanN listed them in $1909 \mathrm{~b}$.
o. longicauda
Frit. formica
O. intermedia
Frit. fraudax
O. fusiformis
Frit. gracilis
O. gracilis
Frit. aequatorialis
O. dioica
Frit. urticans
O. rufescens
Frit. pellucida
O. parva
Frit. borealis
o. mediterranea Lohmann 1899
Frit. messanensis
O. cophocerca
Frit. megachile
O. albicans
Frit. tenella
M. abyssorum
Frit. venusta
Steg. magnum
App. sicula
Folia gracilis
$K$. tenuis
Frit. haplostoma
K. mossi Herdman

Of these species, Frit. borealis probably means Frit. borealis f. intermedia and partly f. sargassi, Frit. messanensis is considered to be identical with Frit. borealis $\mathrm{f}$. intermedia as mentioned already on P. 363 and $K$. mossi may be treated as a synonym of $K$. tenuis. In addition to the above 27 forms, O. graciloides, Frit. charybdae, Frit. scillae LoHmann 1898 and K. oceanica LoHMANN 1899 had been known from the neighbouring waters of Messina. Thus, the fauna have increased to 31 forms; among these O. longicauda, O. cophocerca, Frit. pellucida and Frit. borealis are remarkable. In 1913, UEBEL reported $O$. najadis from the Adriatic Sea, but this is considered to be a form of $O$. parva, having a comparatively wider tail musculature. Frit. formica described from the Mediterranean Sea was 
represented by f. tuberculata which was defined by LoHMANN \& BückMANN (1926).

VERNIÈrEs (1933) reports eleven appendicularians from Banyuls, six from Sète and fifteen from Villefranche (1933 and 34). His Fritillaria borealis acuta $\mathrm{f}$. typica var. mediterranea from Banyuls may be treated as belonging to Frit. borealis f. intermedia as mentioned already on page 363 and his Frit. borealis troncata elongata from Villefranche may be considered to be included also in Frit. borealis $\mathrm{f}$.

\begin{tabular}{|c|c|c|c|}
\hline & Banyuls & Sète & Villefranche \\
\hline O. longicauda & + & + & + \\
\hline o. intermedia & - & - & + \\
\hline o. fusiformis & + & + & + \\
\hline o. dioica & + & + & + \\
\hline o. parva & + & - & - \\
\hline O. cophocerca & + & - & + \\
\hline O. albicans & + & + & + \\
\hline Steg. magnum & - & - & + \\
\hline $\begin{array}{l}\text { Pelagopleura } \\
\text { haranti }\end{array}$ & - & - & + \\
\hline Frit. haplostoma & + & - & - \\
\hline Frit. formica & + & + & + \\
\hline Frit. gracilis & - & - & + \\
\hline Frit. pellucida & + & + & + \\
\hline $\begin{array}{l}\text { Frit. borealis } \\
\text { f. intermedia }\end{array}$ & + & - & + \\
\hline Frit. megachile & - & - & + \\
\hline Frit. scillae & - & - & + \\
\hline T. fertilis & - & - & + \\
\hline K. tenuis & + & - & + \\
\hline
\end{tabular}

Table 30. Occurrences of appendicularians along the Mediterranean coast of France.

intermedia. O. longicauda was the commonest species, $O$. fusiformis and Frit. pellucida were also common and $O$. dioica, Frit. formica and Frit. borealis f. intermedia were pretty abundant, while $O$. cophocerca and Frit. haplostoma were rare in his collection from Banyuls. Frit. scillae is described as being common in the collection made at Villefranche. Doliolum denticulatum, Dolioletta gegenbauri and Thalia democratica also were found in VERNIEREs' collection from Villefranche. Recently Fenaux (1959a and b) reported six more appendicularians from Ville- 
franche, they are O. rufescens, M. abyssorum, Frit. haplostoma, Frit. fraudax, Frit. tenella and App. sicula; besides, Frit. borealis. Thus the appendidularian fauna of the waters near Villefranche is raised to 21 species. O. longicauda was the commonest form there, too; then followed $O$. dioica and $O$. fusiformis. Frit. pellucida, Frit. borealis and $O$. cophocerca also occurred in pretty large numbers. The occurrence of Thalia democratica in this area is also recorded (1959a, p. 7).

The occurrence of $M$. abyssorum was recorded by BERNARD (1954) from the waters off Alger. Later, the same author (1958) reports the occurrence of 21 appendicularians from the same waters; they are:

$\begin{array}{ll}\text { O. longicauda } & \text { Frit. formica f. tuberculata } \\ \text { O. intermedia } & \text { Frit. formica f. digitata } \\ \text { O. fusiformis } & \text { Frit. gracilis } \\ \text { O. dioica } & \text { Frit. fraudax } \\ \text { O. rufescens } & \text { Frit. aequatorialis } . \\ \text { O. parva } & \text { Frit. pellucida } \\ \text { O. cophocerca } & \text { Frit. borealis f. intermedia } \\ \text { O. albicans } & \text { Frit. borealis f. sargassi } \\ \text { M. abyssorum } & \text { Frit. venusta } \\ \text { Steg. magnum } & \text { App. sicula } \\ \text { P. haranti } & \end{array}$

Frit. borealis $\mathrm{f}$. intermedia is described in her paper as Frit. borealis var. mediterranea and Frit. borealis $\mathrm{f}$. sargassi is shown as f. crassa. There, O. longicauda is the commonest species, next $O$. dioica and then followed by $O$. intermedia, $O$. albicans and $O$. cophocerca in the order of abundance. $O$. fusiformis is the most scarce one among the species of Oikopleura. Of fritillarians, Frit. pellucida is the commonest one and followed by Frit. formica and then by Frit. borealis f. sargassi. Besides these appendicularians, occurrences of Doliolum denticulatum, Doliolum nationalis and the typical and orientalis forms of Thalia democratica are recognized by her. FURNESTIN (1958) examined the plankton collection made in the Gibraltar Straits and the adjacent Alboran Sea and found that O. longicauda and $O$. dioica occurred there and $O$. longicauda was much more abundant than $O$. dioica. She records Thalia democratica from the surveyed area, but the distinction between the typical and orientalis forms is not made. Frit. formica is known from the vicinity of Gibraltar, too. In the neighbouring waters of the Balearic Islands, Doliolum denticulatum is recorded at Palma of Mallorca and MASsutI (1959) reports the common occurrence of Thalia democratica at Castellon, although the distinction between the typical and orientalis forms is not made. As to the doliolid fauna of the Mediterranean Sea, ULJANIN's monograph (1884) appeared in the series of the "Fauna und Flora des Golfes von Neapel" cannot be put aside, in which Doliolum ehrenbergii (=denticulatum), D. gegenbauri n. sp., D. rarum 
and D. mulleri are given; BORGERT (1893) found Doliolum nationalis in the Mediterranean Sea and SIGL (1912) confirmed the occurrences of Doliolum denticulatum, Doliolum nationalis and Dolioletta gegenbauri in the collection made by the PolaExpedition 1890-1894 in the Adriatic Sea, these three species were, however, not found in the eastern waters of much higher salinity.

The appendicularian fauna of the Black Sea is represented by a single species O. dioica as shown for instance by Nikitin (1929), Dolgopolskaia (1940) and NEGREA \& others (1959).

Summing up above-mentioned listings, the total of appendicularian species occurring in the Mediterranean Sea attains 33, two of which, Frit. formica and Frit. borealis, are divided respectively into two forms. The close relationship found between Frit. charybdae and Frit. urticans and that betweeu Frit. tenella and Frit. scillae, however, must be studied crucially in the future. Throughout the Mediterranean Sea, $O$. longicauda is the dominant-most species and next $O$. dioica at various parts of the Sea. O. fusiformis may occur rather abundantly at some places (Banyuls, Sète and Villefranche), but may be very scarce at others (Bay of Alger, etc.). O. cophocerca occurs frequently in considerable numbers, but $O$. rufescens is always quite rare in this sea. Frit. pellucida is the commonest species of fritillarians and followed by Frit. formica or Frit. borealis, while Frit. haplostoma is rare throughout the sea. The appendicularian fauna of this sea resembles closely that of the Atlantic. However, the scarcity of $O$. rufescens and Frit. borealis $\mathrm{f}$. sargassi, the relative fewness of $O$. fusiformis and contrarily the existence of f. tuberculata of Frit. formica and relative abundance of $O$. dioica may be accepted as the characteristics of the appendicularian fauna of the Mediterranean Sea when the fauna is compared with that of the Atlantic; besides, the occurrence or absence of some special, not so common, species are noted as shown in Table 35.

(c) The Gulf of Mexico (Table 31). In order to be compared with the appendicularian fauna of the area surveyed by the Shellback Expedition, the fauna of the Gulf of Mexico is mentioned here separately. Throughout the works of LoHMANN (1896 b and 1916), Brooks \& Kellner (1908), Garstang (1937) and Tokioka \& SUÀREZ (1956), twenty-three species of appendicularians are known from the Gulf. Namely the following eight species are known in addition to the 15 species listed in Table 31.

O. intermedia ( $=$ O. tortugensis BROOKS \& KELLNER 1908)

O. albicans

Alth. tumida

Bathochordaeus charon (=B. stygius GARSTANG 1937)

Frit. fraudax

Frit. tenella

App. sicula

K. tenuis 
In Cuban waters, $O$. longicauda is the commonest species and next $O$. dioica, being followed by $O$. rufescens and Frit. borealis f. sargassi. $O$. fusiformis and $O$. cophocerca are much less than O.rufescens; of fritillarians Frit. pellucida is the second predominant species, though much less than Frit. borealis f. sargassi. The relatively abundant occurrences of $O$.rufescens and the low population of $O$. fusiformis are common to the appendicularian fauna of Cuban waters and that of the Shellback area. However, the occurrences of much more abundant Frit. borealis $f$.

\begin{tabular}{|l|c|}
\hline \multicolumn{1}{|c|}{ Number of samples } & 47 \\
\hline O. longicauda & 5293 \\
\hline O. fusiformis & 304 \\
\hline O. fusiformis f. cornutogastra & 330 \\
\hline O. graciloides & 26 \\
\hline O. dioica & 1533 \\
\hline O. rufescens & 700 \\
\hline O. parva & 261 \\
\hline O. cophocerca & 207 \\
\hline Oikopleurids damaged & 527 \\
\hline Steg. magnum & 34 \\
\hline Frit. haplostoma & 24 \\
\hline Frit. formica f. digitata & 30 \\
\hline Frit. pellucida & 117 \\
\hline Frit. borealis f. intermedia & 26 \\
\hline Frit. borealis f. sargassi & 608 \\
\hline Frit. megachile & 10 \\
\hline & \\
\hline
\end{tabular}

Table 31. Abundance of respective appendicularians in Cuban waters shown in Frequency of Occurrence $\times$ Mean Percentage (calculated on the data given by TOKIOKA and SUÀREZ 1956).

sargassi and $O$. dioica and the relatively lower population of $O$. cophocerca in Cuban waters differ significantly from the constitution of appendicularian fauna of the Shellback area. The occurrences of $O$. fusiformis $f$. cornutogastra in a significant number may be considered as unique for the fauna of Cuban waters. All these aspects seem to show that the appendicularian fauna of the Gulf of Mexico and that of the Shellback area resemble each other as their constitutions are both included in the general type found in faunas of the tropical waters, but 
they do not show any further special relationship beyond this.

\section{GENERAL DISTRIBUTIONAL ASPECT OF PELAGIC TUNICATES IN THE NORTH PACIFIC}

(Tables 32-35)

1) Vertical distribution of appendicularians (Tables 32-33).

As most samples dealt with in the present paper were collected by vertical or oblique towing mostly from $50 \mathrm{~m}$ deep or from various depths beyond it, it is very important to examine first whether the centre of the appendicularian population is found in the surface layer shallower than $50 \mathrm{~m}$ or it is located more deeply. If the former is the case, then the trends deduced from comparing the data

\begin{tabular}{|c|c|c|c|c|}
\hline Water layers & \multicolumn{2}{|c|}{ in port } & \multicolumn{2}{|c|}{ in the strait } \\
\hline $0-1.5 \mathrm{~m}$ & 302 & \multirow{4}{*}{497} & 65 & \multirow{4}{*}{419} \\
\hline $1.5-10$ & 87 & & 109 & \\
\hline $10-30$ & 78 & & 123 & \\
\hline $30-60$ & 30 & & 122 & \\
\hline $60-100$ & - & & 62 & \\
\hline $100-150$ & - & - & 75 & 139 \\
\hline $150-200$ & - & - & 2 & \\
\hline
\end{tabular}

Table 32. Distribution of appendicularian population at Messina (LOHMANN 1933, Table on p. 177).

\begin{tabular}{|c|c|c|c|c|c|c|c|c|}
\hline Water layers in $\mathrm{m}$. & $0-50$ & $50-100$ & $100-200$ & $200-400$ & $400-600$ & $600-800$ & $800-1000$ & $900-1100$ \\
\hline Mean individuals & 579 & 170 & 86 & 8.5 & 2 & 2 & 0.7 & 1.5 \\
\hline $\begin{array}{l}\text { Percentages to the value } \\
\text { of } 0-50 \mathrm{~m} \text {. }\end{array}$ & 100 & 29.5 & 15 & 1.5 & 0.3 & 0.3 & 0.1 & 0.25 \\
\hline $\begin{array}{l}\text { The maximum value } \\
\text { observed }\end{array}$ & 6587 & 1560 & 631.5 & 74 & 46 & 10.25 & 6.5 & 5 \\
\hline $\begin{array}{l}\text { Frequency of occurrence } \\
\text { of } 0 \text {-value }\end{array}$ & 2.7 & 2.7 & 0 & 5 & 18 & 18 & 36 & 31 \\
\hline
\end{tabular}

Table 33. Number of appendicularian individuals per $50 \mathrm{~m}$. haul in respective water layers in the South Atlantic (Lohmamm \& Hentschel 1939, Table 40 on p. 190).

from samples from various depths one another may be accepted as general tendencies, while it would be quite unreasonable to compare the data from the shallower water samples with those from the deeper water samples if the latter were the case. It has been well known since LoHMANN's comprehensive studies (1896 b) on the appendicularian material of the Plankton Expedition that the important part of the appendicularian population lies in the upper $200 \mathrm{~m}$ layer, although 
some species auch as $O$. parva, Frit. tenella, Frit. megachile and Folia gracilis often penetrate into much deeper layers. Further, as to the distribution within the surface to $200 \mathrm{~m}$ layer, there are two available data, one is LoHManN's observation made at Messina and the other is the result of the "Meteor" Expedition in the South Atlantic. Although the densest population of appendicularians may be found in some cases in $100-200 \mathrm{~m}$ or $200-300 \mathrm{~m}$ layers as LOHMANN noted in the Sargasso Sea during the Plankton Expedition (1896 b) and in the Antarctic Sea during the "Deutsche Südpolar-Expedition" (1933, p. 178), the data given in Tables 32 and 33 seem to show that the most significant part of the appendicularian population is to be seen in the $0-50 \mathrm{~m}$ layer. On this general aspect of vertical distribution is based the comparison made in this paper between the data from samples collected by towing from various depths to the surface. As "in den obersten Wasserschichten im ganzen Warmwassergebiet Oikopleura longicauda VoGT und fusiformis Fol die herrschenden Arten sind" (LOHMANN 1933, p. 178), the distribution of $F / L$ should be recognized as one of the most important trends found in the appendicularian distribution. The appendicularian fauna of the superficial water seems to differ considerably from those of deeper layers. LOHMANN mentioned about the appendicularian population at Messina that the density in superficial layer is much lower in the warm season than in the cool season. Generally speaking, appendicularians were few in the superficial layer, and some species such as $O$. parva, Frit. tenella and Frit. megachile could be seen only in deeper layers beyond the $30-60 \mathrm{~m}$ layer at Messina. Also remarkable discrepancies were found in the constitution of the appendicularian population between the samples collected by surface towing and those collected by vertical hauling in the Japan Sea (Tables 13-15). All these seem to show evidently that the fauna of the superficial layer is to be treated as a special one. Furthermore, there may occur unusually dense populations of some species in the superficial layer as AIDA (1907) met with swarms of $K$. tenuis or O. rufescens at Misaki Harbour or I observed a spawning swarm of $O$. longicauda in Tanabe Bay and dense swarms of Frit. haplostoma in some Japanese inlet waters (Ток гока 1955 a). 2) Areas of abundant occurrences of appendicularians in the warm-water regions of the North Pacific. Results of the present studies seem to show that appendicularians occur densely in the North Pacific in the bedoti-water along the east coast of the old continent, in the Shellback area harbouring both Sagitta bedoti and Sagitta friderici and also in the equatorial zone where plankton organisms are much more abundant than in the adjacent tropical waters (JoHNson 1956 and KING \& HIDA 1957)*. This aspect resembles somewhat the distribution of dense population in the Atlantic. On the other hand, number of species and quantity

* Johnson, M. W. (1956): Some outlines of plankton concentration in the eastern and tropical Pacific. Proc. 8th Pacific Sci. Congr., Vol. 3, pp. 379-390, 6 text-figs.

KING, J. E. and HIDA, T. S. (1957): Zooplankton abundance in the central Pacific. Fish. Bull. U.S., No. 118, pp. 365-395. 
of individuals seem to be insignificant in the northeastern part of the Central North Pacific water mass, just as in the West Wind Drift in the North Atlantic. 3) Constitution of the appendicularian population (Tables 34 and 35).

Except for those in the neritic waters, the dense populations in the warm water regions of the North Pacific are assigned most frequently to the remarkable increase of $O$. longicauda and hence values of $\mathrm{F} / \mathrm{L}$ are usually lowered in the areas where appendicularians occur in quantities. Also, the number of individuals of $O$. fusiformis seems to be raised in these areas, but the increase is considered to be much smaller than that of O. longicauda. While, in the area corresponding to "the pacifica-dominant waters" proposed on the distribution of chaetognaths in the North Pacific, $\mathrm{F} / \mathrm{L}$ is raised significantly. Probably this is attributable to the sharp drop of $O$. longicauda in this waters, although we have to pay notices on such differences of $\mathrm{F} / \mathrm{L}$ between the samples collected from different depths at the same station as that found between the samples TP 131 and TP 131B (Appendix Table 6-4). The relative abundance of $O$. fusiformis in the superficial water was observed also in some samples collected in the Japan Sea as already mentioned on p. 385 . It is not impossible that $O$. fusiformis might be distributed more abundantly in the surface layer than in deeper lyyers under some conditions. However, the trend of $\mathrm{F} / \mathrm{L}$ towards the increase in "the pacificadominant waters" may be safely accepted as real, as the decrease of $O$. longicauda is recognized definitely in the cooler waters in the middle part of the Atlantic. O. longicauda quite disappears near the front of the warm waters in the Atlantic, but in the North Pacific there have not yet been found any wide areas where $O$. longicauda disappears completely and $O$. fusiformis is keeping the absolute predominancy, although the complete absence of $O$. longicauda is recorded at some stations. Contrarily, in the areas where the warm water is mixed with the cold water in the North Pacific, O. longicauda is the most remarkable species of all warm water forms. This seems to be one of the most remarkable characteristics of the North Pacific appendicularian fauna differing from that of the North Atlantic and reasonably this is attributable to the differences of hydrographic condition between these two oceans. In the southern South Pacific, there is found an area where $O$. longicauda is quite absent and $O$. fusiformis is keeping the predominancy (BARY 1960, see p. 398). O. rufescens shows the trend towards the increase in the tropical waters and the same as to $O$. cophocerca, $M$. huxleyi and Steg. magnum, the latter three are, however, found only sparsely in the waters even in tropics, where the neritic character is retained remarkably as is the case in the Arafura Sea.

Important fritillarians are Frit. borealis f. sargassi and Frit. pellucida and followed by Frit. formica; this order of abundance differs somewhat from that in the Atlantic. Frit. tenella and Frit. venusta are considered common in the tropical oceanic waters in the Pacific. Frit. haplostoma occurs widely in every 
collection, but not in abundance. In the Atlantic, evidently this species occurs abundantly in the coastal waters (p. 405), this is also true about the distribution of this species in the Pacific. Dense population of this species was recorded in the Pacific in Iwayama Bay of the Palao Islands, in Maizuru Bay on the Japan Sea coast of Honsyû Island, Japan and in Mori Inlet of Tanabe Bay near the Seto Marine Biological Laboratory. I have ever met with a dense population of this species along the southern coast near our laboratory, when the species occurred very abundantly in the superficial layer of a yellow brown water caused by a very small kind of ? Diplopsalis. On the other hand, the population of this species in the offshore oceanic water has never been raised to a significant degree. The possibility that Frit. abjornseni, an akin species to the present species, might be a neritic from, is mentioned already (p. 377), but here arises the possibility that the main propagating area of Frit. haplostoma is in the neritic waters and that individuals which are found in the far offshore oceanic waters and usually slightly larger may be drift forms. If this is true, Frit. haplostoma should be treated as a neritic water inhabitant just as App. sicula is done. Examining various collections, it seemed that individuals of Frit. haplostoma with wider tail musculature occurred more frequently and abundantly in samples from the eastern Pacific, for example the Shellback Expedition samples, but more crucial studies are needed to ascertain this inclination.

LoHMANN (1933, p. 106) mentioned that Frit. aberrans might be a deep water form. In the collections dealt with in this paper, this species occurred mostly in the deep water samples, too. Also Tectillaria taeniogona is considered to be a deep water form, because its state of preservation in samples collected by towing from, deep layers is mostly imperfect and more or less injured just as in Frit. aberrans.

$O$. dioica is the only appendicularian found in the strongly stagnant inlet waters or in somewhat brackish waters in the Pacific as in the Atlantic. The highest salinity $37.6 \%$ observed in Scammon's Lagoon on the west coast of Baja California is noted as a new record for $O$. dioica. $O$. longicauda is the commonest of all oceanic forms which are found in the embayments together with $O$. dioica. Abundant occurrences of $O$. fusiformis $\mathrm{f}$. cornutogastra in the lagoon water of the Palao Islands and near the middle part of the Arafura Sea together with $O$. dioica are considered to be attributable to the low refreshment degree of the lagoon water by the ocean water.

The geographical distribution of appendicularians was mentioned by LOHMANN (1933) and THOMPSON (1948), and FORNERIS (1959) summarized the previously published features indicating the differences found among the appendicularian faunas of the Atlantic, Mediterranean Sea, Indian Ocean and the Pacific. TokiokA showed the outline of the fauna in the Japanese waters in his paper of $1955 \mathrm{a}$. Consequently it is needless to repeat again on this subject. Here, only lists of 


\begin{tabular}{|c|c|c|c|c|c|}
\hline & $\begin{array}{l}\text { Gulf of } \\
\text { Mexico }\end{array}$ & Atlantic & $\begin{array}{c}\text { Mediterranean } \\
\text { Sea } \\
\end{array}$ & $\begin{array}{l}\text { Indian } \\
\text { Ocean } \\
\end{array}$ & Pacific \\
\hline O. longicauda & + & + & + & + & + \\
\hline O. intermedia & + & + & + & + & + \\
\hline O. fusiformis & + & + & + & + & + \\
\hline O. fusiformis f. cornutogstra & + & + & 一 & + & + \\
\hline O. gracilis & - & + & + & + & + \\
\hline O. graciloides & + & + & + & + & + \\
\hline O. dioica & + & + & + & + & + \\
\hline O. rufescens & + & + & + & + & + \\
\hline O. parva & + & + & + & + & + \\
\hline O. cophocerch & + & + & + & + & + \\
\hline O. mediterranea & - & - & + & - & + \\
\hline O. albicans & + & + & $\mp$ & + & + \\
\hline M. huxleyi & - & - & - & + & + \\
\hline M. abyssorum & 二 & + & + & - & + \\
\hline Steg. magnum & + & + & + & $1-$ & + \\
\hline Chunopleura microgaster & 二 & - & 一 & + & - \\
\hline Folia gracilis & - & + & \pm & - & + \\
\hline P. verticalis & - & + & - & + & + \\
\hline P. oppressa & 二- & + & 二 & $\cdots$ & - \\
\hline P. gracilis & 二- & + & - & $?+$ & + \\
\hline$P$. haranti & - & - & + & - & 二 \\
\hline Alth. tumida & + & + & - & 一 & + \\
\hline Sin. scrippsi & - & - & - & - & + \\
\hline Bathochordaeus charon & + & + & - & - & + \\
\hline Frit. haplostoma & + & + & + & + & + \\
\hline Frit. abjornseni & 二 & + & - & + & + \\
\hline Frit. arafoera & $=$ & - & 一 & 一 & + \\
\hline Frit. aberrans & 二 & \pm & - & - & + \\
\hline Frit. formica f. tuberculata & - & - & + & - & - \\
\hline Frit. formica f. digitata & + & + & + & $t$ & + \\
\hline Frit. fraudax & + & + & + & + & + \\
\hline Frit. gracilis & - & + & + & + & + \\
\hline Frit. charybdae & $\overline{-}$ & - & $+\frac{1}{1}$ & - & + \\
\hline Frit. urticans & 一 & - & + & - & - \\
\hline Frit. aequatorialis & - & + & + & - & - \\
\hline Frit. helenae & - & + & - & - & - \\
\hline Frit. drygalski & - & + & $?+$ & 二 & $=$ \\
\hline Frit pacifica & - & 二 & 一 & 二- & + \\
\hline Frit. pellucida & + & + & + & + & + \\
\hline Frit. borealis f. intermedia & \pm & + & + & $t$ & + \\
\hline Frit. borealis f. sargassi & + & + & + & + & + \\
\hline Frit. megachile & + & + & +1 & + & + \\
\hline Frit. tenella & + & + & + & - & + \\
\hline Frit. scillae & - & $t$ & + & - & - \\
\hline Frit. venusta & 二 & + & + & + & + \\
\hline T. fertilis & 二 & + & + & + & + \\
\hline$T$. taeniogona & 二 & - & - & - & + \\
\hline$A \overline{p p}$. sicula & + & + & + & + & + \\
\hline K. tenuis & + & + & + & - & + \\
\hline K. oceanica & - & - & \pm & - & - \\
\hline Number of species & 23 & 38 & 35 & 28 & 40 \\
\hline
\end{tabular}

Table 34. Occurrences of warm water-species of appendicularians in the world seas. 


\begin{tabular}{|c|c|c|c|c|c|}
\hline & Atlantic & $\begin{array}{c}\text { Mediterranean } \\
\text { Sea } \\
\end{array}$ & $\begin{array}{l}\text { Indian } \\
\text { Ocean } \\
\end{array}$ & Pacific & Notes \\
\hline o. fusiformis f. cornutogastra & + & - & + & + & $\mathrm{m}$ \\
\hline o. mediterranea & - & + & - & + & w \\
\hline M. huxleyi & - & - & + & + & $\mathrm{P}$ \\
\hline M. abyssorum & + & + & - & + & $\mathrm{w}$ \\
\hline Chunopleura microgaster & - & - & + & - & $\mathrm{n}$ \\
\hline Folia gracilis & + & + & - & + & w \\
\hline$P$. verticalis & + & - & + & + & $\mathrm{m}$ \\
\hline$P$. oppressa & + & - & - & - & n \\
\hline$P$. gracilis & + & - & $?+$ & + & $\mathrm{m}$ \\
\hline P. haranti & - & + & - & - & $\mathbf{M}$ \\
\hline Alth. tumida & + & - & - & + & m \\
\hline Sin. scrippsi & - & - & - & + & $\mathrm{P}$ \\
\hline Bathochordaeus charon & + & - & - & + & $\mathrm{m}$ \\
\hline $\begin{array}{l}\text { Frit. abjornseni } \\
\text { Frit. arafoera }\end{array}$ & \pm & - & + & + & $\mathrm{w}$ \\
\hline Frit. aberrans & + & - & - & + & $\mathrm{m}$ \\
\hline Frit. formica f. tuberculata & - & + & - & - & $\mathbf{M}$ \\
\hline $\begin{array}{l}\text { Frit. charybdae } \\
\text { Frit. urticans }\end{array}$ & - & + & - & \pm & $\mathrm{w}$ \\
\hline $\begin{array}{l}\text { Frit. aequatorialis } \\
\text { Frit. helenae } \\
\text { Frit. drygalski }\end{array}$ & $\begin{array}{l}+ \\
+ \\
+\end{array}$ & $\frac{+}{+}$ & $\begin{array}{l}- \\
- \\
-\end{array}$ & $\overline{-}$ & A \\
\hline Frit. pacifica & - & - & - & + & $\mathrm{P}$ \\
\hline $\begin{array}{l}\text { Frit. tenella } \\
\text { Frit. scillae }\end{array}$ & + & + & - & + & w \\
\hline T. taeniogona & 一 & - & - & + & $\mathrm{P}$ \\
\hline $\begin{array}{l}K . \text { tenuis } \\
K . \text { oceanica }\end{array}$ & + & + & - & + & $\mathrm{w}$ \\
\hline
\end{tabular}

Table 35. Warm water-species showing uneven distribution in the world seas. A $\cdots$ species occurring only in the Atlantic, M-species occurring only in the Mediterranean Sea, $\mathrm{m} \cdots$ species missing in the Mediterranean Sea, but present in the Atlantic; $\mathrm{n} \cdots$ species not yet sufficiently recognized, P...species occurring only in the IndoPacific, w $\cdots$ species presumably distributed widely in the world seas. 
warm water species in respective seas are presented (Tables 34 and 35) and some brief notes will be given. Of fifty forms listed in Table 34, 28 species occur unevenly in the world seas. Then of these 28 species, Chunopleura microgaster and Pelagopleura oppressa are known only by extremely few individnals and there might be some doubts about their validity. Frit. abjornseni and Frit. arafoera belong to the "Formenkreis" of Frit. haplostoma and hence their. presence or absence do not seem to be so significant for the appendicularian fauna of respective seas. Frit. charybdae and Frit. urticans are related very closely, and so are Frit. aequatorialis-Frit. helenae-Frit. drygalski, Frit. tenella-Frit. scillae and $K$. tenuis $-K$. oceanica. These couples or triplet may be treated here respectively as a "Formenkreis".

O. mediterranea, M. abyssorum, Folia gracilis, Frit. charybdae-urticans group, Frit. tenella-scillae group and $K$. tenuis-oceanica group are considered to be found distributing widely in all of these seas by future studies, although the first four belong to somewhat rare species. At present, $O$. fusiformis f. cornutogastra, $P$. verticalis, P. gracilis, Alth. tumida, Bathochordaeus charon and Frit. aberrans are known from both the Pacific and Atlantic, but not from the Mediterranean Sea; it is, however, not impossible that these might be discovered in the Mediterranean Sea in the future. On the other hand, P. haranti and Frit. formica f. tuberculata are the species unique to the Mediterranean Sea and the group of Frit. aequatorialis is the only one which can be said apparently characteristic of the South Atlantic and the Mediterranean Sea, being quite missing in the IndoPacific. There are following four species unique to the Indo-Pacific: $M$. huxleyi, Sin. scrippsi, Frit. pacifica and T.taeniogona, the latter three of which are known only from the Pacific to this date and do not occur so abundantly. Throughout the above-mentioned features of the geographical distribution, the absence of $M$. huxleyi in the Atlantic and the Mediterranean Sea, the confinement of the group of Frit. aequatorialis to the Atlantic and the Mediterranean Sea and the existence of Frit. formica f. tuberculata solely in the Mediterranean Sea may be accepted as the three important phenomena. In addition, the relative fewness of $O$. rufescens and Frit. borealis f. sargassi may be considered as a characteristic distributional aspect in the Mediterranean Sea and the abundant occurrence of $O$. longicauda in the northern mixing area between the warm water and the cold subarctic water is a remarkable feature characteristic to the North Pacific appendicularian fauna.

4) Distribution of doliolums. Although Doliolina intermedia is considered to occur most abundantly in the 200-1000 m layer of the ocean in the southern hemisphere (KRÜGER 1939), most other doliolids are evidently surface-water inhabitants as Thomfson showed that Doliolum denticulatum, Dolioletta gegenbauri var. tritonis and doliolids Amme were caught mostly in the 50-0 m layer during the survey in south-eastern Australian waters (1948, p. 100). Dolioletta gegenbauri is treated 
by some authors as a cool water species (BERRILL 1950), but apparently other doliolids are warm-water inhabitants. Even Dolioletta gegenbauri is reported from the tropical water, as RUSSELl and ColmaN (1935) collected it from the Great Barrier Reef region and TokıokA found it in the plankton collection from the Arafura Sea.

One of the most interesting subjects on doliolids must be the difference found between the distributions of Doliolum denticulatum and Doliolum nationalis. In the North Pacific, Doliolum denticulatum is distributed very widely and rather evenly in the whole warm oceanic waters, but it is quite absent or scarcely found in the Inland Sea of Japan, the Japan Sea and the inshore waters along the Californian coast; in these areas is found Doliolum nationalis which is, however, quite absent in the far offshore waters of the North Pacific. As to the distributional aspects of these two doliolids in the Atlantic, Garstang (1933) noticed that Doliolum nationalis occurred most abundantly in the equatorial zone during the Plankton Expedition and the "Tiefsee-Expedition" by the Valdivia and presented a supposition that this species, being found of the warm water, might be nothing but denticulatum differentiated early and arrested in growth and thus it might represent a quickly bred dwarf of the tropics. Later, KRÜGER (1939) notices that the areas rich of Doliolum nationalis were mostly located near the coast and that in the western section of the Guinea Current where Doliolum denticulatum was predominant during the "Meteor"-Expedition-"Dort aber, wo die Temperaturen über grosse Strecken gleich hoch bleiben, findet man Doliolum nationalis in den nahrungsreichen Gebieten". Of course, it is impossible to regard Doliolum nationalis as a cool-water species, but in the North Pacific this species does not seem to be distributed in the waters warmer than those in which Doliolum denticulatum is prevailing. Evidently the species is distributed much more northerly than Doliolum denticulatum in the Japan Sea and the north-eastern waters of Japan. $\mathrm{ZYL}_{\mathrm{YL}}$ (1960) mentions that Doliolum nationalis has its highest incidence during winter in the waters off the west coast of South Africa. The distribution of Doliolum nationalis in the North Pacific seems in most parts to conform well to that of a chaetognath, Sagitta bedoti, and partly to that of Sagitta friderici along the southern Californian coast. Most probably, at least in the North Pacific, Doliolum nationalis is considered to be distributed in the "bedoti and friderici waters" which are usually found along or near the coast and rich of nutrient microorganisms; these features resemble those of the distributional region of Doliolum nationalis in the Atlantic mentioned by KRÜGER. The distribution of Doliolum nationalis in the Atlantic seems to conform roughly to that of Sagitta friderici, too. For these reasons, I hesitate to accept GARSTANG's theory as to Doliolum nationalis, rather I prefer to consider that Doliolum nationalis is a form distinctly differentiated in the special water-mass, "bedoti"-or "friderici"-water, from the ancestor common to this and Doliolum denticulatum, although I can not 
judge exactly if the degree of this differentiation has already attained the level of a distinct species, that of a subspecies or a variety.

As to the morphological differences between Doliolum denticulatum and Doliolum nationalis, there is nothing to be added about the internal structure; only I want to note here that a reddish orange pigment fleck near the dorsal ganglion can be observed or retained much more frequently in Doliolum nationalis than in Doliolum denticulatum. This pigment fleck can be found on nearly all gonozooids or phorozooids of Doliolum nationalis. For instance, I examined in the end of 1956 quite optionally the whole specimens found in the Shellback samples SB 118 and SB 137 and found that two specimens from SB 118 and about 500 individuals from SB 137 were all provided with the pigment fleck. On the other hand, individuals of Doliolum denticulatum having such a pigment fleck were very few during the Shellback Expedition, the following are the percentage proportions of individuals having the pigment fleck in the examined samples.

\begin{tabular}{|c|c|}
\hline (SB 137) & 2 of 33 individuals.. \\
\hline (SB 142) & 3 of 41 individuals. \\
\hline (SB 160) & 1 of 35 individuals. \\
\hline 00) & 11 of 138 individuals. \\
\hline .0) & dividuals \\
\hline
\end{tabular}

Those individuals having the pigment fleck seemed to be rather small. The maximal body length of Doliolum denticulatum in respective samples varied from $4.6 \mathrm{~mm}$ (SB 105) $5.2 \mathrm{~mm}$ (SB 115) to $9.1 \mathrm{~mm}$ (SB 109), while that of Doliolum nationalis was $3.6 \mathrm{~mm}$ (SB 112) or $3.9 \mathrm{~mm}$ ( $\mathrm{SB} \mathrm{115).}$

The distribution of Doliolette gegenbauri var. tritonis in the North Pacific resembles very closely that of Doliolum nationalis. Although $Z_{\mathrm{YL}}(1960)$ considers this form might be an oceanic form, it is very possible that its distribution is closely related with the "bedoti"-or "friderici"-waters. It seems, however, that the distribution of this species is extended more towards the ocean centre than that of Doliolum nationalis. The results of oceanographical observations made in the sea east of Honsyû Island May-June, 1959 (Oceanographic Section of Japan Meteorological Agency 1960) show distinctly the above-mentioned distributional features of Dolioletta gegenbauri var. tritonis. Namely, this doliolum occurred very abundantly in the surveyed area together with Doliolum denticulatum. The former was, however, distributed in the inshore waters along Bôsô Peninsula and extending northwards to the $10^{\circ} \mathrm{C}$ isotherm and also in wide stagnant water masses found along the northern side of the main stream of the extension of the Kurosio, stretching in the areas respectively between $144^{\circ} \mathrm{E}$ and $152^{\circ} \mathrm{E}$, and $154^{\circ} \mathrm{E}$ and $158^{\circ} \mathrm{E}$, but it scarcely appeared in the waters south of the main stream of the Kurosio. On the other hand, Doliolum denticulatum occurred most abundantly in the waters south of the main stream of the Kurosio, although small numbers of individuals were found together with the preceding species in 
the northern waters beyond the Kurosio between $154^{\circ} \mathrm{E}$ and $158^{\circ} \mathrm{E}$ and also in the inshore waters. The main stream of the Kurosio was traced to $157^{\circ} \mathrm{E}$ between $34^{\circ} \mathrm{N}$ and $36^{\circ} \mathrm{N}$ at that time (Fig. 13). Then it is rather strange that Dolioletta gegenbauri var. tritonis was not found in any collections made in the Japan Sea, though further studies are needed to ascertain whether or not the species is constantly absent in this sea.

The "Challenger" collected Doliolum denticulatum at various parts of the North and South Pacific (HERDMaN 1888), but it is quite unknown whether or not this involves Doliolum nationalis. The "Vettor Pisani" also recorded Doliolum denticulatum at many of her Pacific stations distributing along her course stretching between Callao of the eastern Pacific and Cape Batangan on the eastern coast

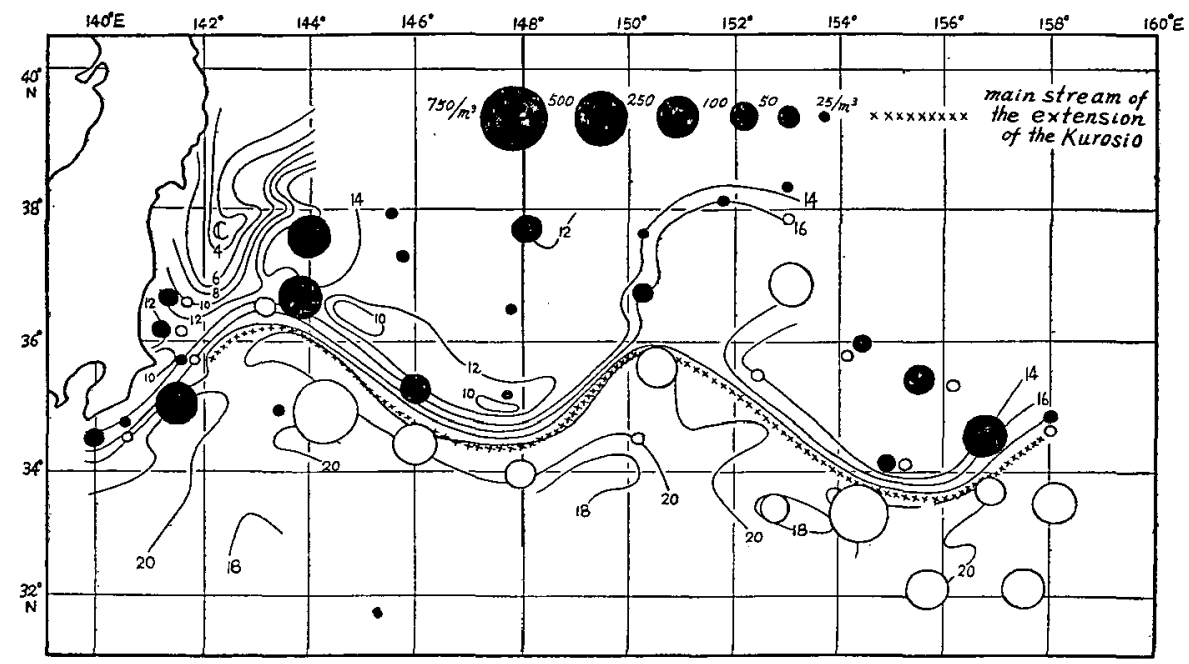

Fig. 13. Distributions of Dolioletta gegenbauri var. tritonis (solid circle) and Doliolum denticulatum (empty circle) in the sea east of Honsya Island, with isotherms at $100 \mathrm{~m}$ layer. (Oceanographic Section of Japan Meteorological Agency 1960, Fig. 3-3 on p. 31)

of Annam via Hawaii and Philippines and Dolioletta gegenbauri var. tritonis at Hong Kong (Borgert 1896). Neumann (1913, p. 31) found Dolioletta gegenbauri and Doliolina krohni in the collection of the "Planet" made at Hong Kong on Feb. 15, 1907. All these records are considered not to conflict with the abovementioned general distributional aspects of the Pacific doliolids.

The doliolid fauna of the Shellback area seems to resemble closely that of the eastern part of the South Atlantic in harbouring Doliopsoides and considerable numbers of Doliolina intermedia, the distribution of the latter is also extended to the northern hemisphere in the Pacific.

5) Distribution of salps. 
After Thomfson listed previous works on Pacific salps in his book "Pelagic Tunicates of Australia" in 1948, six subsequent papers on Pacific salps have appeared, two by Yount (1954 and 1958) dealing with salps occurring in the Central Pacific, two by BERner (1954 and 1955) treating two new salps and a newly discovered aggregated form of Ritteriella picteti, one by FAGETTI (1959) on salps occurring in the waters along the coast of North and Central Chile and one by BARY (1960) on the collection made in south-eastern New Zealand waters. Besides, there are ToKIoKA's fragmental notes and records of some salps came from various parts of the Pacific (TokrokA $1951 \mathrm{a}, \mathrm{b} ; 1954,1955 \mathrm{~b}, 1960$; HANEDA \& ToKIOKa 1954, Tokioka \& Berner $1958 \mathrm{~b}$ ). Throughout the results of the

\begin{tabular}{|l|l|}
\hline Thalia democratica & $63 \%$ \\
\hline Salpa fusiformis & 43 \\
\hline Brooksia rostrata & 17 \\
\hline Cyclosalpa pinnata & 13 \\
\hline Salph cylindrica & 12 \\
\hline Cyclosalpa floridana & $5+$ \\
\hline Pegea confoederata & $5+$ \\
\hline Iasis zonaria & $5-$ \\
\hline Thetys vagina & 3 \\
\hline Traustedtia multitentaculata & 3 \\
\hline Cyclosalpa affinis & 2 \\
\hline Salpa fusiformis f. aspera & 2 \\
\hline Salpa maxima & 1 \\
\hline Ihlea punctata & 1 \\
\hline
\end{tabular}

Table 36. Frequency of occurrence of 14 Atlantic salps in 111 samples collected during the Plankton Expedition (from Apstein 1894, pp. 42-43).

examination published here and all those papers mentioned above or listed in ThOMfSON's book, it is evident that Thalia democratica is the commonest salp occurring most frequently and abundantly in the warm water region of the Pacific. In the tropical waters, Salpa cylindrica is abundant next to the preceding species and followed by Brooksia rostrata, Salpa fusiformis and Iasis zonaria in samples towed in the surface $50-0 \mathrm{~m}$ layer; Brooksia rostrata is, however, very fragile in consistency and rarely found in a perfect condition. In samples hauled from deeper layers, Salpa fusiformis, Ritteriella amboinensis and Metcalfina hexagona are rather common. Salpa fusiformis increases in the temperate waters and con- 
stitutes the most important part of the salp population in the mixing area between the cold subarctic water and the warm water in the North Pacific, while in the southern mixing area between the cold subantarctic water and the warm water Salpa fusiformis occurs commonly together with Ihlea magalhanica. In both northern and southern mixing areas, Salpa fusiformis is represented frequently by echinated forma aspera. Roughly saying, the above-mentioned distributional aspects of important salps seem to be common to the Pacific, the Atlantic and also to the Indian Ocean (Table 36).

As the occurrence of var. orientalis of Thalia democratica, characterized by having distally furcated atrial palps instead of distally pointed ones, has been reported only by SEwell (1953) from the Indian Ocean, by Yount (1954) from the Central Pacific and by BERnARd (1958) from the Bay of Alger, besides TokiokA's fragmental notes, this variety seems to be confined to the Indopacific and the Mediterranean Sea, but quite missing in the Atlantic. Dealing with a considerable number of samples and gathering the data about Thalia democratica, I have tried to find out if the distribution of the typical form and that of var. orientalis are segregated from each other. However, so far as the results of the present examinations are concerned, the distributional aspect of the typical form and that of var. orientalis are quite similar, generally both forms occurring mingled with each other. It seems, however that var. orientalis is very common in the Japanese waters; this point will be made clear by further statistical studies in the future. The variety orientalis is also known from the South Pacific (Tokioka 1960).

6) Concluding remarks.

Throughout these observations, distributions of dense populations of appendicularins, values of $\mathrm{F} / \mathrm{L}$, Doliolum nationalis and Dolioletta gegenbauri var. tritonis in the North Pacific seem to support the idea that the "bedoti"-and "friderici"waters, and probably also the enflata-dominant water in the equatorial zone, which were all proposed in my paper of 1959 on the basis of the distributional aspects of chaetognaths of the North Pacific, are separable from the far oceanic water of the North Pacific as distinct water masses. And this seems to prove that Doliolum nationalis is not an ecological form of Doliolum denticulatum but a distinct form differentiated in and confined to the special water mass.

At the same time, results of the observations on chaetognaths and pelagic tunicates of the North Pacific seem to show that some of the plankton animals living in the surface layer of the warm oceanic waters might be divided into the following groups :

1-Distribution confined to some (eutrophic) water masses

Sagitta bedoti, Sagitta friderici, Doliolum nationalis and ? Dolioletta gegenbauri var. tritonis

2-Distribution extending nearly to all parts of the ocean, but

$$
-202-
$$


a-Population density heightened remarkably in the eutrophic waters

Sagitta enflata and Oikopleura longicauda

b-i) Contrarily the density rather lowered there

Sagitta serratodentata pacifica, Oikopleura cophocerca, Oikopleura albicans, Megalocercus huxleyi and Stegosoma magnum

ii) or Population density without any remarkable increase in the eutrophic waters

Oikopleura fusiformis and Oikopleura rufescens

The eutrophic water masses harbouring Sagitta bedoti, Sagitta friderici, Doliolum nationalis and Dolioletta gegenbauri var. tritonis are the "bedoti"- or "friderici"waters located near the coast, while the eutrophic waters harbouring rich Sagitta enflata and Oikopleura longicauda include the "bedoti"- and friderici"-waters and the equatorial zone.

\section{MORPHOLOGICAL NOTES ON SOME APPENDICULARIANS AND THALIAC EANS}

(Text-figs. 14-16)

1) Colouration of some appendicularians. Although the whole body may rarely be coloured violet, red or yellow in O. longicauda, the colouration most frequently observable in this species is a faint purplish tint found on the stomach and intestine, while the rectum is usually seen yellowish orange by its contents. This colouration can often be seen on living specimens of many other species. Rarely the anterior part of the trunk is coloured reddish brown in this species as well as in $O$. fusiformis and $O$. dioica. The orange stomach of $O$. dioica was observed in the vicinity of Seto, Japan and at Station 2 in the blue-green water along the southern Californian coast. On the other hand, the partial colouration in rose red seems to be rather usual in some species : rose red oikoplast epithelium was found once in a specimen of $O$. rufescens from St. 73 near the Palao Islands, rose red pharynx bottom holding the endostyle was observed in a specimen of O. rufescens from Palao, a specimen of $O$. fusiformis collected off Minabe, Kii Japan, Transpac Expedition specimens of $O$. fusiformis f. cornutogastra and a Transpac Expedition specimen of $O$. intermedia, rose red stomach in many specimens of $O$. rufescens, $O$. intermedia and $O$. fusiformis f. cornutogastra all collected in the surrounding waters of the Palao Islands and lastly scarlet pigmentation on the surface of testes was found in a single specimen of O. rufescens collected near Seto, Japan. Very strange is the reddish contents of the intestine found in a specimen of $O$. longicauda collected at the Transpac Expedition Station 135. The tail of $M$. huxleyi may look faintly pinkish against the white background, while bluish on the dark object; of course these are not the true colouration. 
A specimen of Frit. formica was found having a series of reddish orange round pigment flecks along the middle of the tail (Ток гок A $1951 \mathrm{~b}$ ), and here is presented a specimen of Frit. pellucida collected in the vicinity of Seto, Japan, which is coloured dark reddish orange on the antero-ventral portion of the trunk, while the stomach is yellow and transparent, the intestine yellow and opaque, the gonad milky and spiracles are whitish.

2) Colouration of some thaliaceans. Living specimens of Dolioletta gegenbauri var. tritonis are often coloured faintly in purplish, but those found in a swarm appeared near our laboratory on January 25, 1939 were coloured faintly reddish brown as a whole, the stomach being quite transparent like an oil drop and the right postero-ventral side of the coil of the alimentary organ pigmented in reddish orange.

The nucleus of Salpa fusiformis or Salpa cylindrica is yellowish white or yellowish in smaller specimens, but it is coloured reddish orange and dark greenish or greenish brown in larger specimens in both solitary and aggregated forms. The nucleus of Thalia democratica is whitish in smaller individuals, but yellowish or orange in the grown ups. Both the solitary and aggregated forms collected at the Sôyô-maru Station 30, 1939 near the southern end of Kyûsyû Island, Japan had nuclei unusually coloured in vermilion. The nucleus of Pegea confoederata is usually purplish brown. The intestinal loop of the aggregated form of Cyclosalpa affinis is yellowish brown or greenish yellow.

3) Subchordal cells in some species of Oikopleura (Vexillaria) (Fig. 14).

(a) O. cophocerca: The tail musculature of this species seems to be comparatively rigid so that the tail is found in a satisfactory state of preservation in most samples. Subchordal cells varies much in number; usually they are \pm 9 in matured specimens, but they may be up to 12 in specimens collected near our laboratory and attain 17 in a Palao specimen. The results of examination on 19 specimens came from Seto and Palao show the following numbers of subchordal cells.

\begin{tabular}{|c|c|c|c|}
\hline \multicolumn{2}{|c|}{3 cells........1 individual } & \multicolumn{2}{|c|}{11 cells........2 individuals } \\
\hline 5 & ........1 & 12 & $\ldots \ldots \ldots 1$ \\
\hline 6 & ........3 & 13 & $\ldots \ldots \ldots 2$ \\
\hline 7 & .......2 & 14 & ........1 \\
\hline 8 & $\ldots \ldots \ldots 4$ & 17 & ........1 \\
\hline 10 & $\ldots \ldots, 1$ & & \\
\hline
\end{tabular}

In younger specimens they are most often 4, although they may be 3 (in addition to the above-listed individual, a specimen from SB 145), 2 (a specimen from MP 2) or completely missing (specimen from SB 166, Station 78 in the neighbouring waters of the Palao Islands). Frequently they are found being divided into two groups as mentioned already in my previous note $(1955 \mathrm{c})$. The tail having four subchordal cells reminds us of that of $O$. najadis which has also four subchordal cells and a comparatively wide musculature. 
(b) O. parva: Four subchordal cells may be arranged in two groups as in some young specimens of $O$. cophocerca (Fig. 14D). The tail musculature is, however, much narrower than in the preceding species.

(c) O. albicans: Many individuals collected at the station SB 195 of the Shellback Expedition were remarkable in that subchordal cells were much fewer than usual or quite obsolete, although it was quite unknown what the cause was.

4) Size of some appendicularians.

(a) O. fusiformis f. cornutogastra: AIDA (1907) mentioned that his specimen was $1049 \mu$ in trunk length and ThOMPson (1948) stated that maximal trunk length was $2.0 \mathrm{~mm}$ in south-eastern Australian waters. The specimens collected in the lagoon waters of the Palao Islands were, however, somewhat smaller than in those

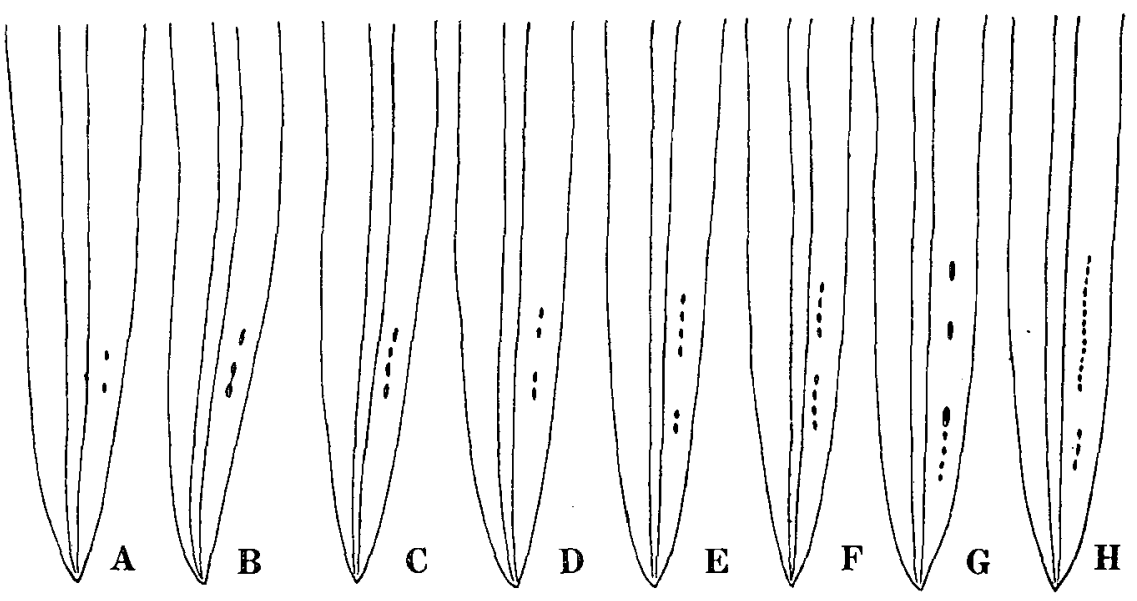

Fig. 14. Oikopleura cophocerca Gegenbaur. Tails with various numbers of sub-

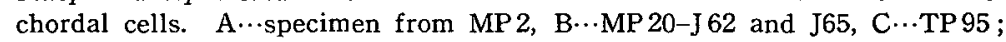

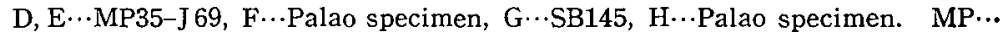
Midpac Expedition station, SB...Shellback Expedition station, TP... Transpac Expedition station.

described by previous authors, they were mostly $600-800 \mu$ in trunk length, the maximum was $985 \mu$ and the minimum of the matured specimens was $362 \mu$.

(b) O. dioica: While I was examining the specimens of this species collected in the blue-green water along the southern Californian coast, I found a $325 \mu$ long (in trunk length) individual having the gonad in a half matured state and this seemed to be the minimum of matured individuals in that collection.

(c) M. huxleyi: The specimens found in the collection made in the neighbouring waters of Korea were very large, ranging from 3.5 to $4.5 \mathrm{~mm}$ in body length and $15-18 \mathrm{~mm}$ in tail length, although these values are slightly less than those recorded by THOMPSON (1948) in south-eastern Australian waters, $5.8 \mathrm{~mm}$ in body length and $20 \mathrm{~mm}$ in tail length. 
(d) Bathochordaeus sp.: The tail specimen found in the sample from the Shellback Expedition Station SB 170 was $18 \mathrm{~mm}$ long, $6.5 \mathrm{~mm}$ wide at the broadest level and with the $2 \mathrm{~mm}$ wide musculature and considered apparently to belong to a certain appendicularia. The similar piece came from SB 68 was ca. $20 \mathrm{~mm}$ in length and $8.0 \mathrm{~mm}$ wide at the distal end where the tail fin seemed to have its maximum breadth. It is quite impossible that such large and strangely shaped tails belong to another form else than Bathochordaeus sp.; very probably these are tails of $B$. charon.

(e) Frit. formica: A specimen from the Shellback Expedition Station SB 40 was
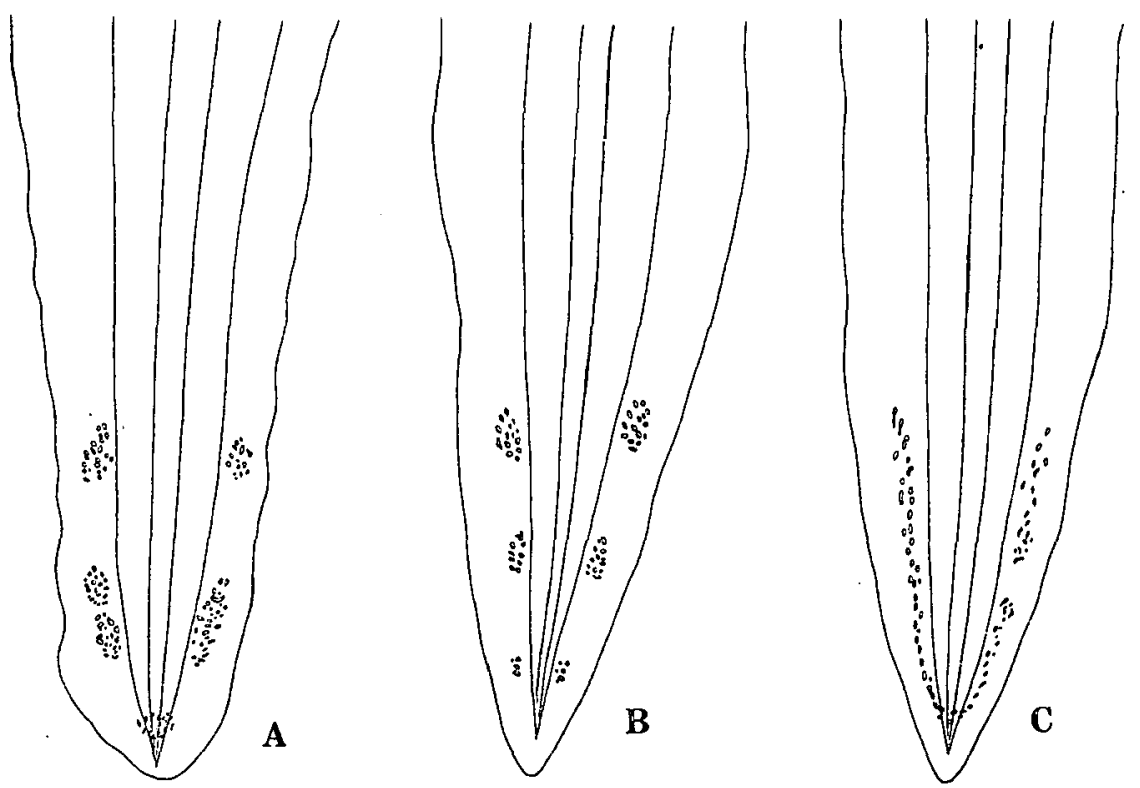

Fig. 15. Pelagopleura verticalis (LoHMANN). Different arrangements of amphichordal cells on the tail in specimens collected off southern California.

$2.0 \mathrm{~mm}$ in trunk length and $4.1 \mathrm{~mm}$ in tail length. Probably this size is the new record for the present species.

5) Morphology of some appendicularians (Text-fig. 15).

(a) O. rufescens: The vertically descending rectum is available as a very useful character of this species when imperfectly preserved specimens are treated for identification.

(b) Steg. magnum: The posterior end of the left stomach lobe is rounded in younger individuals, but it becomes acute in old individuals.

(c) P. verticalis: Several specimens collected in June 1951, 160 miles off Baja California near islands were offered me for examination by courtesy of Dr. LEo BERNER. Gonads are arranged in just the same way as that found in those 
specimens described by Tokioka (1955 a) The width of chorda is 30 to $37.5 \%$ of that of the musculature and $34.4 \%$ on an average. Amphichordal cells are usually divided into several groups, but the grouping may become quite obsolete in some specimens. I am inclined to consider that three LoHMANN's species, $P$. verticalis, $P$. oppressa and $P$. gracilis, are quite identical with one another and belong to the single species represented by verticalis according to the page priority. Very probably $P$. oppressa is the youngest form, then $P$. verticalis and $P$. gracilis is the fully matured one.

(d) Frit. haplostoma: Frequent occurrences of individuals having broader tail musculature in the eastern Pacific is mentioned already on p. 416 For example, 15 specimens from the Shellback Expedition Station SB 60 consisted of 9 individuals having wider musculature and five with very narrow musculature. Generally speaking, specimens with wider musculature are provided with roundish spiracles.

(e) Frit. fraudax: Superficially this species resembles Frit. gracilis and the resemblance is especially remarkable in immature individuals. However, young individuals of Frit. fraudax can be separated distinctly from those of Frit. gracilis by having much broader tail musculature and relatively larger alimentary organ. In Frit. fraudax there is a prominent triangular glandular projection on the left side of stomach and a couple of minute gland cells are found along the posterior margin of this projection.

(f) Frit. borealis $\mathrm{f}$. sargassi: Usually the posterior side of the trunk is rounded and has a small prominence at the middle (Tokioka 1950), while a specimen from the Transpac Expedition Station TP 93 was found being truncate at the posterior end of the trunk even in a perfectly preserved state.

(g) Frit. tenella: Some authors seem to be of the opinion thas this species might be identical with Frit. megachile. In addition to that the latter has much more elongate trunk and a pair of amphichordal cell groups of quite different structure, there is further a more distinct difference between these two species and this may be used as an easy clue distinguisning these two species from each other. The stomach and intestine of Frit. magachile are surfaced very simply and without any glandular appendages, while the intestine of Frit. tenella is always provided with several appendages or prominences. The tail fin widely and clearly cut in at the distal end may be accepted as a sign to show the specimen may belong to Frit. megachile or Frit. tenella.

6) Characteristics of Thalia democratica var. orientalis (Text-fig. 16).

As I stated already in my short note dealing with the specimens collected near Noumea, New Caledonia, the bifurcate appearance of atrial palps of var. orientalis can be seen even in a very earlier stage of development of solitary form. For instance, a $2.5 \mathrm{~mm}$ long (excluding the protuberances) individual just left the mother individual found in the sample collected at SB 187 was found 
having already bifurcate palps. Intermediate forms are seldom found between the typical and orientalis forms. As far as the specimens dealt with here in this paper are concerned, only three individuals are considered to show intermediate states. One of the three typical forms from SB 130 had the palps shown in $B$ of Fig. 16, and two of 310 typical forms from SB 137 were provided with palps shown in $\mathrm{C}$ of the same figure. When the typical and orientalis forms are captured together, they are often separable from each other by their different appearance of the body. For example, typical forms may be rather rigid in body consistency and furnished with stouter muscles, while orientalis forms may be somewhat soft and provided with narrower muscles. This seems to show evidently that these two forms can not be merely insignificant intraspecific variants found among the individuals belonging to the same stock, but they might belong respectively to different stocks.
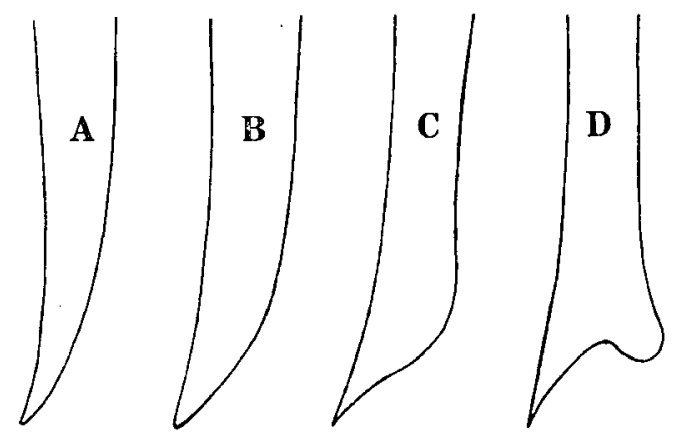

Fig. 16. Thalia democratica (FORSKÅL), solitary form. Atrial palp of A...typical form, $\mathrm{D} \cdots$ var. orientalis Tokrok $\mathrm{A}, \mathrm{B}$ and $\mathrm{C} \cdots$ ? possible intermediate forms found in stocks of the typical form.

7) Parasitic organism of appendicularians. In the inner parts of Tanabe Bay near our laboratory, $O$. dioica is often found infested by club-shaped spores of Gromia sp. on the body surface.

\section{SUMMARY AND CONCLUSIONS}

1. Pelagic tunicates found in the same plankton collections with those treated in my previous paper (1959) on the taxonomy and distribution of chaetognaths of the North Pacific were examined and the crude data are given in 13 appended tables Data from samples collected in the Japanese and adjacent waters, the surrounding waters of the Palao Islands, the Arafura Sea and the Indian Ocean are also given in 6 appended tables. Besides, available data from 
various publications were examined so that the distribution of pelagic tunicates of the North Pacific could be compared with those of other seas.

2. In all 40 forms of appendicularians were found in the material, four of these are known only from the Indo-Pacific, while the group of Frit. aequatorialis is quite missing in the Indo-Pacific. The constitutions of the population of the North Pacific warm-water appendicularians resembles roughly that of the Atlantic. However, the occurrence of rich $O$. longicauda in the northern mixing area between the subarctic and warm waters seems to be unique to the North Pacific.

3. Dense populations of appendicularians and lower values of $F / L$ are seen in the North Prcific in the "bedoti"- or "friderici"-waters and also in the equatorial zone, while the density is low and the number of occurring species is few in the north-eastern quarter of the North Pacific Central Water Mass.

4. Frit. haplostoma and App. sicula might belong to the neritic form rather than to the oceanic form.

5. Doliolum nationalis is a distinct form quite differentiated from Doliolum denticulatum and its distribution seems to be confined to the "bedoti"- or "friderici"waters in the North Pacific. The distribntion of Dolioletta gegenbauri var. tritonis is possibly related closely that of Doliolum nationalis.

6. The distributional aspects of dense appendicularian populations, values of $\mathrm{F} / \mathrm{L}$ and Doliolum nationalis seem to support that the "bedoti"- or "friderici"-waters are separable from the far oceanic water mass as distinct water masses. The first two of three items are considered to approve the existence of a special eutrophic water mass in the equatorial zone.

7. The typical form and var. orientalis of Thalia democratica occur in the North Pacific, being mingled with each other.

8. ESSENBERG's appendicularian species are wholly reviewed, and some morphological notes are given on some pelagic tunicates.

\section{REFERENCES}

AIDA, T. (1907): Appendicularia of Japanese waters. Jour. Coll. Sci. Imp. Univ. Tokyo, Vol. 23, Art. 5, pp. 1-25, 4 pls.

Apstein, C. (1894): Die Thaliacea der Plankton-Expedition. B. Verteilung der Salpen. Ergebn. Plankton-Exped., Bd. $2 \mathrm{E}$ a, pp. 1-68, pls. 2-4.

(1904): Salpes d'Amboine. Rev. Suiss Zool., Vol. 12, pp. 649-656, pl. 12.

(1906a): Salpen der deutschen Tiefsee-Expedition. Ergebn. Deutsch. Tiefsee-Exped. 1898-99, Bd. 12 (3), pp. 245-290, pls. 26-32.

(1906b): Die Salpen der deutschen Südpolar-Expedition. Ergebn. Deutsch SuidpolarExped. 1901-03. Bd. 9 (Zool. 1), pp. 155-203, pls 8-10.

BARY, B. M. (1960): Notes on ecology, distribution, and systematics of pelagic tunicates from New Zealand. Pacific Science, Vol. 14, No. 2, pp. 101-121, 25 text-figs.

Bedot, M. (1909): Sur la Faune de l'Archipel Malais (Résumé). Rev. Suiss Zool., Tom. 17, pp. 143-169.

BERNARD, M. (1954): Capture de Megalocercus abyssorum ChUN (Oikopleuridae) dans la baie d'Alger. Trav. C. L. O. E. C. d'Alger, No. 23, pp. 344-347, 2 text-figs. 
(1958): Systematique et distribution saisonnière des tuniciers pélagiques d'Alger. Comm. Internat. Expl. Sci. Mediter. Rap. Proc.Verb. Réunions, Vol. 14 (n. s), pp. 211-231, 15 text-figs.

BERNER, LEo D. (1954): On the previously undescribed aggregate form of the pelagic tunicate Ritteriella picteti (APSTEIN) (1904). Pacific Science, Vol. 8, No. 2, pp. 121-124, 4 text-figs. (1955): Two new pelagic tunicates from the eastern Pacific Ocean. Pacific Science, Vol. 9, No. 2, pp. 247-253, 8 text-figs.

BERRILL, N. J. (1950): The Tunicata with an account of the British species. Ray Society. pp. 268-322, text-figs. 97-120.

Bigelow, H. B. \& Leslie, M. (1930): Reconnaissance of the waters and plankton of Monterey Bay, July, 1928. Bull. Mus. Comp. Zool. Harvard Coll., Vol. 70, No. 5, pp. 427-581, 43 text-figs.

BJörnberG, T. K. S. \& Forneris, L. (1955): Resultados cientificos do cruzeiro do "Baependi" e do "Vega" a ilha de Trinidade. Copelata 1. Univ. São Paulo, Contr. Avul. Inst. Oceanogr., Oceanogr. Biol., No. i, pp. 1-68, 17 pls.

$\&$ - (1956a): On the uneven distribution of the Copelata of the Fernando de Noronha area. Bol. Inst. Oceanogr. São Paulo, Vol. 7, Fasc. 1-2, pp. 105-111, 3 text-figs.

\& - (1956b): On the uneven distribution of the Copelata of the Alcatrazes area. Ibid., Vol. 7, Fasc. 1-2, pp. 113-116, 2 text-figs.

BOMFORD, T. L. (1913): Some salpas taken by R. I. M. S. S. Investigator in the Bay of Bengal and Andaman Sea. Rec. Indian Mus., Vol. 9, Miscell.

Borget, A. (1894): Die Thalicacea der Plankton-Expedition. C. Vertheilung der Doliolen. Ergebn. Plankton-Exped., Bd. 2 E a c, 68 pp., pls. 5-8. pp. 714-719.

Brooks, W. K. \& Kellner, C. (1908): The pelagic tunicata of the Gulf Stream. Part 4. On Oikopleura tortugensis, a new appendicularian from the Tortugas, Florida, with notes on its embryology. Papers from the Tortugas Laboratory of the Carnegie Inst. Washington, Vol. 1, pp. 73-94.

BÜCKMANN, AD. (1924): Bemerkungen über Appendicularien aus der Ausbeute der Deutschen Südpolarexpedition. Zool. Anz., Bd. 59.

(1926): Die Tierwelt der Nord- und Ostsee. Teil 12 a 1, Lief. 5.

ChUN, C. (1888): Die pelagische Tierwelt in grösseren Meerestiefen und ihre Beziehungen zu der Oberflächenfauna. Bibliotheca Zoologica, Hft. 1, pp. 1-72, pls. 1-5. (1900): Aus den Tiefen des Weltmeeres. pp. 518-521, Jena.

DolgopolskaIA, M. A. (1940): Das Zooplankton des Schwarzen Meeres in der Nähe von Karadag. Trav. Stat. Biol. Karadagh, Fasc. 6, pp. 57-111.

EssenberG, Ch. D. (1922): The seasonal distribution of the appendicularia in the region of San Diego, California. Ecology, Vol. 3, No. 1, pp. 55-64, 3 text-figs. (1926): Copelata from the San Diego Region and observations on gradual disintegration and death of Copelata. Univ. California, Publ. Zool., Vol. 28, No. 23, pp. 399-525, 170 text-figs.

FAgetti Guaita, Elda (1959): Salpas colectadas frente a las costas central y norte de Chile. Rev. Biol. Mar., Valparaiso, Vol. 9, Nos. 1-3, pp. 201-228, 7 pls., 1 text-fig.

FENAUX, R. (1959a): Observations écologiques sur les appendiculaires du plancton de surface dans la Baie de Villefranche-sur-Mer. Bull. Inst. Océanogr., No. 1141, 26 pp.

(1959b): Considérations sur la valeur spécifique de Megalocercus atlanticus LoHM. 1914. Ibid., No. 1161, 6 pp., 6 text-figs.

For, H. (1872): Etudes sur les appendiculaires du détroit de Messine. Mém. Soc. Phys. Hist. Nat. Cenève, Tom. 21, No. 2, pp. 445-498, 11 pls. 
(1874): Note sur un nouveau genre d'Appendiculaires. Arch. Zool. Expér., 3 pp. 4953, pl. 18.

ForNerts, L. (1957): The geographical distribution of the Copelata. Anais d. Acad. Brasil. d. Ciencias., Vol. 29, No. 2, pp. 273-284.

FRASER, J. H. (1949): The distribution of Thaliacea (Salps and Doliolids) in Scottish waters 1920 to 1939. Scottish Home Dept., Fish. Div. Sci. Invest, 1949, No. 1, 44 pp., 16 text-figs.

(1954): Warm-water species in the plankton off the English Channel entrance. J. Mar. biol. Ass. U. K., Vol. 33, pp. 345-346.

FURNESTIN, M.-L. (1958): Observations sur quelques échantillons de plancton du détroit de Gibraltar et de la Mer d'Alboran. Comm. Internat. Expl. Sci. Mediter., Rap. Proc.-Verb. Réunions, Vol. 14 (n. s.), pp. 179-183, 1 text-fig.

Ganapati, P. N. \& Bhavanarayana, P. V. (1958): Pelagic tunicates as indicators of water movements off Waltair coast. Current Science, 27, pp. 57-58.

Garstang, W. (1933): Report on the Tunicata. Part 1. Doliolida. British Antarctic ("Terra Nova") Exped. 1910, Nat. Hist. Rep. Zool., Vol. 4, No. 6, pp. 195-251, 8 text-figs.

(1937): On the anatomy and relation of the appendicularian Bathochordaeus based on a new species from Bermuda (B. stygius sp. n.). Linn. Soc. Zool., Vol. 40.

Garstang, W. \& Georgeson, El. (1935): Report on the Tunicata. Part 2. Copelata. British Antarctic ("Terra Nova") Exped. 1910, Nat. Hist. Rep. Zool., Vol. 4, No. 8, pp. 263-282, 5 text-figs.

HANEDA, Y. \& TokiokA, T. (1954): Droplets from the plankton net 15. Record of a caudate form of Pegea confoederata from the Japanese waters, with some notes on its luminescence. Publ. Seto Mar. Biol. Lab., Vol. 3, No. 3, pp. 369-371, text-figs. 16-17.

Hastings, A. B. (1931): Tunicata. Great Barrier Reef Exped. 1928-29, 1928-29, Sci. Rep., Vol. 4, No. 3, pp. 105-107.

Herdman, W. A. (1888): Report upon the Tunicata collected during the voyage of H. M. S. Challenger during the years 1873-76. Part 3. Challenger Report, Zool. Vol. 27, 166 pp., 11 pls., 28 text-figs.

HoKkAIDO FISHERy EXPERIMENT Station (1934): Reports of the fishery surveys, No. 36, pp. 39 \& 74.

IHLE, J. E. W. (1908): Die Appendicularien der Siboga-Expedition. Siboga-Exped., Monogr. 56 c, 123 pp., 4 pls., 8 text-figs.

- (1910): Die Thaliaceen (einschliesslich Pyrosomen) der Siboga-Expedition. Siboga-Exped., Monogr. $56 \mathrm{~d}$.

(1929): Ueber Megalocercus diegensis EssenBerg 1926. Zool. Anz., Bd. 85, pp. 333-335.

pp. $401-532$.

(1935): Desmomyaria in Kükenthal \& Krumbach : Handb. d. Zool., Bd. 5, Part 2,

(1958): Salpidae in BronNs Klassen u. Ordnungen d. Tierreichs, Bd. 3, Suppl. Tunikaten, 2 Abt., 2 Buch, 4 Lief., pp. 350-364, text-figs. 310-313. (part. concerning the distribution)

IHLE, J. E. W. \& IhLE-LANDenberG, M. E. (1935): Ueber eine kleine Salpen-Sammlung aus der Javasee. (Zugleich: Anatomische Untersuchungen über Salpen 5). Zool. Anz., Bd. 110, Hft. 1-2, pp. 19-24, 2 text-figs.

Komaii n. sp. Publ. Staz. Zool. Napoli, Vol. 15, Fasc. 2, pp. 274-283, 3 text-figs.

(1938): Cyclosalpa komaii. Annot. Zool. Japon.,

Vol. 17, Nos. 3-4, pp. 609-611.

InzukA, A., Yosida, K. \& KurohagI, T. (1951): The peculiarities found in the spring-summer plankton of 1950 in the neighbouring waters of Isikari Bay. Hokusuisi Geppô (Monthly Journal from the Hokkaidô Fishery Experiment Station), Vol. 8, No. 2, pp. 14-19, 3 text-figs (in Japanese) 
KOBE MARINE OBSERVATORY (1932): The results of the oceanographical observations on board R. M. S. "Syunpa-maru" in the principal part of the Japan Sea in the summer of 1930. Kaiyô-zihô, Vol. 4, No. 1, pp. 1-173.

Koкubo, S. (1926): The plankton of the Tugaru Strait. Proc. Pan-Pacific. Sci. Congress Tokyo, pp. 289-295.

KomAI, T. (1932): On some salpas occurring in the vicinity of Seto, with remarks on the enantiomorphism found in some aggregated forms. Mem. Coll. Sci. Kyôto Imp. Univ., Ser. B, Vol. 8, No. 1, pp. 65-80, 8 text-figs.

Krüger, H. (1939): Die Thaliaceen der "Meteor"-Expedition. D. A. E. "Meteor" 1925/27, Bd. 13, No. 2, pp. 111-152.

LaNGerhans, P. (1880): Ueber Madeiras Appendicularien. Zeit. f. wiss. Zool., Bd. 34, pp. 144146.

LohmanN, H. (1896a): Zoologische Ergebnisse der von der Gesellschaft für Erdkunde zu Berlin unter Leitung Dr. vON DRYGALSKI's ausgesandten Grönlandexpedition nach VANHÖFFEN's Sammlungen bearbeitet. 3. Die Appendicularien der Expedition. Bibliotheca Zoologica, Heft. 20 , pp. 25-44.

(1896b): Die Appendicularien der Plankton-Expedition. Ergebn. Plankton-Exped., Bd. 2 E c, 148 pp., 24 pls.

(1899): Untersuchungen über den Auftrieb der Strasse von Messina mit besonderer Berücksichtigung der Appendicularien und Challengerien. Sitz. kais. Preuss. Akad. Wiss. Berlin, No. 20.

(1905): Die Appendicularien des arktischen und antarktischen Gebiets, ihre Beziehungen zueinander und zu der Arten des Gebiets der warmen Ström. Zool. Jahrb. suppl., Vol. 8, pp. 353-382.

(1909a): Copelata und Thalicea. Die Fauna Südwest-Australiens, Bd. 2, Lief. 10, pp. $143-149,1$ text-fig.

(1909b): Die Strömungen in der Strasse von Messina und die Verteilung des Planktons in derselben. Internat. Rev. gesam. Hydrobiol. Hydrograph., Bd. 2, pp. 505-556.

(1914a): Die Appendicularien der Valdivia-Expedition. Verhandl. Deutsch. Zool.

Gesellschaft, 1914, pp. 157-192, 11 text-figs.

(1914b): Die Appendicularien gattung Megalocercus, zugleich ein Beitrag zu den biologischen Ergeonissen der Ausfahrt der "Deutschland" 1911. Mitt. Naturhist. Mus. Hamburg, Jahrg. 31, pp. 353-366.

(1916): Ergebnisse einer zoologischen Forschungsreise nach Westindien. Die Appendicularien. Zool. Jahrb., suppl., Bd. 11, pp. 343-350.

(1928): Beiträge zur Planktonbevölkerung der Weddellsee nach den Ergebnissen der Deutschen Antarktischen Expedition 1911-1912. Die Appendicularien-Bevölkerung der Weddellsee. Internat. Rev. gesam. Hydrobiol. Hydrograph., Bd. 20, pp. 13-72.

(1931): Die Appendicularien der Deutschen Tiefsee-Expedition. Deutsch. TiefseeExped., Bd. 21, Hft. 1.

(1933): Tunicata-Appendicularien in Kükenthal \& Krumbach : Handb. d. Zool., Bd. 5, 2 Hälfte, Lief. 2, pp. 166-180 (the part concerning the distribution), text-fig. 142.

LoHmanN, H. \& BüCKMANN, AD. (1926): Gie Appendicularien der Deutschen Südpolar-Expedition 1901-03. Ergebn. Deutsch. Südpol.-Exped., Bd. 18 (Zool. Bd. 10), pp. 63-231, 55 text-figs.

Lohmann, H. \& Hentschel, E. (1939): Die Appendicularien im Südatlantischen Ozean. D.A.E. "Meteor" 1925/27, Bd. 13, No. 3, pp. 153-243.

Massuti, M. (1959): Estudio de los taliáceos del plancton de Castellón durante el año 1954. Invest. Pesq., Barcelona, Tom. 14, pp. 53-63, 5 text-figs.

Metcalf, M. M. (1918): The Salpidae, a taxonomic study. Bull. U. S. Nat. Mus. Bull. 100, Vol. 2, part 2, 193 pp., 150 text-figs., 14 pls. 
Motoda, S. \& ANRaku, M. (1951): Plankton material of 1950. Reports of the deep sea fishing ground surveys in the northern Japan Sea, No. 2, pp. 105-107, 1 text-fig. (in Japanese)

Moure, J. S., BJörnberg, T. K. S. \& Loureiro, T. ST. (1954) : Protochordata ocorrentes na entroda da Baia de Paranagua. Dusenia, Vol. 5, Nos. 5-6, pp. 233-242.

Negrea, St., Negrea, A. \& Elian, L. (1959): Observations sur la répartition du zooplancton sur le profil est-Constantza. Univ. "Al. I. Cuza" Iasi, Trav. Sess. Sci. Stat. Zool. Mar., 1959, pp. $9-24,6$ pls.

Neumann, G. (1906) : Doliolum. Wiss. Ergebn. Deutsch. Tiefsee-Exped., Bd. 12, No. 2, pp. 93243, pls. 11-25.

(1913): Die Pyrosomen und Dolioliden der Deutschen Sudpolar-Expedition 19011903. Ergebn. Deutsch. Suidp.-Exped., Bd. 14 (Zool. 6), pp. 1-34, pls. 1-3.

(1935): Cyclomyaria in Kưkenthal \& Krumbach: Handb. Zool., Bd. 5, 2 Hälfte, 4 Lief., pp. 324-400, text-figs. 251-305.

Nikitin, V. (1929): La distribution verticale du planction dans la Mer Noir. 2. Zooplancton (les Copépodes et les Cladocéres exceptés). Trav. Stat. Biol. Sébastopol, Tom. 1.

Oceanographical Section of Japan Meteorological Agency (1960): Report of the oceanographic observations in the sea east of Honshu from May to June, 1959. The Results of Marine Meteorological and Oceanographical Observations, No. 25, p. 26, text-fig. 3-3 (part concerning Doliolum).

OKA, A. (1913): Salpas of Japan. Gendai-no-Kwagaku, Vol. 1, pp. 309-314, 401-404. (in Japanese)

- (1915): Report upon the Tunicata in the collection of the Indian Museum. Mem. Indian Mus., Vol. 6, pp. 29-32.

(1921): Ueber Traustedtia multitentaculata (QUOY \& GAIMARD), eine seltene Salpe. Annot. Zool. Japon., Vol. 10, Part 1, pp. 1-14, 5 text-figs.

RITTER, WM. E. (1905): The pelagic Tunicata of the San Diego Region, excepting the Larvacea. Univ. Calif. Publ. Zool., Vol. 2.

(1906): Cyclosalpa retracta, a new salpoid from the coast of Japan. Annot. Zool. Japon., Vol. 6, pp. 1-5, 2 text-figs.

RitTer, WM. \& Byxbee, E. S. (1905): The pelagic Tunicata. Mem. Mus. Comp. Zool. Harvard Coll., Vol. 26, No. 5 .

Russell, F. S. \& HASTINGS, A. B. (1933): On the occurrence of pelagic tunicates (Thaliacea) in the waters of the English Channel off Plymouth. J. Mar. biol. Ass. U. K., Vol. 18, No. 2, pp. 635-640.

Russell, F. S. \& Colman, J. S. (1935): The Zooplankton. 4. The occurrence and seasonal distribution of the Tunicata, Mollusca and Coelenterata (Siphonophora). Great Barrier Reef Exped. 1928-29, Sci. Rep., Vol. 2, pp. 205-234, 12 text-figs.

SEwEll, R. B. S. (1926): The salps of Indian seas. Rec. Indian Mus., Vol. 28, pp. 65-126, 43 text-fig.

(1953): The pelagic Tunicata. John Murray Exped. 1933-34, Sci. Rep., Vol. 10, No. 1 , pp. $1-90,1$ pl., 32 text-figs.

Sisido, I. (1899): Key to the species of Doliolum. Zool. Mag., Tokyo, Vol. 11, pp. 279-280.

Thompson, H. (1948): Pelagic tunicates of Australia. 196 pp. 75 pls., 19 text-figs., Melbourne. (1954): Pelagic tunicates. B. A. N. Z. Antarctic Research Exped. 1929-31, Rep.

Ser. B, Vol. 1, Part 4, pp. 183-185.

TokiokA, T. (1937): Notes on salpas and doliolums occurring on the Pacific coast of middle Japan. Annot. Zool. Japan., Vol. 16, No. 3, pp. 219-232, pls. 13-14, 1 text-fig. (1938a): On the aggregated form of the rare salpa, Traustedtia multitentaculata

(QuoY \& GaImARD). Annot. Zool. Japon., Vol. 17, Nos. 3-4, pp. 234-243, pl. 14, 7 text-figs. (1938b): Thaliacea. Fauna Nipponica, Vol. 14, Fasc. 2, No. 1, 100 pp., 76 textfigs. (in Japanese)

(1939): Observations on chaetognaths and pelagic tunicates in Osaka Bay. Umi to Sora (Sea and Sky), Vol. 19, No. 6, pp. 152-160, 2 text-figs. (in Japanese) 
(1940): Some additional notes on the Japanese appendicularian fauna. Rec.

Oceanogr. Works in Japan, Vol. 11, No. 1, pp. 1-26, 22 text-figs.

- (1942): Systematic studies of the plankton organisms occurring in Iwayama Bay,

Palao. 7. A preliminary report on the appendicularian fauna of the bay and the adjacent waters. Palao Trop. Biol. Stat. Stud., Vol. 2, No. 3, pp. 613-616.

(1950): Droplets from the Plankton Net. 6. Notes on the posterior protuberances

found in some fritillarians. Publ. Seto Mar. Biol. Lab., Vol. 1, No. 3, pp. 153-155, text-figs. $7-8$.

(1951a): Droplets from the Plankton Net. 9. Record of Cyclosalpa bakeri from Japanese waters. Ibid., Vol. 1, No. 4, p. 183.

(1951b): Pelagic tunicates and chaetognaths collected during the cruises to the New Yamato Bank in the Sea of Japan. Ibid., Vol. 2, No. 1, pp. 1-25, 12 text-figs. (1954): Descriptions on the aggregated form of Brooksia rostrata (TRAUSTEDT), an insufficiently known salpa. Ibid., Vol, 4, No. 1, pp. 148-153, pls. 9-10, 4 text-figs. (1955a): General consideration on Japanese appendicularian fauna. Ibid., Vol. 4, Nos. 2-3, pp. 251-261, 6 text-figs.

(1955b): Droplets from the Plankton Net. 17. A small collection of chaetognaths and pelagic tunicates from the north-eastern part of the Indian Ocean. Ibid., Vol. 5, No. 1, pp. 75-78, text-figs. 19-21.

(1955c): Droplets from the Plankton Net. 18. Short notes on a few appendicularians collected in the "Kurosio" off Siono-misaki. Ibid., Vol. 5, No. 1, pp. 78-80 text-figs. 22-23. (1955d): On some plankton animals collected by the Syunkotu-maru in May-June

1954. Bull. Biogeogr. Soc. Japan, Vols. 16-19, pp. 251-255, 3 text-figs.

(1956a): On chaetognaths and appendicularians collected in the central part of the Indian Ocean. Publ. Seto Mar. Biol. Lab., Vol. 5, No. 2, pp. 197-202.

(1956b): On chaetognaths and appendicularians collected by Mr. Z. SAGARA in the Arafura Sea in May-August 1955. Ibid., Vol. 5, No. 2, pp. 203-208.

(1956c): Fritillaria arafoera n. sp., a form of the sibling species: Fritillaria

haplostoma-complex (Appendicularia: Chordata). Pacific Science, Vol. 10, No. 4, pp. 403-406, 1 text-fig.

(1957): Two new appendicularians from the eastern Pacific, with notes on the morphology of Fritillaria aequatorials and Tectillaria fertilis. Trans. American Microscop. Soc., Vol. 76, No. 4, pp. 359-365, 4 text-figs.

(1958): Further notes on some appendicularians from the Eastern Pacific. Publ. Seto Mar. Biol. Lab., Vol. 7, No. 1, pp. 1-17, 10 text-figs.

(1959): Observations on the taxonomy and distribution of chaetognaths of the North Pacific. Ibid., Vol. 7, No. 3, pp. 349-456, 35 text-figs.

(1960): Droplets from the Plankton Net. 19. A glimpse upon chaetognaths and pelagic tunicates collected in the lagoon water near Noumea, New Caledonia. Ibid., Vol. 8, No. 1, pp. 51-53.

TokiokA, T. \& Berner, Leo (1958a): Two new doliolids from the eastern Pacific Ocean. Pacific Science, Vol. 12, No. 2, pp. 135-138, 2 text-figs.

\& (1958b): On certain Thaliacea (Tunicata) from the Pacific Ocean, with descriptions of two new species of doliolids. Pacific Science, Vol. 12, No. 4, pp. 317-326, 9 text-figs.

Tokioka, T. \& Suárez, J. A. (1956): Appendicularias de los mares Cubanos. Mem. Soc. Cubana Hist. Nat., Vol. 23, No. 1, pp. 37-80, 15 pls., 9 text-figs.

UDVARDy, M. D. F. (1958): Appendicularia in Further Zool. Res. Swedish Antarc. Exped. 190103, Vol. 5, No. 1, 15 pp., 9 text-figs.

UEBEL, E. (1913): Oikopleura najadis nov. spec., eine neue Appendicularia aus der Adria. Zool. Anz., Bd. 41, pp. 626-629. 
UlJANIN, B. (1884): Die Arten der Gattung Doliolum im Golfe von Neapel und angrenzenden Meeresabschnitten. Fauna u. Flora d. Golfes v. Neapel, Monogr. 10, 140 pp., 12 pls.

Verniēeres, P. (1933): Essai sur l'histoire naturelle des appendiculaires de Banyuls et de Sète. Bull. Inst. Océanogr. Monaco, No. 617, 60 pp., 1 pl., 28 text-figs.

(1934): Les appendiculaires de la mer de Villefranche: Pegalopleura haranti n. sp. Bull. Soc. Zool. France, Tom. 59.

YAMADA, T. (1933): Report on the distribution of the plankton in the neighbouring seas of Tyôsen in June 1932. Appendix to Ann. Rep. Hydrograph. Observ., No. 7, 10 pp., 2 pls., 16 charts. (in Japanese)

Yount, J. L. (1954): The taxonomy of the Salpidae (Tunicata) of the Central Pacific Ocean. Pacific Science, Vol. 8, pp. 276-330, 30 text-figs.

(1958): Distribution and ecologic aspects of Central Pacific Salpidae (Tunicata). Ibid. Vol. 12, No. 2, pp. 111 130, 6 text-figs.

ZYL, R. P. VAN (1960): A preliminary study of the salps and doliolids off the West and South coasts of South Africa. Invest. Rep., Univ. South Africa, No. 40, 31 pp., 4 pls., 8 textfigs.

\section{SUPPLEMENT}

After the manuscript of the present paper was sent out to be printed, three more papers on pelagic tunicates were published and two other important papers were found overlooked. They are :

(1) Furnestin, M. L. (1960): Zooplancton du Golfe du Lion et de la cote orientale de Corse. Rev. Trav. Inst. Pêches marit., Vol. 24, No. 2, pp. 153-252.

Descriptions about pelagic tunicates are given on pp. 160 and 202-203. Oikopleura longicauda and Thalia democratica were the commonest forms in the surveyed area. Two doliolums were recorded, Doliolum denticulatum was met with only exceptionally, while Doliolum nationalis was found commonly in the Gulf of Lion in the range affected by the Rhone, but quite absent in the offshore water out of the southern border of the gulf and in the waters off the eastern coast of Corsica.

(2) BERNER, L. D. (1960): Unusual features in the distribution of pelagic tunicates in 1957 and 1958. California Cooperative Oceanic Fisheries Investigations Reports, Vol. 7, pp. 133-135.

Occurrences of Dolioletta gegenbauri and Doliolum denticulatum in the coastal water off Lower California are mentioned. The former is considered as an indicator of the California Current or subarctic water, while the latter is treated as that of the Central or sub-tropical water.

(3) DeEveY, G. B. (1960): The zooplankton of the surface waters of the Delaware Bay region. Bull. Bingham Oceanogr. Collection, Vol. 17, pp. 5-53.

The occurrence of pelagic tunicates is mentioned on pp. 36-37. Oikopleura longicauda, $O$. dioica, $O$. labradoriensis and Fritillaria borealis appeared in the bay and did also Doliolum nationalis, Dolioletta gegenbauri, Salpa fusiformis and Thalia democratica. Among these, O. dioica and $D$. nationalis were the two tunicates which appeared regularly each summer or fall, usually during the same period. This seems to show evidently the occurrence of $D$. nationalis in the inshore waters.

(4) KADO, Y. (1954): The seasonal change of plankton and Hydrography of the neighbouring sea of Mukaishima. Jour. Sci. Hiroshima Univ., Ser. B, Div. 1, Vol. 15, Art. 6, pp. 193-204.

Mukaishima is located slightly west to the middle part of the Inland Sea. Oikopleura dioica was the commonest form of all pelagic tunicates. Besides, Fritillaria haplostoma occurred in August-November, 1949, Dolioletta gegenbauri var. tritonis made an unexpectedly sudden appearance on Dec. 7, 1949 and Salpa fusiformis on June 21, 1949.

(5) Furnestin, M. L. (1957): Chaetognathes et zooplancton du secteur atlantique Morocain. Rev. Trav. Inst. Pêches marit., Vol. 21, Nos. 1-2, pp. 1-356.

Occurrences of appendicularians are recorded on pp. 51 and 93-108. In this friderici-water, Oikopleura dioica occupied the greatest part $(70 \%)$ of the appendicularian fauna and next Oikopleura longicauda $(24.2 \%)$ 


\section{STATION DATA}

1. Station data for the sampling stations in the neighbouring waters of the Palao Islands.

\begin{tabular}{cl} 
Station Number & \multicolumn{1}{c}{ Position } \\
14 & $8^{\circ} 00^{\prime} \mathrm{N} \times 134^{\circ} 45^{\prime} \mathrm{E}$ \\
15 & $8^{\circ} 10^{\prime} \mathrm{N} \times 134^{\circ} 45^{\prime} \mathrm{E}$ \\
17 & $7^{\circ} 01^{\prime} \mathrm{N} \times 134^{\circ} 27.0^{\prime} \mathrm{E}$ \\
18 & $6^{\circ} 52^{\prime} \mathrm{N} \times 134^{\circ} 20.3^{\prime} \mathrm{E}$ \\
19 & $6^{\circ} 48.5^{\prime} \mathrm{N} \times 134^{\circ} 10.4^{\prime} \mathrm{E}$ \\
20 & $6^{\circ} 45.3^{\prime} \mathrm{N} \times 134^{\circ} 07.4^{\prime} \mathrm{E}$ \\
21 & $7^{\circ} 05.9^{\prime} \mathrm{N} \times 134^{\circ} 08.0^{\prime} \mathrm{E}$ \\
22 & $7^{\circ} 03.1^{\prime} \mathrm{N} \times 134^{\circ} 06.8^{\prime} \mathrm{E}$ \\
23 & $7^{\circ} 18.2^{\prime} \mathrm{N} \times 134^{\circ} 07.7^{\prime} \mathrm{E}$ \\
24 & $7^{\circ} 17.7^{\prime} \mathrm{N} \times 134^{\circ} 05.4^{\prime} \mathrm{E}$ \\
25 & $7^{\circ} 32.6^{\prime} \mathrm{N} \times 134^{\circ} 18.8^{\prime} \mathrm{E}$ \\
26 & $7^{\circ} 35.0^{\prime} \mathrm{N} \times 134^{\circ} 20.6^{\prime} \mathrm{E}$ \\
27 & $7^{\circ} 44.2^{\prime} \mathrm{N} \times 134^{\circ} 27.0^{\prime} \mathrm{E}$ \\
28 & $7^{\circ} 47.8^{\prime} \mathrm{N} \times 134^{\circ} 26.7^{\prime} \mathrm{E}$ \\
29 & $8^{\circ} 04.0^{\prime} \mathrm{N} \times 134^{\circ} 36.2^{\prime} \mathrm{E}$ \\
30 & $8^{\circ} 03.2^{\prime} \mathrm{N} \times 134^{\circ} 32.5^{\prime} \mathrm{E}$ \\
31 & $8^{\circ} 03.4^{\prime} \mathrm{N} \times 134^{\circ} 47.8^{\prime} \mathrm{E}$ \\
32 & $8^{\circ} 06.3^{\prime} \mathrm{N} \times 134^{\circ} 45.5^{\prime} \mathrm{E}$ \\
33 & $7^{\circ} 30.7^{\prime} \mathrm{N} \times 134^{\circ} 47.2^{\prime} \mathrm{E}$ \\
34 & $7^{\circ} 30.8^{\prime} \mathrm{N} \times 134^{\circ} 46.0^{\prime} \mathrm{E}$ \\
35 & $7^{\circ} 15.7^{\prime} \mathrm{N} \times 134^{\circ} 47.0^{\prime} \mathrm{E}$ \\
36 & $7^{\circ} 14.0^{\prime} \mathrm{N} \times 134^{\circ} 45.8^{\prime} \mathrm{E}$ \\
59 & $5^{\circ} 30^{\prime} \mathrm{N} \times 136^{\circ} 20^{\prime} \mathrm{E}$ \\
60 & $5^{\circ} 30^{\prime} \mathrm{N} \times 136^{\circ} 19^{\prime} \mathrm{E}$ \\
61 & $6^{\circ} 22^{\prime} \mathrm{N} \times 136^{\circ} 14^{\prime} \mathrm{E}$ \\
62 & $6^{\circ} 35^{\prime} \mathrm{N} \times 136^{\circ} 07^{\prime} \mathrm{E}$ \\
63 & $6^{\circ} 25^{\prime} \mathrm{N} \times 137^{\circ} 28^{\prime} \mathrm{E}$ \\
64 & $6^{\circ} 26.5^{\prime} \mathrm{N} \times 137^{\circ} 21.5^{\prime} \mathrm{E}$ \\
65 & $7^{\circ} 30.5^{\prime} \mathrm{N} \times 137^{\circ} 29^{\prime} \mathrm{E}$ \\
66 & $7^{\circ} 31^{\prime} \mathrm{N} \times 137^{\circ} 27.5^{\prime} \mathrm{E}$ \\
67 & $7^{\circ} 30^{\prime} \mathrm{N} \times 136^{\circ} 26.5^{\prime} \mathrm{E}$ \\
68 & $7^{\circ} 30^{\prime} \mathrm{N} \times 136^{\circ} 23^{\prime} \mathrm{E}$ \\
69 & $8^{\circ} 46^{\prime} \mathrm{N} \times 136^{\circ} 29.7^{\prime} \mathrm{E}$ \\
$8^{\circ} 42^{\prime} \mathrm{N} \times 136^{\circ} 26^{\prime} \mathrm{E}$ \\
$8^{\circ} 39^{\prime} \mathrm{N} \times 135^{\circ} 20.5^{\prime} \mathrm{E}$ \\
$8^{\circ} 43^{\prime} \mathrm{N} \times 135^{\circ} 14^{\prime} \mathrm{E}$ \\
\end{tabular}

\begin{tabular}{|c|c|c|}
\hline & Data & $\begin{array}{l}\text { Settling volume } \\
\text { of plankton }\end{array}$ \\
\hline \multirow{2}{*}{\multicolumn{2}{|c|}{$\begin{array}{c}\text { Oct. } 15,1939 \\
"\end{array}$}} & $6.3 \mathrm{cc}$ \\
\hline & & 2.7 \\
\hline \multirow{2}{*}{\multicolumn{2}{|c|}{$\begin{array}{c}\text { Apr. } 9,1940 \\
,\end{array}$}} & 1.2 \\
\hline & & 1.1 \\
\hline \multicolumn{2}{|r|}{10} & 1.0 \\
\hline \multirow{2}{*}{\multicolumn{2}{|c|}{ "', }} & 0.7 \\
\hline & & 1.8 \\
\hline \multicolumn{2}{|r|}{$"$} & 3,8 \\
\hline \multicolumn{2}{|r|}{12} & 2.4 \\
\hline & $"$ & 1.3 \\
\hline \multicolumn{2}{|r|}{13} & 1.3 \\
\hline & $"$ & 1.4 \\
\hline \multicolumn{2}{|r|}{14} & 2.5 \\
\hline \multirow{2}{*}{\multicolumn{2}{|c|}{$"$}} & 1.4 \\
\hline & & 1.5 \\
\hline \multirow{2}{*}{\multicolumn{2}{|c|}{$\ddot{16}$}} & 2.6 \\
\hline & & 1.3 \\
\hline \multirow{2}{*}{\multicolumn{2}{|c|}{$" 17$}} & 1.2 \\
\hline & & 1.4 \\
\hline \multirow{2}{*}{\multicolumn{2}{|c|}{$\ddot{18}$}} & 1.2 \\
\hline & & 2.2 \\
\hline & " & 0.8 \\
\hline \multirow[t]{14}{*}{ Jan. } & 16,1940 & 0.3 \\
\hline & $"$ & 0.4 \\
\hline & 17 & 0.3 \\
\hline & $"$ & 0.6 \\
\hline & 18 & 0.6 \\
\hline & $"$ & 0.9 \\
\hline & 19 & 0.7 \\
\hline & $"$ & 0.8 \\
\hline & 20 & 0.2 \\
\hline & $"$ & 0.5 \\
\hline & 21 & 0.3 \\
\hline & $"$ & 0.3 \\
\hline & 22 & $0.1-$ \\
\hline & $"$ & 0.4 \\
\hline
\end{tabular}


Distribution of Appendicularians and Some Thaliaceans of the North Pacific 439

\begin{tabular}{|c|c|c|c|}
\hline Station Number & Position & Data & $\begin{array}{l}\text { Settling volume } \\
\text { of plankton }\end{array}$ \\
\hline 73 & $7^{\circ} 43^{\prime} \mathrm{N} \times 135^{\circ} 24^{\prime} \mathrm{E}$ & Jan. 23, 1940 & $0.25 \mathrm{cc}$ \\
\hline 74 & $7^{\circ} 51^{\prime} \mathrm{N} \times 135^{\circ} 23^{\prime} \mathrm{E}$ & , & 0.3 \\
\hline 75 & $5^{\circ} 38^{\prime} \mathrm{N} \times 131^{\circ} 40 \mathrm{E}$ & Feb. 5, & 0.2 \\
\hline 76 & $5^{\circ} 41^{\prime} \mathrm{N} \times 131^{\circ} 43^{\prime} \mathrm{E}$ & $"$ & $0.1-$ \\
\hline 77 & $4^{\circ} 30^{\prime} \mathrm{N} \times 131^{\circ} 40^{\prime} \mathrm{E}$ & 6 , & 2.5 \\
\hline 78 & $4^{\circ} 27^{\prime} \mathrm{N} \times 132^{\circ} 05^{\prime} \mathrm{E}$ & $"$ & 3.8 \\
\hline 79 & $3^{\circ} 24^{\prime} \mathrm{N} \times 131^{\circ} 40^{\prime} \mathrm{E}$ & 7 & 4.7 \\
\hline 80 & $3^{\circ} 23^{\prime} \mathrm{N} \times 132^{\circ} 05^{\prime} \mathrm{E}$ & , & 7.9 \\
\hline 81 & $2^{\circ} 08^{\prime} \mathrm{N} \times 131^{\circ} 30^{\prime} \mathrm{E}$ & 8 & 6.9 \\
\hline 82 & $2^{\circ} 02^{\prime} \mathrm{N} \times 131^{\circ} 30.5^{\prime} \mathrm{E}$ & , & 6.2 \\
\hline 83 & $3^{\circ} 08^{\prime} \mathrm{N} \times 132^{\circ} 40^{\prime} \mathrm{E}$ & 9 & 6.9 \\
\hline 84 & $3^{\circ} 09.5^{\prime} \mathrm{N} \times 133^{\circ} 01^{\prime} \mathrm{E}$ & , & 9.2 \\
\hline 85 & $4^{\circ} 22^{\prime} \mathrm{N} \times 133^{\circ} 58^{\prime} \mathrm{E}$ & 10 , & 3.4 \\
\hline 86 & $4^{\circ} 12^{\prime} \mathrm{N} \times 134^{\circ} 10^{\prime} \mathrm{E}$ & $"$ & 5.4 \\
\hline
\end{tabular}

2. Station datum for a sampling station during the Palao-New Guinea Cruise, March 1940
1
$6^{\circ} 58^{\prime} \mathrm{N} \times 134^{\circ} 29^{\prime} \mathrm{E}$
Mar. 17, 1940
$0.8 \mathrm{cc}$

3. Station data for the samples collected by the Syunpû-maru in the Japan Sea and the Tugaru Straits in 1930

\begin{tabular}{cl} 
Station Number & \multicolumn{1}{c}{ Position } \\
7 & $37^{\circ} 01^{\prime} \mathrm{N} \times 131^{\circ} 13^{\prime} 30^{\prime \prime} \mathrm{E}$ \\
9 & $37^{\circ} 41^{\prime} \mathrm{N} \times 130^{\circ} 21^{\prime} \mathrm{E}$ \\
10 & $37^{\circ} 59^{\prime} \mathrm{N} \times 129^{\circ} 51^{\prime} \mathrm{E}$ \\
11 & $38^{\circ} 16^{\prime} \mathrm{N} \times 129^{\circ} 22^{\prime} \mathrm{E}$ \\
12 & $38^{\circ} 34^{\prime} \mathrm{N} \times 128^{\circ} 52^{\prime} 30^{\prime \prime} \mathrm{E}$ \\
13 & $38^{\circ} 54^{\prime} \mathrm{N} \times 128^{\circ} 20^{\prime} \mathrm{E}$ \\
14 & $39^{\circ} 13^{\prime} \mathrm{N} \times 128^{\circ} 00^{\prime} \mathrm{E}$ \\
26 & $40^{\circ} 48^{\prime} 50^{\prime \prime} \mathrm{N} \times 129^{\circ} 47^{\prime} 40^{\prime \prime} \mathrm{E}$ \\
27 & $41^{\circ} 14^{\prime} 20^{\prime \prime} \mathrm{N} \times 129^{\circ} 48^{\prime} 05^{\prime \prime} \mathrm{E}$ \\
36 & $40^{\circ} 50^{\prime} \mathrm{N} \times 132^{\circ} 05^{\prime} \mathrm{E}$ \\
37 & $40^{\circ} 12^{\prime} \mathrm{N} \times 132^{\circ} 48^{\prime} 20^{\prime \prime} \mathrm{E}$ \\
56 & $38^{\circ} 25^{\prime} \mathrm{N} \times 138^{\circ} 32^{\prime} \mathrm{E}$ \\
57 & $37^{\circ} 21^{\prime} 45^{\prime \prime} \mathrm{N} \times 138^{\circ} 33^{\prime} 30^{\prime \prime} \mathrm{E}$ \\
58 & $38^{\circ} 14^{\prime} 30^{\prime \prime} \mathrm{N} \times 138^{\circ} 41^{\prime} 30^{\prime \prime} \mathrm{E}$ \\
64 & $38^{\circ} 35^{\prime} \mathrm{N} \times 138^{\circ} 51^{\prime} \mathrm{E}$ \\
65 & $38^{\circ} 52^{\prime} 50^{\prime \prime} \mathrm{N} \times 139^{\circ} 00^{\prime} \mathrm{E}$ \\
68 & $40^{\circ} 02^{\prime} 30^{\prime \prime} \mathrm{N} \times 139^{\circ} 36^{\prime} 30^{\prime \prime} \mathrm{E}$ \\
69 & $40^{\circ} 18^{\prime} 30^{\prime \prime} \mathrm{N} \times 139^{\circ} 42^{\prime} \mathrm{E}$
\end{tabular}

Date

July 3, 1930

$\left.\begin{array}{l}" \\ 4,\end{array}\right\}$

" $\quad 50-0$

13 ,

,

23 ,

"

Aug. 7,

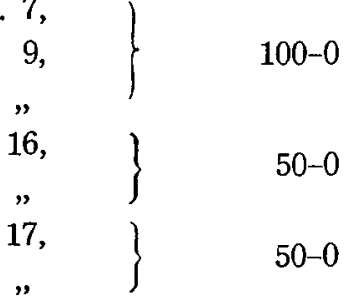

Haul Distance

40-0 m

50-0

50-0

$100-0$

$100-0$ 


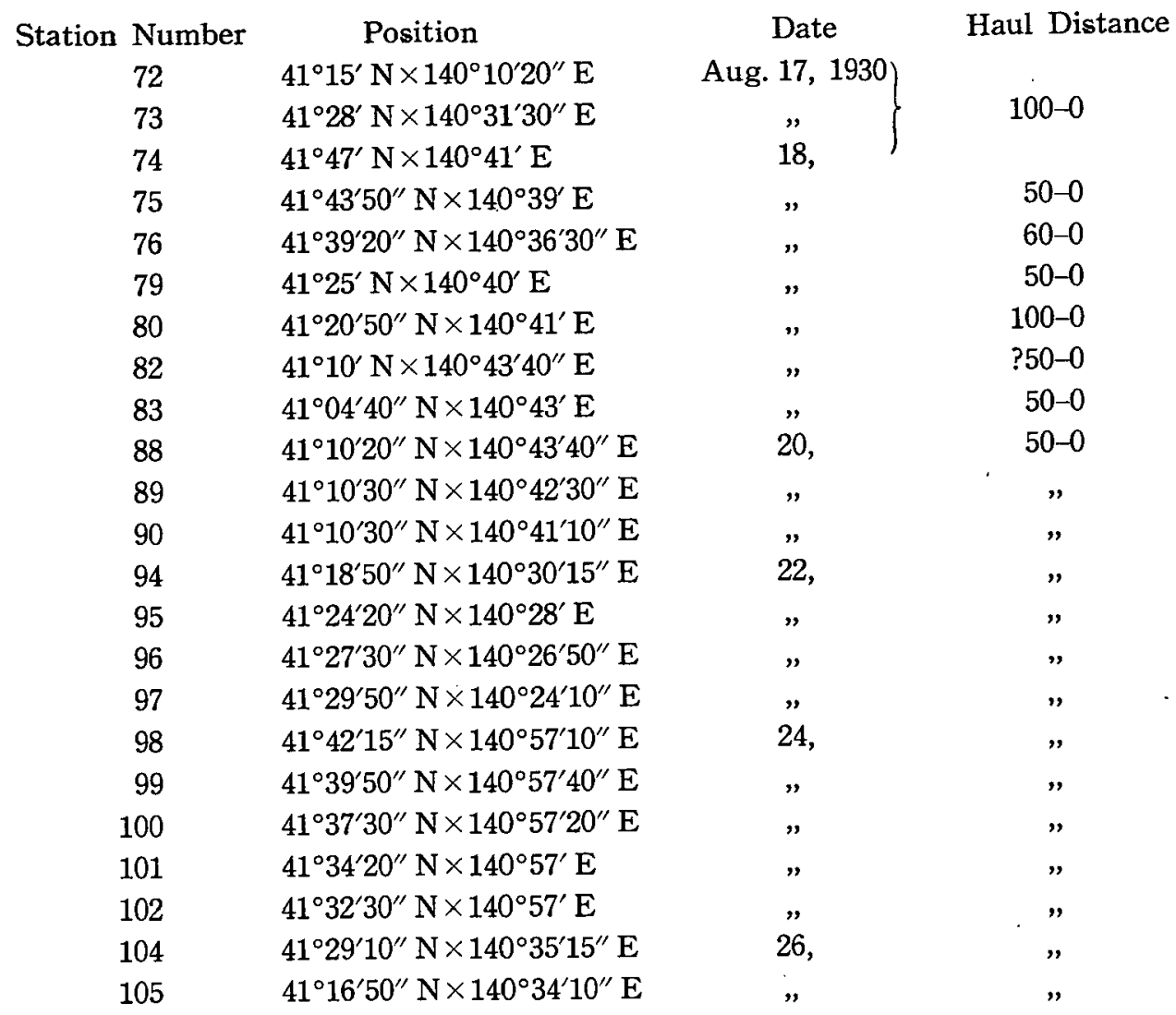




\section{INDEX}

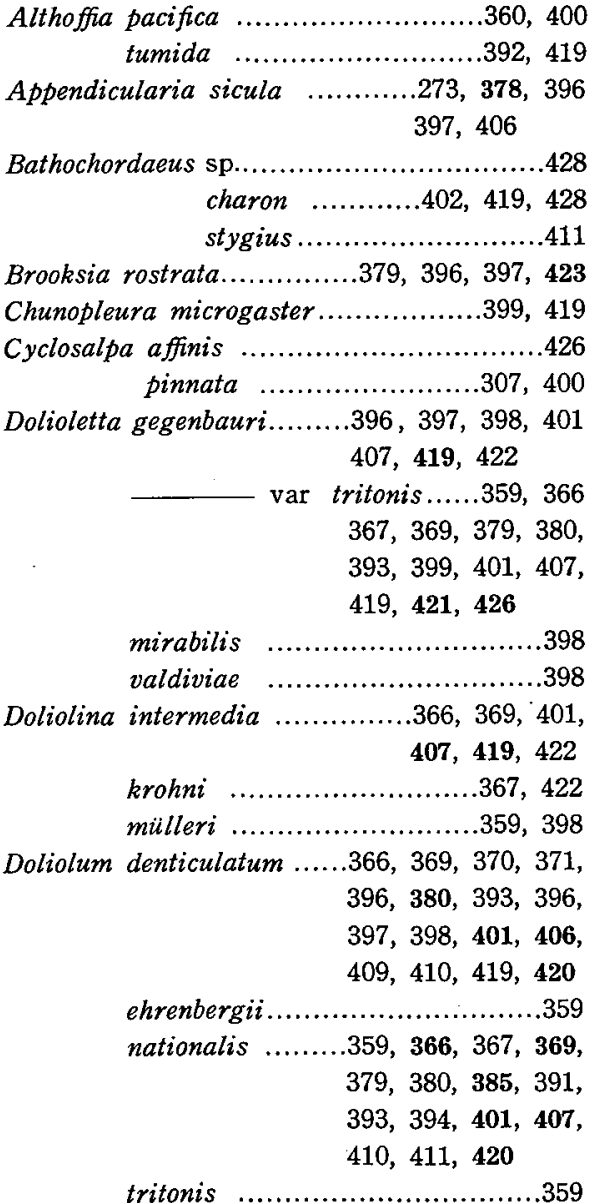

Doliopsoides.... .422

Folia gracilis...........................414, 419

Fritillaria aberrans .....................416, 419 abjornseni.........360, 361, 401, 402 aequatorials ................402, 419 amygdala..........................360

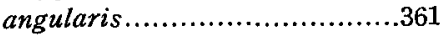
aplostoma.........................408

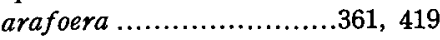
artus................................361 bicornis ...........................398 borealis ...............360, 361, 406 —_ acuta .....................362

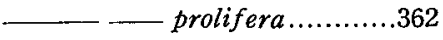

Frit.

f. allongata .362

crassa ...............410

f. intermedia ...360, 362, $363,406,409$ f. ritteri .................362

f. sargassi........... 359, $361,363,366,368$, $369,370,373, \mathbf{3 7 7}$, $380,393,394,397$, $398,399,400,405$, $410,411,415,419$, 429

f. typica..........356, 358, 350,363

troncata elongata ......409 truncata .................362

- allongata ......362

- crassa .........362

intermedia ...362

ritteri .........362

_ sargassi ......362

var. allongata...........362

var. mediterranea ......410

brevicollis ...........................361

campila .......................360, 400

charybdae .............408, 411, 419

claudaria ............................360

clava.................................361

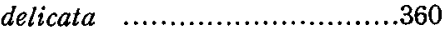

diafana ............................361

dispara..............................361

drygalski ................402, 419

exilis ...............................361

formica ........354, 360, 370, 393,

$399,405,409,410$,

415, 426, 428

f. digitata...366, 369,380 , 396,400

f. tuberculata.....409, 411,

419

fraudax ....................410, 429

furcata ...................402, 408

gigas ............................360

gracilis.........................429

haplostoma ......354, 361, 369, 373, $377,385,393,396$, $397,400,405,414$, 415, 429

helenae $.402,419$ 
Frit.

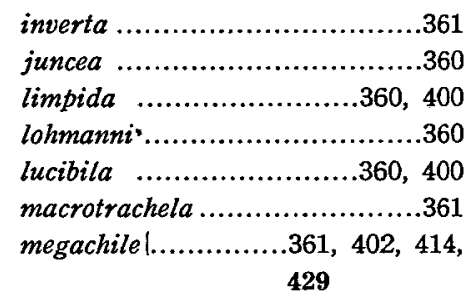

messanensis ......362, 363, 402, 408 nitida ............................361

pacifica............................419

pellucida ........354, 366, 368, 369,

$370,380,385,393$,

$396,397,399,400$,

$405,408,409,410$,

$411,412,415,426$

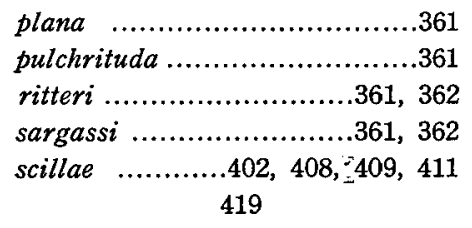

tacita .............................360

tenebra ............................361

tenella ...........368, 369, 385, 411,

$414,415,419,429$

tereta ...............................360

trigonis .............................361

truncata ..........................360

urticans ...................411, 419

velocita.............................361

venusta ...............368, 370, 399,

406,415

Haplopleura (BERRILL 1955).

...Genus name proposed for

Oikopleura longicauda

Iasis zonaria

$368,397,398$,

399,423

Ihlea magalhanica

$.397,398,424$

Kowalewskaia mossi

.408, 419

oceania

tenuis

$408,414,419$

Megalocercus abyssorum.

$.402,410,419$

atlanticus .....................402

diegensis ........................360

huxleyi........368, 369, 370, 385,

$393,394,396,400$,

$415,419,425,427$

Metcalfina hexagona. $.400,423$

Oikopleura albicans $360,364,368,392$, $399,404,410,427$
Oik. californica .......................360

chamissonis ........................356

cophocerca .....359, 364, 368, 369, $380,396,402,404$, $408,409,411,412$, 415,426

dioica ...........358, 360, 364, 368, $373,377,378,385$, $391,393,395,397$, $398,399,400,402$, $404,406,409,410$, $411,412,416,425$, 427, 430

fusiformis .....356, 359, 364, 368, $369,370,373,380$, $385,393,394,395$, $396,398,399,400$, $402,404,405,306$, $409,410,411,412$, $414,415,425$

f. cornutogastra... $373,377,378,379$, $394,396,399,412$, $416,419,425,427$

graciloides .........................368

intermedia ..................410, 425

labradoriensis ........356, 358, 360, 385,406

longicauda ......356, 358, 359, 364, $368,369,370,373$, 377, 378, 380, 384, $385,390,391,393$, $394,395,396,398$, $399,400,402,404$, $405,408,409,410$, $411,412,414,415$, $416,419,425$

magna ...........................402

mediterranea .....................419

najadis ......................408, 426

parva..................399, 404, 408,

414,427

rufescens........364, 368, 369, 370, $373,375,380,385$, $393,394,395,396$, $397,398,399,402$, $411,412,414,415$, $419,425,428$

spissa ............................408

tortugensis .......................411

vanhöffeni .................363, 406 
Distribution of Appendicularians and Some Thaliaceans of the North Pacific 443

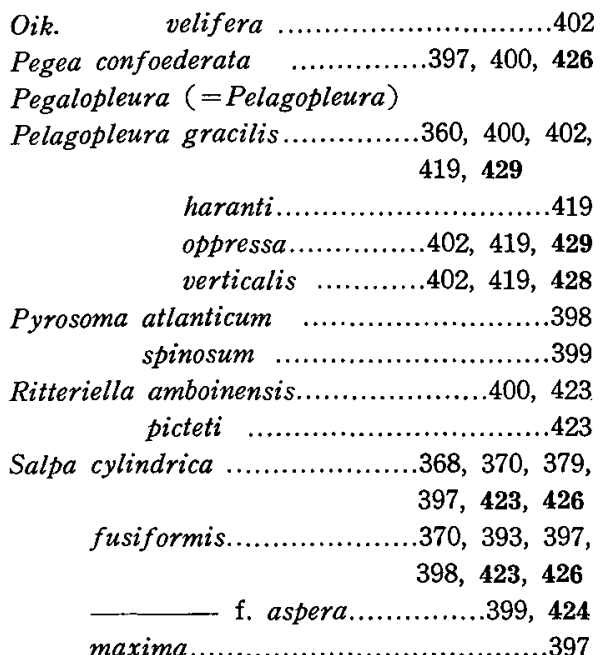

Sinisteroffia scrippsi ..........................419

Stegosoma conogaster.........................398

magnum $\ldots . . . .360,368,369,370$, $396,398,399, \mathbf{4 1 5}$,

428

Tectillaria taeniogona ..................416, 419

Thalia democratica ........368, 369, 370, 371, $379,380,385,391$, $396,397,399,401$, $405,409,410,423$, 426

- var. orientalis .........368, $369,370,371,379$, $380,391,399,401$, $405,410,424,429$

Thetys vagina...................................398

Traustedtia multitentaculata .................397

(For other species see Tables 1 and 34, and also appended tables.) 
1-1

\begin{tabular}{|c|c|c|c|c|c|c|c|c|c|c|c|c|c|c|c|c|c|c|}
\hline Stations & TP 19 & TP 20 & TP 21 & TP 22 & TP 23 & TP 24 & TP 25 & TP 27 & TP 28 & TP 29 & TP 30 & TP 31 & TP 32 & TP 34 & TP 35 & TP 36 & TP 37 & TP 38 \\
\hline Oik. labradoriensis & 27 & 2 & 24 & 11 & 19 & 13 & 299 & 11 & 7 & 26 & 120 & 2 & 3 & 7 & 8 & 69 & 202 & 25 \\
\hline $\begin{array}{l}\text { Oikopleura spp. } \\
\text { Damaged specimens or juv. }\end{array}$ & & 1 & 3 & & 7 & 4 & 16 & & & & 4 & & & 5 & & & 1 & 2 \\
\hline Frit. borealis f. typica & & 1 & 5 & 2 & 7 & & 12 & & 1 & & & & & & & 16 & 1 & \\
\hline Total number & 27 & 4 & 32 & 13 & 33 & 17 & 327 & 11 & 8 & 26 & 124 & 2 & 3 & 12 & 8 & 85 & 204 & 27 \\
\hline
\end{tabular}

$1-2$

\begin{tabular}{|c|c|c|c|c|c|c|c|c|c|c|c|c|c|c|c|c|c|c|}
\hline Stations & TP 39 & $\mathrm{TP} 40$ & TP 41 & TP 42 & TP 43 & TP 44 & TP 45 & TP 46 & $\mathrm{TP} 47$ & TP 48 & TP 49 & $\operatorname{TP} 50$ & TP 63 & TP 64 & TP 65 & ТP 66 & F.O. & $\begin{array}{c}\text { Mean } \\
\text { percentage }\end{array}$ \\
\hline Oik. labradoriensis & 35 & 11 & 10 & 15 & 20 & 129 & 73 & 24 & 75 & 55 & 27 & 39 & 31 & 64 & 29 & 10 & 100 & 83 \\
\hline $\begin{array}{l}\text { Oikopleura spp. } \\
\text { Damaged specimens or juv. }\end{array}$ & 2 & 1 & & 2 & 2 & 8 & 36 & & 4 & 6 & 6 & & & & & & 53 & 13 \\
\hline Frit. borealis f. typica & 2 & & 54 & 119 & 5 & & 4 & & 2 & 16 & 1 & 11 & & & 1 & & 53 & 20 \\
\hline Total number & 39 & 12 & 64 & 136 & 27 & 137 & 113 & 24 & 81 & 77 & 34 & 50 & 31 & 64 & 30 & 10 & & \\
\hline
\end{tabular}

Appendix Table 1 (1-2). Appendicularians found in the Transpac Expedition samples from the subarctic waters.

2

\begin{tabular}{|c|c|c|c|c|c|c|c|c|c|c|c|c|c|c|c|c|c|c|c|c|c|}
\hline Stations & \begin{tabular}{|l|} 
Off San \\
Diego \\
\end{tabular} & \begin{tabular}{|c|c|}
$\begin{array}{c}\text { New Port } \\
\text { Harbor }\end{array}$ \\
\end{tabular} & 1 & $1^{\prime}$ & 2 & 3 & 4 & 5 & 6 & 7 & 8 & 9 & 10 & $10^{\prime}$ & 11 & 12 & 13 & 14 & 15 & F.O. & $\begin{array}{c}\text { Mean } \\
\text { percentage } \\
\end{array}$ \\
\hline Oik. longicauda & 1 & & 17 & 9 & & 2 & 4 & 1 & 1 & 1 & & & 1 & 1 & & & & 64 & 7 & 63 & 1 \\
\hline Oik. fusiformis & & & & & & & & & & & & & & & & & & 1 & & 5 & * \\
\hline Oik. dioica & 698 & 13 & 541 & 670 & 532 & 608 & 581 & 648 & 763 & 887 & 341 & 410 & 579 & 577 & 534 & 687 & 910 & 552 & 641 & 100 & 84 \\
\hline Oik. parva & & & 2 & & & & & 1 & & & & & & & & & & 1 & & 16 & * \\
\hline Oik. labradoriensis & & & & & 2 & 1 & & & & 1. & & 1 & & & & & 1 & 3 & 3 & 37 & * \\
\hline Frit. pellucida & & & & & & & & & & & & & & & & 1 & & 2 & & 11 & * \\
\hline Frit. borealis f. typica & 16 & 1 & 104 & 92 & 84 & 63 & 62 & 79 & 300 & 203 & 57 & 90 & 202 & 331 & 153 & 83 & 182 & 33 & 56 & 100 & 15 \\
\hline Kow. tenuis & & & & & & & & & & & & & $? 1$ & & & & & & & 5 & $*$ \\
\hline Total number & 715 & 14 & 664 & 771 & 618 & 674 & 647 & 729 & 1064 & 1092 & 398 & 501 & 783 & 909 & 687 & 771 & 1093 & 656 & 707 & \multirow{2}{*}{\multicolumn{2}{|c|}{$* \cdots$ less than $0.5 \%$}} \\
\hline Number of species & 3 & 2 & 4 & 3 & 3 & 4 & 3 & 4 & 3 & 4 & 2 & 3 & 4 & 3 & 2 & 3 & 3 & 7 & 4 & & \\
\hline
\end{tabular}




\begin{tabular}{|c|c|c|c|c|c|c|c|c|c|c|c|c|c|c|c|c|c|c|c|}
\hline Stations (01\#) & 1 & 2 & 3 & 4 & 5 & 6 & 7 & 8 & 9 & 10 & 13 & 14 & 15 & 16 & 17 & 18 & 19 & 20 & 21 \\
\hline \multicolumn{20}{|l|}{ Doliolum nationalis } \\
\hline \multicolumn{20}{|l|}{$\begin{array}{l}\text { Dolioletta gegenbauri var. } \\
\text { tritonis }\end{array}$} \\
\hline \multicolumn{20}{|l|}{ Doliolina spp. } \\
\hline Oik. longicauda & 5 & 4 & & & & 1 & 117 & 185 & 112 & 44 & 55 & 40 & 48 & 180 & 23 & 237 & 355 & 50 & 218 \\
\hline Oik. fusiformis & & & & & & & & & & & & & & & & & & & 1 \\
\hline Oik. dioica & 1 & 3 & & 3 & 4 & 5 & 2 & 4 & & 11 & 27 & 16 & 4 & 3 & 5 & 21 & 31 & 7 & 8 \\
\hline $\begin{array}{l}\text { Oikopleura spp. } \\
\text { Damaged specimens or juv. }\end{array}$ & 7 & 27 & 1 & 14 & 15 & 11 & & 31 & 37 & 60 & 60 & 18 & 8 & 21 & 20 & 146 & 167 & 32 & 52 \\
\hline \multicolumn{20}{|l|}{ Frit. abjornseni } \\
\hline Frit. borealis f. typica & & & & & & & & & & & 6 & & & & & 1 & 1 & & $? 1$ \\
\hline $\begin{array}{l}\text { Frit. borealis f. sargassi } \\
\text { Smaller individuals }\end{array}$ & & & & & & & & & & & & & & & & & & & \\
\hline \multicolumn{20}{|l|}{$\begin{array}{l}\text { Fritilllaria spp. } \\
\text { Damaged specimens or juv. }\end{array}$} \\
\hline \multicolumn{20}{|l|}{ App. sicula } \\
\hline Total number & 13 & 34 & 1 & 17 & 19 & 17 & 119 & 220 & 149 & 115 & 148 & 74 & 60 & 204 & 48 & 405 & 554 & 89 & 280 \\
\hline Number of species & 2 & 2 & & 1 & 1 & 2 & 2 & 2 & 1 & 2 & 3 & 2 & 2 & 2 & 2 & 3 & 3 & 2 & 4 \\
\hline
\end{tabular}

\section{$3--2$}

\begin{tabular}{|c|c|c|c|c|c|c|c|c|c|c|c|c|c|c|c|c|c|c|}
\hline Stations (01\%) & 24 & 25 & 26 & 27 & 28 & 29 & 30 & 31 & 32 & 33 & 34 & 35 & 36 & 37 & 38 & 39 & F.O. & \\
\hline Doliolum nationalis & 6 & 2 & 2 & 2 & 31 & 36 & 12 & 2 & & & 1 & & 2 & & & & 29 & \\
\hline $\begin{array}{c}\text { Doliolette gegenbauri var. } \\
\text { tritonis }\end{array}$ & & & & & & 2 & & & & & & & & & & & 3 & \\
\hline Doliolina spp. & & & & & 1 & & & & & & & & 1 & & & & 6 & $\begin{array}{c}\text { Mean } \\
\text { percentage }\end{array}$ \\
\hline Oik. longicauda & 52 & 16 & 23 & 17 & 44 & 15 & 14 & 44 & 31 & 16 & 103 & 41 & 34 & 20 & 8 & 31 & 91 & 45 \\
\hline Oik. fusiformis & 1 & & & & 4 & 1 & 1 & 1 & 1 & & & 17 & 24 & 5 & 10 & 6 & 34 & 4 \\
\hline Oik. dioica & 32 & 17 & 42 & 21 & 12 & 7 & 14 & 30 & 26 & 10 & 73 & 71 & 28 & 34 & 28 & 44 & 94 & 20 \\
\hline $\begin{array}{l}\text { Oikopleura spp. } \\
\text { Damaged specimens or juv. }\end{array}$ & 51 & 14 & 18 & 13 & 21 & $\overline{7}$ & 12 & 17 & 11 & 10 & 38 & 113 & 109 & 53 & 61 & 54 & 97 & 39 \\
\hline Frit. abjornseni & & & & & 3 & & & & & & & & & & & & 3 & 4 \\
\hline Frit. borealis f. typica & 2 & 1 & & & & & & & & & & & & & & & 17 & 1 \\
\hline $\begin{array}{l}\text { Frit. borealis f. sargassi } \\
\text { Smaller individuals }\end{array}$ & & & & & & & & & & & & 8 & 4 & 4 & 2 & 1 & 14 & 2 \\
\hline $\begin{array}{l}\text { Fritillaria spp. } \\
\text { Damaged specimens or juv. }\end{array}$ & & & & & 1 & & & & & & & & & & & & 3 & 1 \\
\hline App. sicula & & & & & & & & & & & & & & 2 & 1 & 1 & 9 & 1 \\
\hline Total number & 138 & 48 & 83 & 51 & 85 & 30 & 41 & 92 & 69 & 36 & 214 & 250 & 199 & 118 & 110 & 137 & & \\
\hline Number of species & 4 & 3 & 2 & 2 & 4 & 3 & 3 & 3 & 3 & 2 & 2 & 4 & 4 & 5 & 5 & 5 & & \\
\hline
\end{tabular}

Appendix Table $3(1-2)$. Pelagic tunicates collected in the waters off San Diego. 


\section{$4-1$}

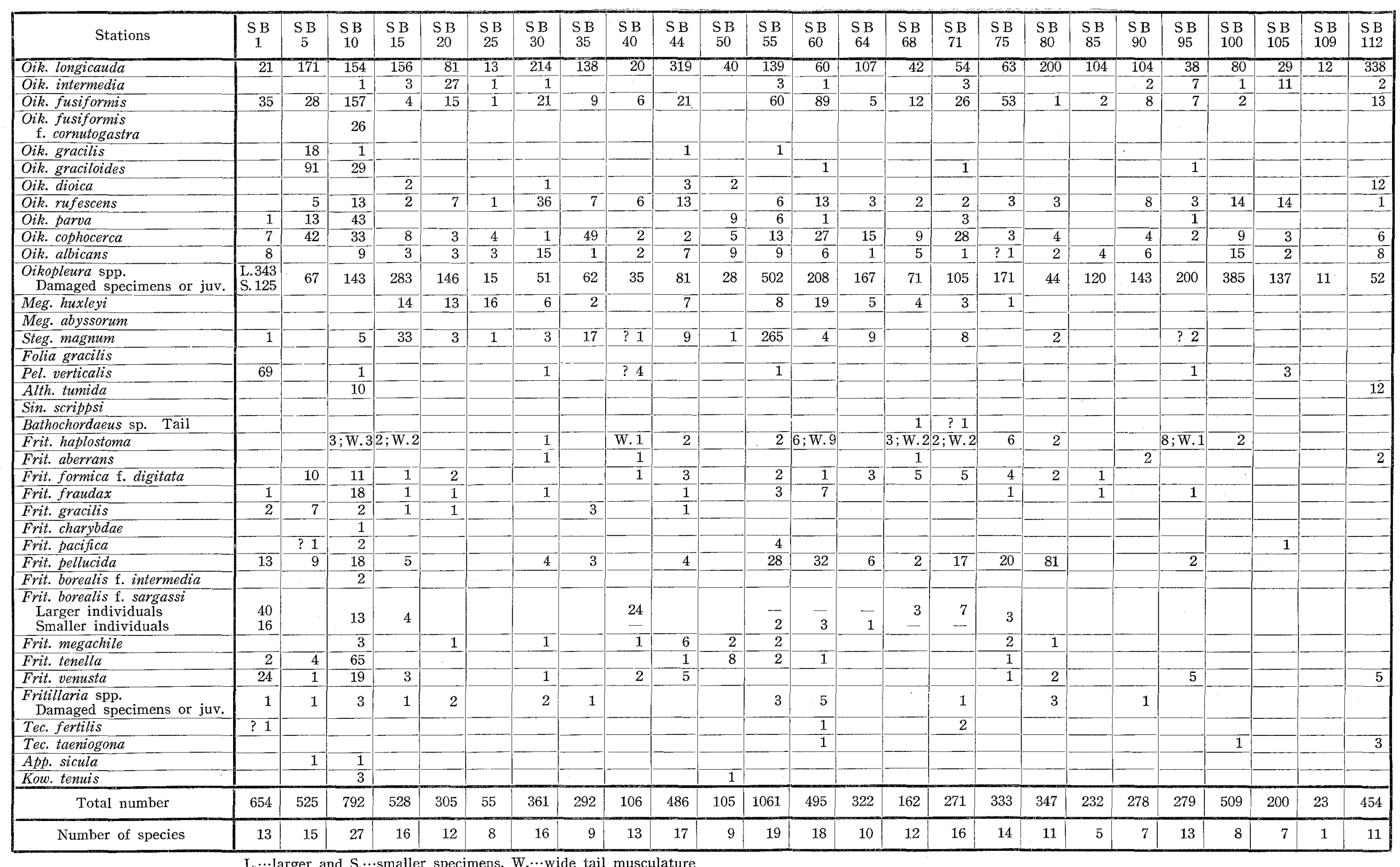

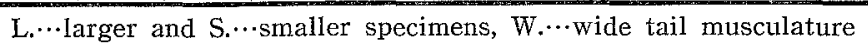

Appendix Table 4-1. Appendicularians of the Shellback Expedition. 
4-2

\begin{tabular}{|c|c|c|c|c|c|c|c|c|c|c|c|c|c|c|c|c|c|c|c|c|c|c|c|c|c|}
\hline Stations & $\begin{array}{l}\text { SB } \\
115\end{array}$ & $\begin{array}{l}\text { SB } \\
118\end{array}$ & $\begin{array}{l}\mathrm{SB} \\
122\end{array}$ & $\begin{array}{l}\mathrm{SB} \\
125\end{array}$ & $\begin{array}{l}\mathrm{SB} \\
130\end{array}$ & $\begin{array}{l}\mathrm{SB} \\
132\end{array}$ & $\begin{array}{l}\text { SB } \\
137\end{array}$ & $\begin{array}{l}\mathrm{SB} \\
142\end{array}$ & $\begin{array}{l}\text { S B } \\
145\end{array}$ & $\begin{array}{l}S B \\
150\end{array}$ & $\begin{array}{l}\mathrm{SB} \\
155\end{array}$ & $\begin{array}{l}\mathrm{SB} \\
160\end{array}$ & $\begin{array}{l}\mathrm{SB} \\
166\end{array}$ & $\begin{array}{l}\mathrm{SB} \\
170\end{array}$ & $\begin{array}{l}\mathrm{SB} \\
175\end{array}$ & $\begin{array}{l}\text { SB } \\
180\end{array}$ & $\begin{array}{l}\mathrm{SB} \\
181\end{array}$ & \begin{tabular}{l|}
$\mathrm{SB}$ \\
187
\end{tabular} & $\begin{array}{l}\mathrm{SB} \\
195\end{array}$ & $\begin{array}{l}\text { SB } \\
200\end{array}$ & $\begin{array}{l}\mathrm{SB} \\
210\end{array}$ & \begin{tabular}{l|} 
S B \\
215
\end{tabular} & $\begin{array}{ll}\text { S B } \\
217\end{array}$ & F.O. & $\begin{array}{c}\text { Mean } \\
\text { percentage }\end{array}$ \\
\hline Oik. longicauda & 379 & 102 & 15 & 16 & 141 & 357 & 48 & 101 & 79 & 44 & 36 & 104 & 60 & 139 & 222 & 72 & 609 & 121 & 16 & 108 & $\overline{119}$ & 377 & 100 & 100 & $\overline{34}$ \\
\hline Oik. intermedia & 11 & 7 & & & & & 8 & 5 & 4 & 1 & 3 & & & & & & 16 & 9 & & & 10 & & & 48 & 2 \\
\hline Oik. fusiformis & 1 & 3 & & 1 & & & 2 & 2 & & & 1 & 7 & & 3 & 16 & & 29 & 15 & 2 & 61 & 34 & 500 & 42 & 79 & 6 \\
\hline $\begin{array}{l}\text { Oik. fusiformis } \\
\text { f. cornutogastra }\end{array}$ & & & & & & & & & & & & 4 & & & & & & & & 1. & 4 & 1 & & 10 & 1 \\
\hline Oik. gracilis & & & & & & & & & & & & & & & & & & & & 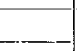 & & & & 8 & 1 \\
\hline Oik. graciloides & & & & & & & & & & & & & & & & & & 1 & & & - & 4 & 4 & 17 & 3 \\
\hline Oik. dioica & - & 2 & & 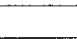 & & & & & & & & 2 & & & & & 2 & & & & & & 7 & 19 & 1 \\
\hline Oik. rufescens & m & & & & & & 56 & 50. & 22 & 41 & & 10 & 21 & 3 & 14 & 1 & & 46 & & 268 & 14 & 17 & 91 & 73 & 7 \\
\hline Oik. parva & 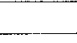 & & & & & & & & & & & & & & & & & $? 3$ & & & ? 1 & & & 21 & 2 \\
\hline Oik cophocerca & & & & & & & 11 & 24 & 65 & 26 & 17 & 15 & 112 & 6 & 38 & 14 & 9 & 72 & & 3 & 44 & 3 & & 79 & 7 \\
\hline Oik. albicans & 15 & 4 & 2 & 2 & & ? 1 & 13 & 4 & 7 & 4 & 18 & 1 & 1 & 13 & 4 & 10 & 36 & 64 & 37 & 2 & 21 & & & 88 & 3 \\
\hline $\begin{array}{l}\text { Oikopleura spp. } \\
\text { Damaged specimens or juv. }\end{array}$ & 229 & 55 & 48 & 57 & 106 & 172 & 123 & 57 & 75 & 43 & 59 & 41 & 14 & 69 & 121 & 133 & 102 & 94 & 113 & 113 & 103 & 348 & 178 & 100 & 37 \\
\hline Meg. huxleyi & & 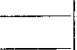 & & & & & & & 1 & & & 1 & & & 3 & 1 & & 4 & 1 & 11 & & & 2 & 42 & 3 \\
\hline Meg. abyssorum & & & & & & & & & 1 & & & & & & & & & & & & & & & 2 & $*$ \\
\hline Steg. magnum & 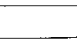 & & & & & & 5 & 4 & 1 & 4 & & & 4 & 1 & 41 & & & 10 & & 8 & 7 & 4 & 13 & 58 & 3 \\
\hline Folia gracilis & & & & & & & & 1 & & & & & & & & & & & & & & & & 2 & $*$ \\
\hline Pel. verticalis & & & & & & & $? 1$ & $? 1$ & & & & & & & & & & 1 & & & & & & 21 & 2 \\
\hline Alth. tumida & 2 & 1 & 3 & 9 & & & & & & & & & & & & & & & & & & & & 13 & 3 \\
\hline Sin. scrippsi & & & & $2_{2}$ & & & & & ? 1 & 1 & & & & & & juv. 3 & & & & & & & & 8 & 1 \\
\hline Bathochordaeus sp. Tail & & 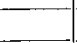 & & & & & & & & & & & & $? 1$ & & & & & & 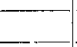 & $? 1$ & & & 8 & s \\
\hline Frit. haplostoma & & & - & - & & & & & & & & & & & & $? 1$ & & & & & & $5 ; \mathrm{W} .2$ & & 31 & 1 \\
\hline Frit. aberrans & 1 & & & & & & 6 & & & & 1 & 2 & & 3 & & 8 & & 2 & & 1 & 14 & & & 29 & 1 \\
\hline Frit. formica f. digitata & & & & & & & 1 & & & & 1 & 1 & 1 & 4 & 5 & 2 & & 3 & & 1 & 5 & 4 & & 52 & 1 \\
\hline Frit. fraudax & & & & & & & & & & & & & & & & & & & & & & 3 & & 25 & * \\
\hline Frit. gracilis & & & & & & & - & & & & & & & 2 & & & & & & & 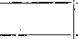 & & & 17 & $*$ \\
\hline Frit. charybdae & & & & & & & & & & & & & & & & & & & & & & 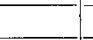 & & 2 & $*$ \\
\hline Frit. pacifica & & & & & & & 3 & & & & 1 & & & & & 3 & & & & & & & & 15 & 1 \\
\hline Frit. pellucide & & & - & & & & & & & 1 & & 4 & & 1 & 12 & 1 & 1 & 11 & & & 18 & 10 & & 50 & 3 \\
\hline Frit. borealis f. intermedia & & & - & & & & & & & & & & & & & -1 & & & & & 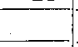 & 17 & & 4 & 1 \\
\hline $\begin{array}{l}\text { Frit. borealis f. sargassi } \\
\text { Larger individuals } \\
\text { Smaller individuals }\end{array}$ & & & & & & & & & & & & & & & & $\overline{1}$ & $\overline{1}$ & $\begin{array}{l}4 \\
1\end{array}$ & & & 7 & $\begin{array}{l}7 \\
1\end{array}$ & $\begin{array}{l}9 \\
1\end{array}$ & 33 & 3 \\
\hline Frit. megachile & & & & & & & 2 & 1 & 1 & & & & & 1 & 1 & & & 1 & & & & & & 31 & * \\
\hline Frit. tenella & & & & & & & & & & 3 & & & & & & 2 & & $\frac{2}{2}$ & & & 3 & 11 & & 27 & 2 \\
\hline Frit, venusta & 4 & & 3 & & & & 11. & E & & 1 & - & & 1 & 2 & & & & 1 & & & 4 & 6 & 1 & 44 & 1 \\
\hline $\begin{array}{l}\text { Fritillaria spp. } \\
\text { Damaged specimens or juv. }\end{array}$ & & & & & 1 & & 3 & 1 & & & 1 & 3 & & & & 7 & & & & & & 16 & & 40 & 1 \\
\hline Tec. fertilis & & & & & & & & & & 2 & & & & & $? 1$ & 19 & & $\overline{1}$ & & & & & & 15 & 1 \\
\hline Tec. taeniogona & 1 & & & 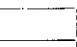 & & 5. & & & & & & & & 1 & & & - & 24 & & & & & & 15 & 1 \\
\hline App. sicula & & & & & & & & & & 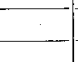 & - & $\ldots$ & 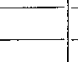 & 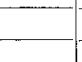 & & - & - & 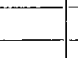 & - & $\ldots$ & 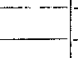 & 2 & 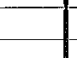 & -4 & $*$ \\
\hline$\frac{\text { Kow. tenuis }}{\text { Total number }}$ & 643 & 174 & 71 & 87 & 248 & 535 & 298 & 251 & 257 & 171 & 138 & 195 & 214 & 276 & 478 & 278 & 805 & 490 & 169 & 577 & 409 & 1338 & 448 & \multirow{2}{*}{\multicolumn{2}{|c|}{$\begin{array}{l}\text { * less than } 0.5 \\
\text { F.O...Frequency } \\
\text { of Occurrence }\end{array}$}} \\
\hline Number of species & 8 & 6 & 4 & 5 & 1 & 3 & 13 & 10 & 10 & 11 & 8 & 11 & 7 & 14 & 11 & 14 & 8 & 20 & 4 & 10 & 16 & 16 & 9 & & \\
\hline
\end{tabular}

Appendix Table 4-2. Appendicularians of the Shellback Expedition. 
$5-1$

\begin{tabular}{|c|c|c|c|c|c|c|c|c|c|c|c|c|c|c|c|c|c|c|c|c|c|c|c|c|c|}
\hline Stations & $\begin{array}{c}\mathrm{SB} \\
1\end{array}$ & $\begin{array}{c}\text { SB } \\
5\end{array}$ & $\begin{array}{l}\mathrm{SB} \\
10\end{array}$ & $\begin{array}{l}\mathrm{SB} \\
15\end{array}$ & $\begin{array}{l}\mathrm{SB} \\
20\end{array}$ & $\begin{array}{l}\mathrm{SB} \\
25\end{array}$ & $\begin{array}{l}\mathrm{SB} \\
30\end{array}$ & $\begin{array}{l}\text { S B } \\
35\end{array}$ & $\begin{array}{l}\mathrm{SB} \\
40\end{array}$ & $\begin{array}{l}\text { S B } \\
44\end{array}$ & $\begin{array}{l}\mathrm{SB} \\
50\end{array}$ & $\begin{array}{l}\text { SB } \\
55\end{array}$ & $\begin{array}{l}\text { S B } \\
60\end{array}$ & $\begin{array}{l}\mathrm{SB} \\
64\end{array}$ & $\begin{array}{l}\mathrm{SB} \\
68\end{array}$ & $\begin{array}{c}\mathrm{SB} \\
71\end{array}$ & $\begin{array}{l}\mathrm{SB} \\
75\end{array}$ & $\begin{array}{l}\mathrm{SB} \\
80\end{array}$ & $\begin{array}{l}\mathrm{SB} \\
85\end{array}$ & $\begin{array}{l}\mathrm{SB} \\
90\end{array}$ & $\begin{array}{l}\mathrm{SB} \\
95\end{array}$ & \begin{tabular}{|l|} 
SB \\
100
\end{tabular} & $\begin{array}{l}\mathrm{SB} \\
105\end{array}$ & $\begin{array}{l}\text { S B } \\
109\end{array}$ & $\begin{array}{l}\text { S B } \\
112\end{array}$ \\
\hline $\begin{array}{l}\text { Pyrosoma atlanticum atlanticum } \\
\text { small colonies }\end{array}$ & 1 & & & & 1 & 3 & 4 & 1 & & 5 & 3 & 4 & 6 & & 2 & & 1 & & & 3 & & 6 & 4 & & \\
\hline Cyclosalpa pinnata & & & & $\begin{array}{l}\text { s. } 1 \\
\text { g. } 5 \\
\end{array}$ & g. 5 & & & & & & & g. 1 & & & & & & $\begin{array}{l}\text { s. } 2 \\
\text { g. } 11\end{array}$ & & & & & & & \\
\hline Cyclosalpa floridana & & & & & & & & & & & & & s. 1 & & & s. 1 & & & & & & & & & \\
\hline \multicolumn{26}{|l|}{ Cyclosalpa bakeri } \\
\hline Cyclosalpa strongyrenteron & & & & & & g. 27 & & & & & g. 26 & & & & & & & & & & & & g. 1 & g. 1 & g. 4 \\
\hline Brooksia rostrata & & & & & \begin{tabular}{l|} 
s. 22 \\
g. 2
\end{tabular} & & & s. 1 & & & & s. 2 & & & & & & & & & & & & & \\
\hline Ritteriella amboinensis & & & & & & & $\begin{array}{l}\text { s. } 3 \\
\text { g. } 2\end{array}$ & & & & & & & & & s. 1 & $\begin{array}{l}\text { s. } 2 \\
\text { g. } 2 \\
\end{array}$ & & & & & & & & \\
\hline Metcalfina hexagona & & & & & $\begin{array}{l}\text { s. } 2 \\
\text { g. } 56\end{array}$ & & & & & & & & & $\overline{\text { s. } 3}$ & & s. 1 & & & & & & & & & \\
\hline Salpa fusiformia & & & $\begin{array}{l}\text { s. } 1 \\
\text { g. } 1\end{array}$ & g. 3 & & & g. 9 & g. 1 & & & $\begin{array}{l}\text { s. } 1 \\
\text { g. } 6\end{array}$ & g. 1 & & & & & & & g. 7 & g. 3 & & g. 5 & & & \\
\hline Salpa cylindrica & & s. 1 & s. 1 & & \begin{tabular}{l|l} 
s. 1 \\
g. 3
\end{tabular} & & s. 1 & $\begin{array}{l}\text { s. } 9 \\
\text { g. } 17\end{array}$ & & $\begin{array}{l}\text { s. } 1 \\
\text { g. } 49 \\
\end{array}$ & $\begin{array}{l}\text { s. } 1 \\
\text { g. } 22 \\
\end{array}$ & & s. 1 & & & & & & & g. 4 & \begin{tabular}{|l|} 
s. 1 \\
g. 3 \\
\end{tabular} & & & & \\
\hline Iasis zonaria & & & & & & & & & g. 1 & & & & & g. 1 & & & & g. 7 & g. 3 & g. 1 & $\begin{array}{ll}\text { s. } 1 \\
\text { g. } 1\end{array}$ & & $\mathrm{~g} .1$ & & g. 1 \\
\hline $\begin{array}{l}\text { Thalia democratica sol. } \\
\text { sol. var. orientalis }\end{array}$ & & & $\begin{array}{c}\overline{12} \\
\text { g. } 19 \\
\end{array}$ & $\begin{array}{r}74 \\
10 \\
\text {. } 240 \\
\end{array}$ & & $\begin{array}{r}\overline{5} \\
\text { g. } 11 \\
\end{array}$ & $\underline{1}$ & $\begin{array}{c}1 \\
2 \\
\text { g. } 11 \\
\end{array}$ & & $\begin{array}{r}6 \\
3 \\
\text { g. } 31 \\
\end{array}$ & $\begin{array}{r}\overline{1} \\
\mathrm{~g} .2 \\
\end{array}$ & $\begin{array}{r}7 \\
10 \\
\text { g. } 93 \\
\end{array}$ & $\begin{array}{r}12 \\
3 \\
\text { g. } 29 \\
\end{array}$ & $\begin{array}{c}-26 \\
12 \\
\text { g. } 42 \\
\end{array}$ & $\frac{2}{\text { g. } 1}$ & $\begin{array}{c}\overline{9} \\
\text { g. } 66 \\
\end{array}$ & $\begin{array}{c}18 \\
5 \\
\text { g. } 64 \\
\end{array}$ & $\begin{array}{r}\overline{1} \\
\text { g. } 3 \\
\end{array}$ & $\begin{array}{c}\overline{-} \\
\overline{\text { g. }} \\
\end{array}$ & & $\begin{array}{r}-\overline{4} .1 \\
4 \\
\text { g. }\end{array}$ & $\begin{array}{c}\overline{2} \\
\text { g. } 15 \\
\end{array}$ & $\overline{\overline{-}}$ & & \\
\hline Pegea confoederata & & & g. 14 & & & & & 1 & & & $\begin{array}{l}\text { s. } 1 \\
\text { g. } 1\end{array}$ & & & & & & & & & & & & & & \\
\hline \multicolumn{26}{|l|}{ Traustedtia multitentaculata } \\
\hline Doliolum denticulatum & & & 3 & 1 & 7 & 1 & 2 & 9 & & 10 & & 20 & 7 & & 9 & 9 & 17 & 11 & 33 & 2 & 2 & 17 & 12 & 3 & 15 \\
\hline Doliolum nationalis & 1 & & & & & & & & & & 4 & & & & & & & & & & & & & & 10 \\
\hline $\begin{array}{c}\text { Dolioletta gegenbauri var. } \\
\text { tritonis }\end{array}$ & 1 & & & & & & & & & & 4 & & & & & & & & & & & & 11 & & 102 \\
\hline Doliolina intermedia & & & & & 15 & 3 & & & 70 & & & & & & & & & & 1 & & 26 & 63 & & 5 & 1 \\
\hline \multicolumn{26}{|l|}{ Doliolina undulata } \\
\hline Doliolina obscura & & & & & & & & & & & & & & $? 1$ & & & & & & & & & & & \\
\hline \multicolumn{26}{|l|}{ Doliolina separata } \\
\hline Doliolina spp.* & & & $? 1$ & & & & 1 & & & & & & & & & & & & & & & 1 & & $? 1$ & 1 \\
\hline Doliolid Amme & 50 & 1 & 38 & 142 & 100 & 42 & 24 & 6 & 14 & 37 & 114 & 92 & 112 & 31 & 23 & 29 & 9 & 94 & 17 & 47 & 33 & 183 & 105 & 10 & 130 \\
\hline Doliolid trophozooid & & & 1 & & & & 3 & & & 1 & 17 & & & & & 2 & & & $\overline{1}$ & & 1 & 6 & & & \\
\hline $\begin{array}{l}\text { Doliolids, damaged individuals } \\
\text { or juv. }\end{array}$ & & & & & & & & & & & & 1 & 2 & & & & 1 & & & & & & & & 1 \\
\hline \multicolumn{26}{|l|}{ Doliopsoides horizoni } \\
\hline Doliopsis rubescens & & & & & & & & & 1 & & & & & & & & & & & & 1 & & & & \\
\hline
\end{tabular}

* Unidentified phorozooid, juv. or damaged individuals; $s \cdots$ solitary form, g* aggregated form

Appendix Table 5-1. Thaliaceans of the Shellback Expedition. 
5-2

\begin{tabular}{|c|c|c|c|c|c|c|c|c|c|c|c|c|c|c|c|c|c|c|c|c|c|c|c|c|}
\hline Stations & $\begin{array}{l}\text { SB } \\
115\end{array}$ & $\begin{array}{l}S B \\
118\end{array}$ & $\begin{array}{l}\mathrm{SB} \\
122\end{array}$ & $\begin{array}{l}\text { S B } \\
125\end{array}$ & $\begin{array}{l}\mathrm{SB} \\
130\end{array}$ & $\begin{array}{l}\text { SB } \\
132\end{array}$ & $\begin{array}{l}\text { SB } \\
137\end{array}$ & $\begin{array}{l}\text { S B } \\
142\end{array}$ & $\begin{array}{l}\text { S B } \\
1.45\end{array}$ & $\begin{array}{l}\text { SB } \\
150\end{array}$ & $\begin{array}{l}\text { S B } \\
155\end{array}$ & $\begin{array}{l}\mathrm{SB} \\
160\end{array}$ & $\begin{array}{l}\mathrm{SB} \\
166\end{array}$ & $\begin{array}{l}\text { S B } \\
170\end{array}$ & $\begin{array}{l}\text { S B } \\
1.75\end{array}$ & $\begin{array}{l}\mathrm{SB} \\
180\end{array}$ & $\begin{array}{l}\text { SB } \\
181\end{array}$ & $\begin{array}{l}\mathrm{SB} \\
187\end{array}$ & $\begin{array}{l}\mathrm{SB} \\
195\end{array}$ & $\begin{array}{l}\text { S B } \\
200\end{array}$ & $\begin{array}{l}\text { SB } \\
210\end{array}$ & $\begin{array}{l}\text { SB } \\
215\end{array}$ & $\begin{array}{l}\text { SB } \\
217\end{array}$ & F.O. \\
\hline $\begin{array}{l}\text { Pyrosoma atlanticum atlanticum } \\
\text { small colonies }\end{array}$ & 13 & 2 & & & & & & & 2 & 6 & & & & & & & & & & 1 & & & & 40 \\
\hline Cyclosalpa pinnata & & & & & & & & & & & & & & & & & & & & & & & & 8 \\
\hline Cyclosalpa floridana & & & & & & & & & & & & & & & & & & & & & & & & 4 \\
\hline Cyclosalpa bakeri & g. 2 & & & & & & & s. 2 & & g. 1 & & & & & & & & & & & & & & 6 \\
\hline Cyclosalpa strongyrenteron & & & & & & & & & & g. 2 & & & & & & & & & & & & & & 13 \\
\hline Brooksia rostrata & & & & & & & & & & & & & & & & & & & & & & & & 6 \\
\hline Ritteriella amboinensis & & & & & & & & & & & & $\begin{array}{l}\text { s. } 7 \\
\text { g. } 14 \\
\end{array}$ & & & $\begin{array}{l}\text { s. } 1 \\
\text { g. } 1 \\
\end{array}$ & & & $\begin{array}{l}\text { s. } 10 \\
\text { g. } 2 \\
\end{array}$ & & $\begin{array}{l}\text { S. } 1 \\
\text { g. } 6 \\
\end{array}$ & & & & 15 \\
\hline Metcalfina hexagona & & & & & & & & & & & & & & & & & & & & & s. 2 & & & 8 \\
\hline Salpa fusiformis & & & & & & & & & & & & & & & & & & & s. 1 & & & & & 21 \\
\hline Salpa cylindrica & g. 2 & & & & s. 3 & & $\begin{array}{l}\text { s. } 7 \\
\text { g. } 5\end{array}$ & & $\begin{array}{ll}\text { s. } 6 \\
\text { g. } 21 \\
\end{array}$ & & & s. 3 & g. 3 & & & & & s. 1 & s. 1 & s. 6 & & s. 1 & s. 5 & 44 \\
\hline Iasis zonaria & g. 2 & s. 1 & & & & & & & g. 6 & g. 1 & & g. 3 & s. 1 & & g. 1 & & g. 1 & & & g. 4 & g. 2 & & & 38 \\
\hline $\begin{array}{l}\text { Thalia democratica sol. } \\
\text { sol. var. orientalis }\end{array}$ & & & & & \begin{tabular}{c|}
$\frac{6}{2}$ \\
g.
\end{tabular} & & $\begin{array}{c}438 \\
167 \\
\text { g. } 4088\end{array}$ & \begin{tabular}{|c|}
$\overline{16}$ \\
g. 41 \\
\end{tabular} & $\begin{array}{c}4 \\
17 \\
\text { g. } 94\end{array}$ & 1 & & $\begin{array}{c}2 \\
4 \\
\text { g. } 19 \\
\end{array}$ & $\begin{array}{r}2 \\
6 \\
- \\
\end{array}$ & $\overline{1}$ & $\begin{array}{r}10 \\
7 \\
\text { g. } 25 \\
\end{array}$ & & $\begin{array}{l}- \\
\overline{\text { g. } 2}\end{array}$ & $\begin{array}{c}3 \\
3 \\
\text { g. } 39 \\
\end{array}$ & & $\begin{array}{c}\overline{-} \\
\text { g. } 25 \\
\end{array}$ & $\begin{array}{c}1 \overline{6} \\
\text { g. } 33 \\
\end{array}$ & & $\begin{array}{c}\frac{1}{\text { g. } 5} \\
\end{array}$ & $\left.\begin{array}{l}35 \\
50 \\
58\end{array}\right\} 67$ \\
\hline Pegea confoederata & & & & & & & & & & & & & & & & & & & & & & & & 6 \\
\hline Traustedtia multitentaculata & & & & & & & & s. 2 & & & & & & & & & & & & & & & & 2 \\
\hline Doliolum denticulatum & 127 & 2 & & 3 & & & 33 & 41 & 34 & 81 & 103 & 35 & 4 & 24 & 32 & 32 & 229 & 40 & 11 & 138 & 19 & & 1 & 81 \\
\hline Doliolum nationalis & 133 & 2 & 1 & 5 & 3 & & 598 & 24 & 2 & 11 & 13 & 1 & & & 1 & 1 & & & 2 & 2 & & 14 & 9 & 42 \\
\hline $\begin{array}{l}\text { Dolioletta gegenbauri var. } \\
\text { tritonis }\end{array}$ & 6 & 380 & 150 & 19 & & 3 & 99 & & & $\overline{1}$ & & & & & & & 1 & $\sqrt{4}$ & & & & & & 27 \\
\hline Doliolina intermedia & 23 & 15 & 79 & 74 & 19 & 5 & & & 9 & 10 & 1 & & & 1 & & & & & & 10 & & 1 & & 42 \\
\hline Doliolina undulata & 5 & & & & & 2 & 35 & 3 & & 1 & & & & & & & 1 & $? 1$ & & & $? 1$ & 2 & & 19 \\
\hline Doliolina obscura & & & & & & & 50 & 2 & 1 & & 16 & $? 1$ & & & & 3 & & 6 & & & & & & 17 \\
\hline Dotiolina separata & & & & & & & + & & + & & & & & & & + & & & & & & & & 6 \\
\hline Doliolina spp. * & & & & & & & 14 & & 1 & & & & & & & $? 1$ & & & & & & & & 17 \\
\hline Doliolid Amme & 48 & 34 & 65 & 20 & 5 & 1 & 86 & 110 & 172 & 110 & 252 & 101 & 24 & 65 & 105 & 284 & 171 & 187 & 156 & 279 & 20 & 14 & 43 & 100 \\
\hline Doliolid trophozooid & & & & & 1 & & & & 1 & & & 2 & & & & 1 & & 2 & & 1 & & & & 29 \\
\hline $\begin{array}{l}\text { Doliolids, damaged individuals } \\
\text { or juv. }\end{array}$ & 7 & 1 & & 4 & 1 & 4 & 19 & 1 & 4 & 3 & & & & & & 1 & 1 & 3 & & & & & & 33 \\
\hline Doliopsoides horizoni & 3 & 1 & 4 & 12 & & & 13 & 51 & 2 & 1 & 1 & & & & & & & & & & & & & 19 \\
\hline Doliopsis rubescens & & & & & & & & & & & & & & & & & & & & & & & & 4 \\
\hline
\end{tabular}

Appendix Table 5-2. Thaliaceans of the Shellback Expedition.

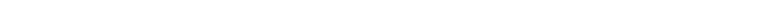


$6-1$

\begin{tabular}{|c|c|c|c|c|c|c|c|c|c|c|c|c|c|c|c|c|c|c|c|c|c|c|c|c|c|}
\hline Stations & TP1 & TP3 & TP4 & TP6 & $\mathrm{TP} 7$ & TP 8 & TP 9 & TP 10 & TP11 & TP12 & TP 13 & TP14 & TP 15 & $|\mathrm{TP} 16|$ & TP17 & TP18 & TP 26 & TP 33 & TP 51 & TP 52 & TP 53 & TP55B & TP 56 & TP57A & TP58A \\
\hline Oik. Longicauda & 491 & 33 & & 1 & 1 & 11 & 49 & & & & 51 & 110 & 273 & 209 & 246 & & 1 & 1 & 12 & 11 & 4 & & 6 & 21 & 4 \\
\hline \multicolumn{26}{|l|}{ Oik. intermedia } \\
\hline Oik. fusiformis & 25 & 43 & 7 & 14 & 3 & 2 & 203 & 31 & 87 & 61 & & 2 & & & & & & & & 10 & 15 & & & & 10 \\
\hline \multicolumn{26}{|l|}{$\begin{array}{l}\text { Oik. fusiformis } \\
\text { f. cornutogastra }\end{array}$} \\
\hline \multicolumn{26}{|l|}{ Oik. gracilis } \\
\hline \multicolumn{26}{|l|}{ Oik. graciloides } \\
\hline Oik. dioica & 1 & 155 & & & & & & & & & & & & & & & & & & & 4 & 2 & & & \\
\hline \multicolumn{26}{|l|}{ Oik. rufescens } \\
\hline \multicolumn{26}{|l|}{ Oik. parva } \\
\hline Oik. cophocerca & 2 & 4 & & & & & & & & & & & & & & & & & & & & & & & \\
\hline Oik. albicans & & & & & & 1 & & & & & & & & & & & & & & & & & & & \\
\hline Oik. labradoriensis & & & & & & & & & & & & & & & . & 4 & 2 & 5 & 25 & 14 & . & & & 13 & 5 \\
\hline $\begin{array}{l}\text { Oikopleura spp. } \\
\text { Damaged specimens or juv. }\end{array}$ & 8 & 73 & 3 & 2 & & 3 & 43 & 6 & 1 & 1 & & 4 & & 2 & 5 & & & & 2 & 2 & 1 & 1 & & 1 & 1 \\
\hline \multicolumn{26}{|l|}{ Meg. huxleyi } \\
\hline \multicolumn{26}{|l|}{ Steg. magnum } \\
\hline \multicolumn{26}{|l|}{ Alth. tumida } \\
\hline \multicolumn{26}{|l|}{ Frit. haplostoma } \\
\hline \multicolumn{26}{|l|}{ Frit. abjornseni } \\
\hline \multicolumn{26}{|l|}{ Frit. aberrans } \\
\hline \multicolumn{26}{|l|}{ Frit. formica f. digitata } \\
\hline \multicolumn{26}{|l|}{ Frit. pacifica } \\
\hline Frit. pellucida & & & & & & & & & & & & & & 1 & 3 & 18 & & & & 1 & & & & & \\
\hline Frit. borealis f. typica & 2 & 3 & & & & & & & & 1 & & & & 1 & & & & & 14 & 3 & & & 1 & 2 & 576 \\
\hline $\begin{array}{l}\text { Frit. borealis f. sargassi } \\
\text { Larger individuals } \\
\text { Smaller individuals }\end{array}$ & $\overline{12}$ & $\overline{16}$ & 7 & $\overline{31}$ & 3 & & 9 & $\overline{7}$ & $\overline{3}$ & $\overline{13}$ & & & & & & & & & & & & & & & \\
\hline Frit. megachile & & & & & & & & & & 1 & & & & & & & & & & & & & & & \\
\hline $\begin{array}{l}\text { Fritillaria spp. } \\
\text { Damaged specimens or juv. }\end{array}$ & 1. & & & & & & & & & & & & & & & & & & & & & & & & \\
\hline \multicolumn{26}{|l|}{ Tect. fertilis } \\
\hline App. sicula & & & & & & 1 & & 1 & & & & & & & & & & & & & & & & & \\
\hline \multicolumn{26}{|l|}{ Kow. tenuis } \\
\hline Total number & 542 & 327 & 17 & 48 & 7 & 18 & 295 & 45 & 91 & 77 & 51 & 116 & 273 & 213 & 254 & 22 & 3 & 6 & 53 & 41 & 24 & 3 & 7 & 37 & 596 \\
\hline Number of species & 6 & 6 & 2 & 3 & 3 & 4 & 3 & 3 & 2 & 4 & 1 & 2 & 1 & 3 & 2 & 2 & 2 & 2 & 3 & 5 & 3 & 1 & 2 & 3 & 4 \\
\hline
\end{tabular}

Appendix Table 6-1. Appendicularians of the Transpac Expedition. 
$6-2$

\begin{tabular}{|c|c|c|c|c|c|c|c|c|c|c|c|c|c|c|c|c|c|c|c|c|c|c|c|c|c|}
\hline Stations & TP $59 \mathrm{~A}$ & TP 61 & TP 67 & TP 68 & TP 69 & TP 70 & TP71 & TP 72 & TP73 & TP 74 & TP76 & TP 78 & TP 79 & TP 80 & $\mathrm{TP} 80^{\prime}$ & TP 81 & TP 82 & TP 83 & TP 84 & TP 85 & TP 89 & TP 92A & TP93 & TP 94 & TP 95 \\
\hline Oik. longicauda & 9 & 10 & 38 & 28 & 266 & 58 & 71 & 24 & 36 & 132 & 307 & 942 & 198 & 23 & 6 & 38 & 52 & 31 & 6 & 47 & 44 & 98 & 139 & 51 & 197 \\
\hline Oik. intermedia & & & & & & & & & & & 1. & & & & & & & & & & & & & & \\
\hline Oik. fusiformis & 10 & & & & 311 & 18 & 36 & & & 6 & 75 & 146 & 163 & 8 & 1 & 29 & 80 & 37 & 10 & 29 & 23 & 38 & 44 & 44 & 40 \\
\hline $\begin{array}{l}\text { Oik fusiformis } \\
\text { f. cormutogastra }\end{array}$ & & & & & & & & & & & & & 2 & & & & & & & 4 & & & 1 & & 8 \\
\hline Oik. gracilis & & & & & & & & & & & & & & & & & & & & & & & & & 2 \\
\hline Oik. graciloides & & & & & & & & & & & & & 2 & & & 1 & & & 2 & 1 & & & 3 & & \\
\hline Oik. dioica & & & & & & 2 & 2 & & 21 & & & 3 & 9 & & & & 4 & & & . & & & 7 & 20 & \\
\hline Oik. rufescens & & & & & & 7 & & & & & 15 & 16 & 17 & 10 & & 3 & 8 & 5 & & 6 & 9 & 11 & 22 & & 50 \\
\hline Oik. parva & & & & & & & & & & & & & & & & & & & & & & & & & \\
\hline Oik. cophocerca & & & & . & & 1 & & & & & 1 & & & & & & & 1 & & & 1 & & 3 & & 14 \\
\hline Oik. albicans & & & & & & & & & & & & & & & & & & & & & & & & & \\
\hline Oik. labradoriensis & & 5 & 5 & 1 & & & & & 2 & & & & & & & & & . & & & & & & & \\
\hline $\begin{array}{l}\text { Oikopleura spp. } \\
\text { Damaged specimens or juv. }\end{array}$ & 3 & & & & 9 & 1 & 5 & 8 & 3 & 1 & 8 & 31 & 10 & 8 & 19 & 19 & 14 & 31 & 8 & $\overline{10}$ & 9 & 12 & 7 & 7 & 69 \\
\hline Meg. huxleyi & & & & & & 1 & & & & & & & & & & & 2 & 3 & & 1 & 1 & 3 & 2 & & 5 \\
\hline Steg. magnum & & & & & & & & & & & & & 5 & & 1 & 1 & 9 & 3 & & 9 & 2 & & & 1 & 4 \\
\hline Alth. tumida & & & & & & & & & & & & & & & & & & & & & & & & & \\
\hline Frit. haplostoma & & & & & & 3 & & & & & & & 3 & & & 1 & 6 & 1 & & 1 & & & & 1 & \\
\hline Frit. abjornseni & & & & & & & & & & & & & 1 & & & & & & & 1 & & & & & \\
\hline Frit. aberrans & & & & & & & & & & & & & & & & & & & & & & & & & \\
\hline Frit. formica f. digitata & & & & & & 5 & & & & 2 & & 6 & 1 & & & 2 & & 1 & & 1 & 3 & 2 & 4 & 2 & 13 \\
\hline Frit. pacifica & & & & & & & & & & & & & & & & & & & & & & & & & \\
\hline Frit. pellucida & & & & & & 1. & & & & 9 & 3 & & 5 & & & & & & 2 & 3 & & & 1 & & 1 \\
\hline Frit. borealis f. typica & 52 & & & & & & & & & & 1 & 1 & 1 & 2 & & & & & & & & & & & \\
\hline $\begin{array}{l}\text { Frit. borealis f. sargassi } \\
\text { Larger individuals } \\
\text { Smaller individuals } \\
\end{array}$ & & & & & 2 & $\overline{3}$ & & & & $\overline{1}$ & $\overline{14}$ & $\stackrel{2}{-}$ & $\begin{array}{r}3 \\
32 \\
\end{array}$ & $\overline{3}$ & & $\begin{array}{l}3 \\
6 \\
\end{array}$ & $\begin{array}{l}1 \\
4 \\
\end{array}$ & $\begin{array}{r}1 \\
11 \\
\end{array}$ & $\begin{array}{r}3 \\
29 \\
\end{array}$ & $\overline{9}$ & $\begin{array}{l}1 \\
8 \\
\end{array}$ & & $\overline{14}$ & $\overline{9}$ & 7 \\
\hline Frit. megachile & & & & & & & & & & & & & & & & & & & & & & & & & \\
\hline $\begin{array}{l}\text { Fritillaria spp. } \\
\text { Damaged specimens or juv. }\end{array}$ & & & & & & & & & & & & & 2 & 1 & & & & 1 & & & & & & & 2 \\
\hline Tect. fertilis & & & & & & 11 & & & & & 5 & & & & & & 1 & & & & & & & 1 & 3 \\
\hline App. sicula & & & & & & & & & & 1 & 1 & & 3 & & & & & 1 & & & & 13 & 1 & 1 & \\
\hline Kow. tenuis & & & & & & & & & & & 2 & . & & & & & & & & & & & & & \\
\hline Total number & 74 & 15 & 43 & 29 & 588 & 111 & 114 & 32 & 62 & 152 & 433 & 1147 & 457 & 55 & 27 & 103 & 181 & 127 & 60 & 122 & 101 & 177 & 248 & 137 & 415 \\
\hline Number of species & 3 & 2 & 2 & 2 & 3 & 11 & 3 & 1 & 3 & 6 & 11 & 7 & 14 & 5 & 3 & 8 & 9 & 11 & 5 & 12 & 8 & 6 & 12 & 9 & 12 \\
\hline
\end{tabular}

Appendix Table 6-2. Appendicularians of the Transpac Expedition. 
$6-3$

\begin{tabular}{|c|c|c|c|c|c|c|c|c|c|c|c|c|c|c|c|c|c|c|c|c|c|c|c|c|c|}
\hline Stations & ТР 96 & TP 97 & ТР 98 & TP 99 & TP 99' & $\begin{array}{l}\text { Entrance } \\
\text { to } \\
\text { Yookosuka }\end{array}$ & TP100 & TP 101 & TP 102 & $2 \operatorname{TP} 103$ & 3TP 104 & TP 105 & $5 \mid \mathrm{TP} 106$ & SP.107] & TP 108 & $8 \mathrm{TP} 109$ & 9 TP111 & $\mathrm{TP} 112$ & $2 \mathrm{TP} 113$ & 13 TP 114 & TP $114^{\prime}$ & $\operatorname{TP} 115$ & 5 TP 116 & 6 TP117 & $7 \mathrm{TP} 118$ \\
\hline Oik. longicauda & 30 & 75 & 13 & 123 & 141 & . & 57 & 31 & 179 & 7 & 32 & 42 & 68 & 3 & 48 & 92 & 21 & & 9 & 2 & 7 & 10 & 15 & 1 & 53 \\
\hline Oik. intermedia & & & & & & & & & & & & & & & & & & & 4 & & & & & & \\
\hline Oik. fusiformis & 8 & 19 & 20 & 44 & 31 & & 13 & 9 & 69 & 7 & 9 & 12 & 3 & & 1 & 11 & 10 & 24 & 39 & 3 & 1 & 10 & 2 & 18 & 7 \\
\hline $\begin{array}{l}\text { Oik. fusiformis } \\
\text { f. cornutogastra }\end{array}$ & & & & 1 & 1 & & & & & & & & & & & & & & & & & & & & \\
\hline \multicolumn{26}{|l|}{ Oik. gracilis } \\
\hline Oik. graciloides & & & 4 & & & & & 2 & 6 & 1 & 2 & 2 & & & & & 1 & & & & & & & & \\
\hline Oik. dioica & 3 & 2 & & & & 8 & & & 1 & & & & 2 & & 4 & 2 & & & 1 & & & 1 & & 3 & 7 \\
\hline Oik. rufescens & & 7 & 2 & 31 & 10 & & 10 & 5 & 30 & 2 & 5 & & 3 & & 16 & 30 & 2 & & 6 & 2 & 3 & 3 & & & 7 \\
\hline Oik. parva & & & & & & & & & & & & & & & & & & & . & & & & . & & 1 \\
\hline Oik. cophocerca & & & & 4 & & & 3 & & & & & & & & & & 1 & & 1 & & & & 2 & & \\
\hline Oik. albicans & & & & & & & & & 1 & & 1 & & & & & & & & & & & & & & \\
\hline \multicolumn{26}{|l|}{ Oik. labradoriensis } \\
\hline $\begin{array}{l}\text { Oikopleura spp. } \\
\text { Damaged specimens or juv. }\end{array}$ & 5 & 7 & 2 & 11 & 139 & & 18 & 8 & 23 & 8 & 30 & 2 & 17 & & 3 & 4 & 5 & 2 & & 1 & 2 & 8 & & 6 & 7 \\
\hline Meg. huxleyi & & 3 & & & 2 & & & & 2 & & 1 & & & & & & & & & & & & & & \\
\hline Steg. magnum & & 2 & & 5 & & & 2 & 2 & 7 & & & & & & 1 & 1 & & & & & & & & & 2 \\
\hline Alth. tumida & & & & & & & 1 & & & & & & & & & & & & & & & & & & \\
\hline Frit. haplostoma & & & & 2 & 1 & & 1 & & & & & & & & & & & & & & & & & & \\
\hline \multicolumn{26}{|l|}{ Frit. abjornseni } \\
\hline \multicolumn{26}{|l|}{ Frit. aberrans } \\
\hline Frit. formica f. digitata & 3 & & & 4 & 1 & & 1 & & & & & & 2 & & & & & & & & & & & 1 & \\
\hline \multicolumn{26}{|l|}{ Frit. pacifica } \\
\hline Frit. pellucida & & & & 1 & 1 & & & & 2 & & 2 & & & & & & & & & & & & & & \\
\hline Frit. borealis f. typica & & & & 2 & & & & & & & & & & & & & & & & & & & & & \\
\hline $\begin{array}{l}\text { Frit. borealis f. sargassi } \\
\text { Larger individuals } \\
\text { Smaller individuals }\end{array}$ & $\overline{9}$ & $\stackrel{1}{-}$ & $\overline{1}$ & $\overline{12}$ & 4 & & $\begin{array}{r}1 \\
12 \\
\end{array}$ & $-\overline{4}$ & $\overrightarrow{22}$ & & $\overline{4}$ & & $\overline{3}$ & & $\overline{4}$ & $\overline{8}$ & $\overline{1}$ & $\overline{1}$ & $\overline{3}$ & $\overline{1}$ & & & $\overline{1}$ & & $\overline{2}$ \\
\hline \multicolumn{26}{|l|}{ Frit. megachile } \\
\hline $\begin{array}{l}\text { Fritillaria spp. } \\
\text { Damaged specimens or juv. }\end{array}$ & & & & 1 & 1 & & & & & & & & & & & 1 & & & & & & & & 1 & \\
\hline Tect. fertilis & & & & 2 & & & 1 & & 2 & & & 1 & 3 & & 1 & 4 & & & & & & & & 2 & 2 \\
\hline App. sicula & & 1 & & 2 & & & 1 & & & & & & 3 & & 1 & 4 & 1 & & & & & & & & 2 \\
\hline \multicolumn{26}{|l|}{ Kow. tenuis } \\
\hline Total number & 58 & 117 & 42 & 245 & 332 & 8 & 121 & 61 & 344 & 25 & 86 & 59 & 104 & 3 & 79 & 157 & 42 & 27 & 63 & 9 & 13 & 32 & 20 & 32 & 90 \\
\hline Number of species & 5 & 8 & 5 & 13 & 9 & 1 & 11 & 6 & 11 & 4 & 8 & 4 & 8 & 1 & 8 & 8 & 7 & 2 & 7 & 4 & 3 & 4 & 4 & 5 & 9 \\
\hline
\end{tabular}

Appendix Table 6-3. Appendicularians of the Transpac Expedition. 


\begin{tabular}{|c|c|c|c|c|c|c|c|c|c|c|c|c|c|c|c|c|c|c|c|c|c|c|c|c|}
\hline Stations & TP 119 & $\mathrm{PP} 120$ & TP 121 & TP 122 & $\operatorname{TP} 123$ & BTP 124 & $\mathrm{TP} 125$ & $25 \mid \begin{array}{c}\text { near } \\
\text { Midway }\end{array}$ & TP 126 & $6 \mathrm{TP} 127$ & $7 \mathrm{TP} 128$ & $8 \mathrm{TP} 129$ & $9 \mathrm{TP} 130$ & 0 & $1 * \mathrm{TP} 131 \mathrm{~B}$ & BTP 132 & TP 133 & TP 134 & $4 \mathrm{TP} 135$ & 5 TP 137 & $7 \mathrm{TP} 141$ & *ST 89 & F.o. & $\mid \begin{array}{c}\text { Mean } \\
\text { percentage }\end{array}$ \\
\hline Oik. longicauda & 13 & & 3 & 1 & & & & & 1 & 1 & 2 & & 1 & 1 & 20 & 6 & 1 & 1 & 13 & 6 & 3 & 2 & 87 & 44 \\
\hline Oik. intermedia & & & & & & & & & & & & & & & & & & & & & & & 2 & 3 \\
\hline Oik. fusiformis & 4 & 1 & 1 & 1 & 1 & 7 & 9 & & 4 & 2 & 8 & 7 & 1 & 2 & 5 & 9 & 4 & 6 & 9 & 5 & & & 80 & 26 \\
\hline $\begin{array}{l}\text { Oik. fusiformis } \\
\text { f. cornutogastra }\end{array}$ & & & & & & & & & & & & & & & & & & & & & & & 7 & $*$ \\
\hline Oik. gracilis & & & & & & & & & & & & & & & & & 1 & 1 & 2 & & & & 4 & 4 \\
\hline Oik. gracilioides & 1 & 1 & 2 & & & & & & 1 & 2 & 1 & & 1 & & & 2 & & 2 & & 2 & & & 24 & 5 \\
\hline oik. dioica & & & & & & & & & & & & & & & & & & & & & & & 24 & 10 \\
\hline Oik. rufescens & 2 & & & & 4 & 6 & 6 & & 9 & & 8 & 1 & & & 4 & 4 & 1 & 1 & 1 & 12 & 1 & & 48 & 11 \\
\hline Oik. parva & & & & 1 & & 3 & & & & & & & & & & & & & & 1 & & & 4 & 6 \\
\hline Oik. cophocerca & 6 & & & 1 & 1 & 4 & & & 2 & 2 & 4 & 1 & 1 & 1 & 2 & 1 & & & & 2 & 1 & & 29 & 6 \\
\hline Oik. albicans & 3 & 1 & & 2 & & 6 & & & 10 & & & & & & 9 & & & & & & & & 10 & 12 \\
\hline Oik. labradoriensis & & & & & & & & & & & & & & & & & & & & & & & 12 & 31 \\
\hline $\begin{array}{l}\text { Oikopleura spp. } \\
\text { Damaged specimens or juv. }\end{array}$ & 6 & 1 & 3 & 1 & & 6 & 1 & 1 & 1 & 3 & 2 & 5 & 8 & 7 & 36 & 12 & 4 & 2 & 12 & 30 & 3 & 1 & 84 & 12 \\
\hline Meg. huxleyi & & & & & & & & & & & & & & & 1 & & & & & $? 1$ & & & 16 & 1 \\
\hline Steg. magnum & & 1 & & & & 8 & 3 & & 2 & 2 & 2 & & & & 1 & & 1 & 2 & & 8 & & & 29 & 5 \\
\hline Alth. tumida & & & & & & & & & & & & & & & & & & & & & & & 1 & 1 \\
\hline Frit. haplostoma & & & & & & & & & & 1 & 2 & 1 & & & & & 2 & & & 31 & & & 16 & 5 \\
\hline Frit. abjornseni & & & & & & & & & & & & & & & & & & & & & & & 2 & 1 \\
\hline Frit. aberrans & & & & & & & & & & & & & & & 3 & & & & & & & & 1 & 4 \\
\hline Frit. formica f. digitata & 1 & & & & & & & & 2 & & 2 & & & & 1 & 2 & 2 & 2 & & & & & 27 & 3 \\
\hline Frit. pacifica & & & & & & & & & & & & & & & 1 & & & & & & & & 1 & 1 \\
\hline Frit. pellucida & & & & & & & & & 1 & 2 & & & & & 1 & & & 2 & 3 & & & & 22 & 7 \\
\hline Frit. borealis f. typica & $? 2$ & & & & & & & & & & & & & & . & & & & & & & & 18 & 14 \\
\hline $\begin{array}{l}\text { Frit. borealis f. sargassi } \\
\text { Larger individuals } \\
\text { Smaller individuals }\end{array}$ & $\overline{1}$ & & 1 & & & 3 & & & $\begin{array}{l}3 \\
4 \\
\end{array}$ & 3 & 1 & 1 & $\overline{7}$ & 1 & & $\begin{array}{l}1 \\
6\end{array}$ & & $\begin{array}{l}2 \\
2 \\
2\end{array}$ & $\overline{9}$ & 11 & & & 61 & 10 \\
\hline Frit. megachile & & & & & & & & & & & & & 3 & & & & & & & & & & 2 & 8 \\
\hline $\begin{array}{l}\text { Fritillaria spp. } \\
\text { Damaged specimens or juv. }\end{array}$ & & & & & & & & & 1 & & & & & & 1 & 1 & 1 & 3 & 4 & 7 & & & 18 & 3 \\
\hline Tect. fertilis & & & & & & & & & & & & & & & & & & & 1. & & & & 17 & 2 \\
\hline App. sicula & 1 & 1 & & & & & & & & & & & & & & & & & & & & & 21 & 3 \\
\hline Kow. tenuis & & & & & & & & & & & & & & & & & & & & & & & 1 & * \\
\hline Total number & 40 & 6 & 10 & 7 & 6 & 43 & 19 & 1 & 41 & 18 & 32 & 16 & 22 & 12 & 85 & 44 & 17 & 26 & 54 & 116 & 8 & 3 & \multirow{2}{*}{\multicolumn{2}{|c|}{$\begin{array}{c}\text { F.O. } \cdots \text { Frequency } \\
\text { of Occurrence } \\
* \cdots \text { less than } 0.5 \%\end{array}$}} \\
\hline Number of species & 10 & 5 & 4 & 5 & 3 & 7 & 3 & & 10 & 8 & 9 & 5 & 6 & 4 & 11 & 7 & 7 & 9 & 7 & 10 & 3 & 1 & & \\
\hline
\end{tabular}

*TP 131 B large net hauled from $450 \mathrm{~m}$. *ST 89 Stranger: North Pacific 5509-2nd, 23.00.

Appendix Table 6-4. Appendicularians of the Transpac Expedition. 


\section{$7-1$}

\begin{tabular}{|c|c|c|c|c|c|c|c|c|c|c|c|c|c|c|c|c|c|c|c|c|c|c|c|c|c|}
\hline Stations & TP 1 & TP 3 & TP 4 & $\operatorname{TP} 10$ & TP 12 & TP 13 & TP 14 & TP 16 & TP 17 & TP 59A & TP 69 & TP 70 & TP 74 & TP 76 & TP 78 & TP 79 & TP 80 & TP 81 & TP 82 & TP 83 & ТP 84 & TP 85 & TP 89 & TP 92A & TP 93 \\
\hline $\begin{array}{l}\text { Pyrosoma atlanticum atlanticum } \\
\text { small colonies }\end{array}$ & & & & & & & & & & & & & & & & & & & & & & 1 & & & \\
\hline Cyclosalpa floridana & & & & & & & & & & & & & & & & & & & & & & & & & \\
\hline Brooksia rostrata & & & & & & & & & & & & & & g. 19 & & & & & & & & & & & \\
\hline Salpa cylindrica & & & & & & & & & & & & & & & & g.1 & & & & g. 3 & g. 1 & & & & \\
\hline $\begin{array}{l}\text { Thalia democratica sol. } \\
\text { sol. var. orientalis }\end{array}$ & $\begin{array}{c}- \\
\text { g. } 5 \\
\end{array}$ & & $\begin{array}{c} \\
\text { g.7 }\end{array}$ & & & & & & & & & & & $\begin{array}{c}\overline{-} \\
\text { g. } 24 \\
\end{array}$ & & & $\frac{1}{\text { g. } 1}$ & $\overline{1}$ & $\begin{array}{c}- \\
\text { g. } 2 \\
\end{array}$ & & & & $\begin{array}{l}\overline{-} \\
\text { g. } 1\end{array}$ & & \\
\hline Doliolum denticulatum & & & & & & & & & & & & & & 5 & & 2 & & & 1 & 3 & & 1 & & & 2 \\
\hline Doliolum nationalis & & & & & & & & & & & 6 & 1 & 58 & 46 & 59 & & & & & & & & & & \\
\hline $\begin{array}{l}\text { Dolioletta gegenbauri } \\
\text { var. tritonis }\end{array}$ & 416 & & & & & & 5 & 5 & 7 & 2 & & & 1 & 19 & 2 & & & & & & & 3 & & & 3 \\
\hline Doliolina spp. & 2 & 418 & & 12 & 4 & & & & & & & & & 9 & & 1 & & & 1 & & & & & & 2 \\
\hline Doliolid Amme & 98 & 53 & & & & 5 & 4 & 2 & 1 & 1 & & & & & 2 & & & 1 & & & & & 1 & 1 & \\
\hline Doliolid trophozooid & 29 & 1 & & & & 7 & 9 & 5 & 1 & & & & & & & & & & & & & & & 1 & 1 \\
\hline $\begin{array}{l}\text { Doliolids, damaged individuals } \\
\text { or juv. }\end{array}$ & 24 & 40 & & & & & & 5 & & & & & & 3 & & & 1 & & & & & & & & \\
\hline
\end{tabular}

Doliolids, damaged individual
or juv.

\begin{tabular}{|c|c|c|c|c|c|c|c|c|c|c|c|c|c|c|c|c|c|c|c|c|c|c|c|c|}
\hline \multicolumn{25}{|l|}{$7-2$} \\
\hline Stations & $\widehat{\text { TP } 94}$ & $\longdiv { \text { TP } 9 5 }$ & TP 97 & TP 99 & TP 99' & $\overline{\text { TP } 100}$ & $\widehat{\mathrm{TP}} 101$ & TP 102 & TP 105 & $\overline{\text { TP106 }}$ & TP 108 & TP 109 & TP 113 & TP 115T & TP116 & TP 117 & TP 118] & $|\mathrm{TP} 120|$ & TP 124 & TP 125 & $\overline{5 \mathrm{TP} 128}$ & TP131B & TP 134 & F.O. \\
\hline $\begin{array}{l}\text { Pyrosoma atlanticum atlanticum } \\
\text { small colonies }\end{array}$ & & & & & & & & & & & & & & & & & & & & & & 4 & & 2 \\
\hline Cyclosalpa floridana & & & & & & & & & & & & & & & & & & g. 1 & & & & & & 1 \\
\hline \multicolumn{25}{|l|}{ Brooksia rostrata } \\
\hline Salpa cylindrica & & & & s. 1 & & & & g. 9 & & & & & & & & & & & & & & & & 5 \\
\hline $\begin{array}{l}\text { Thalia democratica sol. } \\
\text { sol. var. orientalis }\end{array}$ & $\overline{1}$ & $\frac{ \pm}{g .+}$ & $\overline{-}$ & $\overline{\frac{-}{\text { g. } 9}}$ & $\overline{\text { g. } 1}$ & & $\overline{1}$ & $\begin{array}{c}\overline{-} \\
\text { g. } 10\end{array}$ & $\overline{1}$ & & & & & $\begin{array}{c}\overline{2} \\
\text { g. } 2\end{array}$ & & $\begin{array}{c}1 \\
2 \\
\text { g. } 24\end{array}$ & $\underset{\text { g. } 10}{\overline{-}}$ & $\frac{-}{\mathrm{g} .1}$ & $\frac{1}{2}$ & $\overline{\frac{}{g}}$ & $\frac{-}{\text { g. } 1}$ & $\begin{array}{r}1 \\
3 \\
-\end{array}$ & & 24 \\
\hline Doliolum denticulatum & & 14 & 1 & & 7 & 3 & & & 1 & & 1 & 1. & 1 & & 1 & & & & & & & & 1 & 16 \\
\hline \multicolumn{25}{|l|}{ Doliolum nationalis } \\
\hline $\begin{array}{l}\text { Dolioletta gegenbauri } \\
\text { var. tritonis }\end{array}$ & & & & & & & & & & & $? 2$ & 1 & & & & & & & & & & & & 12 \\
\hline Doliolina spp. & 2 & & 1. & 1 & & & & & & & & 2 & & & & & & & & & & & & 12 \\
\hline Doliolid Amme & & & & & & 2 & & & 1 & 1 & & 1. & & & & & & & & & & & & 15 \\
\hline Doliolid trophozooid & 1 & & & & & 5 & & & 2 & & & 1 & & & & & & & & & $\mathrm{C}$ & & & 13 \\
\hline 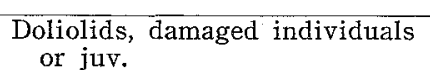 & & & 1 & & & & & & & & & & & & & & & & & & & & & 6 \\
\hline
\end{tabular}

Dolionids, damaged indurduals
or juv. 


\begin{tabular}{|c|c|c|c|c|c|c|c|c|c|c|c|c|c|c|c|c|c|c|c|c|c|c|c|c|c|c|c|c|c|}
\hline \multirow{2}{*}{ Stations } & \multicolumn{3}{|c|}{ MP 1} & \multicolumn{2}{|c|}{ MP 2} & \multicolumn{9}{|c|}{ MP 3} & \multicolumn{3}{|c|}{ MP 5} & \multicolumn{2}{|c|}{ MP 7} & \multicolumn{3}{|c|}{ MP 8} & \multicolumn{7}{|c|}{ MP 10} \\
\hline & $\mathrm{J} 1$ & $\mathrm{~J} 2 \mathrm{~J}$ & $\mathrm{~J} 3$ & $\mathrm{~J} 4:$ & $\mathrm{J} 6$ & $\mathrm{~J} 7$ & J 8. & \begin{tabular}{l|l}
$J$ & $\mathrm{~J}$ \\
$\mathrm{I}$
\end{tabular} & $10 \mid \mathrm{J}$ & {$[11 \mathrm{~J}$} & $\mathrm{J} 12$ & \begin{tabular}{l|l}
$\mathrm{J} 13$ & $\mathrm{~J}$ \\
\end{tabular} & $\begin{array}{lll}\mathrm{J} 14 & \mathrm{~J} \\
\end{array}$ & J15. & $\mathrm{J} 16$ & $\mathrm{~J} 18 \mathrm{~J}$ & $\mathrm{~J} 21$. & \begin{tabular}{l|l}
$\mathrm{J} 23$ & $\mathrm{~J}$
\end{tabular} & & \begin{tabular}{|l|l|}
26 & $\mathrm{~J} 28$ \\
\end{tabular} & \begin{tabular}{|l|l|}
8 & $\mathrm{~J} 30$ \\
\end{tabular} & J 30 & $\mathrm{~J} 32 \mathrm{~J}$ & $\mathrm{~J} 33 \mathrm{~J}$ & & J $35 \mathrm{~J}$ & $\mathrm{~J} 37 \mathrm{~J}$ & $\mathrm{~J} 38 \mathrm{~J}$ & 139] \\
\hline Oik. longicauda & 167 & 377 & 62 & 11 & 22 & 1 & & 17 & 17 & & & 6 & 1 & & & & & 2 & & 8 & & & & 3 & & 54 & 55 & 13 & 22 \\
\hline Oik. intermedia & & & 2 & & & & & & & & & & & & & & & 1 & & & & & & & & & & & \\
\hline Oik. fusiformis & 4 & 23 & & 2 & & 29 & 13 & 36 & 83 & & & 1 & 1 & 2 & 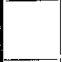 & & & 1 & & & & & & & & 40 & 1 & 1 & 2 \\
\hline $\begin{array}{l}\text { Oik. fusiformis } \\
\text { f. cornutogastra }\end{array}$ & $E$ & & & & & & & 1 & 1 & & & & & & & & & & & & & & & & & & & & \\
\hline Oik. graciloides & 1 & 7 & & & & & & 1 & & & & & & & & & & & & & & & & & & & & & \\
\hline Oik. dioica & & & & 1 & & & & & & & & & & & & & & & & & & & & & & & & & \\
\hline Oik. rufescens & 2 & 19 & 2 & 2 & 2 & 59 & 48 & 22 & 27 & & & 2 & & & & & & & & 1 & & & 3 & 3 & 9 & 16 & & & \\
\hline Oik. parva & & & & & & & & & & & & & & & & & & & & & & & . & 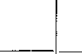 & & 4 & & & \\
\hline Oik. cophocerca & 30 & 53 & 5 & 14 & 2 & & & & & 1 & & & & & & & & 1 & & & & & 1 & 1 & & 10 & & 2 & 2 \\
\hline Oik. albicans & & & 3 & & & & & & & & & 5 & & 2 & & & & & & & & & & & & & & & \\
\hline $\begin{array}{l}\text { Oikopleura spp. } \\
\text { Damaged specimens or juv. }\end{array}$ & 157 & 163 & 58 & 1 & & 28 & 25 & 125 & 71 & 1 & & 15 & 7 & & & & 1 & 5 & & 157 & 1 & 2 & 1 & 3 & 51 & 1072 & 297 & 69 & 50 \\
\hline Meg. huxleyi & & & 1 & & & & & & & & & & & & & & & 2 & & 3 & & & 2 & & & & & & \\
\hline Meg. abyssorum & & & & & & & & & & & & & & & & & & t & & & & & & 1 & & & & & \\
\hline Steg. magnum & & & & & & & & 1 & 1 & & & & 1 & 2 & & & & 2 & & 24 & & & & & & & & & \\
\hline Alth. tumida & & & $? 1$ & & & & & & & & & & & & & & & & & & & & & & & & & & \\
\hline Frit. haplostoma & & 1 & & & & & & & 3 & & & & & & & & & & & 1 & & & & & & & & & \\
\hline Frit. aberrans & & & & & & & & & & & & & 1 & & & & & & & & & & & & & & & & \\
\hline Frit. formica f. digitata & 16 & 21 & & & & & & 18 & 8 & & & 1 & & & & & & & & & & & & & & & & 3 & \\
\hline Frit. fraudax & & & & & & & & & & & & & & & & & & & & & & & & & & & & 1 & \\
\hline Frit. gracilis & & 1 & & & & & & & & & & & & & & & & & & & & & & & & 2 & & & \\
\hline Frit. pellucida & 1 & 9 & & & & & & & & 1. & & & & & & & & & & & & & & & & 1 & & & \\
\hline $\begin{array}{l}\text { Frit. borealis f. sargassi } \\
\text { Larger individuals } \\
\text { Snaller individuals }\end{array}$ & 3 & $\underline{2}$ & & & & $-\overline{4}$ & $\overline{7}$ & $\overline{63} 4$ & $\begin{array}{r}1 \\
486 \\
\end{array}$ & & & $\overline{1}$ & 1 & & & & & & & & & & & & & $\begin{array}{l}1 \\
2 \\
-\end{array}$ & -1 & 1 & \\
\hline Frit. megachile & & & & & & & & & & & & & & & & & & & & & & & & & & & & & \\
\hline Frit. tenella & & & & & & & & & & 1 & & & & & & & - & & & & & & & & & & & & \\
\hline Frit. venusta & & & & & & & & & & & & & & & & & 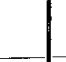 & & & & & & & & & & & & \\
\hline $\begin{array}{l}\text { Fritillaria spp. } \\
\text { Damaged specimens or juv. }\end{array}$ & & & & & & & & & & & & & & & & & & & & & & & & & & & & 2 & \\
\hline Tec. fertilis & & & & & & & & & & & & & & & & & & & & & & & & & & & & & \\
\hline App. sicula & & 1 & & & & & & & 1 & & & & & & & & & & & & & & & & & & & & \\
\hline Total Number & 381 & 677 & 145 & 31 & 30 & 121 & 932 & 2846 & 699 & 4 & 0 & 31 & 12 & 10 & 0 & 0 & 1 & 14 & 181 & $194 \quad 0$ & 1 & 2 & 7 & 11 & 1423 & $237 \quad 35$ & 354 & $92 \quad 7$ & 76 \\
\hline Number of species & 8 & 11 & 10 & 5 & 4 & 4 & 3 & 8 & 9 & 3 & -1 & 6 & 5 & 4 & - & - & -1 & 6 & 3 & $5-$ & -1 & -1 & 3 & 4 & 1 & 8 & 3 & 6 & 3 \\
\hline
\end{tabular}




\begin{tabular}{|c|c|c|c|c|c|c|c|c|c|c|c|c|c|c|c|c|c|c|c|c|c|c|c|c|c|c|c|}
\hline \multirow{2}{*}{ Stations } & \multicolumn{5}{|c|}{ MP 12} & \multirow{2}{*}{ MP14 } & \multirow{2}{*}{$\frac{\mathrm{MP} 15}{\mathrm{~J} 47}$} & \multicolumn{2}{|c|}{ MP 16} & \multicolumn{2}{|c|}{ MP17 } & \multicolumn{4}{|c|}{ MP 18} & \multicolumn{5}{|c|}{ MP 20} & \multirow{2}{*}{\multicolumn{2}{|c|}{$\frac{\text { MP 35 }}{\mathrm{J} 69}$}} & MP36 & \multicolumn{2}{|c|}{ MP 41 } & \multirow{2}{*}{ F.O. } & \multirow{2}{*}{$\begin{array}{c}\text { Mean } \\
\text { percentage }\end{array}$} \\
\hline & \begin{tabular}{|l|l|l}
$\mathrm{J} 40$ & $\mathrm{~J}$ \\
\end{tabular} & $\mid 41$ & $\mathrm{~J} 42$ & $\mathrm{~J} 43$ & & & & $\mathrm{~J} 48 \mathrm{~J}$ & & $\mathrm{~J} 51 \mid \mathrm{J}$ & & J55:J & & \begin{tabular}{l|l}
57 & $\mathrm{~J}$
\end{tabular} & $57[\mathrm{~J}$ & J62 J & J 64. & [64. J & $65 \mid \mathrm{J}$ & $\mathbf{J} 66 \mathrm{~J}$ & & & $\mathrm{~J} 70 \mid \mathrm{J} 7$ & & $73|\mathrm{~J} 74|$ & & \\
\hline Oik. longicauda & 22 & 1 & & 3 & 64 & 13 & 46 & & & & & 14 & 1 & & 50 & 6 & & 23 & 59 & 16 & 30 & 81 & 14 & & 7 & 67 & 27 \\
\hline Oik. intermedia & & & & & & & 4 & & & & & & & & & & & & & & 1 & 1 & 1 & & & 11 & 3 \\
\hline Oik. fusiformis & 6 & & & & 1 & & 32 & & & & & 2 & & & 10 & 8 & & 10 & 53 & 29 & 1 & 8 & 4 & & 2 & 54 & 9 \\
\hline $\begin{array}{l}\text { Oik. fusiformis } \\
\text { f. cornutogastra }\end{array}$ & & & & & & & & & & & & & & & 11 & & & & & 1 & & & & & 1 & 9 & 1 \\
\hline Oik. gaciloides & & & & & & & & & & & & & & & 7 & & & & & & & & & & & 9 & 1 \\
\hline Oik. dioica & & & & & & & 5 & & & & & & & & & & & & & & & & & & & 4 & 3 \\
\hline Oik. rufescens & 3 & & & & 13 & 7 & 21 & & & 1 & & & & & 14 & & & 2 & 16 & 12 & 1 & 1 & 3 & & 4 & 53 & 13 \\
\hline Oik. parva & & & & & & & 1 & & & & & & & & 3 & & & 1 & & & & & & & & 7 & 1 \\
\hline Oik, cophocerca & & & & & 2 & 3 & 29 & 1 & & & & 1 & & 1 & 12 & 6 & & 5 & 19 & 4 & 1 & 14 & 3 & & 1 & 49 & 12 \\
\hline Oik. albicans & & & & & & & 2 & & & & & & & & 1 & & & & & & 1 & & & & & 11 & 7 \\
\hline $\begin{array}{l}\text { Oikopleura spp. } \\
\text { Damaged specimens or juv. }\end{array}$ & 15 & 1 & & 2 & 28 & 17 & 38 & & & 2 & & 7 & 2 & 27. & 103 & 22 & 4 & 34 & 43 & 65 & 45 & 16 & 12 & & $54 \quad 13$ & 82 & 45 \\
\hline Meg. huxleyi & & & & & 1 & 11 & 1 & & & & & & & & 2 & & & 1 & 5 & 1 & 1 & & & 1 & & 25 & 8 \\
\hline Meg. abyssorum & & & & & & & & & & & & & & & & & & & 1 & & & & & & & 2 & 9 \\
\hline Steg. magnum & & & & & $? 1$ & 2 & 5 & & & & & & & 2 & & & & 3 & 14 & 4 & & 1 & 3 & 2 & 1 & 32 & 6 \\
\hline Alth. tumida & & & & . & & & & & & & & & & & & & & & & & & & & & & 2 & 1 \\
\hline Frit. haplostoma & & & & & & & 14 & & & & & & & & 7 & & & 2 & 1 & 2 & 1 & & & & & 16 & 2 \\
\hline Frit. aberrans & & & & & & & & & & & & & & & & & & & & & & & & & & 4 & 7 \\
\hline Frit. formica f. digitata & & & & & 1 & & 3 & & & & & & & & 2 & & & & & 3 & & & 1 & & 4 & 21 & 3 \\
\hline Frit. fraudax & & & & & & & & & & & & & & $? 2$ & 1 & & & 1 & & 1 & & & & & 1 & 12 & 2 \\
\hline Frit. gracilis & & & & & & & & & & & & & & & & & & 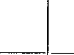 & 1 & & & & & & 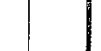 & 5 & * \\
\hline Frit. pellucida & & & & & & & 9 & & & & & & & & 1 & 1 & & 2 & 4 & & & 1 & 2 & & 1111 & 25 & 4 \\
\hline $\begin{array}{l}\text { Frit. borealis f. sargassi } \\
\text { Larger individuals } \\
\text { Smaller individuals }\end{array}$ & -1 & & & & & & 8 & & & $\overline{1}$ & & -1 & & $? 1$ & & 17 & 1 & 7 & 10 & 8 & & $\begin{array}{l}4 \\
4 \\
\end{array}$ & $\overline{2}$ & & $\begin{array}{lll}3 & - & \\
6 & 4 & \end{array}$ & 49 & 10 \\
\hline Frit. megachile & & & & & & & & & & & & & & & & & & & & & & & & & & 2 & 3 \\
\hline Frit. tenella & & & & & 1 & & & & & & & & & & & & & 2 & & 2 & & & & & & 7 & 7 \\
\hline Frit. venusta & & & & & 3 & & & & & & & & & & & & & 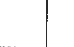 & & & & & 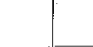 & & & 2 & 3 \\
\hline $\begin{array}{l}\text { Fritillaria spp. } \\
\text { Damaged specimens or juv. }\end{array}$ & & & & & 2 & & & & & 1 & & & & 1 & & & & 3 & 1 & 4 & 2 & & 2 & & 3 & 21 & 4 \\
\hline Tec. fertilis & & & & & & & 1 & & & & & & & & & & & & & & & & & & & 2 & * \\
\hline App. sicula & & & & & & & & & & & & & & & & & & 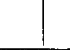 & & & & & & & & 4 & * \\
\hline Total number & 47 & 2 & 0 & 5 & 117 | & 53 & 219 & 1 & 0 & 5 & 0 & 25 & 3 & $\begin{array}{ll}36 & 2 \\
\end{array}$ & 225 & 60 & 5 & 96 & 2261 & 152 & 84. & 58 & 47 & & $93|31|$ & & ency \\
\hline Number of species & 4 & 1. & - & 1 & 9 & 5 & 15 & 1 & -1 & 2 & 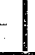 & 4 & 1 & 5 & 14 & 5 & 1 & 12 & 10 & 12 & 8 & 8 & 9 & & 87 & & han 0.5 \\
\hline
\end{tabular}


$9-1$

\begin{tabular}{|c|c|c|c|c|c|c|c|c|c|c|c|c|c|c|c|c|c|c|c|c|c|c|}
\hline \multirow{2}{*}{ Stations } & \multicolumn{2}{|c|}{ MP1 } & \multicolumn{2}{|c|}{ MP 2} & \multicolumn{4}{|c|}{ MP 3} & \multicolumn{3}{|c|}{ MP 5} & \multicolumn{2}{|c|}{ MP 7} & \multicolumn{4}{|c|}{ MP 8} & \multicolumn{5}{|c|}{ MP 10} \\
\hline & $\mathrm{J} 1$ & $\mathrm{~J} 3$ & $\mathrm{~J} 4$ & $\mathrm{~J} 6$ & J 11 & $\mathrm{~J} 12$ & J13 & $\mathrm{J} 14$ & $\mathrm{~J} 16$ & $\mathrm{~J} 18$ & $\mathrm{~J} 21$ & $\mathrm{~J} 23$ & $\mathrm{~J} 25$ & $\mathrm{~J} 26$ & $\mathrm{~J} 28$ & $\mathrm{~J} 30$ & $\mathrm{~J} 30$ & $\mathrm{~J} 32$ & $\mathrm{~J} 33$ & $\mathrm{~J} 34$ & $\mathrm{~J} 35$ & $\mathrm{~J} 38$ \\
\hline $\begin{array}{l}\overline{p y r o s o m a} \text { atlanticum attanticum } \\
\text { small colonies }\end{array}$ & & & & & & & & & & 2 & & 3 & & 1 & 2 & 18 & 33 & & 3 & & & \\
\hline 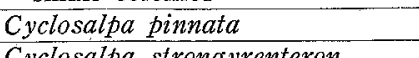 & & & & & & & & & & & 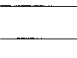 & & & - & 817 & g. 1 & & 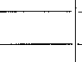 & & & & \\
\hline $\begin{array}{l}\text { Cyclosalapa sisongyrenteron } \\
\text { Cyclosalpa sp. }\end{array}$ & & + & E & & & & 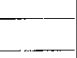 & & & & & 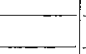 & & - & 8.17 & s. 1 & 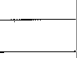 & 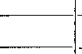 & 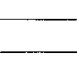 & & 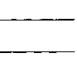 & \\
\hline $\begin{array}{l}\text { Brookssia rostrata } \\
\text { Ritteriella } \\
\text { amboinensis }\end{array}$ & 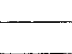 & & 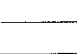 & 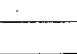 & 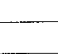 & & 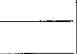 & & ?s.1 & 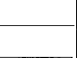 & s. 1 & s. 2 & & 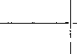 & & 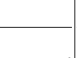 & 5.1 & 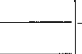 & & & & 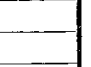 \\
\hline $\begin{array}{l}\text { Metcalfina hexagona } \\
\text { Salpof }\end{array}$ & & & & + & & & & & & & g.1 & 8.8 & s. 2 & & & & & $g .2$ & & & & \\
\hline 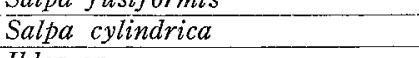 & & & $5.3, g .6$ & + & & & & & & & & & & 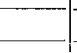 & & 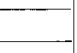 & 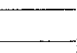 & & & & & \\
\hline $\begin{array}{l}I h i \\
I a s\end{array}$ & & & & & & & & & & ? s. 1 & Q.5 & 8,10 & & $\sqrt{9.3}$ & 5.2 .9 .1 & $\infty 7$ & $\alpha, 1$ & & & & & 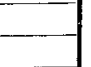 \\
\hline $\begin{array}{l}\text { Thalia democratica sol. } \\
\text { sol. var. orientalis }\end{array}$ & & & & 1 & & & & & & & $\overline{1}$ & & & & & $\frac{1}{1}$ & & 3 & $\begin{array}{r}1 \\
33\end{array}$ & 10 & & 2 \\
\hline $\begin{array}{l}\text { Pegea confoederata } \\
\text { Pation }\end{array}$ & - & 3 & & & & & & & & & & & & & & & & 8 & 1 & & 1 & \\
\hline cilatatum & & & & & & & & & & & & 5 & 4 & 6 & 1 & 14 & 1 & & & & 1 & \\
\hline $\begin{array}{l}\text { Doliolina spp. } \\
\text { Doliolid Amme }\end{array}$ & 2 & 12 & $\begin{array}{r}9 \\
81\end{array}$ & $\frac{1}{6}$ & 7 & 1 & 1 & 3 & & 3 & 3 & 15 & 10 & 5 & & 15 & 6 & - & 2 & & $\frac{1}{3}$ & \\
\hline noe & & & & & & & & & & & & & & & & & & & & & & \\
\hline $\begin{array}{l}\text { Doliolids, damaged ind } \\
\text { or juv. }\end{array}$ & & & & & & & & & & & & & & & & & 2 & & & & & 1 \\
\hline
\end{tabular}

$$
\text { 9-2 }
$$

\begin{tabular}{|c|c|c|c|c|c|c|c|c|c|c|c|c|c|c|c|c|c|c|c|c|}
\hline \multirow{2}{*}{ Stations } & \multicolumn{3}{|c|}{ MP 12} & \multirow{2}{*}{$\frac{\mathrm{MP} 14}{\mathrm{~J} 46}$} & \multirow{2}{*}{$\frac{\mathrm{MP} 15}{\mathrm{~J} 47}$} & \multicolumn{2}{|c|}{ MP 16} & \multicolumn{3}{|c|}{ MP 18} & \multicolumn{5}{|c|}{ MP 20} & \multirow{2}{*}{\begin{tabular}{|c|} 
MP 35 \\
$\mathrm{J} 69$ \\
\end{tabular}} & \multicolumn{2}{|c|}{ MP 36} & \multirow{2}{*}{\begin{tabular}{|c|}
$\mathrm{MP} 41$ \\
$\mathrm{~J} 73$ \\
\end{tabular}} & \multirow{2}{*}{ F. O. } \\
\hline & $\mathrm{J} 40$ & $\mathrm{~J} 41$ & $\mathrm{~J} 44$ & & & $\mathrm{~J} 48$ & $\mathrm{~J} 50$ & J 55 & $\mathrm{~J} 57$ & J 57 & $\mathrm{~J} 62$ & $\mathrm{~J} 64$ & $J 65$ & $J 66$ & $\mathrm{~J} 67$ & & $\mathrm{~J} 70$ & $\mathrm{~J} 71$ & & \\
\hline $\begin{array}{l}\text { Pyrosoma atlanticum atlanticum } \\
\text { small colonies }\end{array}$ & & & & & & & 3 & & & & & & & & & & & & & 14 \\
\hline Cyclosalpa pinnata & & & & s.2, g.6 & & & g. 1 & & & & & & & & & & & & 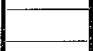 & 5 \\
\hline Cyclosalpa strongyrenteron & & & & & & & & & & & & & & & & & & & & 2 \\
\hline Cyclosalpa sp. & & & & & & & & & & & & & & & & & & & & 2 \\
\hline Brooksia rostrata & 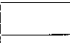 & & & s. 5 & & & & & & & & & & & & & & 8. 1 & & 4 \\
\hline Ritteriella amboinensis & 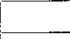 & & & s. 56 & & s. 180, g. 134 & s.15, g.4 & & & & s. 1 & & & 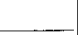 & & 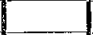 & & & - & 14 \\
\hline Metcalfina haxagona & & & & & & & & & & & & & & & & & & & & 2 \\
\hline Salpa fusiformis & E & & & & & & & & & & & & & 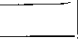 & & & & & & 4 \\
\hline Salpa cylindrica & & & & s.8, g. 9 & & & & & 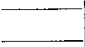 & - & & & & - & & & & & 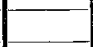 & 5 \\
\hline Ihlea sp. & & & & & & & & & & & & & & & & & & & & 2 \\
\hline Iasis zonaria & & & & $\mathrm{s.2,g.21}$ & 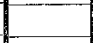 & g. 22 & & & & & & & & & & 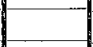 & & & - & 14 \\
\hline $\begin{array}{l}\text { Thatia democratica sol. } \\
\text { sol. var. orientalis }\end{array}$ & & & & $\overline{14}$ & & $\frac{4}{2}$ & $\begin{array}{l}2 \\
5\end{array}$ & $\overline{1}$ & $\overline{1}$ & $\begin{array}{l}1 \\
5\end{array}$ & & $\overline{2}$ & $\overline{1}$ & $\overline{3}$ & $\stackrel{2}{-}$ & & & $\overline{1}$ & $\overline{1}$ & 34 \\
\hline Pegea confoederata & & & & & & & & & & & & & & & & & & & & 2 \\
\hline Doliolum denticulatum & 4 & 1 & 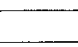 & & 7 & & & & - & 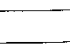 & & & & 1 & 1 & 1 & 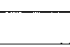 & - & & 18 \\
\hline Doliolina intermedia & & & & & & & & & - & - & & & & & & & & & & 10 \\
\hline Doliolina spp. & & & & & & & & & & & & & & & & & & 1 & & 7 \\
\hline Doliolid Amme & & & 1 & 149 & 5 & 2 & & & 1 & & & 6 & 16 & 5 & 4 & 3 & 2 & 12 & 3 & 54 \\
\hline Doliolid trophozooid & & & & & & & & & & & & & & 2 & & & & & & 2 \\
\hline $\begin{array}{l}\text { Doliolids, damaged individuals } \\
\text { or juv. }\end{array}$ & & & & & & & & & & & & & & & & & & & & 4 \\
\hline
\end{tabular}

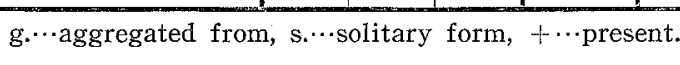


10

\begin{tabular}{|c|c|c|c|c|c|c|c|}
\hline Stations & $\begin{array}{l}\mathrm{EQP} \\
\mathrm{S} 28\end{array}$ & $\begin{array}{l}\mathrm{EQP} \\
\mathrm{H} 3\end{array}$ & $\begin{array}{l}\mathrm{EQP} \\
\mathrm{H7}\end{array}$ & $\begin{array}{l}\text { EQP } \\
\text { H11 }\end{array}$ & $\begin{array}{l}\mathrm{EQP} \\
\mathrm{H} 17\end{array}$ & F.O. & $\begin{array}{c}\text { Mean } \\
\text { percen- } \\
\text { tage }\end{array}$ \\
\hline Oik. longicauda & 354 & 19 & 5 & 414 & 64 & 100 & 22 \\
\hline Oik. intermedia & & & & 3 & 15 & 40 & 1 \\
\hline Oik. fusiformis & 40 & 14 & 3 & 88 & 38 & 100 & 7 \\
\hline $\begin{array}{l}\text { Oik. fusiformis } \\
\text { f. cornutogastra }\end{array}$ & & & & & 1 & 20 & * \\
\hline Oik. graciloides & & 1 & & & 1 & 40 & 1 \\
\hline Oik. rufescens & 20 & 3 & 2 & 44 & 131 & 100 & 7 \\
\hline Oik. cophocerca & 3 & 3 & & 3 & 32 & 80 & 2 \\
\hline Oik. albicans & & & & 5 & & 20 & 1 \\
\hline $\begin{array}{l}\text { Oikopleura spp. } \\
\text { Damaged specimens or juv. }\end{array}$ & 75 & 11 & 61 & 356 & 139 & 100 & 26 \\
\hline Meg. huxleyi & & 1 & 5 & 9 & 11 & 80 & 2 \\
\hline Steg. magnum & & & 1 & 22 & 44 & 60 & 3 \\
\hline Pelagopleura sp. & & & & 1 & 1 & 40 & * \\
\hline Alth. tumida & 1 & & & & & 20 & * \\
\hline Bathochordaeus sp. tail & & & & & 1 & 20 & $*$ \\
\hline Frit. haplostoma & 1 & & 1 & & & 40 & 1 \\
\hline Frit. aberrans & 2 & & & & & 20 & * \\
\hline Frit. formica f. digitata & 9 & 2 & & 5 & 4 & 80 & 1 \\
\hline Frit. fraudax & 11 & & & & 2 & 40 & 1 \\
\hline Frit. gracilis & 1 & 3 & & & & 40 & 1 \\
\hline Frit. pacifica & 1 & & & & 25 & 40 & 2 \\
\hline Frit. pellucida & 124 & 73 & 23 & & 15 & 80 & 23 \\
\hline Frit. borealis f. intermedia & 1 & & & & & 20 & $*$ \\
\hline $\begin{array}{l}\text { Frit. borealis f sargassi } \\
\text { Larger individuals } \\
\text { Smaller individuals }\end{array}$ & 36 & $\overline{1}$ & $\begin{array}{l}2 \\
6\end{array}$ & & 22 & 80 & 4 \\
\hline Frit. megachile & 1 & & 1 & & & 40 & 1 \\
\hline Frit. tenella & 246 & 1 & & 5 & 19 & 80 & 8 \\
\hline Frit. venusta & 23 & & 2 & 1 & 25 & 80 & 2 \\
\hline $\begin{array}{l}\text { Fritillaria spp. } \\
\text { Damaged specimens or juv. }\end{array}$ & 10 & & 2 & 1 & 5 & 80 & 1 \\
\hline Tec. fertilis & & & & & 9 & 20 & 1 \\
\hline Total number & 959 & 132 & 114 & 957 & 604 & \multirow{2}{*}{\multicolumn{2}{|c|}{$\begin{array}{l}\text { F.O..... Frequency } \\
\text { of Occurrence }\end{array}$}} \\
\hline Number of species & 17 & 11 & 10 & 12 & 19 & & \\
\hline
\end{tabular}

Appendix Table 10. Appendicularians of the Equapac Expedition
11

\begin{tabular}{|c|c|c|c|c|c|c|}
\hline Stations & $\begin{array}{l}\mathrm{EQP} \\
\mathrm{S} 28\end{array}$ & $\begin{array}{l}\mathrm{EQP} \\
\mathrm{H} 3\end{array}$ & $\begin{array}{l}\mathrm{EQP} \\
\mathrm{H} 7\end{array}$ & $\begin{array}{l}\text { EQP } \\
\text { H11 }\end{array}$ & $\begin{array}{l}\mathrm{EQP} \\
\mathrm{H17}\end{array}$ & F.O. \\
\hline $\begin{array}{l}\text { Pyrosoma atlanticum atlanticum } \\
\text { small colonies }\end{array}$ & & & & 9 & 1 & 40 \\
\hline Pyrosoma vericillatum & & & & 3 & & 20 \\
\hline Cyclosalpa bakeri & & & g. 2 & & & 20 \\
\hline Salpa maxima & s. 2 & & & g. 6 & & 40 \\
\hline Salpa fusiformis & & $\begin{array}{l}\text { s. } 2 \\
\text { g. } 8\end{array}$ & & & g. 1 & 40 \\
\hline Salpa cylindrica & & $\begin{array}{l}\text { s. } 1 \\
\text { g. } 2\end{array}$ & & $\begin{array}{l}\text { s. } 1 \\
\text { g. } 3 \\
\end{array}$ & & 40 \\
\hline Iasis zonaria & & & & g. 1 & & 20 \\
\hline $\begin{array}{l}\text { Thalia democratica sol. } \\
\text { sol. var. orientalis }\end{array}$ & $\begin{array}{r}\overline{1} \\
\text { g. } 2\end{array}$ & $\frac{3}{\text { g. }}$ & & g. $\overline{3}$ & $\begin{array}{r}4 \\
10 \\
\text { g. } 46\end{array}$ & 80 \\
\hline Traustedtia multitentaculata & & & & & g. 1 & 20 \\
\hline Doliolum denticulatum & & & 1 & 19 & 11 & 60 \\
\hline Doliolina undulata & & & & & 1 & 20 \\
\hline Doliolid Amme & 2 & 3 & 7 & 17 & 25 & 100 \\
\hline $\begin{array}{l}\text { Doliolids, damaged individuals } \\
\text { or juv. }\end{array}$ & & & & 1 & & 20 \\
\hline Doliopsis rubescens & & & & & 1 & 20 \\
\hline
\end{tabular}


12

\begin{tabular}{|c|c|c|c|c|c|c|c|c|c|c|c|c|c|c|c|c|c|c|c|c|c|c|c|c|c|c|c|c|c|}
\hline Stations & 1 & 2 & 3 & 4 & 5 & 6 & 7 & 8 & 9 & 10 & 11 & 12 & 13 & 14 & 15 & 16 & 17 & 18 & 19 & 20 & 21 & 22 & 23 & 24 & 26 & 27 & 28 & 29 & F.O. \\
\hline $\begin{array}{l}\text { Pyrosoma atlanticum atlanticum } \\
\text { small colonies }\end{array}$ & & & & & & 1 & & & & & & & & & & & 2 & & & & & & & & & & & & 7 \\
\hline Cyclosalpa pinnata & g. $1^{*}$ & & & $\begin{array}{l}\text { s. } 1 \\
\text { g. } 1\end{array}$ & g. $2^{*}$ & $\begin{array}{l}\text { s. } 1 \\
\text { g. } 5^{*}\end{array}$ & g. 2 & & g. 1 & & & & & & & & & & g. $1 *$ & & & & & & & & & & 25 \\
\hline$\frac{\text { Cyclosalpa affinis }}{\text { Cyclosalba floridana }}$ & & & & & g. 5 & & & & & & & & & & & $\ldots$ & & & $\ldots$ & & & & g. 6 & & & & E. & & 7 \\
\hline $\begin{array}{l}\text { Cyclosapalpa foriadand } \\
\text { Cyclosalpa sp. }\end{array}$ & & & g. 1 & & & & & & & & & & & & & & & & & & & & & & & & $s, 1$ & & $\frac{4}{4}$ \\
\hline Brooksia rostrata & & & & & & & & & s. 1 & & g. 1 & & & & & 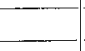 & & & & & & & & & & & s. 6 & & $\frac{4}{11}$ \\
\hline $\begin{array}{l}\text { Ritteriella } \mathrm{sp} \\
\text { Salpa fusiformis }\end{array}$ & & g. 1 & & & s. 2 & & . & & . & & & & g. 6 & & & & & & & & g. 2 & & & & & & s. 2 & & $\frac{4}{41}$ \\
\hline Salpa cylindrica & & g. 1 & g. 1 & & & s. 1 & g. 12 & & g. 4 & & g. 5 & s. 1 & s. 4 & & & & & & g. 1 & & g. 4 & & & s. 2 & s. 1 & & & & $\frac{14}{30}$ \\
\hline Ihlea asymmetrica & & & & & & & & & & & & & $\frac{\text { g. } 10}{\text { g. } 2}$ & & & & & & & & & & & g. 5 & g. 3 & & & & $\frac{39}{4}$ \\
\hline Iasis zonaria & & & & & & & & & & & & $\ldots$ & & g. 1 & & & & & & & & & & & & g. 2 & & & $\frac{4}{7}$ \\
\hline Thetys vagina & & & & & & & & & & & & & & & & & & & & & & & & & & g. 1 & & & 4 \\
\hline $\begin{array}{l}\text { Thalia democratica sol. } \\
\text { sol. var. orientalis }\end{array}$ & g. $\frac{2}{22}$ & $\begin{array}{l}2 \\
- \\
-\end{array}$ & g. $\overline{7}$ & & g. $\frac{1}{4}$ & $\begin{array}{r}5 \\
\text { g. } 12 \\
\end{array}$ & $\begin{array}{r}13 \\
\text { g. } 8\end{array}$ & $\begin{array}{r}\overline{5} \\
\text { g. } 5 \\
\end{array}$ & $\begin{array}{r}2 \\
\text { g. } 5 \\
\end{array}$ & $\begin{array}{r}14 \\
\text { g. } 23 \\
\end{array}$ & $\begin{array}{r}\frac{3}{9} \\
\text { g. } 9\end{array}$ & g. $\frac{2}{11}$ & $\frac{7}{\text { g. }}$ & g. $\begin{array}{r}\overline{2} \\
\text { g. } 25\end{array}$ & & g. $\overline{8}$ & $\begin{array}{r}5 \\
\text { g. } 2 \\
\end{array}$ & & & $\begin{array}{r}- \\
\text { g. } 3\end{array}$ & 1 & $\begin{array}{l}\overline{-} \\
\text { g. } 1\end{array}$ & & $\begin{array}{r}1 \\
\text { g. } 15 \\
\end{array}$ & $\begin{array}{r}\overline{1} \\
\text { g. } 9\end{array}$ & $\begin{array}{r}13 \\
\text { g. } 51\end{array}$ & $\begin{array}{r}22 \\
1 \\
\text { g. } 29 \\
\end{array}$ & $\begin{array}{r}1 \\
4 \\
\text { g. } 5\end{array}$ & $\left.\begin{array}{l}25 \\
50 \\
75\end{array}\right\} 82$ \\
\hline Pegea confoederata & & & & & s. 3 & & & & & & & & & g. 3 & & & & & & & & & & & & & & & 7 \\
\hline $\begin{array}{l}\text { Traustedtia multitentaculata } \\
\text { Traustedtia multitentaculata }\end{array}$ & _ & 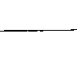 & s. 1 & & $=$ & - & & & & & & & & & & & & & & & & & & & & & & & 4 \\
\hline $\begin{array}{l}\text { var. bicristata } \\
\text { Doliolum denticulatum }\end{array}$ & 1 & 39 & s. 1 & & & 2 & & & & & 7 & $\frac{4}{4}$ & 1 & & & & & & & & & & & & & & 8 & 3 & 4 \\
\hline $\begin{array}{l}\text { Doliolum denticulatum } \\
\text { Doliolid Amme }\end{array}$ & $\frac{1}{16}$ & 25 & 5 & & 1 & 1 & $\overline{3}$ & 11 & 3 & 8 & 33 & 32 & 1 & 7 & & 2 & 7 & & & 4 & $\overline{10}$ & 8 & & & & 1 & $\frac{8}{20}$ & 35 & $\frac{32}{75}$ \\
\hline Doliopsis rubescens & & & & & & & 1 & & & & 6 & & & & & & & & & & & & & & & & & & 7 \\
\hline
\end{tabular}

* var. polae

Appendix Table 12. Thaliaceans collected by the Syunkotu-maru in the Central Pacific.

13

\begin{tabular}{|c|c|c|c|c|c|c|c|c|c|c|c|c|c|c|c|c|c|c|c|c|c|c|c|c|}
\hline Stations & 4 & 6 & 7 & 9 & 10 & 11 & 18 & 19 & 28 & 34 & 35 & 37 & 40 & 41 & 42 & 45 & 46 & 48 & 49 & 51 & 54 & 55 & 56 & F.O. \\
\hline Cyclosalpa pinnata & & & & & & & & & & & & & & g. 5 & & & & & & & & & & 2 \\
\hline $\begin{array}{l}\text { Thalia democratica var. } \\
\text { orientalis }\end{array}$ & s. 1 & & & & & & & & & & & & & & 9 & & & & & & & & & 4 \\
\hline Doliolum denticulatum & 1 & & & 2 & 1 & 2 & 1 & 1 & 1 & & & & & & & & & & & 1 & & & & 15 \\
\hline Doliotelta gegenbauri & 1 & 2 & 2 & & & & & & & 1 & 11 & 1 & & 5 & 3 & & 1 & 1. & 1 & 1 & 1 & & 1 & 25 \\
\hline Doliolina sp. & 1 & & & 4 & 3 & 5 & & & & & & & & & E & & & & & & & & & 7 \\
\hline Doliolid Amme & & & & 1 & & 1 & & & & & 2 & 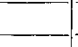 & & & & 1 & & 5 & . & & & 1 & & 11 \\
\hline Doliolid trophozooid & & & & & & & & & & & 1 & & 3 & & & & & 1 & & & & & & 5 \\
\hline
\end{tabular}

Appendix Table 13. Thaliaceans from the Arafura Sea.

\begin{tabular}{|c|c|c|c|c|c|c|c|c|}
\hline Stations & 22 & 24 & 33 & 34 & 35 & 38 & 40 & F.O. \\
\hline Doliolum nationalis & & & & $\overline{1}$ & & 1 & 1 & 12 \\
\hline Doliolina sp. & $? 2$ & & & 1 & & & & 8 \\
\hline $\begin{array}{l}\text { Doliolids, damaged specimens } \\
\text { or juv. }\end{array}$ & & & & 2 & 1 & & & 8 \\
\hline Doliolid Amme & & 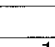 & 1 & 1 & & & & 8 \\
\hline
\end{tabular}

F.O. $\cdots$ Frequency of Occurrence

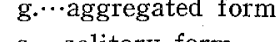

s...solitary form

Appendix Table 14. Thaliaceans from the central part of the tropical Indian Ocean. 
15-1

\begin{tabular}{|c|c|c|c|c|c|c|c|c|c|c|c|c|c|c|c|c|c|c|c|c|c|c|c|c|c|c|c|c|c|c|c|c|}
\hline \multirow{2}{*}{ Stations } & \multicolumn{6}{|c|}{ Division $O$} & \multicolumn{10}{|c|}{ Ryûgâ Inlet } & \multicolumn{6}{|c|}{ Division $\mathrm{P}$} & \multicolumn{7}{|c|}{ Division $\mathrm{L}$} & \multicolumn{3}{|c|}{ Arumizu } \\
\hline & $25 / \mathrm{V}$ & $15 / \mathrm{VI}$ & $3 / \mathrm{VII}$ & $14 / \mathrm{VIII}$ & $10 / \mathrm{IX}$ & $25 / \mathrm{X}$ & $\overline{18 / V}$ & $28 / \mathrm{V}$ & $3 / \mathrm{VII}$ & $6 / \mathrm{VIII}$ & I $30 / \mathrm{VIII}$ & $27 / \mathrm{IX}$ & $25 / \mathrm{x}$ & $\begin{array}{l}\text { Pool } \\
18 / \mathrm{V}\end{array}$ & $\begin{array}{l}\text { red water } \\
28 / \mathrm{V}\end{array}$ & $\begin{array}{c}\text { next inlet } \\
6 / \mathrm{VI} \\
\end{array}$ & $21 / \mathrm{V}$ & $3 / \mathrm{VI}$ & $22 / \mathrm{VII}$ & $30 / \mathrm{VIII}$ & $17 / \mathrm{IX}$ & $25 / \mathrm{z}$ & $15 / \mathrm{V}$ & $15 / \mathrm{V}$ & $31 /$ & $\mathrm{V}_{30 / \mathrm{VI}}^{\text {(east }}$ & II $22 /$ VIII & $\mathrm{I} \mid 27 / \mathrm{IX}$ & $25 / \mathrm{X}$ & $13 / \mathrm{V}$ & $21 / \mathrm{V}$ & $3 / \mathrm{VI}$ \\
\hline Doliolum denticulatum & & 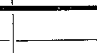 & & & - & & & & & & & & - & & & & - & & & & & & & & & 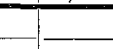 & & & & & & \\
\hline \begin{tabular}{|c} 
Dolioleltta gegenbauri \\
var. tritonis
\end{tabular} & & & & & & & & & & & 0 & & & & . & & & 0 & & 0 & & & $\mathrm{c}$ & $\mathrm{c}$ & & & & & & & & 0 \\
\hline Doliolid Amme & & & & & & & - & 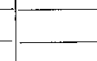 & & & & {[} & & & & & & & & 0 & & & 0 & 0 & & & & & & 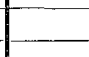 & - - & 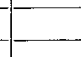 \\
\hline \begin{tabular}{|l|} 
Doliolid trophozooid \\
Oik. longicauda \\
\end{tabular} & 0 & C & 0 & $\mathrm{C}$ & 0 & 0 & $\mathrm{C}$ & $\mathrm{C}$ & 0 & C & C & 0 & 0 & $\mathrm{C}$ & 0 & 0 & 0 & 0 & $\mathrm{C}$ & $\frac{O}{c}$ & 0 & $\mathrm{C}$ & $\frac{O}{\mathrm{CC}}$ & $\frac{O}{\mathrm{CC}}$ & 0 & 5 & $\mathrm{C}$ & 0 & $\mathrm{C}$ & $\mathrm{C}$ & $\mathrm{C}$ & $\mathrm{C}$ \\
\hline Oik. fusiformis & 0 & & & & & & & & & & & & & & & & & & & & & & & & & & & & & & & \\
\hline $\begin{array}{l}\text { Oik. fusiformis } \\
\text { f. cornutogastra }\end{array}$ & & & 0 & 0 & 0 & 0 & 0 & 0 & 0 & 0 & $\mathrm{C}$ & 0 & 0 & 0 & & 0 & 0 & 0 & 0 & $\mathrm{C} \mathrm{C}$ & 0 & $\mathrm{C}$ & 0 & 0 & 0 & 0 & 0 & 0 & 0 & 0 & 0 & 0 \\
\hline Oik. dioica & 0 & O & 0 & 0 & & 0 & $\mathrm{C}$ & 0 & 0 & 0 & 0 & & 0 & 0 & & C & 0 & 0 & 0 & 0 & 0 & 0 & 0 & 0 & 0 & 0 & 0 & & 0 & & 0 & 0 \\
\hline \begin{tabular}{|l|l|} 
Oik. rufescens \\
Oi. rothocerca
\end{tabular} & 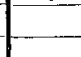 & & 0 & 0 & 0 & 0 & 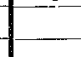 & 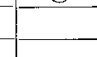 & 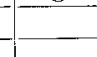 & $\mathrm{C}$ & 0 & 0 & & & & & & & 0 & 0 & & 0 & 0 & 0 & & 0 & 0 & 0 & 0 & 0 & & \\
\hline \begin{tabular}{|l|} 
Oik. cophocerca \\
Steg. magnum
\end{tabular} & & 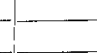 & & & & & & & & & $\ldots$ & - & - & - & & & - & _- & - & - & & - & - & - & _ & - - & & -1 & 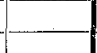 & 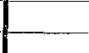 & 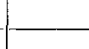 & 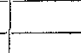 \\
\hline Frit. haplostoma & 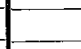 & 0 & 0 & $O$ & & 0 & 0 & 0 & - & 0 & 0 & & 0 & & & & 0 & 0 & - & 0 & 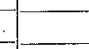 & 0 & $\mathrm{C}$ & 0 & & 0 & & & & & 0 & 0 \\
\hline \begin{tabular}{|l|} 
Frit. abjornseni \\
Frit, formica f.
\end{tabular} & - & - & - & & ـ & & 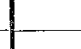 & & & 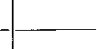 & & & & & & & & & & & & & 0 & & 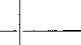 & & & & & & & \\
\hline $\begin{array}{l}\text { Frrt. formica f. algitata } \\
\text { Frit. pellucida }\end{array}$ & & 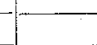 & 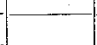 & & & & & & & & & & & & & & & & & & & & & & & & & & & & & \\
\hline $\begin{array}{l}\text { Frit. borealis f. sargassi } \\
\text { Larger individuals } \\
\text { Smaller individuals }\end{array}$ & & & 0 & & & & & & & & & & & & & 0 & 0 & 0 & 0 & & & & & 0 & $\overline{0}$ & & & & & & $\bar{O}$ & \\
\hline $\begin{array}{l}\text { Fritillaria sp. } \\
\text { Damaged specimen }\end{array}$ & & & & & & & & & & & & & & & & & & & & & & & & & & & & & & & & \\
\hline App. sicula & 0 & 0 & 0 & 0 & & & 0 & & O & & 0 & & 0 & & & 0 & 0 & $\mathrm{CC}$ & 0 & 0 & & & 0 & 0 & $\mathrm{C}$ & & 0 & & & 0 & 0 & 0 \\
\hline
\end{tabular}

$15-2$

\begin{tabular}{|c|c|c|c|c|c|c|c|c|c|c|c|c|c|c|c|c|c|c|c|c|c|c|c|c|c|c|c|c|c|c|c|}
\hline \multirow{2}{*}{ Stations } & \multicolumn{6}{|c|}{ Arumizu (continued) } & \multicolumn{5}{|c|}{ Arappu } & \multicolumn{6}{|c|}{ Arakabesan } & \multicolumn{7}{|c|}{ Anchorage } & \multicolumn{2}{|c|}{$\begin{array}{c}\text { Oropusyakaru } \\
\text { Bay }\end{array}$} & \multirow{2}{*}{$\begin{array}{c}\text { Gasupan } \\
\text { Bay }\end{array}$} & \multirow{2}{*}{$\begin{array}{c}\text { off } \\
\text { Aruma- } \\
\text { tenguru }\end{array}$} & \multirow{2}{*}{\begin{tabular}{|c|} 
West \\
Lagoon \\
off \\
Gasupan \\
\end{tabular}} & \multirow{2}{*}{\begin{tabular}{|c|} 
South \\
of \\
Uruku- \\
taberu \\
\end{tabular}} & \multirow{2}{*}{ F.O. } \\
\hline & $27 / \mathrm{VI}$ & | $22 / \mathrm{vII}$ & 14/VIII & $17 / \mathrm{IX}$ & $25 / \mathrm{X}$ & $\left|\begin{array}{|c|}\text { S. Inlet } \\
27 / \mathrm{VI}\end{array}\right|$ & $13 / \mathrm{V}$ & $21 / \mathrm{V}$ & $30 / \mathrm{VII}$ & $25 / \mathrm{X}$ & \begin{tabular}{|} 
Grotto \\
$13 / \mathrm{V}$
\end{tabular} & $18 / \mathrm{V}$ & $31 / \mathrm{V}$ & $15 / \mathrm{VI}$ & $6 / \mathrm{VIII}$ & $10 / \mathrm{IX}$ & $27 / \mathrm{X}$ & $15 / \mathrm{V}$ & $25 / \mathrm{V}$ & $6 / \mathrm{VI}$ & I $22 / \mathrm{VII}$ & $33 / \mathrm{VIII}$ & $17 / \mathrm{IX}$ & $27 / \mathrm{X}$ & $\begin{array}{l}\text { N.W. } \\
\text { Inlet } \\
\end{array}$ & \begin{tabular}{|l|} 
inner- \\
most St
\end{tabular} & & & & & \\
\hline Doliolum denticulatum & & & 0 & & & & & & & & & & & & & & & & & & & & & & & & & & & & $\overline{2}$ \\
\hline $\begin{array}{l}\text { Doliolettta gegenbauri } \\
\text { var. tritonis }\end{array}$ & & & 0 & & 0 & & & & & & & & 0 & 0 & 0 & & 0 & 0 & & 0 & 0 & & & & & & & & & & 24 \\
\hline Doliolid Amme & & & 0 & & - & & & E & & 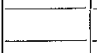 & & & & & 0 & 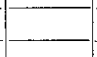 & 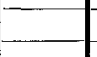 & 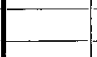 & - & 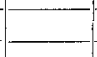 & - & & & 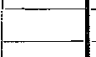 & 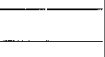 & _ & & & 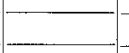 & & 8 \\
\hline $\begin{array}{l}\text { Doliolid trophozooid } \\
\text { Oik. longicauda }\end{array}$ & $\mathrm{C}$ & $\mathrm{C}$ & $\frac{\mathrm{O}}{\mathrm{C}}$ & 0 & $\mathrm{C}$ & 0 & 0 & 0 & $\mathrm{CC}$ & 0 & 0 & $\bar{C}$ & C & 0 & $\mathrm{C}$ & 0 & $\mathrm{C}$ & $\mathrm{C}$ & $\mathrm{CC}$ & $\mathrm{C}$ & $\mathrm{CC}$ & $\mathrm{C}$ & 0 & 0 & $\bar{C}$ & 0 & & & $\mathrm{C}$ & 0 & $\begin{array}{r}6 \\
97\end{array}$ \\
\hline Oik. fusiformis & & & & & & & & & & & & & & & & & & & & & & & & & & & & & & & $\frac{1}{2}$ \\
\hline $\begin{array}{l}\text { Oik. fusiformis } \\
\text { f. cornutogastra }\end{array}$ & 0 & $\mathrm{C}$ & 0 & O & O & & O & 0 & $\mathrm{C}$ & 0 & & $\mathrm{C}$ & C & C & 0 & 0 & $\mathrm{C}$ & 0 & 0 & 0 & $\mathrm{C}$ & $\mathrm{C}$ & 0 & $\mathrm{C}$ & 0 & 0 & & & 0 & & 87 \\
\hline Oik. dioica & - & O & 0 & & & 0 & 0 & 0 & 0 & 0 & 0 & 0 & & 0 & & 0 & 0 & 0 & 0 & $\mathrm{C}$ & 0 & 0 & 0 & 0 & 0 & C & 0 & & 0 & & 81 \\
\hline Oik. rufescens & & 0 & 0 & 0 & C & _ & & & 0 & 0 & & 0 & 0 & 0 & 0 & 0 & 0 & 0 & & 0 & C & c & 0 & O & & & & & 0 & & 58 \\
\hline $\begin{array}{l}\text { Oik. cophocerca } \\
\text { Steg. magnum }\end{array}$ & - & 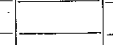 & $\square$ & 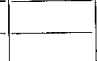 & & 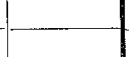 & 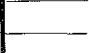 & & - & _ & - & - & 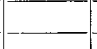 & $i$ & & -1 & 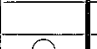 & -1 & & & & 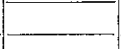 & & $\Omega$ & 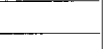 & - & & & 0 & & 2 \\
\hline $\begin{array}{l}\text { Steg. magnum } \\
\text { Frit. haplostoma }\end{array}$ & 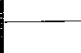 & 0 & 0 & 0 & 0 & & $\mathrm{C}$ & & $\overline{\mathrm{CC}}$ & 0 & & 0 & $\overline{0}$ & 0 & & 0 & 0 & 0 & $\mathrm{C}$ & 0 & $\mathrm{C}$ & 0 & 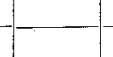 & 0 & 0 & 0 & & & 0 & & $\begin{array}{r}3 \\
60\end{array}$ \\
\hline $\begin{array}{l}\text { Frit. abjornseni } \\
\text { rit. }\end{array}$ & & & & & & & 0 & & & & & & & & & & & 0 & & & & & & & & & & & & & 5 \\
\hline Frit. formica f. digitata & L & 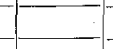 & 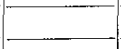 & - & 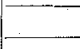 & & & & & & - & E. & & & & & & & & 0 & & & & & & & & & & & 2 \\
\hline Frit. pellucida & & & & & & & 0 & & 0 & _ & 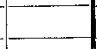 & - & & 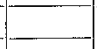 & 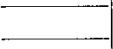 & 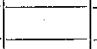 & —. & - & 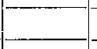 & & & & 0 & 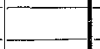 & 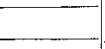 & & & & 0 & & $\frac{6}{6}$ \\
\hline $\begin{array}{l}\text { Frit. borealis f. sargassi } \\
\text { Larger individuals } \\
\text { Smaller individuals }\end{array}$ & & $\overline{\mathrm{C}}$ & & & $\overline{\mathrm{O}}$ & & $\overline{0}$ & & 8 & & & & 0 & 0 & & & $\overline{0}$ & $\overline{0}$ & $\overline{0}$ & $\overline{0}$ & & & & & & & & & $\overline{0}$ & 0 & 32 \\
\hline $\begin{array}{l}\text { Fritillaria sp. } \\
\text { Damaged specime }\end{array}$ & & & & & & & & & & & 0 & & & & & & & & & & & & & & & & & & & & 2 \\
\hline App. sicula & & 0 & 10 & 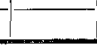 & 0 & & 10 & 0 & 0 & 0 & & 10 & 0 & 0 & 0 & & 01 & 0 & 0 & 0 & 01 & 0 & & $0-1$ & 0 & $\mathrm{O}$ & & & 0 & & 66 \\
\hline
\end{tabular}


$16-1$

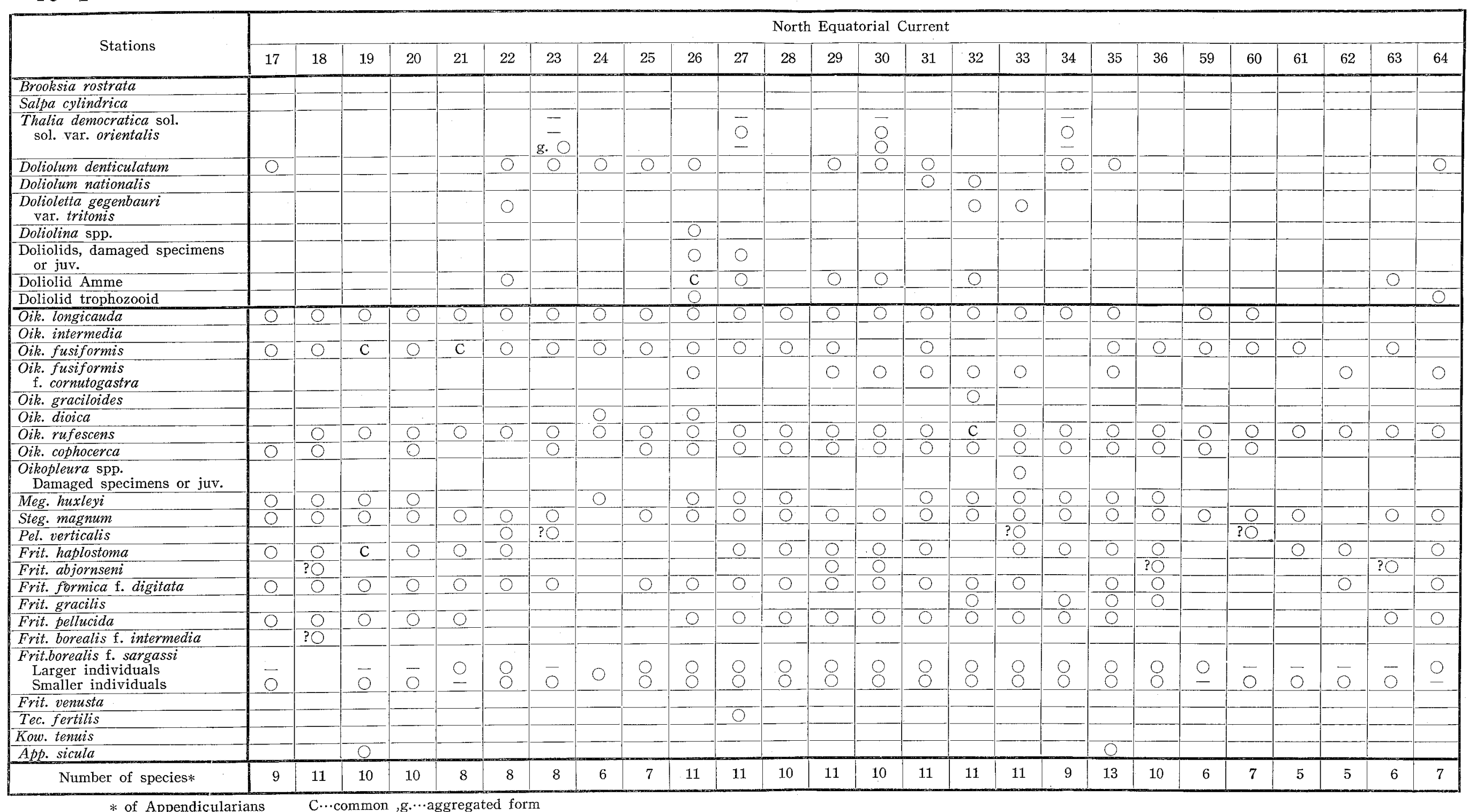

$*$ of Appendicularians

Appendix Table 16-1. Pelagic tunicates occurred in the neighbouring waters of the Palao Islands. 


\section{$16-2$}

\begin{tabular}{|c|c|c|c|c|c|c|c|c|c|c|c|c|c|c|c|c|c|c|c|c|c|c|c|c|c|}
\hline \multirow{2}{*}{ Stations } & \multicolumn{14}{|c|}{ North Equatorial Current } & \multicolumn{8}{|c|}{ Counter Equatorial Current } & \multicolumn{2}{|c|}{$\begin{array}{l}\text { South Equa- } \\
\text { torial Current }\end{array}$} & \multirow{2}{*}{ F.O. } \\
\hline & 65 & 66 & 67 & 68 & 69 & 70 & 71 & 72 & 73 & 74 & 75 & 76 & 14 & 15 & 77 & 78 & 79 & 80 & 83 & 84 & 85 & 86 & 81 & 82 & \\
\hline $\begin{array}{l}\text { Brooksia rostrata } \\
\text { Salpa cylindrica }\end{array}$ & - & 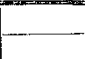 & - & 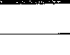 & & & & & & & . & $\ldots$ & g. & g. & & 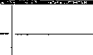 & & g. & 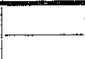 & g. & - & 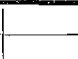 & 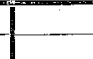 & s. & $\begin{array}{l}8 \\
2\end{array}$ \\
\hline $\begin{array}{l}\text { Thalia democratica sol. } \\
\text { sol. var. orientalis }\end{array}$ & & $\begin{array}{l}= \\
\text { g. } 0\end{array}$ & & & & $\underline{0}$ & & & & & $\underline{0}$ & g. & $\begin{array}{l}\overline{0} \\
\text { g. }\end{array}$ & \begin{tabular}{|c|} 
\\
0 \\
g. \\
\end{tabular} & & $\overline{-}$ & & $\begin{array}{l}- \\
\text { g. } 0\end{array}$ & & & $\begin{array}{l}- \\
\text { g. }\end{array}$ & & & $\begin{array}{c}- \\
\text { g. } \\
\end{array}$ & 28 \\
\hline Doliolum denticulatum & - & & - & 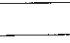 & & & & & & & & & 0 & 0 & 0 & & 0 & 0 & $\mathrm{O}$ & 0 & & & 0 & 0 & 42 \\
\hline Doliolum nationalis & & 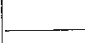 & & 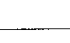 & & & & & & & & & & & & & & & & & & & & & 4 \\
\hline $\begin{array}{l}\text { Dolioletta gegenbauri } \\
\text { var. tritonis }\end{array}$ & & & & & & & & & $? 0$ & & & & & . & & 0 & & 0 & 0 & 0 & 0 & & 0 & O & 22 \\
\hline Doliolina spp. & $\therefore$ & 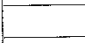 & 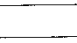 & _ & - & 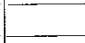 & & & & & - & . & & 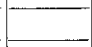 & 0 & & 0 & $? 0$ & 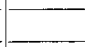 & 0 & 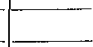 & - & 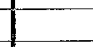 & $? 0$ & 12 \\
\hline $\begin{array}{l}\text { Doliolids, damaged specimens } \\
\text { or juv. }\end{array}$ & & & & & & & & & & & & & & & & & & & & & & & & & 2 \\
\hline Doliolid Amme & & & & & & & & & 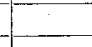 & & & & 0 & 0 & & & 0 & 0 & 0 & 0 & & 0 & 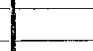 & & 28 \\
\hline Doliolid trophozooid & & & & & & & & & & & & 0 & & & & & & 10 & & 0 & & & & & 6 \\
\hline Oik. longicauda & 0 & 0 & - & 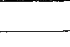 & - & 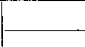 & 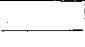 & & - & - & - & 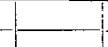 & 0 & 0 & $\mathrm{CC}$ & $\mathrm{C}$ & $\mathrm{C} \mathrm{C}$ & $\mathrm{C}$ & 0 & 0 & 0 & 0 & 0 & 0 & $\frac{70}{2}$ \\
\hline Oik. intermedia & & & & & & & & & & & & & & & & 0 & 0 & 0 & & & & & & & 2 \\
\hline Oik. fusiformis & 0 & 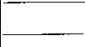 & 0 & 0 & 0 & 0 & 0 & 0 & 0 & & 0 & 0 & & & & & & 0 & 0 & 0 & 0 & 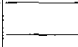 & 0 & 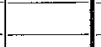 & 70 \\
\hline $\begin{array}{l}\text { Oik. fusiformis } \\
\text { f. cornutogastra }\end{array}$ & & 0 & & & & & & & & 0 & & & 0 & 0 & O & 0 & O & & 0 & & & 0 & & 0 & 38 \\
\hline Oik. graciloides & - & 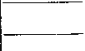 & & - & & & & & & & & & & 0 & & & 0 & & 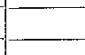 & & & - & & & $\begin{array}{r}6 \\
12\end{array}$ \\
\hline Oik. dioica & 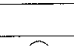 & & & & & & & & & & & & & & & & & 0 & $\bar{\gamma}$ & 0 & & E- & 0 & 0 & 12 \\
\hline Oik. rufescens & 0 & 0 & & 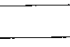 & 0 & & 0 & 0 & 0 & 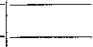 & & 0 & 0 & 0 & 0 & 0 & 0 & 0 & 0 & 0 & 0 & 0 & 0 & 0 & 88 \\
\hline Oik. cophocerca & 0 & 0 & 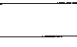 & & & & & 0 & & & 0 & & & & 0 & 0 & 0 & 0 & 0 & 0 & 0 & 0 & 0 & 0 & 64. \\
\hline $\begin{array}{l}\text { Oikopleura spp. } \\
\text { Damaged specimens or juv. }\end{array}$ & & & & & & & & & & & & & & & & & & & & & & & & & 2 \\
\hline Meg. huxleyi & & & & & & - & & & & & & & & 0 & $\mathrm{C}$ & O & & 0 & & 0 & 0 & 0 & 0 & 0 & 46 \\
\hline Steg. magnum & 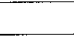 & 0 & - & 0 & & _. & 0 & - & 0 & 0 & & & 0. & 0 & 0 & 0 & 0 & 0 & 0 & 0 & 0 & 0 & 0 & 0 & 82 \\
\hline Pel. verticalis & & & & & & & & & & & & & & & & & 0 & 0 & & & 0 & & & & $14^{-}$ \\
\hline Frit. hapiostoma & 0 & 0 & 0 & 0 & & - & - & 0 & 0 & 0 & 0 & & 0 & _. & 0 & 0 & 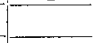 & 0 & 0 & 0 & 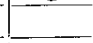 & 0 & - & L & 66 \\
\hline Frit. abjornseni & & & & & & & & & & & & & & & & & & & & & & & & & 10 \\
\hline \begin{tabular}{|l} 
Frit. formica f. digitata \\
Fit.
\end{tabular} & $\mathrm{O}$ & 0. & 0 & . & & - & 0 & - & 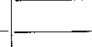 & - & - & 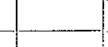 & $\mathrm{O}$ & 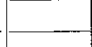 & 0 & 0 & O & 0 & 0 & 0 & - & 0 & 0 & 0 & 68 \\
\hline Frit, gracilis & & & & & & & & & & & & & & & & & & & & & & & & & $\frac{8}{60}$ \\
\hline Frit. pellucida & 0 & 0 & $\mathrm{O}$ & 0 & 0 & 0 & 0 & E & 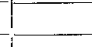 & - & 0 & & - & $\mathrm{O}$ & 0 & 0 & 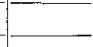 & 0 & 0 & 0 & 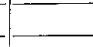 & E. & - & _ & 62 \\
\hline Frit. borealis f. intermedia & & & & & & & & 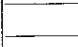 & 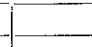 & $=$ & & & 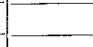 & & 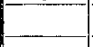 & & 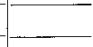 & & & & _ & & 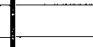 & - & 2 \\
\hline $\begin{array}{l}\text { Frit borealis f. sargassi } \\
\text { Larger individuals } \\
\text { Smaller individuals }\end{array}$ & $\overline{0}$ & $\overline{0}$ & & $\overline{0}$ & & & 0 & $\overline{0}$ & $\overline{0}$ & $\overline{0}$ & 0 & 0 & 0 & 8 & $\overline{0}$ & $\overline{0}$ & $\underline{0}$ & 8 & $\overline{0}$ & $\overline{0}$ & $\overline{0}$ & $\overline{0}$ & $\overline{0}$ & $\bar{o}$ & 92 \\
\hline Frit. venusia & & & & & & & & & & & & & & & 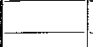 & & & 0 & & & & & & & 2 \\
\hline Tec. fertilis & $\ldots$ & - & & . & & & & & & 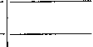 & & & & 0 & 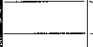 & & 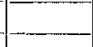 & & & & 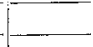 & 0 & 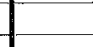 & 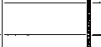 & 6 \\
\hline Kow. tenuis & - & & & & & - & & & & - & 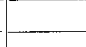 & $\ldots$ & & & & & & & & 0 & 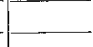 & & & & 2 \\
\hline App. sicula & & & & & & & & & & & & & & & & & 0 & 0 & & & & & 0 & 0 & 12 \\
\hline Number of species* & 8 & 9 & 4 & 5 & 3 & 2 & 6 & 5 & 5 & 4 & 5 & 3 & 7 & 9 & 10 & 11. & 11 & 15 & 10 & 12 & 8 & 10 & 10 & 10 & $\begin{array}{l}\text { F.O..... Frequency } \\
\text { of Occurrence }\end{array}$ \\
\hline
\end{tabular}




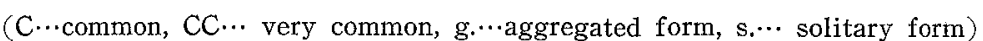

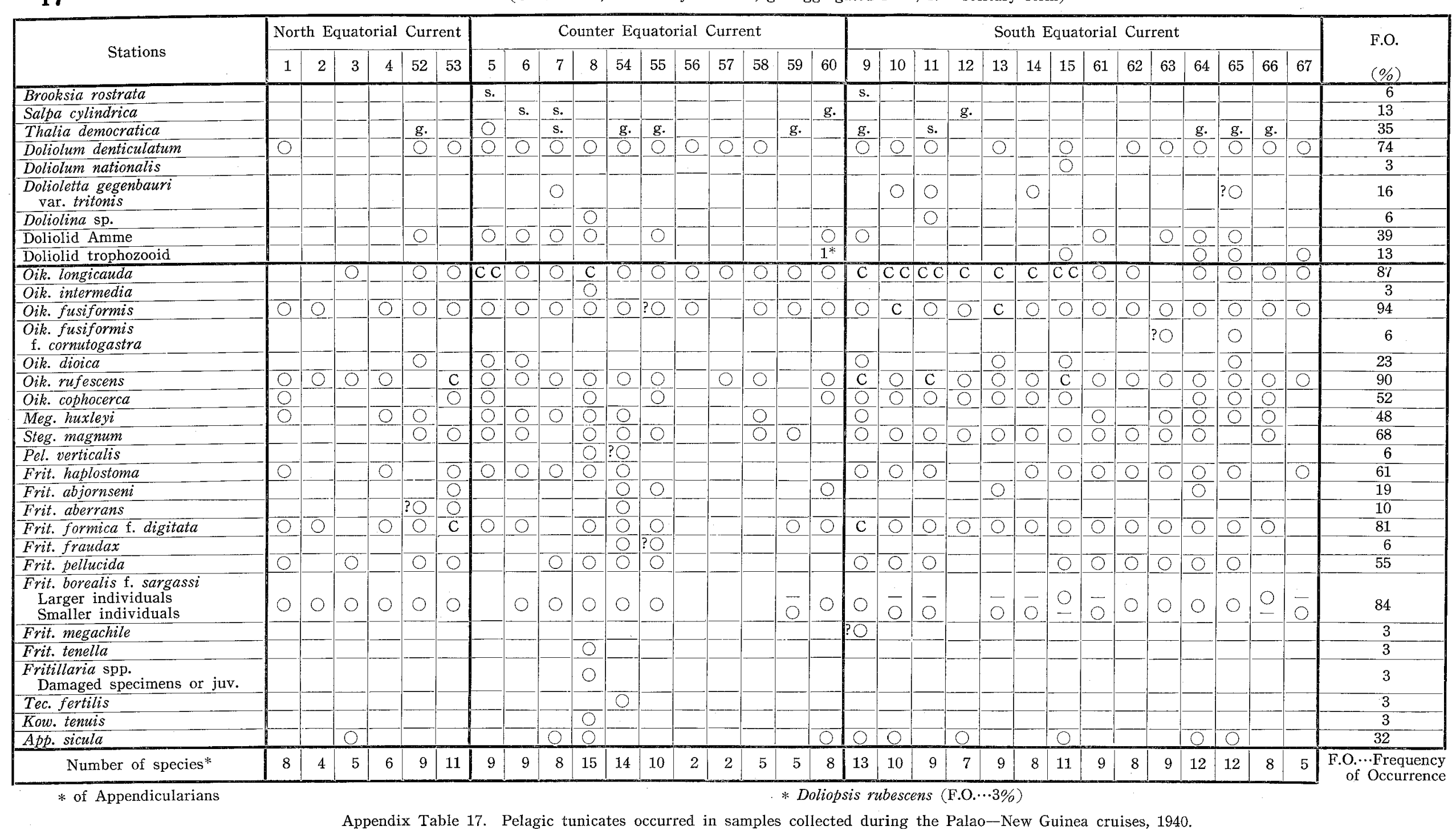

Appendix Table 17. Pelagic tunicates occurred in samples collected during the Palao-New Guinea cruises, 1940. 


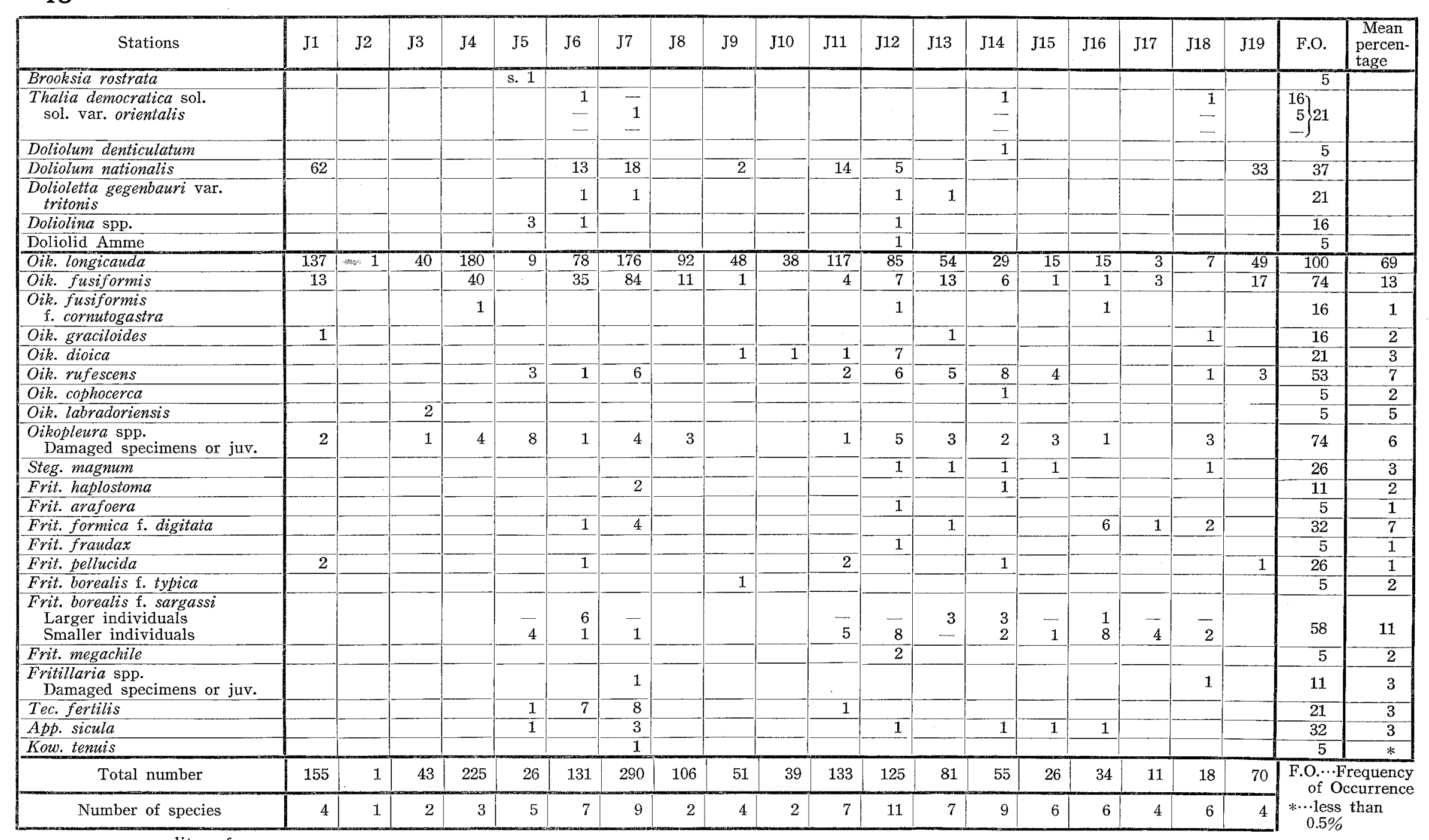

s....solitary form

Appendix Table 18. Pelagic tunicates occurred in samples from the North-Eastern waters of Japan. 
$19-1$

\begin{tabular}{|c|c|c|c|c|c|c|c|c|c|c|c|c|c|c|c|c|c|c|c|c|c|c|c|c|c|c|c|}
\hline \multirow[b]{2}{*}{ Stations } & \multicolumn{6}{|c|}{$\begin{array}{l}\text { More northern waters than } \\
40^{\circ} \mathrm{N} \text {. }\end{array}$} & \multicolumn{6}{|c|}{$\begin{array}{l}\text { Waters off north-eastern Honsyũ, } \\
\text { south to } 40^{\circ} \mathrm{N} \text {. }\end{array}$} & \multicolumn{6}{|c|}{ Sagami Bay } & \multicolumn{9}{|c|}{ Waters off south-western Honsyû } \\
\hline & $\begin{array}{c}20 * \\
1934\end{array} \mid$ & $\mid \begin{array}{c}17 \\
(1934)\end{array}$ & $\mid \begin{array}{c}15 \\
(1934)\end{array}$ & $\left.\begin{array}{c}13 \\
1934\end{array}\right)$ & $\begin{array}{c}13 \\
(1937) \\
\end{array}$ & $\left|\begin{array}{c}13 \\
(1938)\end{array}\right|$ & $\begin{array}{c}11 \\
(1934) \\
\end{array}$ & $\begin{array}{c}77 \\
(1938) \\
\end{array}$ & $\begin{array}{c}77 \\
(1939)\end{array}$ & $\begin{array}{c}78 \\
(1937) \\
\end{array}$ & $\begin{array}{c}9 \\
(1938)\end{array} \mid$ & $\begin{array}{c}5 \\
(1938)\end{array}$ & $\begin{array}{c}11 / \text { Sept. } \\
(1934)\end{array}$ & $\begin{array}{c}13 / \text { Dec. } \\
(1934)\end{array}$ & \begin{tabular}{|c|}
$\mathrm{F} 2$ \\
$(1934)$
\end{tabular} & A & B & $\mathrm{c}$ & $\left|\begin{array}{c}\text { near } \\
\text { Nizizima } \\
(1934)\end{array}\right|$ & \begin{tabular}{c|}
2 \\
$(1938)$
\end{tabular} & \begin{tabular}{|c|}
5 \\
$(1939)$
\end{tabular} & $\left|\begin{array}{c}7 \\
(1938)\end{array}\right|$ & $\left.\mid \begin{array}{c}18 \\
(1939)\end{array}\right)$ & $\left|\begin{array}{c}23 \\
1938\end{array}\right|$ & $\left|\begin{array}{c}10 \\
(1939)\end{array}\right|$ & $\left|\begin{array}{c}29 \\
(1938)\end{array}\right|$ & $\begin{array}{r}21 \\
8 / V I \\
(1939\end{array}$ \\
\hline Pyrosoma atlanticum atlanticum & & & & & & & & & & & - & 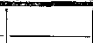 & 4 & & & 1 & & & & & & & & & & & \\
\hline $\begin{array}{l}\text { Pyrosoma atlanticum atlanticum } \\
\text { Larval or small colonies }\end{array}$ & & & & & & & 17 & & & & & & $\mathrm{CC}$ & $\mathrm{C}$ & $\mathrm{CC}$ & & 29 & 2 & $\mathrm{C}$ & & & 15 & & & 1 & & \\
\hline Pyrosoma agassizi & & & & & & & & & & & & & & & & & & & & & & & & & & & \\
\hline Cyclosalpa pinnata & & & & & & & {[} & & & & g. 1 & & & & - & & & & & & & & & & & & \\
\hline $\begin{array}{l}\text { Cyclosalpa foridana } \\
\text { Brooksia rostrata }\end{array}$ & & & & & & & & & & & & C. & & & - & $\ldots$ & & & & 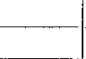 & & & & & & - & \\
\hline Metcalfina hexagona & & & & & & & & & & & & & & & 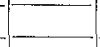 & & & & & & & & & & & G & \\
\hline Salpa maxima & & & & & & & & & & & & g. 19 & & & & & & & & & & & & & & & \\
\hline Salpa fusiformis & & & g. 11 & & & \begin{tabular}{|l|} 
s. 2 \\
g. $34 *$ \\
\end{tabular} & $\begin{array}{ll}\text { s. } 1 \\
\text { g. } 6\end{array}$ & g. $70 *$ & & & g. 10 & & & & g. 2 & & & & & & & $\begin{array}{l}\text { s. } 25 \\
\text { g. } 38 * \\
\end{array}$ & & & & $\begin{array}{l}\text { s. } 6 \\
\text { g. } 1 \\
\end{array}$ & $\begin{array}{l}\text { s. } 7 \\
\text { g. } 3\end{array}$ \\
\hline $\begin{array}{l}\text { Salpa fusiformis } \\
\text { f. aspera }\end{array}$ & 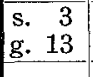 & & & & & & & & & & & s. 2 & & & & & & & & & & & & $\begin{array}{l}\text { S. } 8 \\
\text { g. } 4 \\
\end{array}$ & & & \\
\hline Salpa cylindrica & & & & & & & & & & & & & & & & & & & & & & & & & & & \\
\hline Iasis zonaria & & & & & & & g. 1 & & & & & g. 8 & g. 3 & & & & & & & & & & & & & g. 2 & g. 1 \\
\hline Thetys vagina & & & & & & & & & $\begin{array}{ll}\text { s. } 1 \\
\text { g. C }\end{array}$ & & & & & & & & & & & & & & & & & & \\
\hline Thatia democratica & & & & s. 1 & & & $\begin{array}{l}\text { S. } 4 \\
\text { g. } 7 \\
\end{array}$ & $\begin{array}{l}\text { s. } 5 \\
\text { g. } 9 \\
\end{array}$ & & $\begin{array}{r}\text { s. } 9 \\
\text { g. } 14 \\
\end{array}$ & s. 2 & & $\begin{array}{l}\text { s. } 2 \\
\text { g. } 2\end{array}$ & $\begin{array}{l}\text { s. } 6 \\
\text { g. } 8 \\
\end{array}$ & $\begin{array}{l}\text { s. } 10 \\
\text { g. } 17 \\
\end{array}$ & s. 1 & g. 2 & $\begin{array}{l}\text { s. } 1 \\
\text { g. } 6 \\
\end{array}$ & $\begin{array}{l}\text { s. } 2 \\
\text { g. } 1 \\
\end{array}$ & & & g. 1 & $\begin{array}{l}\text { S. } 1 \\
\text { g. } 2 \\
\end{array}$ & & $\begin{array}{l}\text { s. C } \\
\text { g. C } \\
\end{array}$ & & $\begin{array}{l}\text { s. } 2 \\
\text { g. } 1\end{array}$ \\
\hline Pegea confoederata & 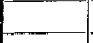 & & & & & & & & & & & & & & & & & & & & & & & & & & \\
\hline Traustedtia multitentaculata & & & & & & & & & & & & & & & & & & & & & & & & & & & \\
\hline Doliolum denticulatum & & & & & & & 2 & & & & & & 6 & & 5 & 2 & 7 & 11 & 8 & & 21. & & & & & & 1 \\
\hline Doliolum nationalis & & & & & 4 & & & & & 14 & & 2 & 1 & & & & & & & & & & & & 1 & & \\
\hline $\begin{array}{l}\text { Dolioletta gegenbauri var. } \\
\text { tritonis }\end{array}$ & & & & & 11 & & 13 & 2 & & 6 & & & & & & & & 1 & & 4 & & & & & & & \\
\hline Doliolid Amme & & & 1 & & 5 & & 4 & & 3 & 23 & 2 & 2 & & & 1 & 3 & & 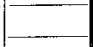 & & 1 & & 3. & & & & & \\
\hline $\begin{array}{l}\text { Doliolids, damaged individuals } \\
\text { or juv. }\end{array}$ & & & & + & & & & & & & & & & & & & & & & & & & & & & & \\
\hline Oik. longicauda & & 2 & 1 & 4 & 6 & & 26 & & & 6 & & 1 & 12 & & 42 & $\frac{7}{00}$ & 4 & 18 & 10 & 5 & & 1 & & & & & \\
\hline Oik. fusiformis & & & & & & & 1 & & & & & & & & & 22 & 1 & & 10 & & & & & & & & \\
\hline Oik. rufescens & & & & & 4 & 1 & 11 & & 1 & 51 & & & 5 & & & 1 & & & 2 & 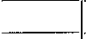 & 1 & 1 & & & & & \\
\hline Oik. parva* & & - & & & & & & & & & & & & & & 1 & & & & & & & & & & & \\
\hline Oik. cophocerca & & & & & & & & & & & & & & & & & & & & 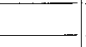 & & 1 & & & & & \\
\hline Oik. albicans & & & & & & & & 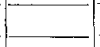 & & & & - & 1. & & & & & - & 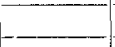 & & & & & & & & 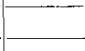 \\
\hline Oik. labradoriensis & & 2 & & & & & & & & & & 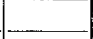 & & & 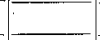 & & & & & $\ldots$ & & & & & & & \\
\hline $\begin{array}{l}\text { Oikoplearara spp. } \\
\text { Damaged specimens or juv. }\end{array}$ & & & & & & & & & 4 & 1 & & & & & & & & & & 1 & & & & 1 & & & \\
\hline Meg. huxleyi & & & & & & & $-\overline{3}$ & & & 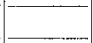 & 4 & 8 & & & & & & & & & & & & & & & 3 \\
\hline $\begin{array}{l}\text { Steg. magnum } \\
\text { Fritio boralis f. sarrassi }\end{array}$ & & & & & & & & & & 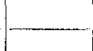 & & & & & & & & - & 2 & & & & & & & & \\
\hline
\end{tabular}

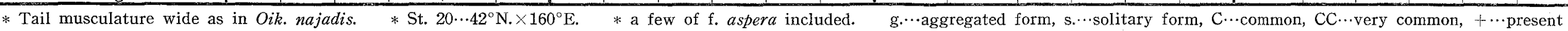

Appendix Table 19-1. Pelagic tunicates collected by the Sôyô-maru in the neighbouring waters of Japan. 
F.O........Frequency of Occurrèncè

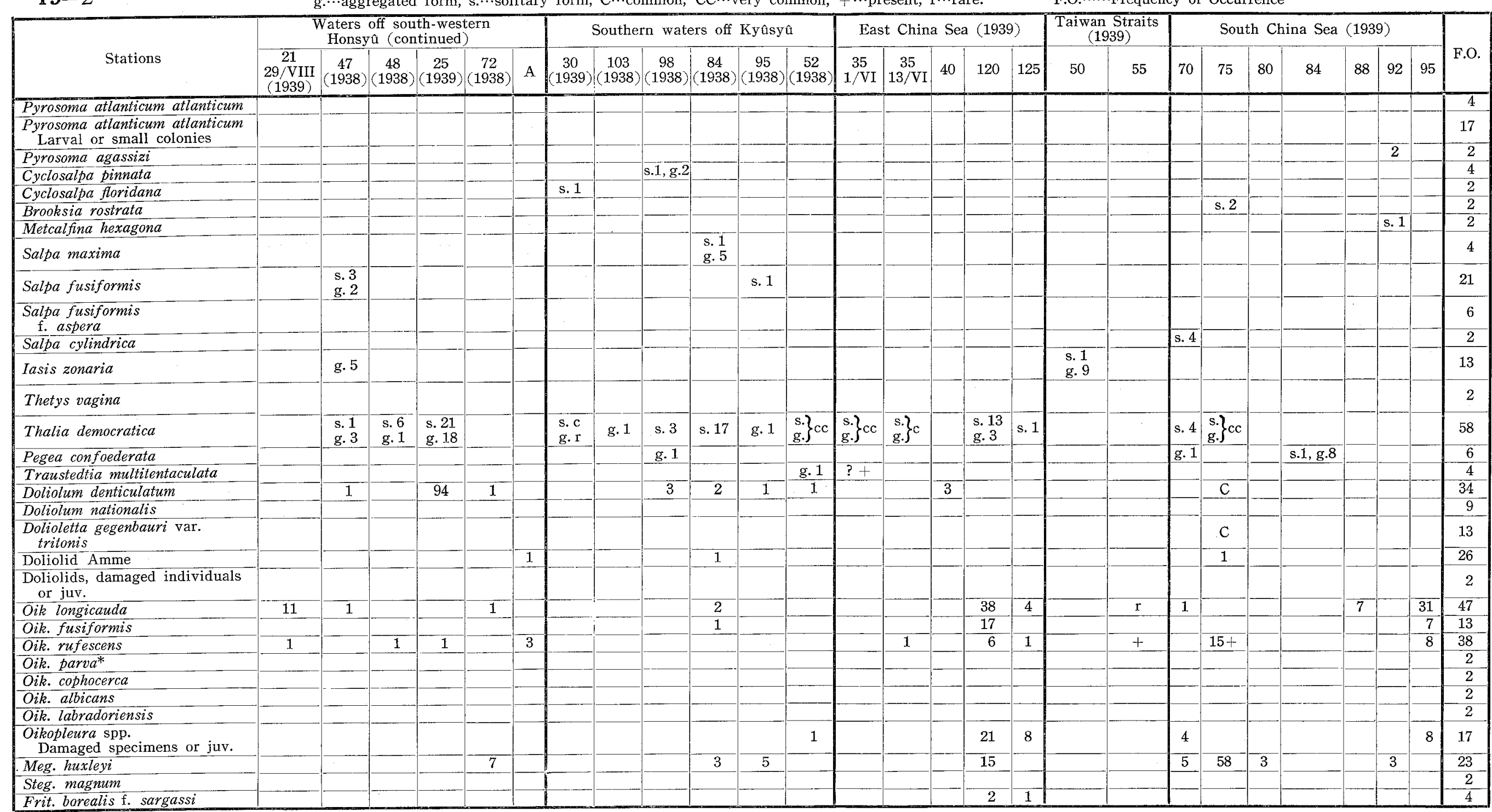

* Tail musculature wide as in Oik. najadis.

Appendix Table 19-2. Pelagic tunicates collected by the Sôyo-maru in the neighbouring waters of Japan. 